\title{
Análise in silico de regiões promotoras de genes de Xylella fastidiosa
}

\author{
FERNANDO DOMINGUES KÜMMEL TRIA
}

Dissertação apresentada ao Instituto de Matemática e Estatística da Universidade de São Paulo para obtenção do Título de Mestre em Ciências.

Programa: Interunidades em Bioinformática Instituição: Universidade de São Paulo Orientação: Prof ${ }^{\mathrm{a}}$. Dr ${ }^{\mathrm{a}}$. Aline Maria da Silva

O autor deste trabalho foi contemplado com auxílio financeiro da FAPESP e CAPES 



\section{Análise in silico de regiões promotoras de genes de Xylella fastidiosa}

Este exemplar corresponde à versão corrigida da dissertação de mestrado apresentada por Fernando Domingues Kümmel Tria à comissão julgadora do programa de Pós-Graduação Interunidades em Bioinformática da Universidade de São Paulo.

Comissão julgadora:

Prof $^{a}$. Dr ${ }^{\mathrm{a}}$. Aline Maria da Silva - IQ - USP

Prof. Dr. João Carlos Setubal - IQ - USP

Prof. Dr. José Miguel Ortega - ICB - UFMG 

"If the doors of perception were cleansed everything would appear to man as it is: infinite." William Blake 

Aos meus queridos pais, Paulo e Hozana, e ao meu irmão Tiago. 



\section{Agradecimentos}

Agora com meus estudos de mestrado finalizados existem algumas pessoas para as quais eu não poderia deixar de mencionar minha profunda gratidão.

Gostaria de agradecer à professora Aline por ter aceitado o desafio de me receber como seu aluno, mesmo diante de minha transparente inexperiência; pela sua dedicada tutoria, em assuntos científicos e do cotidiano, que ao mesmo tempo me tranquilizou e me incentivou a alcançar meus objetivos de maneira plena; e por proporcionar um ambiente de trabalho tão agradável que sob sua sábia administração me fez sentir em casa ao longo dessa experiência impossível de se atribuir um valor justo. Muito obrigado!

Sou imensamente agradecido ao que eu considero o tripé da minha vida: meus pais, Paulo e Hozana, e meu irmão Tiago. Mesmo sob fogo pesado das minhas incertezas, devaneios e por vezes rebeldia inconsciente, o suporte e amor incondicional dos três me mantêm estável nas situações mais difíceis. As recordações de nossos momentos juntos, como as reuniões nos finais de semana, e a expectativa dos que estão por vir são ao mesmo tempo minha fonte de felicidade e energia para superar limites. Espero algum dia poder retribuir a altura aos seus esforços que fizeram germinar em mim princípios aos quais serei sempre fiel e grato.

Agradeço ao grupo da professora Aline. Aos veteranos Paulo Zaini, Wesley Santana, Paulo Pierry e Oséias Junior, que pacientemente contribuíram para minha inserção na ciência e formação do pensamento crítico através de discussões e "tira dúvidas" sobre os universos "Xylella" e "Ciência". Aos que na época eram (juntos comigo) os calouros do laboratório, Gustavo Chaves e Rodrigo Duarte, pelo apoio, conversas e companhia em comemorações e lazer. Aos que entraram em seguida, Ana Paula, Luciana Principal, Deibs Barbosa e Joaquim Martins pela convivência agradável. Ao técnico do laboratório Alexandre Sanchez pela sua eterna paciência em orientar, sua pró-atividade para resolver problemas das mais variadas naturezas e por estabelecer o bom funcionamento do laboratório. A todos eles agradeço pela amizade, companhia nas atividades do dia-a-dia e também pelos bate-papos dos mais variados temas, irreverentes e interessantes, que propiciaram um ambiente de trabalho aconchegante e enriquecedor.

Agradeço ao professor Alan Durham e a seu grupo por terem me acolhido como membro e contribuído com discussões de extremo valor para o desenvolvimento do presente projeto e para minha formação científica. Da mesma forma agradeço ao programa de bioinformática e a todos docentes e funcionários da comunidade USP, que juntos tornaram possível esta realização.

Agradeço também aos amigos e familiares que, para não correr o risco de cometer injustiça, não serão citados individualmente, mas que são igualmente importantes tanto pelo apoio que me concederam nos momentos difíceis como pelo companheirismo nos momentos de felicidade.

Agradeço às agências de fomento, CAPES e FAPESP, pelo apoio financeiro. O autor deste trabalho foi contemplado com uma bolsa de mestrado concedida pela FAPESP. 


\section{Resumo}

Xylella fastidiosa é uma bactéria gram-negativa, não flagelada, agente causal de doenças de importância econômica como a doença de Pierce nas videiras e a clorose variegada dos citros (CVC) nas laranjeiras. O objetivo do presente trabalho foi realizar análises in silico das sequências promotoras dos genes deste fitopatógeno em uma tentativa de arrecadar novas evidências para o melhor entendimento da dinâmica de regulação transcricional de seus genes, incluindo aqueles envolvidos em mecanismos de patogenicidade e virulência. Para tanto, duas estratégias foram utilizadas para predição de elementos cis-regulatórios em regiões promotoras do genoma da cepa referência 9a5c, comprovadamente associada à CVC. A primeira, conhecida como phylogenetic footprinting, foi empregada para identificação de elementos regulatórios conservados em promotores de unidades transcricionais ortólogas, levando em consideração o conjunto de genes de $X$. fastidiosa e 7 espécies comparativas. $O$ critério para identificação de unidades transcricionais ortólogas, isto é, unidades trancricionais oriundas de espécies distintas e cujos promotores compartilham elementos cisregulatórios, foi paralelamente estudado utilizando-se informações regulatórias das bactérias modelos: Pseudomonas aeruginosa, Bacillus subtilis e Escherichia coli. Os resultados obtidos com análise de phylogenetic footprinting nos permitiu acessar a rede regulatória transcricional da espécie de forma compreensiva (global). Foram estabelecidas 2990 interações regulatórias, compreendendo 80 motivos distribuídos nos promotores de $56.8 \%$ das unidades transcricionais do genoma de $X$. fastidiosa. Na segunda estratégia recuperamos informações regulatórias experimentalmente validadas em $E$. coli e complementamos o conhecimento de dez regulons de $X$. fastidiosa, através de uma metodologia de scanning (varredura), dos quais algumas interações regulatórias já haviam sido previamente descritas por outros trabalhos. Destacamos os regulons de Fur e CRP, reguladores transcricionais globais, que se mostraram responsáveis pela modulação de genes relacionados a mecanismos de invasão e colonização do hospedeiro vegetal entre outros. Por fim, análises comparativas em regiões regulatórias correspondentes entre cepas foram realizadas e diferenças possivelmente associadas a particularidades fenotípicas foram identificadas entre 9a5c e J1a12, um isolado de citros não virulento, e 9a5c e Temecula1, um isolado de videira causador da doença de Pierce.

Palavras-chave: predição in silico de elementos cis-regulatórios, Clorose Variegada do Citros, doença de Pierce, fitopatógeno, motivos regulatórios, promotores, sítios de ligação de fatores transcricionais, regulon, Xylella fastidiosa. 


\section{Abstract}

Xylella fastidiosa is a gram-negative, non-flagellated bacterium responsible for causing economically important diseases such as Pierce's disease in grapevines and Citrus Variegated Clorosis (CVC) in sweet orange trees. In the present work we performed in silico analysis on promoter sequences of protein-coding genes from this phytopathogen, including those involved in virulence and pathogenic mechanisms, in an attempt to better understand the underlying transcriptional regulatory dynamics. Two strategies for cis-regulatory elements prediction were applied on promoter sequences from 9a5c strain genome, a proven causal agent of CVC. The first one, known as phylogenetic footprinting, involved the prediction of regulatory motifs conserved on promoter sequences of orthologous transcription units from $X$. fastidiosa and a set of 7 comparatives species. The criteria to identify orthologous transcription units, i. e., those from different species and whose promoter sequences share at least one common regulatory motif, was studied based on regulatory information available for model organisms: Pseudomonas aeruginosa, Bacillus subtilis and Escherichia coli. The results obtained with the phylogenetic footprinting analysis permitted us to access the underlying transcriptional regulatory network from the species in a comprehensive manner (genome-wide), with a total of 2990 regulatory interactions corresponding to 80 predicted motifs distributed on promoter sequences of $56.8 \%$ of all transcription units. In the second strategy regulatory information from $E$. coli was recovered and used to expand the knowledge of ten regulons in $X$. fastidiosa, through a scanning process, of which some regulatory interactions were previously described by independent studies. We emphasize some genes related to host invasion and colonization present in the Fur and CRP regulons, two global transcription regulators. Lastly, comparative analysis on corresponding regulatory regions among strains were performed and differences possibly associated to phenotypic variation were identified between $9 \mathrm{a} 5 \mathrm{c}$ and $\mathrm{J1a} 12$, a non-virulent strain isolated from orange trees, and between 9a5c and Temecula1, a strain associated to Pierce's disease on grapevines.

Keywords: in silico prediction of cis-regulatory elements, Citrus Variegated Chlorosis, Pierce's Disease, plant pathogen, regulatory motifs, promoters, transcription factor binding sites (TFBS), regulon, Xylella fastidiosa. 


\section{Sumário}

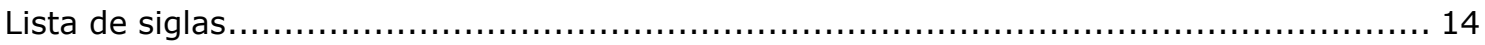

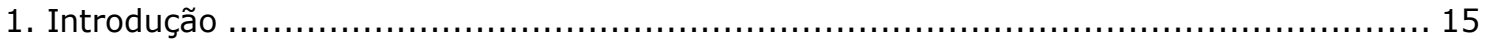

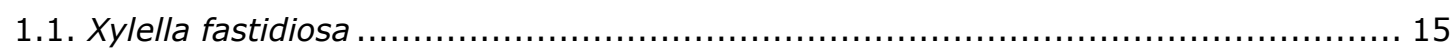

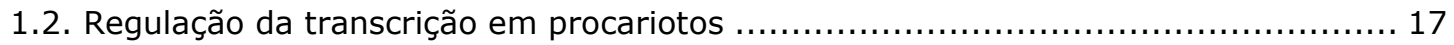

1.3. Regulação da transcrição e elementos cis-regulatórios em Xylella fastidiosa ............ 18

1.4. Métodos computacionais para predição de elementos cis-regulatórios - TFBSs ......... 23

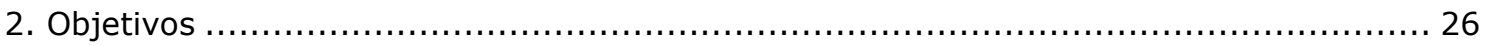

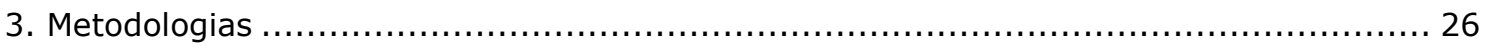

3.1. Definição de clusters gênicos - genes ortólogos ........................................... 26

3.2. Inferência de TFBSs a partir de informações de regulação transcricional da bactéria

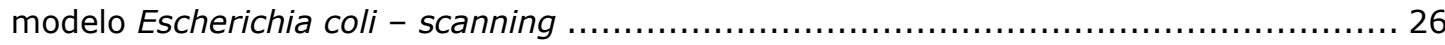

3.3. Inferência ab initio de motivos regulatórios - phylogenetic footprinting ................. 28

3.3.1. Critério para identificação de unidades transcricionais ortólogas .................... 31

3.3.2. Acessando a consistência dos regulons ............................................... 33

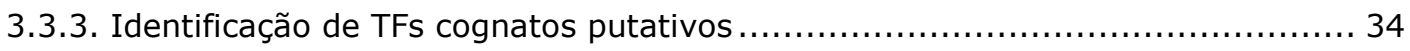

3.4. Análises comparativas entre cepas de Xylella fastidiosa ................................... 35

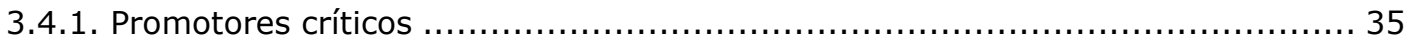

3.4.2. Distribuição de motivos regulatórios em diferentes genomas de Xylella fastidiosa

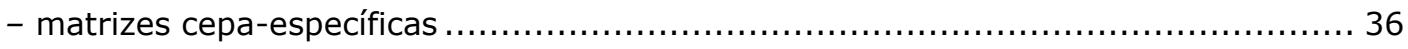

3.4.3. Análises filogenéticas baseadas em motivos regulatórios .......................... 37

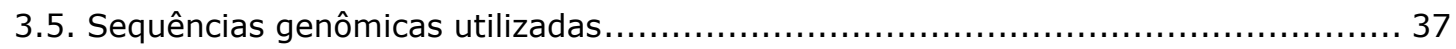

3.5.1. Análise comparativa entre cepas de Xylella fastidiosa ................................ 38

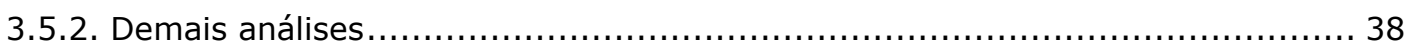

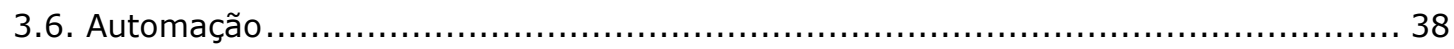

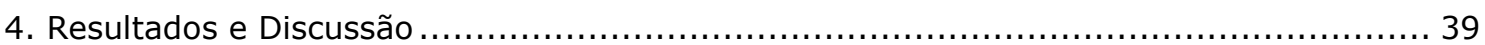

4.1. Inferência de TFBSs a partir de informações de regulação transcricional da bactéria modelo Escherichia coli - scanning ................................................................ 39

4.2. Inferência ab initio de motivos regulatórios - phylogenetic footprinting................ 47

4.2.1 Critério para identificação de unidades transcricionais ortólogas .................... 47

4.2.2 Motivos regulatórios preditos - regulons ab initio .................................... 54

4.3. Análises comparativas entre cepas de Xylella fastidiosa ................................... 63

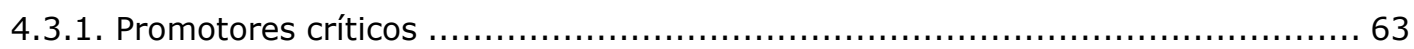

4.3.2. Distribuição de motivos regulatórios em diferentes genomas de Xylella fastidiosa

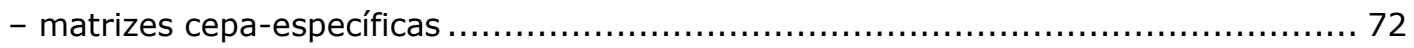

4.3.3. Análises filogenéticas baseadas em motivos regulatórios ........................ 74

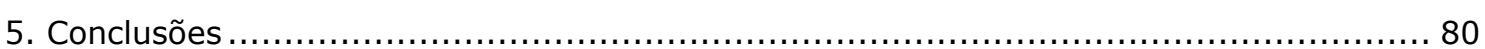

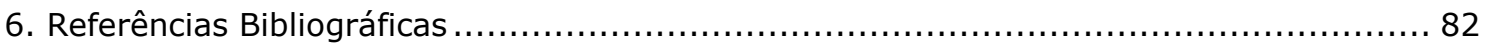

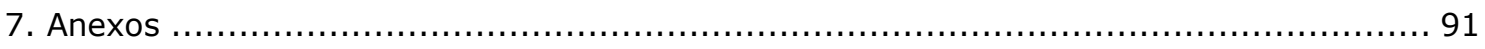

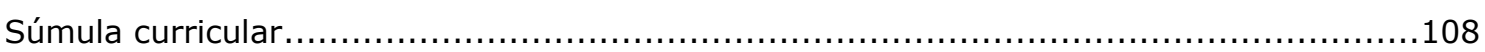





\section{Lista de siglas}

TU Unidade de transcrição

TF Fator transcricional

TFBS Sítio de ligação do fator transcricional

BLAST Basic Local Alignment Search Tool

IMG-ER Integrated Microbial Genomes - Expert Review

DOE Departament of Energy

JGI Joint Genome Institute

CVC Clorose Variegada dos Citros

DNA Ácido desoxirribonucleico

RNA Ácido ribonucleico

RNAP RNA polimerase

mRNA RNA mensageiro

sRNA pequeno RNA não codificante (small RNA)

PWM Position Weight Matrix

GS Grau de similaridade 


\section{Introdução}

\subsection{Xylella fastidiosa}

Xylella fastidiosa é uma bactéria Gram-negativa, não-flagelada, que coloniza o xilema de diversas espécies vegetais e é transmitida às plantas hospedeiras por insetos vetores da família Cicadellidae e Cercopidae, popularmente conhecidos como cigarrinhas. Estes insetos se alimentam do fluído que percorre o xilema da planta e são infectados ao se alimentarem da seiva de plantas contaminadas. As bactérias ficam restritas à parte anterior do intestino do inseto, aderidas ao forro cuticular do cibário, sendo transmitidas para plantas sadias em alimentações subsequentes. No hospedeiro vegetal, $X$. fastidiosa forma um biofilme compacto, que eventualmente ocasiona oclusão dos vasos do xilema (Purcell e Hopkins, 1996; Hopkins e Purcell, 2002; Alves et al., 2003; Newman et al., 2003; Redak et al., 2004; Almeida et al., 2005; Chatterjee et al., 2008).

O gênero Xylella é composto por uma única espécie, Xylella fastidiosa, e faz parte da família Xanthomonadaceae, a qual inclui também os gêneros Xanthomonas e Stenotrophomonas (de Mello Varani et al., 2009; Pieretti et al., 2009). A família Xanthomonadaceae pertence à subdivisão gama das proteobactérias, que é modelo em diversificação bacteriana, incluindo espécies comensais e de vida-livre, simbiontes intracelulares e patógenos de plantas e animais (Woese, 1987; Lerat et al., 2005). Análises filogenéticas possibilitaram o agrupamento de isolados de $X$. fastidiosa em cinco subespécies, associadas a diferentes hospedeiros: piercei (videira), sandyi (espirradeira), multiplex (amendoeiras e outras plantas), pauca (citrus, cafeeiro, ameixeira e hibisco) e tashke (chitalpa tree) (Rodrigues et al., 2003; Schaad et al., 2004; Schuenzel et al., 2005; Randall et al., 2009).

Em algumas espécies de plantas, $x$. fastidiosa existe como uma bactéria endofítica aparentemente inofensiva enquanto que nos hospedeiros suscetíveis, sua proliferação no xilema resulta em sintomas que incluem clorose, lesões necróticas nas folhas, nanismo, deterioração dos galhos, frutos não-aproveitáveis, e, eventualmente, morte da planta. Os sintomas causados por este fitopatógeno parecem estar relacionados aos estresses hídrico e/ou nutricional, decorrentes da oclusão do xilema (Purcell e Hopkins, 1996; Hopkins e Purcell, 2002; Chatterjee et al., 2008), e com a resposta sistêmica do hospedeiro suscetível à interação com o patógeno (Jones e Dangl, 2006; Gambetta et al., 2007; Lin et al., 2007; Purcino et al., 2007; Silva-Stenico et al., 2009).

Diversos genes codificadores de efetores de patogenicidade são reconhecidos no genoma de $X$. fastidiosa, entre eles estão os genes envolvidos na formação de biofilme bacteriano, em que uma matriz complexa é formada em consequência da aglutinação celular, tais como aqueles codificadores de adesinas fimbriais, afimbriais e exopolissacarídeos (Dow e Daniels, 2000; Chatterjee et al., 2008). O maquinário do sistema de secreção do tipo II por sua vez é responsável pela exportação de enzimas celulolíticas (endocelulases e exocelulases) e pectinolíticas (poligalacturonase), que permitem a degradação da parede celular vegetal para aquisição de carbono e, consequentemente, facilitam a dispersão do 
fitopatógeno dentro dos vasos xilemáticos das plantas (Lambais et al., 2000; Chatterjee et al., 2008; Perez-Donoso et al., 2010). A motilidade celular, realizada pelo mecanismo de twitching motility, e a adesão celular (célula-célula e célula-superfície) são desempenhadas pelos pili longo do tipo IV e o pili curto do tipo I, respectivamente. Embora ambas as estruturas também estejam envolvidas na formação de biofilme elas contribuem de forma antagônica para motilidade e adesão e são reconhecidas como importantes fatores de patogenicidade, ora contribuindo para a colonização sistêmica do hospedeiro ora contribuindo para a oclusão de vasos xilemáticos e, portanto, para o estresse hídrico e/ou nutricional da planta (Meng et al., 2005; De La Fuente et al., 2007a; De La Fuente et al., 2007b; Galvani et al., 2007; Li et al., 2007). Sistemas de toxinas e anti-toxinas (bacteriocinas e colicinas $\mathrm{V}$, por exemplo), codificadas no genoma de $X$. fastidiosa, são supostamente responsáveis por conferir maior competitividade em relação a células susceptíveis (Simpson et al., 2000; Riley e Wertz, 2002; Chatterjee et al., 2008).

Entre as doenças associadas à infecção por $X$. fastidiosa, estão a doença de Pierce (PD) das videiras, a escaldadura foliar de amendoeiras (almond leaf scorch, ALS), a escaldadura foliar do cafeeiro ou requeima do café (cofee leaf scorch, CLS), a escaldadura foliar de ameixeiras (plum leaf scald, PLS) e a clorose variegada dos citros (CVC), popularmente conhecida como amarelinho (Purcell e Saunders, 1999; Purcell et al., 1999; Hopkins e Purcell, 2002).

Após o trabalho pioneiro de sequenciamento e anotação do genoma da cepa 9a5c de $X$. fastidiosa (Simpson et al., 2000) a qual foi isolada de laranjeiras e comprovadamente associada à CVC (Li et al., 1999), genomas de outros 7 isolados/cepas foram completa ou parcialmente sequenciados: cepas Temecula-1 e GB514, isoladas de videiras e agentes da doença de Pierce; cepas Dixon, M12 e M23, associadas à escaldadura da amendoeira, cepa Ann-1 agente causal da escaldadura da espirradeira e cepa EB92-1, isolada de sabugueiro do Canadá e utilizada como cepa de bio-controle (Simpson et al., 2000; Bhattacharyya et al., 2002a; Bhattacharyya et al., 2002b; Van Sluys et al., 2003; Chen et al., 2010; Zhang et al., 2011).

$X$. fastidiosa pertence a um grupo de organismos com genomas de tamanho relativamente pequeno e pode-se observar que os prováveis eventos de deleção genômica parecem ter sido mais abundantes do que os eventos de ganho por duplicação ou transferência lateral, ainda que muitas sequências de fagos tenham se inserido em seu genoma (Van Sluys et al., 2003; de Mello Varani et al., 2008; de Mello Varani et al., 2009; Pieretti et al., 2009). A ausência de genes e vias importantes nesta espécie, decorrente desta evolução convergente de redução de seu genoma, provavelmente foi favorecida pela adaptação destas bactérias ao crescimento no restrito ambiente do xilema e a dependência de um vetor animal para sua propagação (Van Sluys et al., 2002; Chatterjee et al., 2008; Pieretti et al., 2009). 


\subsection{Regulação da transcrição em procariotos}

O processo de expressão gênica nos organismos está submetido a um complexo e rigoroso controle, que pode ocorrer em qualquer etapa envolvida na síntese do produto gênico funcional. No entanto, a transcrição do DNA em RNA é considerada o ponto principal e mais importante para o controle da expressão gênica, particularmente em procariotos.

Para o reconhecimento de promotores e pré-início da transcrição, a RNA polimerase (RNAP) bacteriana requer associação com uma subunidade sigma. Assim, durante o préinício da transcrição a holoenzima RNAP liga-se a elementos conservados localizados a montante do início de transcrição, os quais são reconhecidos especificamente por distintos fatores sigma. Um genoma bacteriano codifica diferentes fatores sigma, os quais são utilizados na resposta transcricional guiando a RNAP para conjuntos específicos de genes. A família dos $\sigma^{70}$ inclui fatores associados à expressão de genes de manutenção (housekeeping genes) relacionados ao crescimento celular, enquanto que fatores sigma alternativos (ex: $\sigma^{54}$ ) regulam a expressão de conjuntos de genes com funções mais especializadas (Gruber e Gross, 2003; van Hijum et al., 2009).

A arquitetura de promotores procarióticos contempla, além do sítio de início da transcrição propriamente dito e de regiões reconhecidas pelos fatores sigma (regiões -10 e 35), elementos cis-regulatórios tais como UP (upstream element) e sítios de interação com fatores transcricionais (TFBS, Transcription Factor Binding Site). TFBSs são elementos que podem apresentar diversos tamanhos e diferentes localizações no genoma. Em procariotos eles geralmente se localizam entre as posições -90 a +60 referente ao sítio de início de transcrição, seus tamanhos variam de 12 a 30 pares de bases e frequentemente apresentam simetria direta ou palindrômica. Estes elementos são reconhecidos por proteínas regulatórias, os fatores transcricionais (TFs, Transcription Factors), que são capazes de ativar ou reprimir a expressão gênica (van Hijum et al., 2009). Em suma, os TFs reconhecem sequências específicas no DNA e são responsáveis por promover ou impedir o recrutamento da RNA polimerase e/ou outros elementos do aparato de transcrição (Browning e Busby, 2004).

Os TFBSs são ditos degenerados, pois podem apresentar variações nas suas sequências sem, no entanto, perder suas funções. Desta forma, apesar de um TF apresentar afinidade ótima por uma dada sequência ele continua sendo capaz de reconhecer e interagir com regiões que apresentam algumas variações na composição de bases (Bulyk, 2003). A degeneração dos TFBSs parece ter uma importante funcionalidade biológica, tendo em vista que a maioria dos TFs regula dois ou mais genes e que a necessidade da célula pode requisitar que diferentes genes tenham taxas de transcrição distintas. Portanto, variar a afinidade de um TFBS pelo seu respectivo TF, através de variações na composição da sequência, é uma maneira de modular adequadamente estas taxas ao mesmo tempo em que possibilita o controle coordenado de diversos genes através de um mesmo TF (Stormo, 2000).

A organização dos genes bacterianos em operons também contribui para o controle transcricional coordenado de conjuntos de genes específicos. Cada operon é composto por 
um grupo de genes, que estão dispostos lado a lado na mesma fita de DNA e são transcritos como um único mRNA (Rodionov, 2007). Dessa forma, genes contidos em um mesmo operon dividem os mesmos elementos que regem o controle transcricional (Zhang et al., 2009). O conjunto de operons regulados por um mesmo TF forma o que se conhece como regulon (Rodionov, 2007).

Apesar da interação regulatória entre um TF e o conjunto de genes por ele afetado (regulon) ser geralmente atribuída, de forma simplificada, ao reconhecimento de elementos cis-regulatórios cognatos nas regiões promotoras dos genes, outros fatores também contribuem efetivamente para interação e merecem ser mencionados. São eles fatores epigenéticos como, por exemplo, o padrão de metilação do DNA nas regiões promotoras; a compactação do cromossomo e torções mediadas por proteínas específicas (nucleoidassociated proteins), que propiciam ou impedem o acesso do aparato transcricional ao promotor; e a cooperação sinergética entre módulos de TFs e a RNA polimerase que potencializam o sinal de transcrição a níveis ideais (Browning e Busby, 2004; Casadesus e Low, 2006; van Hijum et al., 2009; Browning et al., 2010; Dillon e Dorman, 2010). Além disso, a interação regulatória TF/TFBSs não deve ser compreendida como um evento fatalista de ocorrência ou não ocorrência, mas sim como um fenômeno termodinâmico cuja probabilidade de ocorrência é determinada por fatores biológicos e ambientais, para o qual sempre existe certo grau de incerteza ("ruído transcricional") (Maamar et al., 2007; Balleza et al., 2009; Silander et al., 2012).

\subsection{Regulação da transcrição e elementos cis-regulatórios em Xylella fastidiosa}

Os poucos elementos cis-regulatórios já identificados em $X$. fastidiosa são em sua maioria oriundos de análises computacionais seguida, em alguns casos, de validação experimental (Campoy et al., 2002; Gonzalez et al., 2005; Zaini et al., 2008; da Silva Neto et al., 2010; Novichkov et al., 2010a). Os dados existentes foram compilados (tabela 1) após o resgate das informações de artigos publicados e de dois bancos de dados de acesso público, específicos para tFBSs bacterianos, TractorDB (http://www.ccg.unam.mx/Computational_Genomics/tractorDB/) e RegPrecise (http://regprecise.lbl.gov/RegPrecise/).

Todos os sítios extraídos dos bancos Tractor DB e RegPrecise foram preditos computacionalmente, utilizando-se informações regulatórias de bactérias evolutivamente próximas à Xylella (Perez et al., 2007; Novichkov et al., 2010b), os quais ainda carecem de validação experimental. Este tipo de análise onde se transfere o conhecimento de informações regulatórias de uma espécie a outra é, por vezes, chamado de análise ortogonal.

Em (Zaini et al., 2008), dos 36 sítios de Fur preditos computacionalmente um foi validado por EMSA (electrophoretic mobility shift assay), o qual se localiza na região promotora do gene 15837201 (XF0599), codificador para um receptor de sideróforo que permite a captação de ferro do ambiente. A proteína Fur (ferric uptake repressor) é 
reconhecida por atuar como fator de transcrição de genes relacionados à homeostase de ferro em diversas espécies bacterianas (Ratledge e Dover, 2000; Carpenter et al., 2009).

Em (da Silva Neto et al., 2008; da Silva Neto et al., 2010), análises experimentais demonstraram um conjunto de genes afetados pelo fator $\sigma^{54}$, responsável pela modulação de genes envolvidos no metabolismo de nitrogênio entre outros (Buck et al., 2000). O gene 15838440 (XF1842), codificador da enzima glutamina sintetase, e 15839131 (XF2542), codificador para PilA uma proteína estrutural do pilus longo do tipo IV, tiveram os sítios reconhecidos por $\sigma^{54}$ mapeados.

Em (Campoy et al., 2002), os sítios regulatórios localizados computacionalmente foram testados experimentalmente e apenas dois genes se mostraram sob regulação de LexA, conhecido pela modulação de genes envolvidos na resposta SOS para o reparo a danos no DNA (Fernandez De Henestrosa et al., 2000), são eles: 15836727 (XF0122), codificador para o próprio TF LexA, e 15838904 (XF2313), codificador de uma DNA metilase.

Um sítio de ligação de BigR, um repressor associado a formação de biofilme (Barbosa e Benedetti, 2007), foi demonstrado experimentalmente no promotor do gene 15837370 (XF0768), codificador de uma hidrolase, e também no promotor do operon gum (XF0766 a XF0764), codificador de BigR e duas proteínas de membrana.

Em (da Silva Neto et al., 2007) um consenso de $\sigma^{\mathrm{E}}$, fator sigma extracitoplasmático, foi identificado alinhando-se promotores de genes dependentes deste fator que se mostrou responsável pela regulação de genes envolvidos em diversos processos tais como restrição e modificação de DNA; transdução de sinal; folding e degradação de proteínas. Tradicionalmente, os fatores sigma extracitoplasmáticos (ECF) se liberam de seu respectivos fatores anti-sigma (inibidores) em resposta a estímulos ambientais e influenciam a transcrição de genes alvo (Helmann, 2002).

Em (Koide et al., 2006) analisou-se a expressão gênica em larga escala em condições de choque térmico, nas quais genes de diversas funções foram diferencialmente expressos, incluindo chaperonas e enzimas responsáveis por metabolizar proteínas desnaturadas. Uma sequência consenso putativa foi determinada a partir do alinhamento de 6 promotores de genes induzidos.

É importante mencionar que a maioria dos trabalhos citados se utilizou da cepa 9a5c para condução das análises, com exceção dos trabalhos envolvidos na elucidação do regulon $\sigma^{54}$ (da Silva Neto et al., 2008; da Silva Neto et al., 2010), $\sigma^{\mathrm{E}}$ (da Silva Neto et al., 2007) e $\sigma^{32}$ (Koide et al., 2006), nos quais foi utilizada a cepa J1a12, também isolada de citros, porém não virulenta (Monteiro et al., 2001).

Estudos visando à análise de expressão gênica global e as consequências fenotípicas em diferentes condições experimentais, sem posterior identificação de motivos regulatórios, também estão disponíveis na literatura (Pashalidis et al., 2005; Shi et al., 2007; Killiny e Almeida, 2009; Shi et al., 2009). A ressaltar, análises de microarranjo realizadas a partir do cultivo de $9 a 5 c$ em diferentes concentrações de glicose identificaram a super-expressão, em altas concentrações de glicose, de genes codificadores de precursores fimbriais como PilY1, responsável pela locomoção por twitching motility, e colicinas $V$. Interessantemente, genes envolvidos na formação de biofilme não foram diferencialmente expressos em altas 
concentrações de glicose, como já havia sido observado em Xanthomonas campestris pv. campestris e Xanthomonas axonopodis pv. citri (Pashalidis et al., 2005). Em (Killiny e Almeida, 2009) um estudo de expressão gênica global conduzido com a cepa Temecula1, agente causador da doença de Pierce em videiras (Van Sluys et al., 2003), demonstrou a contribuição da adição de pectina no meio de cultura, um carbohidrato componente dos vasos do xilema, para o fenótipo de adesão celular mais acentuado. Além disso, foi notada a expressão diferencial de genes relacionados à infecção e patogenicidade em meios suplementado com diferentes combinações de fontes de carbono. Os resultados de (Killiny e Almeida, 2009) e (Pashalidis et al., 2005) indicam que os fenótipos antagônicos de adesão celular e motilidade em $X$. fastidiosa parecem ser diretamente influenciados pela disponibilidade de diferentes fontes de carbono. 
Tabela 1: Elementos cis-regulatórios em Xylella fastidiosa.

\begin{tabular}{|c|c|c|c|c|}
\hline $\begin{array}{c}\text { Fator } \\
\text { transcricional }\end{array}$ & $\begin{array}{c}\text { Sequência(s) } \\
\text { Regulatória(s) }\end{array}$ & $\begin{array}{c}\text { Origem (Genes ou grupo de } \\
\text { genes) }\end{array}$ & Abordagem & Fonte \\
\hline NagR & gATGACAACGgTaTCAaT & 15838062 & Computacional & RegPrecise \\
\hline NrdR & $\begin{array}{l}\text { cCcCatTATcTtGTGg (1) } \\
\text { tCACagcATtTtGTGT (2) }\end{array}$ & $\begin{array}{l}15837798(1) \\
15837798(2)\end{array}$ & Computacional & RegPrecise \\
\hline Zur & $\begin{array}{l}\text { tgAATGaTATAATATtACcTTaC (1) } \\
\text { GttATGTTATtTTATAACATaTt (2) }\end{array}$ & $\begin{array}{l}15836986(1) \\
15838687(2)\end{array}$ & Computacional & RegPrecise \\
\hline CRP & $\begin{array}{l}\text { tgttcAATTAAGTGATAGGAAACACAATCATaccgt (1) } \\
\text { gaaagAAATGCGTGGAAATGATCACATATTtgttt ( }(2) \\
\text { cctacAAAGACTTGATTTAAAGCACACTAAAaaact (3) } \\
\text { ctacaAAGACTTGATTTAAAGCACACTAAaaaac (4) } \\
\text { tagatAAAAATGCGACAAAAACCACGAAATAtccgc (5) } \\
\text { tgaatTIITTGTGATITATTCACGCATAAatcta (6) } \\
\text { gaattTITTGTGATITATTCACGCATAaatct (7) }\end{array}$ & $\begin{array}{l}15837825(1) \\
15838519(2) \\
15838775(3) \\
15838775(4) \\
15838775(5) \\
15838917(6) \\
15838917(7)\end{array}$ & Computacional & Tractor DB \\
\hline ArgR & agtttAAGTGATTAAAAATACGACGcattc & 15837600 & Computacional & Tractor DB \\
\hline Fur & gcggaTAGGATATTAGTAACGATTAATTTTGTaattg & 15836997 & Computacional & Tractor DB \\
\hline GcvA & ttcaaTTCATTTGTTATCATTCGAAattga & 15837060 & Computacional & Tractor DB \\
\hline PhoB & gcaatGTCACCGATTTGAAATAAAAATATCatttc & 15838732 & Computacional & Tractor DB \\
\hline TyrR & atacaGTGAATCAGTCAGTTCACcaaaa & 15838894 & Computacional & Tractor DB \\
\hline Fur & nnAATGATT/AATCAATAnnn & $\begin{array}{l}\text { Consenso proveniente de } 36 \text { sítios } \\
\text { preditos computacionalmente em } \\
\text { promotores degenes selecionados por } \\
\text { análises de microarranjos }\end{array}$ & Computacional & Zaini et al., 2008 \\
\hline LexA & TTAGtaatattACTAA (1) & $\begin{array}{c}15836727 \\
15838904(1) \\
\end{array}$ & Experimental & Campoy et al., 2002 \\
\hline$\sigma^{54}$ & TGGCACGGnnnnTTGCA/T & $\begin{array}{l}\text { Consenso proveniente do alinhamento } \\
\text { de promotores de genes, selecionados } \\
\text { por análises de expressão gênica }\end{array}$ & Computacional & da Silva Neto et al., 2010 \\
\hline BigR & CAATATATATTATTATATATTG & 15837370 & Experimental & Barbosa et al, 2007 \\
\hline
\end{tabular}




\begin{tabular}{|c|c|c|c|c|}
\hline$\sigma^{\mathrm{E}}$ & ${ }_{G} A A C n n-[N]_{16-17-G} T_{C} n n A$ & $\begin{array}{c}\text { Consenso proveniente do alinhamento } \\
\text { de promotores de genes, selecionados } \\
\text { por análises de expressão gênica }\end{array}$ & Computacional & da Silva Neto et al, 2007 \\
\hline$\sigma^{32}$ & CTTGAA-[N]9-14-CCNCACAT & $\begin{array}{c}\text { Consenso proveniente do alinhamento } \\
\text { de promotores de genes, selecionados } \\
\text { por análises de expressão gênica }\end{array}$ & Computacional & Koide et al, 2006 \\
\hline
\end{tabular}




\subsection{Métodos computacionais para predição de elementos cis-regulatórios - TFBSs}

A identificação de elementos cis-regulatórios é um desafio atual dos estudos de genômica de extrema importância para elucidação de redes regulatórias transcricionais. Ela pode ser realizada com a utilização de diversos algoritmos e métodos computacionais, os quais possibilitam, com variável grau de acurácia, a identificação de motivos que obedecem a características pré-determinadas (Tompa et al., 2005; GuhaThakurta, 2006; Janky et al., 2009; Shavkunov et al., 2009; van Hijum et al., 2009; Li et al., 2010). Os métodos computacionais podem ser divididos em dois grupos de acordo com a quantidade de informação a priori que se dispõe: os métodos ab initio e os métodos de scanning (MacIsaac e Fraenkel, 2006; Rodionov, 2007; van Hijum et al., 2009).

Os métodos de scanning se destinam à identificação de novos membros de regulons já conhecidos. Nestes casos dispõe-se de um conjunto de sequências sabidamente reconhecidas por um determinado $\mathrm{TF}$, as quais são alinhadas e utilizadas para determinar um modelo matemático representante do motivo regulatório. Este modelo é posteriormente empregado para a identificação de sítios adicionais (instâncias) possivelmente reconhecidos pelo TF em questão, utilizando-se ferramentas especializadas. Os métodos de scanning podem ser utilizados para transferir informações de regulons de uma espécie para outra ou para identificação de sítios adicionais na mesma espécie de onde as sequências regulatórias foram resgatadas (McGuire et al., 2000; Tan et al., 2001; Gonzalez et al., 2005; Novichkov et al., 2010b).

Os modelos matemáticos mais comuns utilizados para representação de motivos regulatórios são as sequências consenso e as PWMs (position weight matrix). As sequências consenso ou expressões regulares são basicamente um conjunto de caracteres (string) que representam os nucleotídeos A, C, T e G mais frequentes observados em cada posição do alinhamento de um conjunto de instâncias regulatórias reconhecidas por um mesmo TF. Quando utilizadas para predição de novas instâncias geralmente se aceita um determinado número de mismatches entre cada subsequência e o modelo, de modo a levar em consideração a degeneração inerente dos TFBSs. As PWMs são as formas mais comuns utilizadas para modelagem de motivos regulatórios, pois agregam informações quantitativas não capturadas com as sequências consenso, otimizando a especificidade e sensibilidade das predições de novas instâncias. Na prática, um motivo de tamanho $L$ pode ser representado por uma PWM de $4 \times \mathrm{L}$, em que as linhas correspondem aos 4 nucleotídeos possíveis e as colunas às.posições do motivo de tamanho L. Os elementos da matriz são pesos calculados a partir da frequência com que cada um dos 4 nucleotídeos são observados em cada posição do motivo, tendo como base um conjunto de instâncias de treinamento e também a distribuição de frequência dos nucleotídeos em um background. Uma das maneiras de se calcular os pesos da matriz (elementos) é mostrado na equação 1 , onde $f_{i, j}$ é a frequência do nucleotídeo $i$ na posição $j$ do motivo regulatório e $p_{i}$ é a probabilidade de se observar o nucleotídeo i no background (Stormo, 2000; Djordjevic et al., 2003; Pavesi et al., 2004; GuhaThakurta, 2006). 


$$
\log \frac{f i, j}{p i}
$$

Equação 1: Cálculo dos elementos de uma PWM. $\mathrm{f}_{\mathrm{i}, \mathrm{j}}$ : frequência do nucleotídeo i na posição $\mathrm{j}$ da cadeia. $\mathrm{p}_{\mathrm{i} \text { : }}$ probabilidade de se observar o nucleotídeo i no background.

Dado uma PWM é possível atribuir um log-odd score a qualquer sequência de tamanho L, calculado como a soma dos elementos da PWM correspondentes aos nucleotídeos de cada posição da sequência de tamanho $L$ avaliada. Sendo assim, assume-se que cada posição do motivo contribui de forma independente e aditiva para a interação TF/TFBS. O descritor das PWMs conhecido como information content (IC) é frequentemente utilizado para acessar o grau de degeneração do motivo, sendo que quanto maior o IC de uma PWM menor é a degeneração do motivo regulatório representado por ela (Stormo, 2000; Djordjevic et al., 2003; Pavesi et al., 2004; GuhaThakurta, 2006).

Os métodos $a b$ initio são direcionados para descoberta de motivos, quando não se tem nenhuma informação a priori da composição e localização das sequências regulatórias que se procura. Eles são tipicamente aplicados quando há evidência de co-regulação de um conjunto específico de genes, ou seja, genes cujos promotores provavelmente compartilham um ou mais elementos cis-regulatórios (Bulyk, 2003; GuhaThakurta, 2006; Rodionov, 2007; van Hijum et al., 2009). Estas evidências podem ser obtidas, por exemplo, através de resultados de análises de expressão gênica em larga escala utilizando-se microarranjos de DNA, sequenciamento de alto desempenho de cDNA (RNAseq) e/ou ChIP-on-chip (imunoprecipitação da cromatina seguida de análise com microarranjos de DNA) (Grainger et al., 2005; Gama-Castro et al., 2008; Shavkunov et al., 2009). Alternativamente, é possível utilizar um conjunto de genes envolvidos em uma mesma rota metabólica, para a qual existe forte evidência de regulação coordenada.

Após a identificação do conjunto de genes co-regulados, seus promotores são submetidos a análises que visam à identificação de subsequências super-representadas (possíveis motivos regulatórios) em relação ao universo de subsequências, através de ferramentas computacionais especializadas (Bailey, 1994; Hughes et al., 2000; Grainger et al., 2005; Tompa et al., 2005; Gama-Castro et al., 2008; Shavkunov et al., 2009; Zhang et al., 2009).

As ferramentas disponíveis para predição $a b$ initio podem ser classificadas de acordo com o tipo de algoritmo por elas empregado, enumerativos ou probabilísticos. Os algoritmos enumerativos, também chamados de algoritmos baseados em palavras (word-based) por se utilizarem de sequências consenso para modelagem dos motivos, fazem uma busca exaustiva no universo de subsequências de tamanho pré-determinado e têm a vantagem de obter a solução ótima para o problema. Em contrapartida são computacionalmente impraticáveis para a busca de motivos muito longos (Brazma et al., 1998; Pavesi et al., 2004; Sandve e Drablos, 2006; van Hijum et al., 2009).

Os algoritmos probabilísticos se utilizam de PWMs cujos parâmetros são estimados através de métodos heurísticos como Gibbs sampling e Expectation Maximization (EM), que 
buscam a convergência do IC da PWM. Apesar de serem computacionalmente mais eficientes para a identificação de motivos longos, em comparação aos enumerativos, não garantem a solução ótima para o problema (Brazma et al., 1998; Pavesi et al., 2004; van Hijum et al., 2009).

Estudos visando avaliar a performance de predição de diferentes ferramentas mostram que os resultados com elas obtidos são altamente influenciados pelas configurações utilizadas e a natureza do conjunto de dados em que são aplicadas, sendo difícil para o usuário determinar a priori a ferramenta e configuração mais adequada. Tendo em vista que as verdadeiras predições obtidas com ferramentas distintas são geralmente complementares entre si, aconselha-se o uso concomitante de mais de uma em análises de predição ab initio (Hu et al., 2005; Tompa et al., 2005; MacIsaac e Fraenkel, 2006).

Uma abordagem que se insere dentro dos métodos de predição $a b$ initio, mas que se destaca por não necessitar da identificação experimental de genes co-regulados é a que se conhece por phylogenetic footprinting. Esta abordagem identifica elementos conservados em promotores de genes ortólogos, baseando-se na premissa que elementos cis-regulatórios, da mesma forma que regiões codificantes, tendem a se conservar ao longo da evolução (McCue et al., 2001; Bulyk, 2003; Wasserman e Sandelin, 2004; Wels et al., 2006; Rodionov, 2007; van Hijum et al., 2009). Em suma, ela consiste na identificação de grupos ortólogos em múltiplas espécies seguida pela busca de elementos conservados nos promotores de genes presentes em um mesmo grupo. É importante ressaltar que o número de espécies envolvido na análise e as distâncias evolutivas que as separam são fatores cruciais para a obtenção de resultados acurados (McCue et al., 2002). Portanto, a disponibilidade em bancos de dados públicos de diversas sequências genômicas torna esta abordagem viável e especialmente interessante para análises genome-wide (global), quando o intuito é acessar a rede regulatória transcricional de uma espécie de forma compreensiva. Aliar resultados de análises de expressão gênica em larga escala com abordagens de phylogenetic footprinting tem sido comum para predição $a b$ initio de elementos cis-regulatórios em diversos organismos, pois permite filtrar motivos espúrios e auxilia na interpretação das predições (MacIsaac e Fraenkel, 2006; Rodionov, 2007; van Hijum et al., 2009).

Ao aplicarmos uma metodologia ab initio para predição de TFBSs em um genoma de interesse nos deparamos com uma restrição inerente à metodologia, em que diversos motivos são identificados, mas não sabemos a princípio os fatores transcricionais responsáveis por reconhecê-los.

Apesar de se tratar de um problema ainda sem uma solução computacional universal, a atribuição do par TF/TFBS pode ser feita por pelo menos duas estratégias. A primeira e talvez mais simples consiste em comparar motivos preditos com motivos caracterizados, ou seja, para os quais já se sabe os TFs reguladores (Wels et al., 2006; Liu et al., 2008; Fadda et al., 2009). A ferramenta TOMTOM (Bailey et al., 2009), desenvolvida para fazer alinhamentos entre matrizes representantes de motivos regulatórios, é uma das ferramentas disponíveis que pode ser utilizada para esta tarefa. A segunda estratégia se baseia na observação de que genes reguladores e genes regulados tendem a estar localizados próximos uns aos outros (Tan et al., 2005; Fadda et al., 2009). (Tan et al., 2005) observou em E. coli que verdadeiros pares de TFs/TFBSs (pares cognatos) tendem a estar 
significativamente mais próximos no genoma em relação a pares não verdadeiros (não cognatos). Esta informação pode ser utilizada para identificação de potenciais TFs para motivos preditos por estratégias ab initio, quando há disponível um conjunto de TFs/TFBSs de treinamento.

\section{Objetivos}

O objetivo deste projeto de Mestrado foi caracterizar, em escala global (genomewide), as sequências promotoras dos genes da bactéria Xylella fastidiosa em uma tentativa de arrecadar novas evidências que possam contribuir para o melhor entendimento da dinâmica de regulação transcricional dos genes deste fitopatógeno, incluindo aqueles envolvidos em mecanismos de patogenicidade e virulência. Para tanto, duas abordagens in silico independentes foram aplicadas para a identificação de potenciais elementos cisregulatórios, utilizando-se a sequência genômica da cepa 9a5c - comprovadamente associada à CVC - como referência. Adicionalmente, foram realizadas análises comparativas de regiões regulatórias correspondentes entre cepas de $X$. fastidiosa, provenientes de hospedeiros e regiões geográficas distintas, com o intuito de acessar o grau de variabilidade subjacente à regulação transcricional desta espécie e elencar conjuntos de genes cujas sequências promotoras sugerem mecanismos de regulação distintos entre cepas.

\section{Metodologias}

\subsection{Definição de clusters gênicos - genes ortólogos}

A identificação de grupos de genes ortólogos foi feita utilizando-se a ferramenta INPARANOID (Remm et al., 2001), que utiliza a estratégia de melhor hit (BLAST) bidirecional entre dois genomas, isto é, quando o melhor resultado de uma busca BLAST é recíproco entre duas proteínas de genomas distintos, para identificar pares de genes que compartilharam um ancestral comum e divergiram através de um mecanismo de especiação. A matriz BLOSUM 62 foi utilizada para avaliar os alinhamentos e para o restante dos parâmetros foram utilizadas as configurações padrões.

\subsection{Inferência de TFBSs a partir de informações de regulação transcricional da bactéria modelo Escherichia coli - scanning}

Com o intuito de extrapolar as informações de regulação de Escherichia coli para $X$. fastidiosa cepa 9a5c a metodologia descrita a seguir foi aplicada, com base nos dados experimentais contidos no banco de dados RegulonDB (Gama-Castro et al., 2011), $\begin{array}{lllll}\text { atualizado em } 29 \text { de } & 2012\end{array}$ (http://regulondb.ccg.unam.mx/download/Data_Sets.jsp): 
Primeiramente, ortólogos entre $X$. fastidiosa $9 a 5$ c e $E$. coli K-12 foram identificados utilizando-se a ferramenta INPARANOID. Em seguida, todas as interações TF/TFBS presentes no banco de dados foram capturadas e matrizes de TFBSs foram geradas para os TFs que apresentassem pelo menos quatro sítios de ligação (TFBSs) já caracterizados, os demais TFs foram desconsiderados nas etapas seguintes. Para cada par TF/gene regulado de $E$. coli conservado em $X$. fastidiosa inspecionou-se a sequência promotora do gene regulado correspondente em $X$. fastidiosa a procura de TFBSs conservados, utilizando-se a matriz representante do par TF/TFBS de E. coli. Esta tarefa foi realizada com ferramenta MAST (Bailey e Gribskov, 1998) que foi configurada para avaliar ambas as fitas dos promotores (+ e -). Definiu-se como região promotora a sequência de 350 pares de bases a montante do sítio de início de tradução do primeiro gene, localizado na extremidade 5', da unidade transcricional (para detalhes sobre a definição de unidade transcricional ver tópicos 3.3). Caso a distância entre duas unidades transcicionais presentes na mesma fita seja menor que 350 pares de bases, a região promotora da unidade transcricional a jusante é definida como sendo a distância intergênica entre elas.

Ao fim do processo todos os hits de uma mesma matriz foram alinhados e utilizados para gerar novas matrizes, as matrizes Xylella-específicas, as quais foram utilizadas para varrer as sequências promotoras de todas as unidades transcricionais de $X$. fastidiosa 9a5c, dando origem aos respectivos regulons. A figura 1 representa o fluxograma desta análise. 


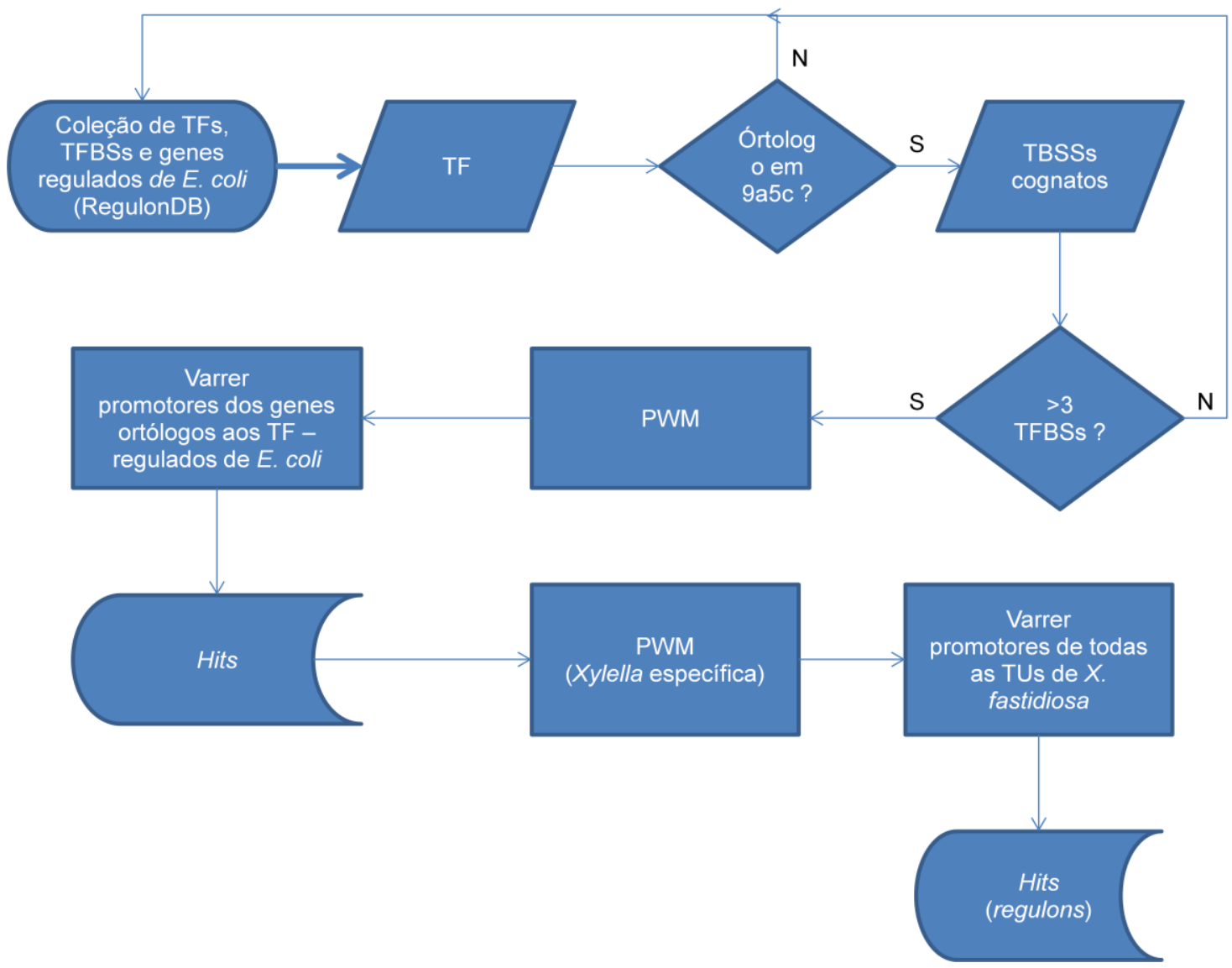

Figura 1: Fluxograma para inferência de regulons a partir de dados de $E$. coli recuperados do repositório RegulonDB. A seta larga representa o ponto de início do processo, $\mathrm{S}$ e $\mathrm{N}$ referem-se a sim e não, respectivamente, nas tomadas de decisão. Para cada TF de $E$. coli que apresente ortólogo em de $X$. fastidiosa 9a5c, gerou-se uma PWM (com, no mínimo, 4 TFBSs) que foi utilizada para varrer as sequências dos promotores dos genes ortólogos aos TF- regulados de $E$. coli. Com os hits obtidos gerouse uma nova matriz que foi utilizada para varrer as sequências promotoras de todas as unidades transcricionais (TUs) de $X$. fastidiosa 9a5c, dando origem aos regulons.

\subsection{Inferência ab initio de motivos regulatórios - phylogenetic footprinting}

Para predição $a b$ initio de motivos cis-regulatórios no genoma de $X$. fastidiosa cepa $9 a 5 c$ sete espécies comparativas foram selecionadas (ver 4.2.2), das quais os respectivos ortólogos de cada gene de $X$. fastidiosa foram identificados. A escolha destas espécies foi realizada considerando-se as seguintes características e critérios, apontados como relevantes em outros estudos (McCue et al., 2002; Espinosa et al., 2005; Zhang et al., 2009):

1. Tamanho genômico em pares de bases e número de ORFs (open reading frames).

2. Habitat de onde foi isolada.

3. Seja uma proteobacteria, preferencialmente do tipo gama.

4. Seja possível identificar ortólogos para, pelo menos, 30\% dos genes de $X$. fastidiosa. 
5. Seja possível identificar ortólogos para, pelo menos, $25 \%$ dos fatores transcricionais de $X$. fastidiosa. Os genes considerados codificantes de fatores transcricionais são os mesmos que foram preditos no trabalho de (Wilson et al., 2008), os quais estão publicamente disponíveis no banco de dados do DBD (http://dbd.mrcImb.cam.ac.uk/DBD/index.cgi?Browse).

Em seguida, os genomas das oito bactérias ( $X$. fastidiosa $9 a 5 c$ e as outras sete $\begin{array}{lllll}\text { espécies) foram } & \text { submetidos } & \text { ao } & \text { servidor } & \text { DOOR }\end{array}$ (http://csbl1.bmb.uga.edu/OperonDB/DOOR.php) para que fossem feitas as predições de operons nestas espécies. $\mathrm{O}$ algoritmo utilizado para a predição de estrutura de operons neste servidor (Dam et al., 2007) tem sido considerado o melhor e mais consistente (Brouwer et al., 2008). As estruturas de operons e os ortólogos foram então combinados para possibilitar a identificação de unidades transcricionais (TUs, transcription units) ortólogas entre $X$. fastidiosa e as outras espécies. O conceito de TUs ortólogas já foi utilizado em outro trabalho (Wels et al., 2006) no qual se considerou que duas TUs são ortólogas se aquela de maior tamanho (em termos de número de genes) contém genes ortólogos a, pelo menos, $50 \%$ dos genes presentes na TU de menor tamanho. Após um estudo preliminar do conceito (ver tópico 3.3.1 e 4.2.1) um novo critério foi adotado, com o qual duas TUs são consideradas ortólogas se o valor de similaridade entre elas, computado conforme a equação 2 (tópico 3.3.1), for maior ou igual a 0.5 .

Cada TU predita em $X$. fastidiosa deu origem a um grupo ortólogo, que é composto pela TU de $X$. fastidiosa e todas suas ortólogas identificadas nas outras sete espécies. Os grupos gerados só são considerados para as análises subsequentes se contiverem pelo menos uma TU de três espécies distintas, ou seja, $X$. fastidiosa e outras duas quaisquer.

O próximo passo consistiu na comparação das regiões promotoras de todas as TUs presentes em um mesmo grupo ortólogo. Para isso definiu-se como região promotora a sequência de 350 pares de bases a montante do sítio de início de tradução do primeiro gene (localizado na extremidade $5^{\prime}$ ) da unidade transcricional. Caso a distância entre duas unidades transcicionais presentes na mesma fita seja menor que 350 pares de bases a região promotora da unidade transcricional a jusante é definida como sendo a distância intergênica entre elas.

Os promotores foram analisados com ferramentas especializadas para a identificação de subsequências super-representadas em um conjunto de sequências de DNA, estas ferramentas e suas configurações são apresentadas a seguir: MEME (Bailey, 1994), utilizada em dois contextos independentes, um dedicado a identificar motivos palindrômicos e outro dedicado a identificar motivos não palindrômicos, nos quais permitiu-se que o tamanho dos motivos variasse de 8 a 30 pares de bases; BioProspector (Liu et al., 2001), configurada para identificar motivos de 20 pares de bases; Phylogibbs (Siddharthan et al., 2005), configurada para identificar motivos de 20 pares de bases; MotifSampler (Thijs et al., 2002), configurada para identificar motivos de 16 pares de bases. Estudos sugerem que o uso de mais de uma ferramenta melhora significativamente a identificação de motivos regulatórios, ou seja, as diversas ferramentas disponíveis são, em geral, complementares e combinar seus resultados retendo somente a intersecção das predições é aconselhável já que a acurácia 
destas pode variar bastante dependendo do conjunto de dados em que são aplicadas e as configurações utilizadas (Tompa et al., 2005; Li e Tompa, 2006; Rodionov, 2007).

Todas as ferramentas utilizadas foram configuradas para identificar 3 motivos, gerando um total de 15 para cada grupo de promotores. Tendo em vista que alguns desses motivos possam não ser funcionais, selecionou-se apenas um para prosseguir as análises. 0 motivo selecionado foi aquele predito um maior número de vezes, ou seja, aquele identificado pelo maior número de ferramentas dentre as utilizadas e, portanto, com maiores chances de ser funcional. Em casos de empate, o motivo com maior IC (information content) foi selecionado para as próximas etapas, sendo que quanto maior o IC menor é a variabilidade do motivo (GuhaThakurta, 2006). Para caracterizar o número de vezes que um dado motivo foi predito em um conjunto de promotores, utilizou-se a ferramenta motifcomparison (Claeys et al., 2012) para alinhar as matrizes representantes dos motivos preditos, exigindo-se sobreposição mínima de 10 posições entre as matrizes alinhadas.

As matrizes correspondentes aos motivos selecionados no passo anterior foram utilizadas para identificar instâncias adicionais ao longo dos promotores das TUs de $X$. fastidiosa, por meio da ferramenta MAST configurada para avaliar ambas as fitas (+ e -). Da mesma forma, instâncias adicionais foram identificadas nas sequências de DNA das regiões codificantes, excluindo-se os genes hipotéticos, como uma forma de acessar a taxa de falsos positivos. A ferramenta MAST, utilizada para esta etapa de scanning, associa a cada hit (instância) um p-valor. As proporções de hits obtidos nas regiões promotoras e codificantes foram calculadas para diferentes critérios de corte ( $p$-valor) e assim definiu-se um $p$-valor que beneficiaria a seleção de hits (instâncias) nas regiões promotoras em detrimento àqueles obtidos nas regiões codificantes, já que estes últimos apresentam uma maior chance de serem não funcionais.

Os hits em regiões promotoras que satisfizeram o valor de corte estabelecido ( $\mathrm{p}<=$ $1,00 \mathrm{E}^{-08}$, ver tópico 4.2.2 para detalhes a respeito da escolha deste valor) foram capturados e utilizados para se construir novas matrizes, uma para cada motivo anteriormente predito, dando origem às matrizes Xylella-específicas. As matrizes Xylella-específicas geradas a partir de 3 hits ou mais foram utilizadas para identificar novas instâncias (hits) ao longo dos promotores e, dessa forma, definiram-se os respectivos regulons, ou seja, conjunto de TUs que compartilham instâncias de um mesmo motivo em seus promotores. A figura 2 mostra, de forma simplificada, as sequências de operações para realização da abordagem descrita. 
1. Seleção de espécies comparativas

\section{Critérios para seleção de espécies comparativas}

1. Tamanho genômico e número de ORFs semelhantes

2. Isolado de ambiente semelhante ao de $X$. fastidiosa

3. $30 \%$ ou mais de genes ortólogos em $X$. fastidiosa

4. $25 \%$ ou mais de TFs ortólogos em $X$. fastidiosa

5. Preferencialmente uma gammaproteobacteria
2. Seleção de

TUs ortólogas

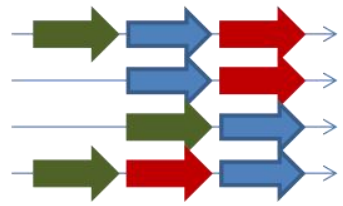

3. Recuperação dos promotores das TUs ortólogas

ATCGTTGACTAGCTGTTGA ATGTCTGACTACGTCAGTT GCATAGTACTACGATGA

\section{Predição $a b$ initio} de TFBSS

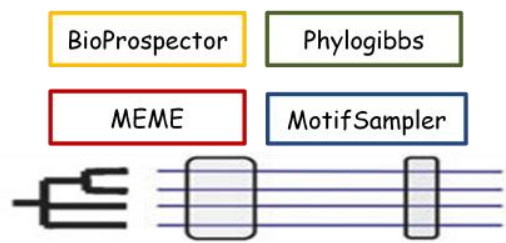

7. Seleção de hits significativos

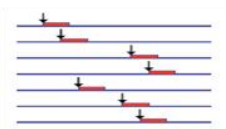

5. Seleção de motivos

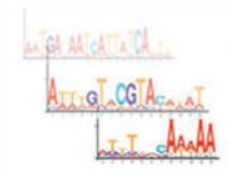

8. Construção de PWMs específicas

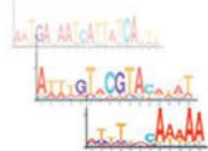

6. Scanning

(varredura)

\section{MAST}

9. Scanning (varredura)

*definição dos regulons

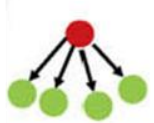

Figura 2: Representação da metodologia para predição ab initio de motivos regulatórios. Inicialmente selecionou-se um conjunto de sete espécies comparativas seguindo os critérios apontados (1). Em seguida os grupos TUs ortólogas foram resgatados, cada qual contendo uma TU de $X$. fastidiosa e suas demais ortólogas (2). Os promotores de cada grupo de TUs ortólogas foram resgatados (3) e submetidos a ferramentas especializadas para predição de elementos conservados (4). Dentro de cada grupo, o motivo predito com maior frequência foi selecionado (5) e utilizado para varrer as sequências promotoras de todas as TUs de $X$. fastidiosa (6). Os hits significativos foram selecionados (7) e usados para gerar um modelo (matriz) Xylella-específico (8), o qual foi utilizado para varrer as regiões promotoras de todas as TUs de $X$.fastidiosa, dando origem ao seu respectivo regulon (9).

\subsubsection{Critério para identificação de unidades transcricionais ortólogas}

Um grande desafio de se aplicar a abordagem de phylogenetic footprinting para identificação de elementos cis-regulatórios em procariotos é a maneira de como lidar com os operons.

Um operon consiste em genes contíguos que são transcritos como uma única fita de mRNA (Lathe et al., 2000), ou seja, genes presentes em um mesmo operon estão sujeitos ao mesmo mecanismo de controle transcricional e, portanto, não podem ser analisados separadamente. Por isso faz-se necessário definir um critério capaz de identificar unidades transcricionais ortólogas, para aquelas unidades que apresentam mais de um gene em sua composição (operon). O termo "unidades transcricionais ortólogas" (TUs ortólogas) refere-se a unidades transcricionais cujas regiões promotoras contêm sítios reconhecidos por fatores de transcrição ortólogos. 
No estudo de (Wels et al., 2006) considerou-se que duas TUs são ortólogas quando aquela com maior número de genes contém ortólogos para, pelo menos, 50\% dos genes da outra TU. Esta definição não leva em consideração a diferença do número de genes presentes nas TUs comparadas, ou seja, o número de deleções e/ou inserções sofridas pelas mesmas desde o momento em que divergiram, mas somente a proporção de genes compartilhados (ortólogos) e, portanto, pode não ser adequada para comparar TUs muito discrepantes. Por isso uma maneira de calcular o grau de similaridade entre duas TUs foi definida, que leva em consideração o número de genes contido em cada uma, designada aqui como classificador proposto. A equação utilizada para calcular o grau de similaridade (GS) é a que segue abaixo (equação 2), na qual menTU é o número de genes da menor unidade transcricional, maiTU é o número de genes da maior unidade transcricional e Ort é o número de ortólogos compartilhados pelas unidades transcricionais :

$$
G S=\sqrt{(\text { menTU } \div \text { maiTU }) \times(O r t \div \text { maiTU })}
$$

Equação 2: Equação proposta para calcular o grau de similaridade entre duas unidades transcricionais.

Com o intuito de verificar a existência de um valor de corte de GS que fosse adequado para a identificação de TUs ortólogas, realizou-se a análise descrita a seguir:

Inicialmente informações de regulação transcricional foram recuperadas a partir de bancos de dados publicamente disponíveis [PRODORIC (Munch et al., 2003), RegTransbase (Kazakov et al., 2007), DBTBS (Sierro et al., 2008), RegulonDB (Gama-Castro et al., 2011)], sobre as regulações exercidas por fatores transcricionais ortólogos nos seguintes pares de espécies consideradas modelos amplamente estudados: E. coli $\mathrm{K} 12$ e Pseudomonas aeruginosa PAO1 e E. coli K12 e Bacillus subtilis 168. Em cada par de espécies foi analisado o grau de similaridade (GS) existente, quando existente, entre TUs reguladas por fatores transcricionais ortólogos, impondo-se a restrição de que pelo menos uma das duas TUs comparadas deva conter mais de um gene em sua composição. Presume-se que os valores de GS obtidos neste conjunto correspondam à distribuição do grau de similaridade existente entre TUs reguladas por TFs ortólogos, dando origem à distribuição de GS do conjunto verdadeiro (TUs verdadeiramente ortólogas). O restante dos pares de TUs que compartilham ao menos um gene (ortólogos), mas que a principio não são reguladas por TFs ortólogos compuseram o conjunto dos falsos, ou seja, TUs que apresentam similaridade entre si mas que não compartilham elementos cis-regulatórios em seus promotores. Esta premissa é uma extrapolação da realidade, pois estima-se que uma quantidade considerável de interações regulatórias são ainda desconhecidas até mesmo em organismos modelos (van Hijum et al., 2009) e somente foi utilizada devido à ausência de outro conjunto mais adequado para o presente estudo.

Os valores de similaridade foram utilizados para acessar as taxas de verdadeiros positivo e falsos positivos obtidos para diferentes valores GS de corte pré-estabelecidos, tendo em vista os conjuntos verdadeiro e falso definidos. Os valores de corte utilizados variaram de 0,1 a 1,0, em janelas de 0,1 . 
A título de comparação, a mesma metodologia foi repetida utilizando-se a equação 3 para calcular o valor de similaridade entre duas TUs. Esta maneira de calcular a similaridade entre TUs corresponde ao utilizado em (Wels et al., 2006), designado aqui como classificador referência.

$$
G S=O r t \div m e n T U
$$

Equação 3: Equação utilizada para calcular o grau de similaridade entre duas unidades transcricionais de acordo com (Wels et al., 2006).

\subsubsection{Acessando a consistência dos regulons}

A consistência dos regulons preditos foi acessada de duas maneiras: calculando-se a média das correlações dos valores de expressão dos genes contidos em um mesmo regulon, tomando como base valores de expressão gênica global de 32 experimentos de microarranjos de DNA (da Silva, 2010), e analisando a existência ou não de categorias funcionais COG super-representadas em cada regulon predito.

\subsubsection{Super-representação de classes COG dos regulons - teste de Fisher}

Para a análise de super-representação de categorias funcionais COG, utilizou-se o teste exato de Fisher a um nível de significância $0,05(p<0,05)$. Cada gene de $X$. fastidiosa $9 a 5 c$ é caracterizado como pertencente à nenhuma, uma ou mais de uma categoria funcional COG. O teste exato de Fisher calcula se os regulons apresentam um viés de enriquecimento para uma ou mais categoria funcional. A expectativa é que verdadeiros regulons estejam enriquecidos com genes pertencentes a uma mesma categoria.

\subsubsection{Correlação de expressão dos genes dos respectivos regulons - Média da correlação de Pearson}

Para definir a correlação média de expressão de um regulon, calculou-se primeiramente a correlação de Pearson para todas as combinações par a par dos genes nele contido e, em seguida, a média das correlações foi calculada e atribuída ao respectivo regulon. 


\subsubsection{Identificação de TFs cognatos putativos}

Para associar os novos motivos com potenciais reguladores utilizamos duas abordagens, descritas a seguir.

\subsubsection{Similaridade com motivos de Escherichia coli}

O teste de similaridade consistiu em comparar os motivos preditos com motivos já caracterizados em E. coli, cujas matrizes correspondentes estão disponíveis no banco de dados RegulonDB. Esta tarefa foi realizada com a ferramenta TOMTOM (Bailey et al., 2009), configurada para aceitar alinhamentos com sobreposição mínima de seis posições entre as matrizes e reter aqueles com e-valor menor que 0,5. Hits com motivos cujos TFs cognatos não estão presentes no genoma de $X$. fastidiosa $9 a 5 c$ foram desconsiderados.

\subsubsection{Inferência a partir da distância mínima entre pares de TFs e motivos regulatórios}

Esta abordagem está pautada no princípio de que existe uma restrição na distância entre um gene codificante de TF e seu sítio de ligação mais próximo (Tan et al., 2005; Fadda et al., 2009), isto é, TFs e TFBSs tendem a estar próximos no genoma.

Para cada motivo predito, calculamos as distâncias em pares de bases entre as instâncias correspondentes (hits) e cada um dos genes codificantes de TF do genoma de $X$. fatidiosa 9a5c, tendo como referência as posições genômicas dos centros das instâncias e dos genes. O repertório de TFs foi definido como sendo todos os genes presentes no repositório DBD somados àqueles previamente anotados como fatores de transcrição. Para cada par instância-TF, dois valores de distância são possíveis se levarmos em consideração a circularidade do cromossomo e, portanto, o menor dos valores foi considerado. A distância mínima entre um TF e um motivo qualquer equivale a menor distância instância-TF possível, considerando todas as instâncias correspondentes ao motivo em questão. TFs e motivos que apresentam a distância mínima menor que o valor de corte estabelecido (ver a seguir) são considerados potenciais pares cognatos.

Para definir um critério de corte calculamos as distâncias mínimas de cada regulon predito a partir das informações experimentais de $E$. coli, dando origem a uma distribuição de distâncias mínimas entre verdadeiros pares de TFs e motivos (cognatos). Da mesma forma, as distâncias mínimas entre TFs e motivos não cognatos foram calculadas, dando origem a uma distribuição de distâncias mínimas entre falsos pares de TFs e motivos (não cognatos). A partir dos resultados obtidos para distâncias mínimas entre os pares verdadeiros e falsos, definimos um valor de corte de distância mínima (ver discussão para 
detalhes) que rendesse a melhor combinação de precisão e recuperação, quando aplicada nos regulons inferidos a partir dos dados experimentais de E. coli. Recuperação e precisão foram definidas como se segue:

Recuperação $=$ VP / (VP+FN)

Precisão $=$ VP $/(\mathrm{VP}+\mathrm{FP})$

$\mathrm{VP}=$ taxa de verdadeiros positivos, $\mathrm{FN}=$ taxa de falsos negativos, $F P=$ taxa de falsos positivos.

\subsection{Análises comparativas entre cepas de Xylella fastidiosa}

\subsubsection{Promotores críticos}

Com o intuito de detectar diferenças regulatórias entre cepas de Xylella fastidiosa as regiões promotoras das TUs conservadas foram comparadas entre seguintes pares: 9a5c $x$ Temecula1 e 9a5c x J1a12. Duas TUs são consideradas conservadas se suas sintenias são idênticas ou se os contextos genômicos de seus promotores estão conservados, ou seja, se os genes das extremidades $5^{\prime}$ das TUs e os genes vizinhos imediatamente a montante às TUs comparadas são correspondentes (ortólogos), como exemplificado na figura 3. Desta forma, minimizamos as chances de comparar regiões não homólogas.

Para levar em consideração as estruturas de operons, típicas de procariotos, definiuse que dois genes vizinhos com distância intergênica menor que 50 pares de bases fazem parte da mesma unidade transcricional e, portanto, genes presentes a uma mesma unidade transcricional estão associados a um mesmo promotor. Por definição considerou-se como promotor a região de 350 pares de bases imediatamente a montante em relação ao sítio de início de tradução do primeiro gene (extremidade $5^{\prime}$ ) da unidade transcricional. Caso a distância entre duas unidades transcicionais presentes na mesma fita seja menor que 350 pares de bases a região promotora da unidade transcricional a jusante é definida como sendo a distância intergênica entre elas. 
A
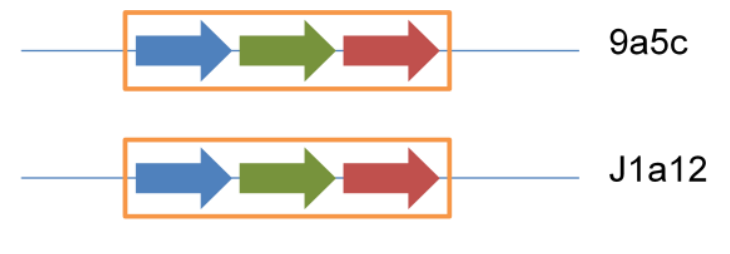

B
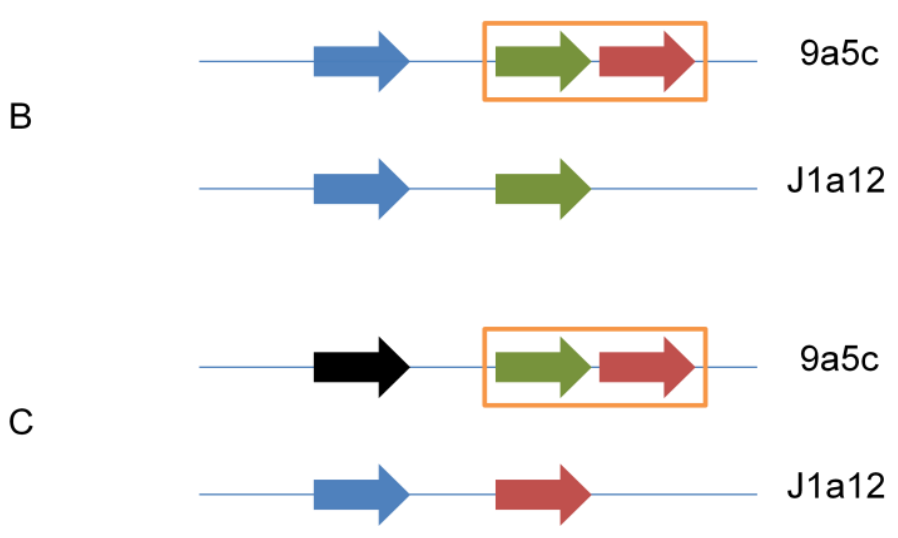

Figura 3: Representação hipotética de unidades transcricionais com sintenias idênticas $(A)$ entre duas cepas quaisquer (por exemplo, 9a5c e J1a12), de unidades transcricionais com sintenias corrompidas, mas com contextos genômicos dos promotores conservados (B) e de unidades transcricionais com sintenias e contextos genômicos dos promotores corrompidos (C). Genes ortólogos estão representados como setas de mesma cor. Genes contidos em retângulos laranjas representam as estruturas de operons.

Os alinhamentos das sequências promotoras foram realizados com o algoritmo de alinhamento local (Smith e Waterman, 1981) implementado no pacote EMBOSS (Rice et al., 2000), para os quais foi computado o score normalizado pelo comprimento do alinhamento. Todos os pares de promotores que apresentaram score normalizado de um desvio-padrão ou mais abaixo da média, referente ao par de cepas em questão, foram considerados pares de promotores críticos, ou seja, promotores com diferenças significativas em suas sequências.

Uma lista de promotores críticos foi compilada para cada par de cepas e os promotores desta lista foram inspecionados com as matrizes Xylella-específicas, geradas a partir das informações regulatórias de E. coli, a procura de instâncias (hits) dos motivos regulatórios. Nesta etapa a ferramenta MAST foi utilizada e os resultados obtidos (hits) foram manualmente curados com o intuito de identificarmos diferenças nos pares de promotores críticos potencialmente relacionadas a elementos cis-regulatórios.

\subsubsection{Distribuição de motivos regulatórios em diferentes genomas de Xylella fastidiosa - matrizes cepa-específicas}

Para avaliar a distribuição dos motivos preditos pela abordagem ab initio em diferentes genomas de $X$. fastidiosa, as matrizes correspondentes aos motivos selecionados de cada grupo de TUs ortólogas (etapa 5 da figura 2) foram utilizadas para inspecionar independentemente as sequências promotoras das TUs de Xanthomonas albilineans GPE 
PC73 e cada uma das 12 cepas de Xylella fastidiosa disponíveis (ver tópico 3.5.1), utilizandose a ferramenta MAST. Motivos com mais de 3 hits em um mesmo genoma foram modelados em novas matrizes, a partir dos hits obtidos, e estas utilizadas para reinspecionar as sequências promotoras do genoma em questão. Os hits resultantes desta última etapa deram origem às matrizes cepa-específicas.

\subsubsection{Análises filogenéticas baseadas em motivos regulatórios}

As matrizes cepa-específicas foram utilizadas para inferir relações filogenéticas entre 12 cepas de $X$. fastidiosa, utilizando-se o genoma de Xanthomonas albilineans GPE PC73 como grupo externo. As inferências foram realizadas em três contextos distintos, variando-se a métrica para o cálculo da matriz de distância. Em todos eles utilizou-se o método de neighbor-joining (Saitou e Nei, 1987), implementado no pacote PHYLIP, com 1000 pseudoréplicas de bootstrap.

No primeiro contexto a matriz de distância foi calculada com base nos padrões de presença e ausência dos motivos regulatórios, sendo que cada motivo em comum contribuiu aditivamente com uma unidade no valor de similaridade entre pares de genomas. Para fins de normalização o valor de similaridade entre dois genomas é tido como a proporção de motivos compartilhados em relação ao total (não redundante) presente no par comparado. No segundo contexto, a matriz de distância foi calculada a partir de valores de similaridade entre motivos correspondentes, levando em consideração apenas os motivos comuns aos 13 genomas. O valor de similaridade entre dois motivos A e B correspondentes foi definido como sendo o score do alinhamento resultante entre eles, obtido com a ferramenta motifcomparison, normalizado pelo maior score obtido a partir dos auto-alinhamentos: A x A e B x B. O valor de similaridade entre dois genomas foi computado a partir da soma dos valores de similaridade entre motivos correspondentes, normalizado pelo número de motivos comuns aos 13 genomas. No terceiro contexto, tanto o padrão de presença e ausência como os valores de similaridade entre motivos correspondentes foram considerados e o valor de similaridade entre dois genomas foi normalizado pelo número total de motivos presentes nos pares comparados.

\subsection{Sequências genômicas utilizadas}

Todas as análises foram realizadas com as sequências cromossômicas diretamente recuperadas do repositório do GenBank (Benson et al., 2012), exceto nas análises comparativas entre cepas de $X$. fastidiosa para as quais as sequências, publicamente disponíveis (GenBank) e recém sequenciadas por integrantes do laboratório da Profa. Dra. Aline Maria da Silva (não publicadas), foram previamente submetidas à plataforma IMG/ER 
(https://img.jgi.doe.gov/er/) (Markowitz et al., 2012) do DOE JGI para padronização das anotações.

\subsubsection{Análise comparativa entre cepas de Xylella fastidiosa}

GenBank: Xylella fastidiosa 9a5c (hemisfério sul), Xylella fastidiosa Temecula1 (hemisfério norte), Xylella fastidiosa Dixon (hemisfério norte), Xylella fastidiosa G514 (hemisfério norte), Xylella fastidiosa M12 (hemisfério norte), Xylella fastidiosa M23 (hemisfério norte).

Não publicado: Xylella fastidiosa U24d (hemisfério sul), Xylella fastidiosa J1a12 (hemisfério sul), Xylella fastidiosa Fb7 (hemisfério sul), Xylella fastidiosa Pr8x (hemisfério sul), Xylella fastidiosa 3124 (hemisfério sul), Xylella fastidiosa Hib4 (hemisfério sul).

\subsubsection{Demais análises}

GenBank: Xylella fastidiosa 9a5c, Dickeya dadantii Ech586, Erwinia amylovora CFBP1430, Pectobacterium carotovorum subsp. carotovorum PC1, Pseudomonas syringae pv. tomato str. DC3000, Ralstonia solanacearum CFBP2957, Stenotrophomonas maltophilia R551-3, Xanthomonas axonopodis pv. citri str. 306, Xanthomonas albilineans GPE PC73, Escherichia coli str. K-12 substr. MG1655, Pseudomonas aeruginosa PAO1 e Bacillus subtilis subsp. subtilis str. 168.

\subsection{Automação}

As análises do presente trabalho foram realizadas com o auxílio de scripts, escritos nas linguagens Perl e R. 


\section{Resultados e Discussão}

\subsection{Inferência de TFBSs a partir de informações de regulação transcricional da bactéria modelo Escherichia coli - scanning}

Aproveitar a abundância de informações sobre regulação transcricional de uma espécie para inferir novas regulações em espécies menos estudadas tem sido uma abordagem comum para elucidação de regulons em bactérias (Tan et al., 2001; Liu et al., 2008; Ravcheev et al., 2011; Rodionov et al., 2011).

RegulonDB (Gama-Castro et al., 2011), um banco de dados publicamente disponível, contém informações experimentais a respeito de motivos regulatórios da bactéria modelo $E$. coli e, por se tratar de uma espécie filogeneticamente relacionada a $X$. fastidiosa (ambas proteobacterias do tipo gama), é plausível acreditar que algumas das interações TF/TFBS se conservem nas duas espécies. (Perez et al., 2007) utilizou-se desta premissa e extrapolou o conhecimento de regulons previamente caracterizados em E. coli para diversas proteobacterias do tipo gama, inclusive $X$. fastidiosa (tabela 1 ). Apesar disso, acreditamos que novas regulações elucidadas em $E$. coli desde a realização do trabalho de Perez e colegas pudessem permitir que interações outrora perdidas pelo trabalho destes autores fossem agora detectadas em $X$. fastidiosa.

Do banco de dados RegulonDB foi possível recuperar informações de regulação para 97 fatores transcricionais de $E$. coli, dos quais 21 possuem pelo menos uma cópia ortóloga no genoma de $X$. fastidiosa 9a5c. Para 20 TFs foi possível identificar pelo menos uma evidência de regulação conservada em $9 a 5 c$ e para apenas 10 foi possível identificar quatro sítios de ligação ou mais, critério mínimo para construção das matrizes Xylella específicas que foram utilizadas posteriormente para predição dos respectivos regulons mostrados na tabela 2 (genes anotados como hipotéticos não estão inclusos).

Como esperado, novas interações entre TFs e genes regulados de fato foram identificadas através da metodologia aplicada. Quatro TFBSs identificadas por outros trabalhos (tabela 1) foram corroborados com nossa metodologia: um sítio de CRP identificado no gene 15838917 (XF2326) (Perez et al., 2007), codificador de uma fosfoserina aminotransferase; um sítio reconhecido por Fur no gene 15837201 (XF0599), codificador de um receptor de sideróforo, experimentalmente validado (Zaini et al., 2008); um sítio de PhoB no gene 15838732 (XF2141), codificador de um transportador de fosfato (Perez et al., 2007); e um sítio de ligação de NrdR no gene 15837798 (XF1196) (Novichkov et al., 2010a), codificador de uma ribonucleosídeo difosfato redutase. Este último não consta na tabela 2, pois não foi possível identificar o número mínimo de hits para expansão do regulon de NrdR.

$O$ conhecimento de 10 regulons bem caracterizados em $E$. coli foi extrapolado para $X$. fastidiosa. Todos eles compostos por genes cujas funções estão de acordo como que se conhece sobre o regulon em outras espécies melhor estudadas, tal como E. coli. As características funcionais de cada um dos 10 fatores transcricionais são brevemente descritas na tabela 3. 
Tabela 2: Regulons preditos a partir de dados experimentais de E. coli.

\begin{tabular}{|c|c|c|}
\hline Nome do TF de $E$. coli & $\begin{array}{l}\text { Identificador do gene } \\
\text { ortólogo em } 9 \mathrm{a} 5 \mathrm{c}\end{array}$ & Genes com sítios de ligação em 9a5c (produto [identificador do gene]) \\
\hline LexA & 15836727 & 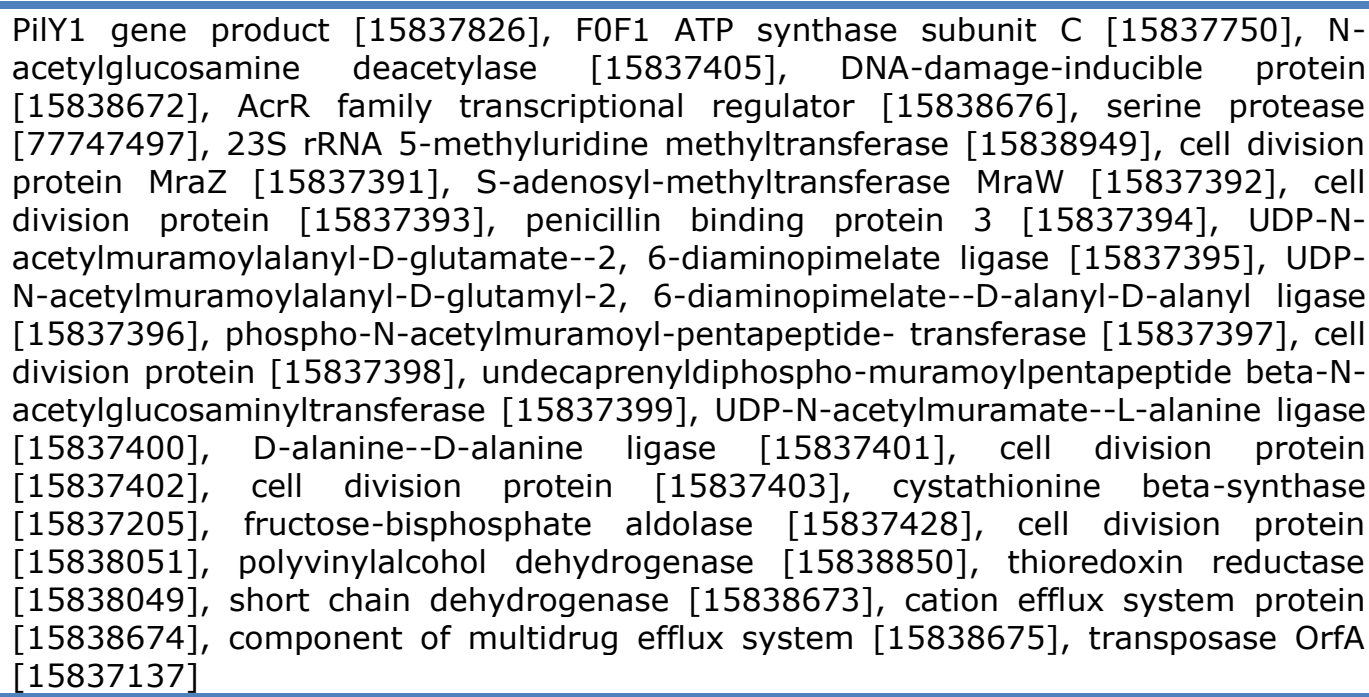 \\
\hline Fis & 15838592 & $\begin{array}{l}\text { aspartyl-tRNA synthetase }[15838454] \text {, elongation factor Tu }[15839217] \text {, elongation } \\
\text { factor G [15839218], ribonucleotide-diphosphate reductase subunit alpha } \\
{[15837798], \text { ribonucleotide-diphosphate reductase subunit beta [15837799], }} \\
\text { flavodoxin }[15837800] \text {, thioredoxin }[15837801]\end{array}$ \\
\hline DnaA & 15836606 & $\begin{array}{l}\text { DNA-binding protein [15837048], 30S ribosomal protein S15 [15836843], GTP- } \\
\text { dependent nucleic acid-binding protein EngD [15839230], peptidyl-tRNA hydrolase } \\
{[15839231], 50 S \text { ribosomal protein L25/general stress protein Ctc [15839232], }} \\
\text { pathogenicity-related protein [15837622] }\end{array}$ \\
\hline PurR & 15838064 & 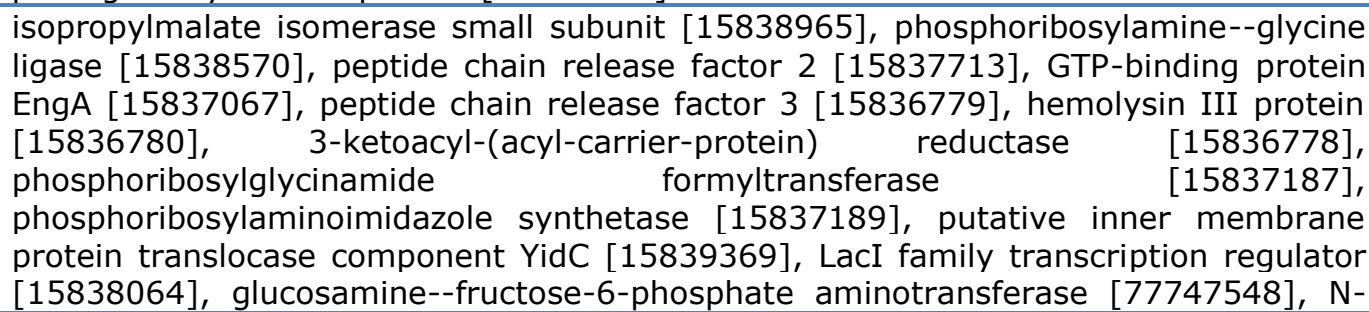 \\
\hline
\end{tabular}




\begin{tabular}{|c|c|c|}
\hline & & acetylglucosamine-6-phosphate deacetylase [15838066] \\
\hline NsrR & 15838078 & $\begin{array}{l}\text { surface-exposed outer membrane protein [15838117], ribosome-binding factor A } \\
{[15836841] \text {, fimbrillin [15837140], fimbrillin [15837141], orotidine 5'-phosphate }} \\
\text { decarboxylase [15836639], } 50 \text { S ribosomal protein L32 [15838414] }\end{array}$ \\
\hline PhoP & 15836991 & $\begin{array}{l}\text { PilY1 gene product }[15837826] \text {, protein-L-isoaspartate O-methyltransferase } \\
{[15839174] \text {, outer membrane export factor }[15839175] \text {, outer membrane protein }} \\
{[15837655] \text {, heat shock protein }[15836890], 50 S \text { ribosomal protein L1 [15839225], }} \\
50 S \text { ribosomal protein L11 }[161378155] \text {, two-component system, regulatory protein } \\
{[15836991] \text {, two-component system, sensor protein [15836992], UDP-N- }} \\
\text { acetylglucosamine pyrophosphorylase }[15837742]\end{array}$ \\
\hline CRP & 15838141 & 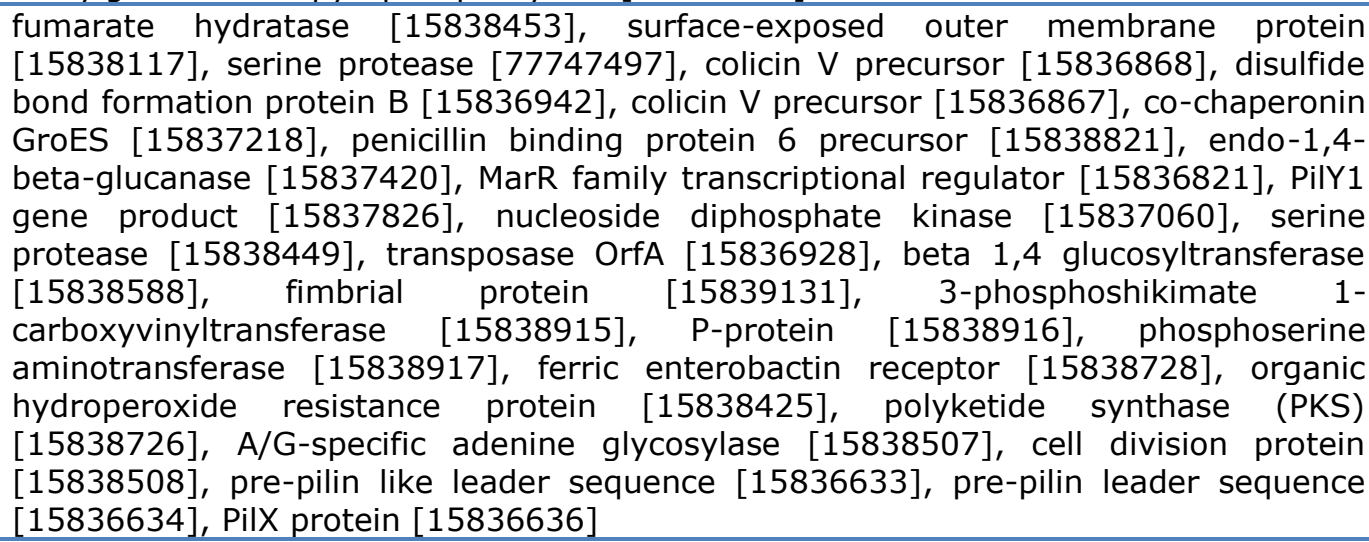 \\
\hline PhoB & 15839182 & $\begin{array}{l}\text { 6-phosphogluconolactonase }[15837665], \text { glucokinase }[15837666] \text {, glucose-6- } \\
\text { phosphate 1-dehydrogenase }[15837667] \text {, alkaline phosphatase [77747510], ABC } \\
\text { transporter sugar permease [15839037], ABC transporter sugar permease } \\
{[15839038], A B C \text { transporter sugar-binding protein [15839039], sugar ABC }} \\
\text { transporter ATP-binding protein [15837669], glutamate symport protein [15837258], } \\
\text { twitching motility protein [15838233], amino acid transporter [77747501, } \\
\text { protoheme IX farnesyltransferase [15837961], ABC transporter phosphate binding } \\
\text { protein [15838732], ABC transporter phosphate permease [15838733], ABC } \\
\text { transporter phosphate permease [15838734], phosphate transporter ATP-binding } \\
\text { protein [77747585], phosphate regulon transcriptional regulator [15838736] }\end{array}$ \\
\hline Fur & 15838935 & $\begin{array}{l}\text { DNA-binding protein }[15837048] \text {, fumarate hydratase }[15838453] \text {, surface-exposed } \\
\text { outer membrane protein }[15838117] \text {, DNA-damage-inducible protein }[15838672] \text {, } \\
\text { serine protease }[77747497], \text { membrane protein }[15837366] \text {, ArsR family } \\
\text { transcriptional regulator }[15837369], \text { GDP-mannose } 4,6 \text { dehydratase }[15837211] \text {, }\end{array}$ \\
\hline
\end{tabular}




\begin{tabular}{|c|c|c|}
\hline & & $\begin{array}{l}\text { UDP-glucose 4-epimerase [15837212], dTDP-glucose 4-6-dehydratase [15837213], } \\
\text { dolichol-phosphate mannosyltransferase [15837214], disulfide bond formation } \\
\text { protein B [15836942], fimbrial adhesin precursor [77747484], shikimate 5- } \\
\text { dehydrogenase [15837226], PilY1 gene product }[15837826] \text {, amino acid transporter } \\
\text { [77747501], folylpolyglutamate synthase/dihydrofolate synthase [15838540], iron- } \\
\text { sulfur cluster insertion protein ErpA [15837007], putative hydroxylase [15837200], } \\
\text { catecholate siderophore receptor Fiu [15837201], fimbrial subunit precursor } \\
\text { 15836688] }\end{array}$ \\
\hline OxyR & 15838133 & $\begin{array}{l}\text { catalase/peroxidase }[77747588] \text {, membrane-bound lytic transglycosylase } \\
{[15838775] \text {, rare lipoprotein } \mathrm{A}[15838776] \text {, fimbrial adhesin precursor }[77747484] \text {, }} \\
\text { subunit } \mathrm{C} \text { of alkyl hydroperoxide reductase }[15838131] \text {, subunit } \mathrm{F} \text { of alkyl } \\
\text { hydroperoxide reductase }[15838132] \text {, oxidative stress transcriptional regulator } \\
{[15838133]}\end{array}$ \\
\hline
\end{tabular}


Tabela 3: Descrição funcional dos fatores transcricionais para os quais os respectivos regulons foram preditos em $X$. fastidiosa a partir de dados experimentais de $E$. coli

\begin{tabular}{|c|c|}
\hline Fator transcricional & Descrição \\
\hline Fis & $\begin{array}{l}\text { Apresenta papel fundamental na regulação } \\
\text { de genes ribossomais (Ross et al., 1990) e } \\
\text { seu padrão de expressão (mRNA) já foi } \\
\text { correlacionado com genes envolvidos na } \\
\text { biossíntese flagelar, motilidade, transporte } \\
\text { de nutrientes, resposta a stress e genes } \\
\text { envolvidos na tradução(Bradley et al., 2007). }\end{array}$ \\
\hline Fur & $\begin{array}{l}\text { Atua como repressor transcricional quando } \\
\text { ligada ao íon ferro (Wee et al., 1988). Além } \\
\text { de modular a expressão de genes do } \\
\text { metabolismo de ferro também se mostrou } \\
\text { responsável por regular genes de diversos } \\
\text { processos metabólicos e, em especial, genes } \\
\text { relacionados à virulência em patógenos } \\
\text { (Zaini et al., 2008) (Lory, 1986; Luke et al., } \\
\text { 2004). }\end{array}$ \\
\hline LexA & $\begin{array}{l}\text { Atua como regulador resposta do sistema } \\
\text { sos. Seu papel é reprimir genes envolvidos } \\
\text { no reparo de DNA e, com auxílio da proteína } \\
\text { RecA, sofre autocatálise permitindo que os } \\
\text { genes do sistema sos sejam transcritos } \\
\text { (Fernandez De Henestrosa et al., 2000). }\end{array}$ \\
\hline DnaA & $\begin{array}{l}\text { Tem um papel importante na iniciação e no } \\
\text { controle da replicação cromossomal } \\
\text { (Georgopoulos, 1989). }\end{array}$ \\
\hline PurR & $\begin{array}{l}\text { Papel regulatório em um conjunto de genes } \\
\text { envolvidos na biossíntese, utilização e } \\
\text { transporte de purinas e pirimidinas (Cho et } \\
\text { al., 2011). }\end{array}$ \\
\hline NsrR & $\begin{array}{l}\text { Proteína envolvida na resposta ao estresse } \\
\text { por espécies reativas de nitrogênio (Filenko } \\
\text { et al., 2007). }\end{array}$ \\
\hline PhoP & $\begin{array}{l}\text { Regulador dual que atua em resposta ao } \\
\text { decréscimo de íons de magnésio no interior } \\
\text { celular (Monsieurs et al., 2005) e na }\end{array}$ \\
\hline
\end{tabular}




\begin{tabular}{|c|l|}
\hline CRP & $\begin{array}{l}\text { presença de peptídeos antimicrobianos } \\
\text { (Miyashiro e Goulian, 2007) }\end{array}$ \\
\hline PhoB & $\begin{array}{l}\text { Um regulador global é responsável por } \\
\text { regular a expressão de mais 100 genes em } \\
\text { E. coli, mas é universalmente conhecido } \\
\text { como regulador de genes envolvidos no } \\
\text { metabolismo de açucares alternativos à } \\
\text { glicose (Lawson et al., 2004) }\end{array}$ \\
\hline OxyR & $\begin{array}{l}\text { Ativa genes envolvidos na resposta a } \\
\text { depleção de fosfato no meio (Yamada et al., } \\
1989) .\end{array}$ \\
\hline $\begin{array}{l}\text { Induz genes envolvidos no sistema de } \\
\text { antioxidação, perante espécies reativas de } \\
\text { oxigênio (Christman et al., 1989). } \\
\end{array}$ \\
\hline
\end{tabular}

Nove dos 21 genes cujos promotores apresentam potenciais sítios reconhecidos por Fur, fator transcricional responsável por regular a expressão de genes envolvidos na homeostase de ferro (Bagg e Neilands, 1987), foram modulados em pelo menos uma condição dos experimentos de microarranjo realizados a partir de células expostas a diferentes concentrações de ferro (Zaini et al., 2008). Cinco foram super-expressos em excesso de ferro, sendo eles: 15837007 (XF0405), codificador de uma proteína envolvida na síntese de Fe-S clusters; 15837048 (XF0446), codificador de uma proteína de ligação ao DNA; 15837211 (XF0609), codificador de uma manose dehidratase; 15837214 (XF0612), codificador de uma manosiltransferase; e 15836942 (XF0340), codificador de uma proteína formadora de pontes de dissulfeto. Três foram reprimidos na mesma condição: 15837201 (XF0599), codificador de um receptor de sideróforo e cujo sítio de ligação de Fur foi experimentalmente validado; 15837226 (XF0624), codificador de uma chiquimato desidrogenase; e 15838117 (XF1516), codificador de uma proteína de mebrana exposta à superfície externa. O gene 15836688 (XF0083), codificador de um precursor de subunidade fimbrial (fimA), foi reprimido tanto em excesso como em carência de ferro.

O modelo tradicional para o funcionamento de Fur postula que genes sob sua influencia devem ser reprimidos quando na presença de íons de ferro (Wee et al., 1988). O perfil de expressão de três genes, cujos promotores apresentam potenciais motivos para Fur, segue esse padrão esperado. No entanto, cinco evidências levantadas pelo presente trabalho combinadas com os dados de expressão obtidos em (Zaini et al., 2008) sugerem que tal fator de transcrição também possa atuar como ativador em $X$. fastidiosa, embora a interação entre Fur e os sítios identificados nestes promotores careçam ainda de validação experimental. 
Estudos com Neisseria meningitidis (Delany et al., 2004), Pseudomonas aeruginosa (Wilderman et al., 2004) e Helicobacter pylori (Alamuri et al., 2006) comprovam experimentalmente a atuação de Fur como ativador direto de genes, o que suporta a factibilidade de nossa hipótese. Os genes ativados por Fur são codificantes de proteínas relacionadas à respiração aeróbica e anaeróbica em $N$. meningitidis e de uma proteína envolvida na síntese de Fe-S clusters em $H$. pylori estando, portanto, em estreita conformidade com as funções de três $(15837211,15837214,15837007)$ dos cinco genes de $X$. fastidiosa super-expressos em altas concentrações de ferro e que possuem em seus promotores potenciais motivos reconhecidos por Fur. No entanto, não é possível ainda descartar a possibilidade de mecanismos de regulação pós-transcricionais, indiretamente mediados por Fur, para explicar a superexpressão de genes em altas concentrações de ferro. Em E. coli o sRNA antisenso RhyB atua como repressor em nível pós-transcricional, porém em altas concentrações de ferro a transcrição desse sRNA é diretamente reprimida por Fur e neste caso os genes alvo de RhyB passam então a ser expressos (Masse e Gottesman, 2002). Apesar disso, a presença de motivos nos promotores dos cinco genes mencionados, a superexpressão em altas concentrações de ferro e os resultados outrora obtidos com Neisseria, Pseudomonas e Helicobacter sugerem que a ativação de alguns desses genes deva, pelo menos em parte, ocorrer devido à atuação direta de Fur e por isso merecem uma investigação mais aprofundada já que se trata de um mecanismo desconhecido em $X$. fastidiosa e pouco conhecido em bactérias em geral (Carpenter et al., 2009).

Embora não tenha sido diferencialmente expresso nos experimentos de microarranjo, o gene 15837369 (XF0767) codificante para um regulador transcricional da família ArsR chama a atenção no regulon de Fur, pois compõe uma família de reguladores envolvidos na resposta ao estresse causado por metais e pode estar envolvido em uma cascata regulatória para a homeostase de ferro e/ou outros metais. Sua sequência proteica apresenta $73 \%$ de identidade e $90 \%$ de cobertura (query coverage) com um regulador transcricional de Brucella abortus bv. 5 str. B3196, um patógeno animal (Pizarro-Cerda et al., 1998), anotado como repressor associado ao crescimento de biofilme, um importante fator de virulência em patógenos animais (Vuong et al., 2004; Hall-Stoodley e Stoodley, 2005) e vegetais (Yu et al., 1999; Ramey et al., 2004; Mole et al., 2007; Gottig et al., 2009).

O papel central de Fur como regulador transcricional, responsável por modular a expressão de genes cujas funções não se limitam ao metabolismo de ferro como, por exemplo, aqueles envolvidos na resposta ao estresse oxidativo, motilidade, patogenicidade e virulência, já é bem estabelecido (Rodionov et al., 2011). O fato de que Fur pode atuar de forma dual em algumas circunstâncias (ativador e repressor) somado às recentes constatações de que pode inclusive ser funcional em condições de carência de ferro (regulação apo-Fur) (Carpenter et al., 2009), o que poderia explicar o perfil de expressão aparentemente contraditório de fimA (reprimido em carência e excesso de ferro), reforça a ideia de que tal fator transcricional tem um papel muito mais versátil e complexo do que se acreditava e é reforçada pelas descobertas do presente trabalho.

O regulon de CRP, um regulador global tradicionalmente conhecido por modular genes envolvidos no metabolismo de açúcares alternativos à glicose (Lawson et al., 2004), apresenta genes cujos produtos estão envolvidos em diversas funções relacionadas à invasão 
e colonização do hospedeiro vegetal: 15836867 (XF0262) e 15836868 (XF0263), dois precursores de colicinas $\mathrm{V}$, toxinas diretamente envolvidas na competição celular (Riley $\mathrm{e}$ Wertz, 2002); 15837826 (XF1224) codificador de PilY1, 15839131 (XF2542) codificador de PilA, 15836636 (XF0031) codificadora de PilX, 15836633 (XF0028) codificador de FimT e 15836634 (XF0029) codificador de PilV, todos relacionados a biogênese de pilus longo do tipo IV importante para a motilidade celular (twitching motility) e formação de biofilme (Meng et al., 2005; De La Fuente et al., 2007a; De La Fuente et al., 2007b; Galvani et al., 2007; Li et al., 2007); 15837420 (XF0818) codificador de uma endoglucanase, enzima envolvida na degradação da parede celular vegetal e, portanto, relacionado à aquisição de energia e proliferação no hospedeiro vegetal; entre outras (tabela 2).

O regulon de CRP, assim como o regulon de Fur, é especialmente suportado por resultados de microarranjo realizado com células cultivadas em diferentes concentrações de glicose. Genes codificadores de PilY1; toxinas, tais como bacteriocinas e colicinas V; e proteínas de membrana envolvidas no transporte de nutrientes e toxinas foram diferencialmente expressos em pelo menos uma condição experimental (Pashalidis et al., 2005). Em especial, PilY1 e um precursor de colicina $V$ foram super-expressos em altas concentrações de glicose, ambos membros do regulon predito de CRP. Portanto, se CRP em $X$. fastidiosa, assim como em outras bactérias tal como E. coli, responder a diferentes concentrações de glicose os dados de (Pashalidis et al., 2005) reforçam os resultados aqui apresentados. Adicionalmente, a constatação de diversos genes relacionados à biogênese de pilus longo do tipo IV e nenhum relacionado à biogênese de pilus curto do tipo I nos leva a concluir que o estresse decorrente da disponibilidade de glicose e/ou outros carbohidratos que possam influenciar a atuação de CRP deve ser importante para modular a dispersão celular no meio, já que essas estruturas (pilus I e IV) contribuem, pelo menos em parte, de forma antagônica para a motilidade e adesão (Meng et al., 2005; De La Fuente et al., 2007a; De La Fuente et al., 2007b; Galvani et al., 2007; Li et al., 2007). Esta observação é corroborada pelo resultado de (Pashalidis et al., 2005) que não constatou um fenótipo mais agregativo nem a expressão diferencial de genes envolvidos na formação de biofime (como aqueles do operon gum) em altas concentrações de glicose, em contradição com o que já havia sido observado para outros fitopatógenos. Em consonância, os resultados de (Killiny e Almeida, 2009) observaram maior adesão celular, quando o meio de cultivo da cepa Temecula1 foi preparado com pectina como fonte de carbono.

Diversos genes relacionados à virulência e patogenicidade tais como celulase, colicinas, receptor de sideróforo, pili e hemaglutinina foram identificados como membros de, pelo menos, um dos regulons elucidados. Em especial, vários genes associados à biogênese de pilus longo do tipo IV, envolvido na formação de biofilme e motilidade celular, distribuídos nos regulons de LexA (pilY1), Fur (pilY1), CRP (pilA, pilY1, fimT, pilX e pilV), PhoP (pilY1), NsrR (pilA) e PhoB (pilU); e associados à biogênese de pilus curto do tipo I, envolvido na formação de biofilme e adesão celular, distribuídos nos regulons de Fur (fimA) e OxyR (fimA) (Meng et al., 2005; De La Fuente et al., 2007a; De La Fuente et al., 2007b; Galvani et al., 2007; Li et al., 2007).

Em suma, os resultados aqui apresentados (tabela 2) podem sugerir novas perspectivas sobre a biologia de $X$. fastidiosa, inclusive a respeito de sua interação com 
hospedeiros vegetais, principalmente quando associados a dados de expressão gênica em larga escala.

\subsection{Inferência $a b$ initio de motivos regulatórios - phylogenetic footprinting}

\subsubsection{Critério para identificação de unidades transcricionais ortólogas}

Um grande desafio de se aplicar a abordagem de phylogenetic footprinting para identificação de elementos cis-regulatórios em procariotos é a maneira de como lidar com os operons. Tendo isso em vista, uma análise preliminar foi aplicada para verificar a factibilidae de se identificar TUs ortólogas, ou seja, TUs reguladas por TFs ortólogos a partir do grau de conservação de suas estruturas em termos de composição gênica. Para isso, informações regulatórias de bactérias filogeneticamente relacionadas foram resgatadas de banco de dados públicos. Essas informações somadas às estruturas de operons preditas computacionalmente foram utilizados para calcular o grau de similaridade entre TUs (GS), segundo a equação 2 que designamos de classificador proposto (para mais detalhes consultar tópico 3.3.1). Os valores de GS obtidos entre TUs verdadeiramente ortólogas (conjunto dos verdadeiros) e entre TUs a principio não-ortólogas (conjunto dos falsos) foram utilizados para acessar a taxa de verdadeiros positivos e falsos positivos obtidos com diferentes valores GS de corte pré-estabelecidos

Os resultados obtidos para o par de espécies Escherichia coli K12 e Bacillus subtilis 168 são ilustrados pela figura 4.

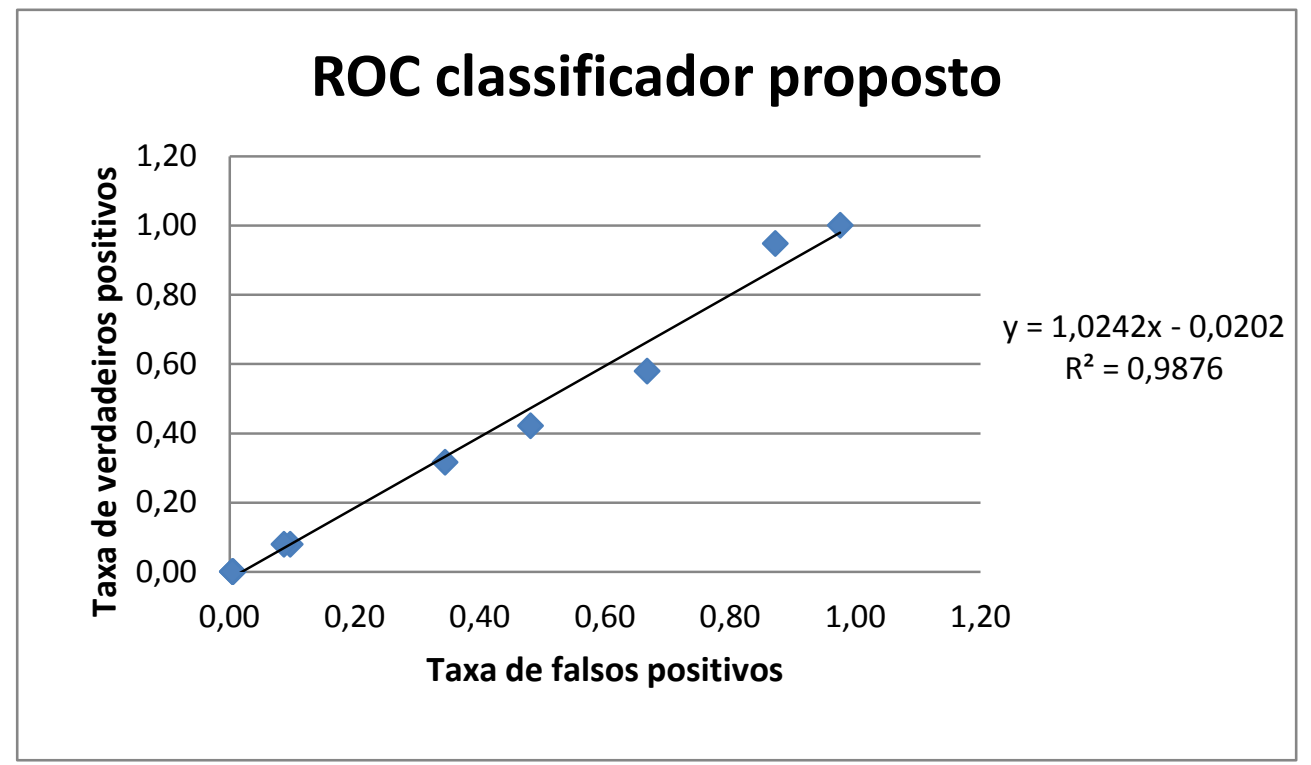

Figura 4: Curva ROC construída a partir dos valores de grau de similaridade obtidos para o conjunto dos verdadeiros e dos falsos, em $\boldsymbol{E}$. coli e B. subtilis. O grau de similaridade entre TUs que compartilham pelo menos um ortólogo foi calculado utilizando-se a equação 2. Para cada par de TUs impôs-se a restrição de que pelo menos uma deva conter mais de um gene. O eixo das abscissas $(x)$ corresponde à taxa de falsos positivos e o eixo das ordenadas $(y)$ corresponde à taxa de verdadeiros positivos. Os valores de corte de GS variaram de 0,1 a 1,0 , em janelas de 0,1 . Os pontos azuis correspondem às taxas de TUs, dentro de cada conjunto, que apresentam valor de GS igual ou superior ao valor de corte. 
A disposição linear dos pontos, o valor do coeficiente angular próximo a um e o valor do coeficiente linear próximo a zero indicam que o classificador proposto se comporta como um classificador aleatório em nosso conjunto de dados, pois as taxas de verdadeiros positivos e falsos positivos são sempre semelhantes entre si, independente do valor de corte estabelecido. Não há nenhum valor de GS que beneficie a predição de TUs do conjunto dos verdadeiros em detrimento dos falsos. Duas hipóteses são levantadas para explicar tal fenômeno:

1. O grau de similaridade entre TUs não provê evidência sobre a conservação de elementos cis-regulatórios em suas regiões promotoras.

2. O conjunto dos falsos não representa adequadamente as TUs que apresentam alguma similaridade entre si, mas que não compartilham elementos cis-regulatórios em seus promotores.

Eventos que promovem o rearranjo dos genes são frequentes ao longo da evolução dos procariotos e as estruturas dos operons se mostram bastantes instáveis até mesmo em espécies evolutivamente próximas (Itoh et al., 1999). No entanto, nota-se que o rearranjo dos genes em novos operons é de certa forma um processo conservativo, pois tende a alocar genes em contextos regulatórios e funcionais semelhantes àqueles de origem (Lathe et al., 2000; Espinosa et al., 2005) e, portanto, apesar da identidade de um operon ser corrompida ao longo da evolução alguns padrões são conservados como, por exemplo, o nível de expressão de seus genes (Price et al., 2006).

Estes fatos nos levam a dar credibilidade à segunda hipótese, pois acreditamos que muitas das modulações transcricionais ainda não elucidadas nestes organismos faça com que o conjunto dos falsos esteja superpovoado com TUs cujos graus de similaridade (GS) implicam em uma relação regulatória. A figura 5 nos mostra a distribuição dos valores de similaridade obtidos para cada conjunto e ilustra com mais clareza a homogeneidade existente entre eles. Adicionalmente, o número de pares de TUs obtidas para o conjunto dos verdadeiros é pequeno, apenas 38 , enquanto que o número de pares obtidos no conjunto dos falsos foi 703. Um número tão baixo no conjunto dos verdadeiros se deve à escassez de informações experimentais em comum para ambas as espécies e é um indício de que o conjunto dos falsos esteja de fato enriquecido com pares de TUS verdadeiramente ortólogas, causando um viés na análise. 


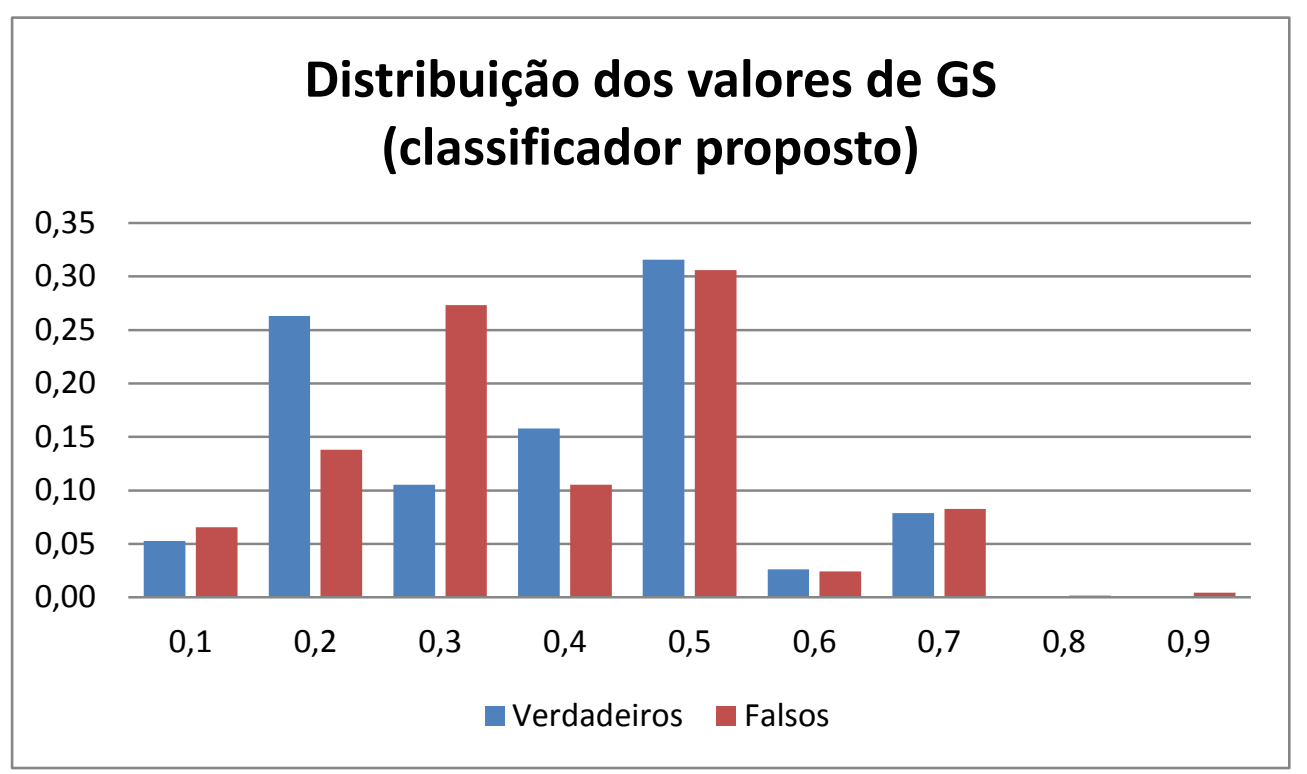

Figura 5: Distribuição dos valores de similaridade de unidades transcricionais em $E$. coli e $B$. subtilis. O grau de similaridade entre as TUs foi calculada segundo a equação 2 . As barras em azul correspondem ao conjunto de TUs reguladas por fatores de transcrição ortólogos (verdadeiros). As barras em vermelho correspondem ao restante dos pares de TUs que não foram incluídas no conjunto azul e que compartilham ao menos um ortólogo (falsos).

Os resultados obtidos para o par Escherichia coli K12 e Pseudomonas aeruginosa PAO1 foram semelhantes aos obtidos com Escherichia coli K12 e Bacillus subtilis 168 como é possível notar nas figuras 6 e 7 :

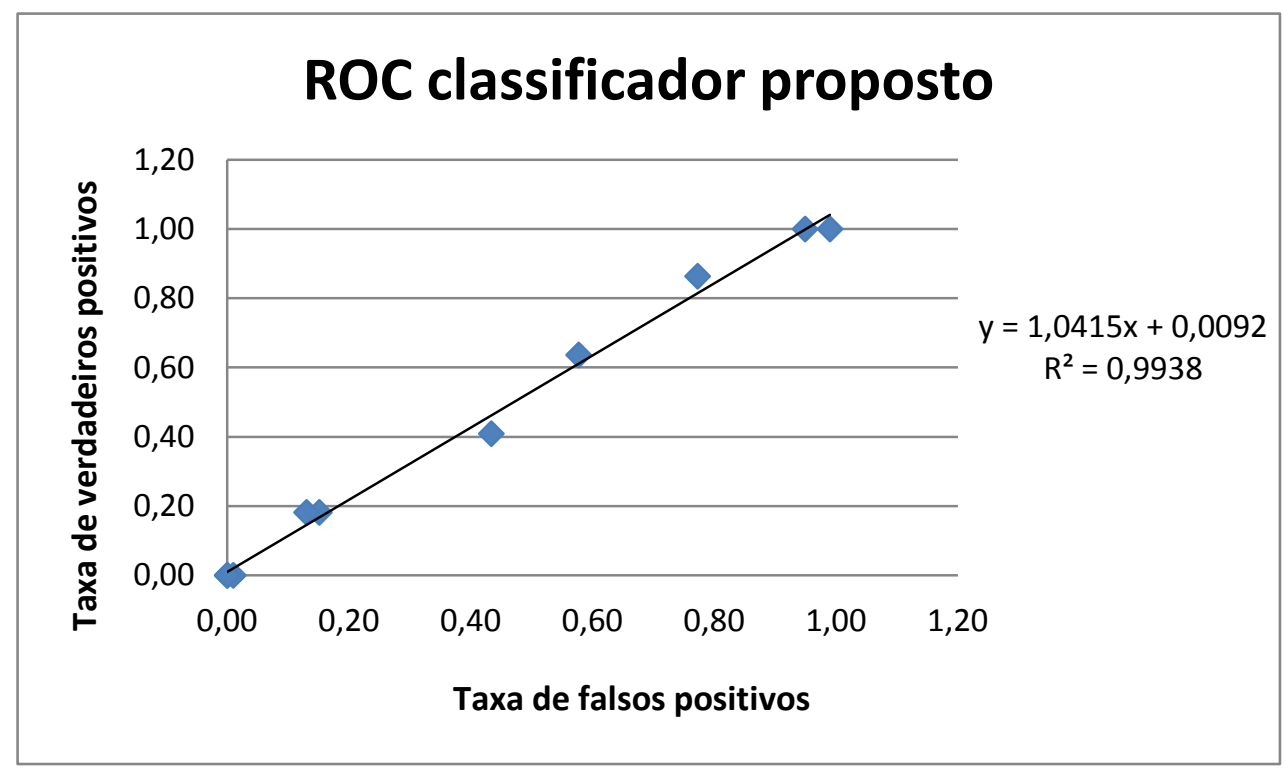

Figura 6: Curva ROC construída a partir dos valores de grau de similaridade obtidos para o conjunto dos verdadeiros e dos falsos, em $\boldsymbol{E}$. coli e $\boldsymbol{P}$. aeruginosa. O grau de similaridade entre TUs que compartilham pelo menos um ortólogo foi calculado utilizando-se a equação 2 . Para cada par de TUs impôs-se a restrição de que pelo menos uma deva conter mais de um gene. 0 eixo das abscissas (x) corresponde à taxa de falsos positivos e o eixo das ordenadas (y) corresponde à taxa de verdadeiros positivos. Os valores de corte de GS variaram de 0,1 a 1,0 , em janelas de 0,1 . Os pontos azuis correspondem às taxas de TUs, dentro de cada conjunto, que apresentam valor de GS igual ou superior ao valor de corte. 


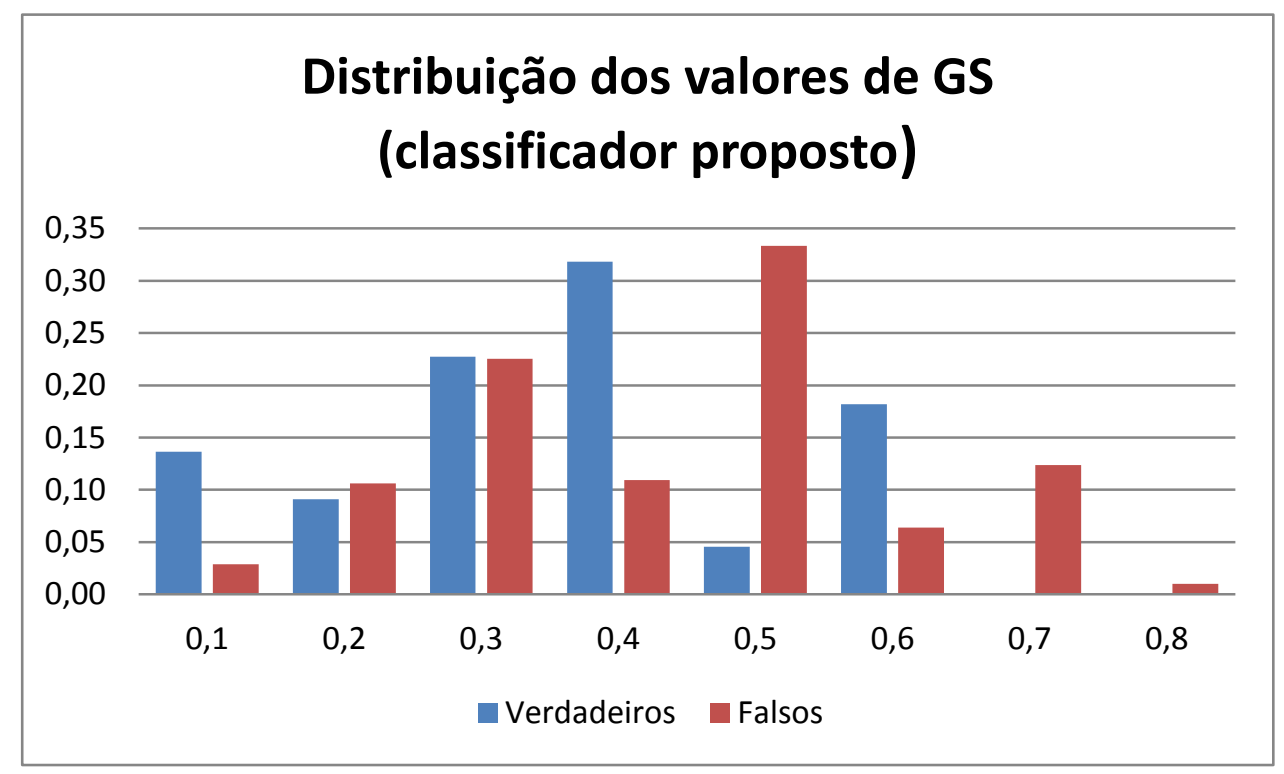

Figura 7: Distribuição dos valores de similaridade de unidades transcricionais em $E$. coli e $P$. aeruginosa. $O$ grau de similaridade entre TUs foi calculada segundo a equação 2 . As barras em azul correspondem ao conjunto de TUs reguladas por fatores de transcrição ortólogos (verdadeiros). As barras em vermelho correspondem ao restante dos pares de TUs que não foram incluídas no conjunto azul e que compartilham ao menos um ortólogo (falsos).

A falta de dados experimentais para esse par de espécies foi ainda maior. O número de pares de TUs analisado no conjunto dos falsos foi 906, já no conjunto dos verdadeiros o número atingido foi 22.

Com o intuito de avaliar o critério utilizado em (Wels et al., 2006) nós repetimos a metodologia substituindo a equação 2 pela equação 3 para calcular o grau de GS entre TUs. Os resultados obtidos para essa análise foram referidos como resultados obtidos para o classificador referência. As taxas de verdadeiros e falsos positivos e a distribuição de GS para o par de espécies Escherichia coli K12 e Bacillus subtilis 168 são apresentados nas figuras 8 e 9, respectivamente.

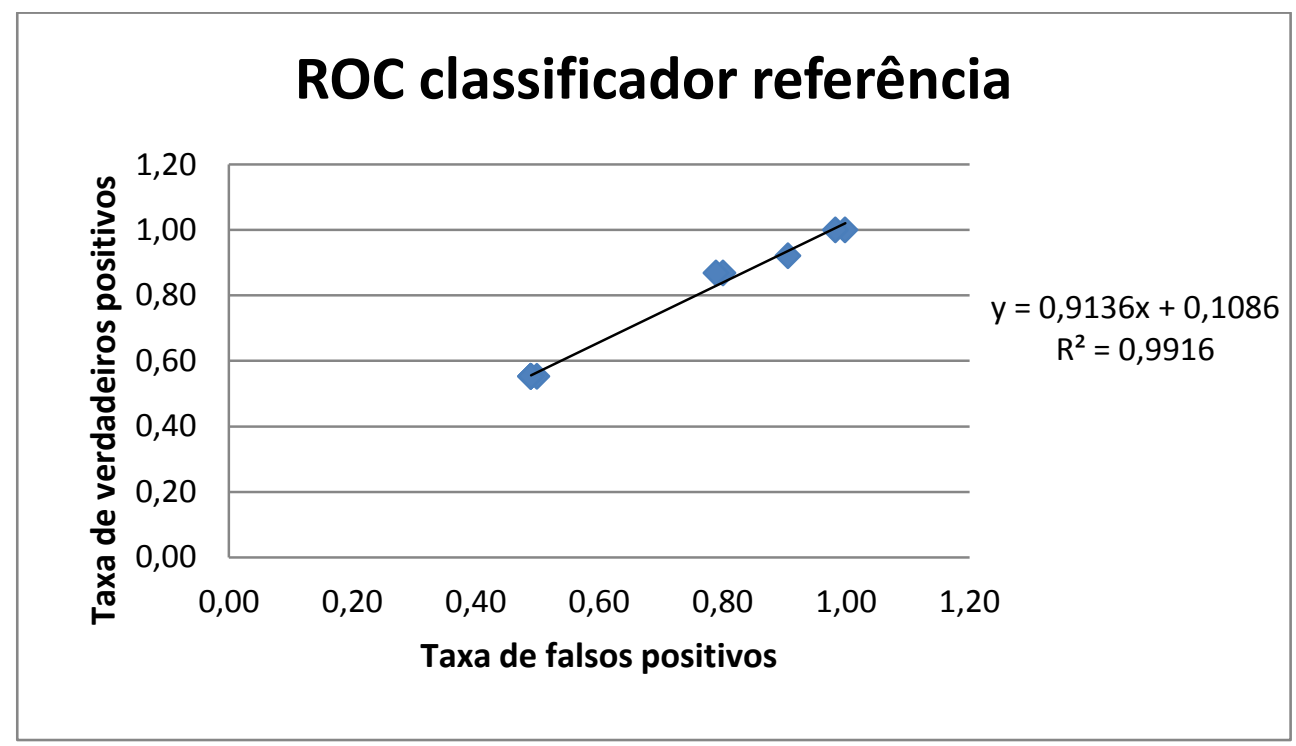

Figura 8: Curva ROC construída a partir dos valores de grau de similaridade obtidos para o conjunto dos verdadeiros e dos falsos, em $\boldsymbol{E}$. coli e B. subtilis. O grau de similaridade entre TUs que compartilham pelo menos um ortólogo foi calculado utilizando-se a equação 3 . Para cada par de TUs 
impôs-se a restrição de que pelo menos uma deva conter mais de um gene. O eixo das abscissas ( $x$ ) corresponde à taxa de falsos positivos e o eixo das ordenadas (y) corresponde à taxa de verdadeiros positivos. Os valores de corte de GS variaram de 0,1 a 1,0 , em janelas de 0,1 . Os pontos azuis correspondem às taxas de TUs, dentro de cada conjunto, que apresentam valor de GS igual ou superior ao valor de corte.

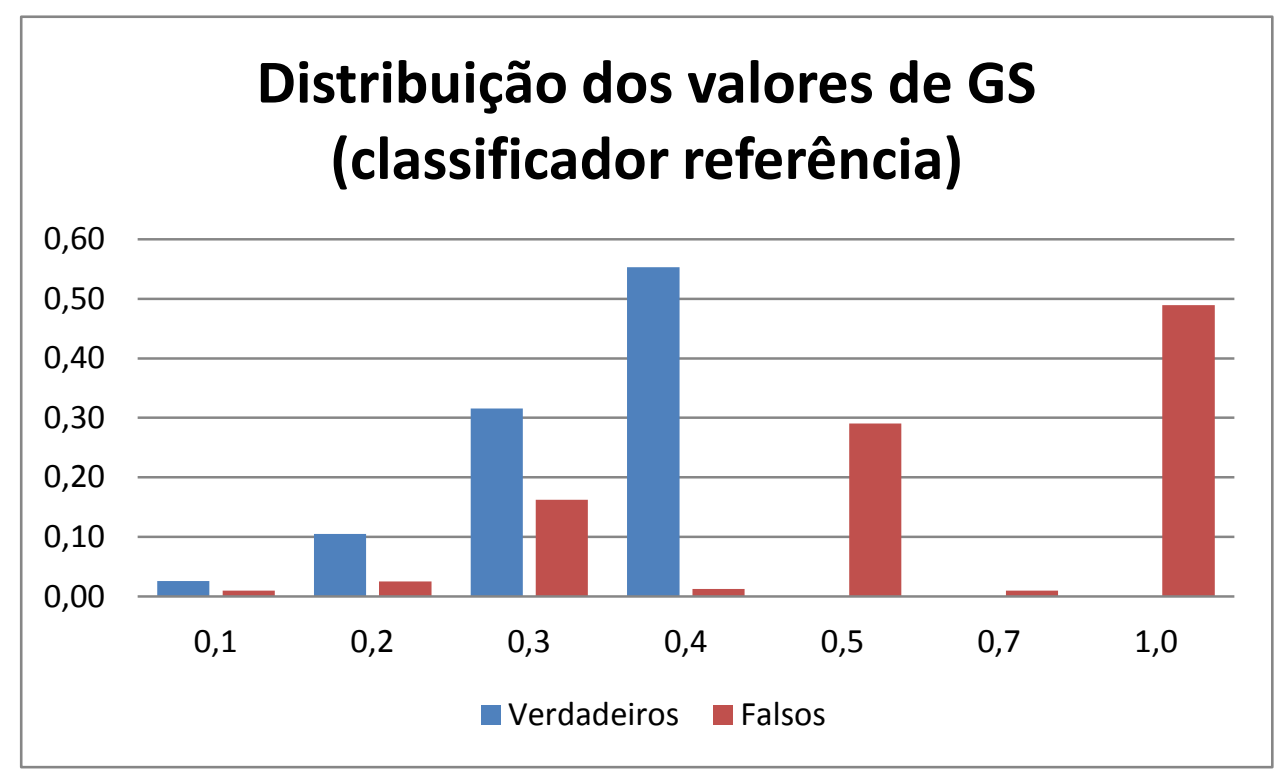

Figura 9: Distribuição dos valores de similaridade de unidades transcricionais em $E$. coli e $B$. subtilis. O grau de similaridade entre TUs foi calculada segundo a equação 3 . As barras em azul correspondem ao conjunto de TUs reguladas por fatores de transcrição ortólogos (verdadeiros). As barras em vermelho correspondem ao restante dos pares de TUs que não foram incluídas no conjunto azul e que compartilham ao menos um ortólogo (falsos).

Da mesma forma que o classificador proposto, o classificador referência se comportou como um classificador aleatório, pois as taxas de verdadeiros positivos e falsos positivos são sempre semelhantes, independente do valor de corte estabelecido (figura 8). A diferença que é possível observar entre os dois classificadores é que quando os valores de similaridade (GS) são calculados com base no classificador proposto as frequências obtidas para os diferentes valores de GS são mais homogêneas entre si, ou seja, a distribuição de GS não se concentra em um intervalo (faixa) estreito de valores como é possível observar quando empregamos o classificador referência. Isto é uma constatação interessante, pois indica que o ganho e/ou perda de genes sofrida por duas TUs desde o momento em que divergiram é de fato uma característica informativa para classificar a similaridade entre elas. Esta constatação somada à noção de que a realocação de genes em diferentes TUs determina o contexto regulatório em que tais genes são expressos foram fatores determinantes para optarmos pelo classificador proposto para identificação de potenciais TUs ortólogas nas predições ab initio de motivos regulatórios.

Os resultados obtidos com Escherichia coli K12 e Pseudomonas aeruginosa PAO1 são apresentados nas figuras 10 e 11 : 


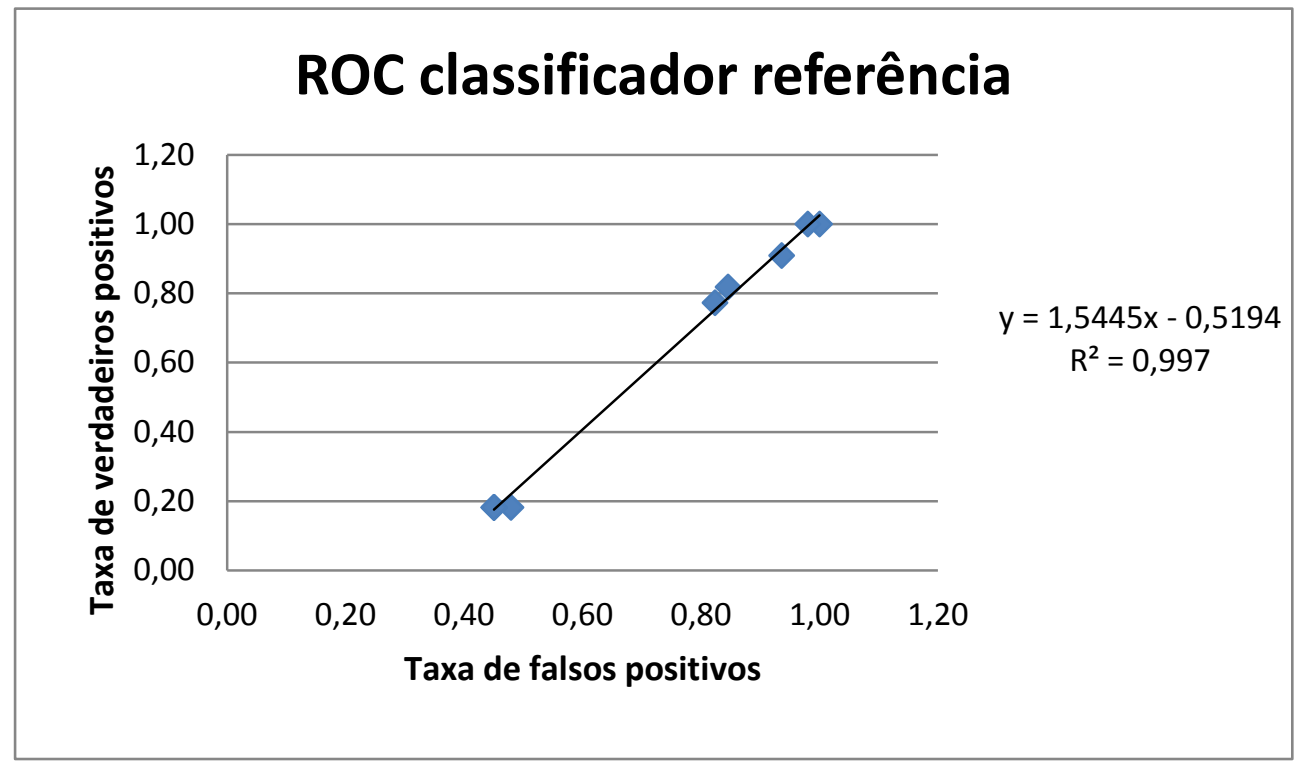

Figura 10: Curva ROC construída a partir dos valores de grau de similaridade obtidos para o conjunto de verdadeiros e dos falsos, em $\boldsymbol{E}$. coli e $\boldsymbol{P}$. aeruginosa. O grau de similaridade entre TUs que compartilham pelo menos um ortólogo foi calculado utilizando-se a equação 3. Para cada par de TUs impôs-se a restrição de que pelo menos uma deva conter mais de um gene. O eixo das abscissas $(x)$ corresponde à taxa de falsos positivos e o eixo das ordenadas (y) corresponde à taxa de verdadeiros positivos. Os valores de corte de GS variaram de 0,1 a 1,0 , em janelas de 0,1 . Os pontos azuis correspondem às taxas de TUs, dentro de cada conjunto, que apresentam valor de GS igual ou superior ao valor de corte.

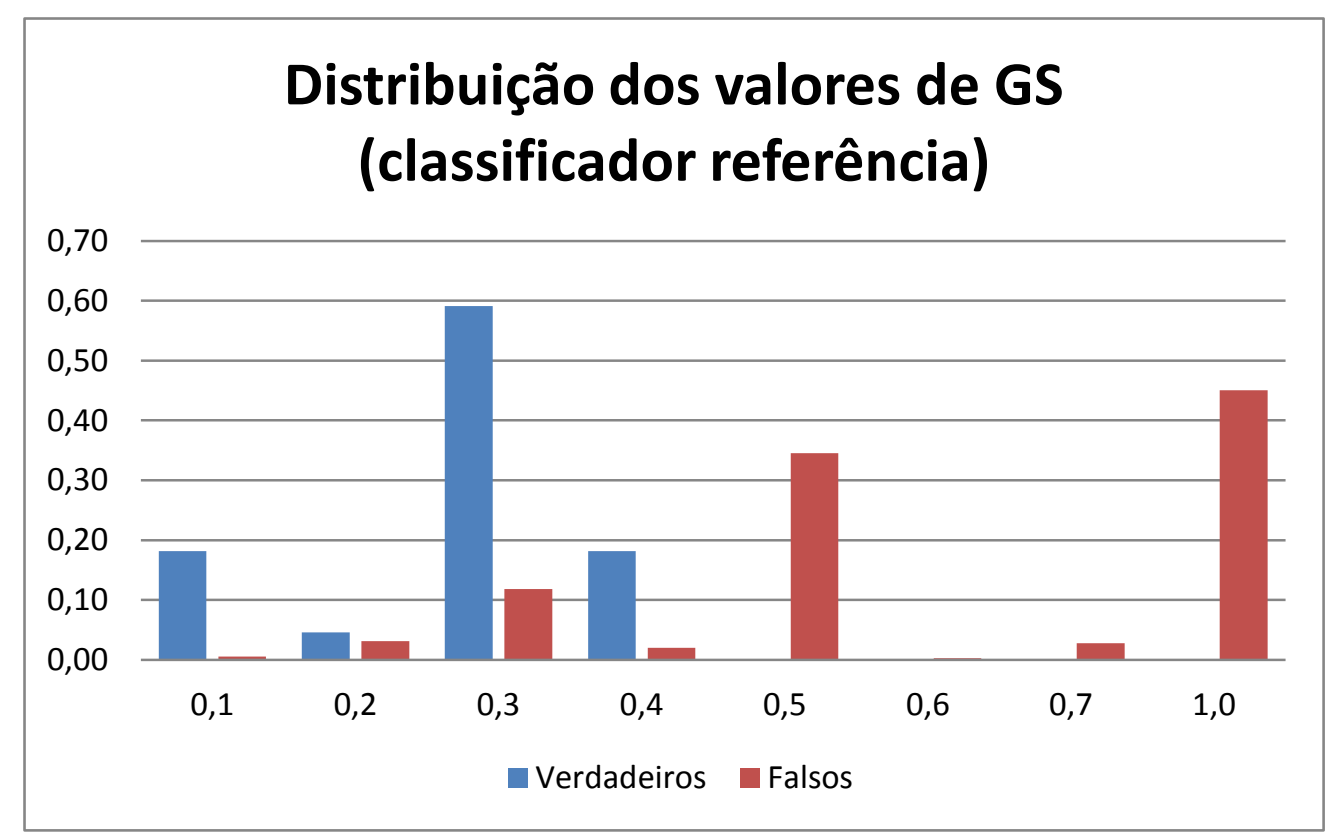

Figura 11: Distribuição dos valores de similaridade de unidades transcricionais em $E$. coli e $P$. aeruginosa. O grau de similaridade entre TUs foi calculada segundo a equação 3 . As barras em azul correspondem ao conjunto de TUs reguladas por fatores de transcrição ortólogos (verdadeiros). As barras em vermelho correspondem ao restante dos pares de TUs que não foram incluídas no conjunto azul e que compartilham ao menos um ortólogo (falsos).

Para este par de espécies fica claro que a falta de dados e a falta de um conjunto de falsos mais confiável provocaram um viés nos resultados, pois o conjunto de falsos possui 
altas frequências em valores altos de GS $(0,5$ e 1,0) enquanto que as maiores frequências de GS do conjunto de verdadeiros se concentra em valores baixos $(0,1 ; 0,3$ e 0,4$)$. 0 oposto seria o esperado já que quanto maior o GS, mais similares são as TUs comparadas. Vale ressaltar que as TUs incluidas nas análises do classificador referência são as mesmas utilizadas nas análises do classificador proposto.

Podemos notar, observando as barras vermelhas das figuras 5 e 7 , que a distribuição dos valores de similaridade calculados a partir da equação 2 (classificador proposto) parece ser influenciada pela distância filogenética subjacente ao par de espécies comparadas. A proporção de valores altos de GS é maior nas espécies mais próximas ( $E$. coli e $P$. aeruginosa).

Uma vez que o conjunto dos falsos (barras vermelhas das figuras) representa a maioria das relações de similaridade entre as TUs $(94,6 \%$ em $E$. coli e B. subtilis e $97,6 \%$ em $E$. coli e $P$. aeruginosa) resolvemos investigar se tal influência seria reproduzida utilizando-se outras espécies. Por isso calculamos a distribuição dos valores de similaridade entre as TUs de Xylella fastidiosa 9a5c e cada uma das seguintes espécies, utilizadas posteriormente para predição ab initio de motivos cis-regulatórios (tópico 4.2.2, tabela 4): Dickeya dadantii Ech586, Erwinia amylovora CFBP1430, Pectobacterium carotovorum subsp. carotovorum PC1, Pseudomonas syringae pv. tomato str. DC3000, Ralstonia solanacearum CFBP2957, Stenotrophomonas maltophilia R551-3, Xanthomonas axonopodis pv. citri str. 306. Os resultados obtidos são apresentados na figura 12.

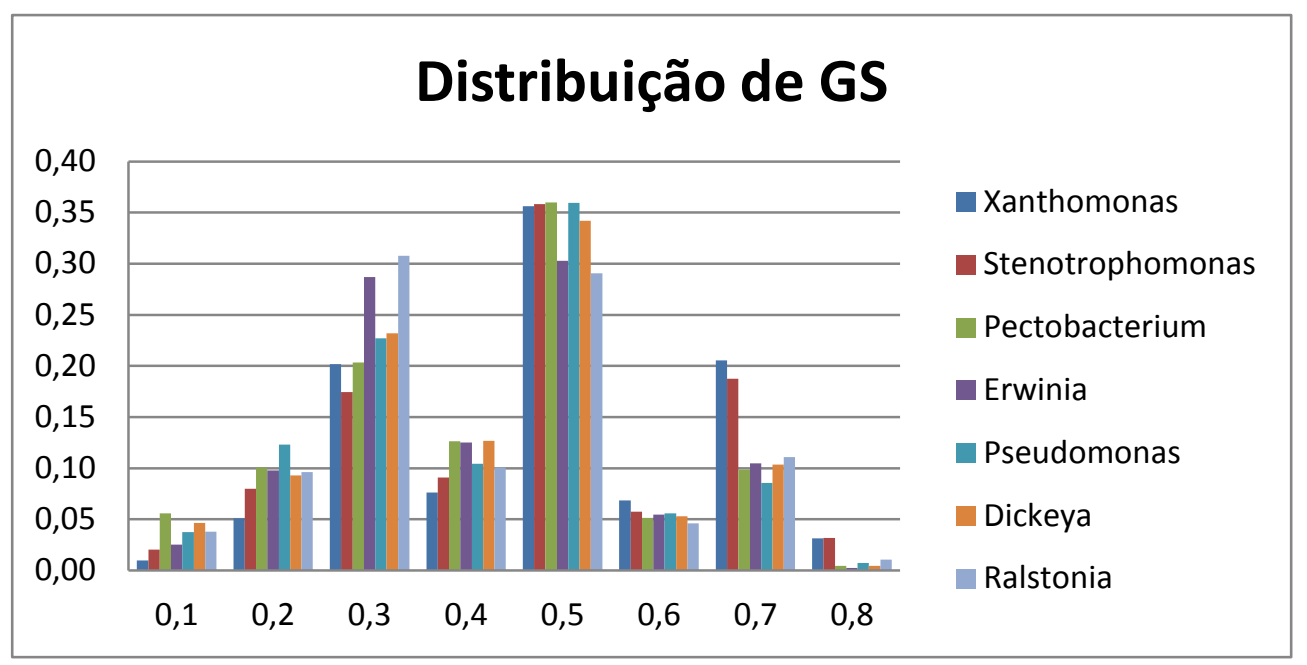

Figura 12: Distribuição dos valores de similaridade das unidades transcricionais de $X$. fastidiosa em relação às unidades transcricionais das espécies comparativas utilizadas para predição ab initio de motivos cis-regulatórios. O grau de similaridade entre as TUs que compartilham pelo menos um ortólogo foi calculado segundo a equação 2 (classificador proposto). A cada par de TUs comparadas impôs-se a restrição de que pelo menos deva conter mais de um gene em sua composição.

Os resultados reforçam a influência do par de espécies comparadas na distribuição dos valores de GS, pois espécies da família Xanthomonadaceae (Stenotrophomonas maltophilia e Xanthomonas axonopodis) são aquelas que apresentam uma maior proporção de TUs cujos valores de GS é igual ou superior a 0,7. Já em espécies filogeneticamente mais 
distantes a $X$. fastidiosa, a proporção de valores menores de GS tende a aumentar. Este resultado reforça a ideia de que o grau de similaridade entre estruturas de operons pode dar pistas sobre a relação filogenética entre os pares de espécies comparados (Tamames, 2001; Rogozin et al., 2004; Belda et al., 2005).

Pode-se notar também que as massas de GS se concentram, na maioria dos casos, em torno de 0,3 e 0,5. Para explicar esse fenômeno sugerimos a hipótese de que existe uma força evolutiva que favorece a mudança da organização dos genes em diferentes estruturas transcricionais, já que poucas unidades apresentam alto grau de conservação, o que provavelmente contribui para alocação de genes em contextos regulatórios onde o balanço entre a expressão gênica e o consequente gasto energético é otimizado para o nicho ecológico que a linhagem ocupa. Em contrapartida, as mudanças mais extremas não persistem na população (baixa frequência de alto GS), pois provavelmente implicam na alocação dos genes em contextos funcionais e/ou regulatórios incompatíveis e acabam se tornando deletérias para a célula. No entanto, uma análise mais detalhada com um conjunto de espécies que apresentam distâncias evolutivas mais variadas entre si é necessária para corroborar esta hipótese.

Finalmente, na ausência de resultados que pudessem indicar um critério adequado para identificação de TUs ortólogas, utilizamos o critério de GS maior ou igual a 0.5 para selecionar pares de TUs potencialmente ortólogas, calculado conforme a equação 2 (classificador proposto).

\subsubsection{Motivos regulatórios preditos - regulons ab initio}

O passo inicial para identificação de motivos cis-regulatórios pela abordagem de phylogentic footprinting foi a seleção do conjunto de espécies comparativas das quais derivamos posteriormente os grupos de TUs ortólogas. As espécies selecionadas e as respectivas características consideradas relevantes para análises desse gênero estão dispostas na tabela 4 (McCue et al., 2002; Espinosa et al., 2005; Zhang et al., 2009).

As proporções de genes e TFs ortólogos foram consideradas as características mais relevantes para a inclusão ou não de uma espécie no conjunto, pois se presume que se o par TF e gene regulado está conservado em duas espécies também deve estar o elemento cisregulatório envolvido na modulação.

Em uma etapa de pré-seleção, as espécies candidatas foram escolhidas com base nas outras características: habitat de onde foi isolada, número de ORFs, tamanho genômico em pares de bases e preferencialmente inseridas no táxon das proteobacterias do tipo gama. No entanto, uma proteobacteria do tipo beta, Ralstonia solanacearum, chamou nossa atenção, pois dentre todas as outras era a que mais se assemelhava à $X$. fastidiosa em termos de tamanho genômico, número de ORFs e habitat de isolamento (também coloniza o xilema vegetal), características de extrema importância para análises de phylogenetic footprinting (McCue et al., 2002). As análises de ortologia justificaram a inclusão da Ralstonia solanacearum no grupo de espécies comparativas, pois as proporções de genes e 
TFs ortólogos estão acima dos mínimos estipulados (tabela 4), 30\% para genes e $25 \%$ para TFs.

As sequências dos promotores de cada grupo de TUs ortólogas, derivadas a partir de $X$. fastidiosa e do conjunto de espécies comparativas, foram submetidas às ferramentas BioProspector, MotifSampler, Phylogibbs e MEME. Esta última em duas configurações distintas, uma para predição de motivos palindrômicos e outra para motivos não palindrômicos. Após a seleção dos motivos com maiores chances de serem funcionais, ou seja, aqueles que foram preditos pelo maior número de ferramentas (ou com maior valor de IC em caso de empate), obtivemos um total de 829 predições, um motivo para cada grupo de TUs ortólogas, sendo que a contribuição de cada ferramenta para esse valor está representada na figura 13 :

\section{Proporção das predições selecionadas}

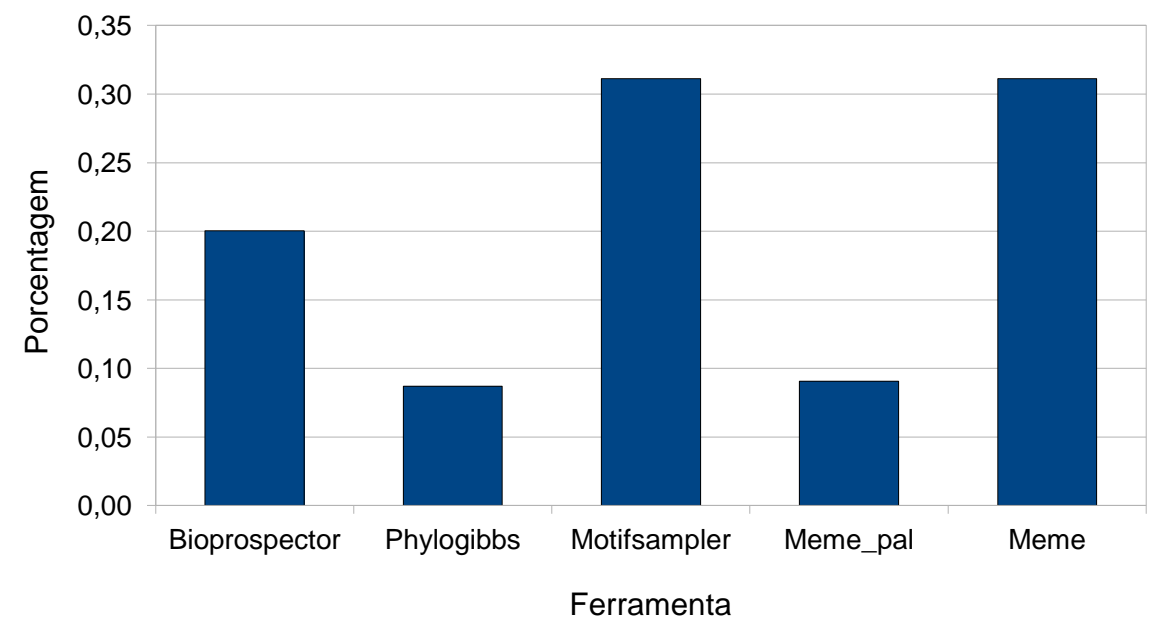

Figura 13: Contribuição de cada ferramenta para predição dos elementos cis-regulatórios selecionados.

Variando-se o valor de GS para 1, na etapa de identificação de TUs ortólogas, 0 número total de motivos preditos foi 629. TUs com valores de GS igual a 1 correspondem a TUs cujos conteúdos gênicos são idênticos entre si sendo, portanto, um valor de corte que julgamos conservativo demais para o presente estudo, pois ocasionaria uma redução considerável na amostragem de TUs potencialmente ortólogas (aproximadamente 25\%). 
Tabela 4: Conjunto de espécies para a análise comparativa.

\begin{tabular}{|c|c|c|c|c|c|c|c|c|}
\hline Espécie & $\begin{array}{c}\text { Xylella fastidiosa } \\
9 a 5 c\end{array}$ & $\begin{array}{l}\text { Xanthomonas } \\
\text { axonopodis } \\
\text { pv. citri str. } 306\end{array}$ & $\begin{array}{l}\text { Stenotrophomonas } \\
\text { maltophilia R551-3 }\end{array}$ & $\begin{array}{c}\text { Pseudomonas } \\
\text { syringae pv.tomato } \\
\text { str. DC3000 }\end{array}$ & $\begin{array}{c}\text { Pectobacterium } \\
\text { carotovorum subsp. } \\
\text { carotovorum PC1 }\end{array}$ & $\begin{array}{c}\text { Ralstonia } \\
\text { solanacearum } \\
\text { CFBP2957 } \\
\end{array}$ & $\begin{array}{c}\text { Dickeya dadantii } \\
\text { Ech586 }\end{array}$ & $\begin{array}{c}\text { Erwinia } \\
\text { amylovora } \\
\text { CFBP1430 }\end{array}$ \\
\hline $\begin{array}{c}\text { Tamanho do } \\
\text { genoma(número } \\
\text { de pares de bases } \\
\text { no cromossomo) } \\
\end{array}$ & 2679306 & 5175554 & 4573969 & 6397126 & 4862913 & 3417386 & 4818394 & 3805573 \\
\hline Número de ORFs & 2766 & 4312 & 4039 & 5481 & 4246 & 3223 & 4144 & 3677 \\
\hline Taxonomia & $\begin{array}{c}\text { Bacteria; } \\
\text { Proteobacteria; } \\
\text { Gammaproteobacteria; } \\
\text { Xanthomonadales; } \\
\text { Xanthomonadaceae; } \\
\text { Xylella; } \\
\text { Xylella fastidiosa; } \\
\text { Xylella fastidiosa 9a5c }\end{array}$ & $\begin{array}{c}\text { Bacteria; } \\
\text { Proteobacteria; } \\
\text { Gammaaproteobacteria; } \\
\text { Xanthomonadales; } \\
\text { Xanthomonadaceae; } \\
\text { Xanthomonas; } \\
\text { Xanthomonas } \\
\text { axonopodis; } \\
\text { Xanthomonas } \\
\text { axonopodis pv. Citri; } \\
\text { Xanthomonas } \\
\text { axonopodis pv. citri str. } \\
\text { 306 } \\
\end{array}$ & $\begin{array}{c}\text { Bacteria; } \\
\text { Proteobacteria; } \\
\text { Gammaproteoobacteria; } \\
\text { Xanthomonadales; } \\
\text { Xanthomonadaceae; } \\
\text { Stenotrophomonas; } \\
\text { Stenotrophomonas maltophilia } \\
\text { group; } \\
\text { Stenotrophomonas } \\
\text { maltohilia; } \\
\text { Stenotrophomonas maltophilia } \\
\text { R551-3 } \\
\end{array}$ & $\begin{array}{c}\text { Bacteria; } \\
\text { Proteobacteria; } \\
\text { Gammaproteobacteria; } \\
\text { Pseudomonadales; } \\
\text { Pseudomonadaceae; } \\
\text { Pseudomonas; } \\
\text { Pseudomonas syringae } \\
\text { pv. tomato str. DC3000 }\end{array}$ & $\begin{array}{c}\text { Bacteria; } \\
\text { Proteobacteria; } \\
\text { Gammaproteobacteria; } \\
\text { Enterobacteriales; } \\
\text { Enterobacteriaceae; } \\
\text { Pectobacterium; } \\
\text { Pectobacterium carotovorum; } \\
\text { Pectobacterium carotovorum subsp. } \\
\text { Carotovorum; } \\
\text { Pectobacterium carotovorum subsp. } \\
\text { carotovorum PC1 }\end{array}$ & $\begin{array}{c}\text { Bacteria; } \\
\text { Proteobacteria; } \\
\text { Betaproteobacteria; } \\
\text { Burkholderiales; } \\
\text { Burkholderiaceae; } \\
\text { Ralstonia; } \\
\text { Ralstonia solanacearum; } \\
\text { Ralstonia solanacearum } \\
\text { CFBP2957 }\end{array}$ & $\begin{array}{c}\text { Bacteria; } \\
\text { Proteobacteria; } \\
\text { Gammaproteobacteria; } \\
\text { Enterobacteriales; } \\
\text { Enterobacteriaceae; } \\
\text { Dickeya; } \\
\text { Dickeya dadanti; } \\
\text { Dickeya dadantii } \\
\text { Ech586 }\end{array}$ & $\begin{array}{c}\text { Bacteria; } \\
\text { Proteobacteria; } \\
\text { Gammaproteobacteria; } \\
\text { Enterobacteriales; } \\
\text { Enterobacteriaceae; } \\
\text { Erwinia; } \\
\text { Erwinia amylovora; } \\
\text { Erwinia amylovora } \\
\text { CFBP1430 }\end{array}$ \\
\hline Habitat & $\begin{array}{l}\text { Fitopatógeno de } \\
\text { citros; habita } \\
\text { xilema da planta } \\
\text { e cibário do } \\
\text { inseto vetor } \\
\text { (cigarrinha) } \\
\end{array}$ & $\begin{array}{l}\text { Fitopatógeno de } \\
\text { citros; agente } \\
\text { causador do } \\
\text { câncro cítrico }\end{array}$ & $\begin{array}{l}\text { Endofítica isolada de } \\
\text { Populus trichocarpa }\end{array}$ & $\begin{array}{l}\text { Fitopatógeno de } \\
\text { tomateiro }\end{array}$ & $\begin{array}{l}\text { Fitopatógeno;agente } \\
\text { causador de soft rot } \\
\text { disease em vários } \\
\text { hospedeiros }\end{array}$ & $\begin{array}{l}\text { Fitopatógeno de } \\
\text { tomateiro; } \\
\text { habita xilema do } \\
\text { hospedeiro }\end{array}$ & $\begin{array}{c}\text { Fitopatógeno; } \\
\text { causador de soft rot } \\
\text { disease em diversos } \\
\text { hospedeiros }\end{array}$ & $\begin{array}{c}\text { Fitopatógeno de } \\
\text { macieiras e } \\
\text { pereiras; } \\
\text { causador do Fire } \\
\text { Blight }\end{array}$ \\
\hline $\begin{array}{l}\text { Número total de } \\
\text { ortólogos } \\
\text { encontrados em } \\
X . \text { fastidiosa } \\
\end{array}$ & & 1491 & 1428 & 1105 & 999 & 962 & 1001 & 938 \\
\hline $\begin{array}{c}\text { Proporção de } \\
\text { genes de } X \text {. } \\
\text { fastidiosa que foi } \\
\text { possível a } \\
\text { identificação de } \\
\text { ortólogo } \\
\end{array}$ & & $53,90 \%$ & $51,63 \%$ & $39,95 \%$ & $36,12 \%$ & $34,78 \%$ & $36,19 \%$ & $33,91 \%$ \\
\hline $\begin{array}{l}\text { Número total de } \\
\text { TFs de } X . \\
\text { fastidiosa que foi } \\
\text { possível a } \\
\text { identificação de } \\
\text { ortólogo } \\
\end{array}$ & & 39 & 36 & 29 & 27 & 24 & 23 & 21 \\
\hline $\begin{array}{c}\text { Proporção de TFs } \\
\text { de } X \text {. fastidiosa } \\
\text { que foi possível a } \\
\text { identificação de } \\
\text { ortólogo }\end{array}$ & & $59,09 \%$ & $54,55 \%$ & $43,94 \%$ & $40,91 \%$ & $36,36 \%$ & $34,85 \%$ & $31,82 \%$ \\
\hline
\end{tabular}


Em seguida as matrizes representantes dos 829 motivos foram utilizadas para varrer as sequências inter-TUs de $X$. fastidiosa com o intuito de identificarmos instâncias adicionais dos motivos preditos, pois em geral espera-se que um fator transcricional regule mais do que apenas uma TU (GuhaThakurta, 2006; Rodionov, 2007; van Hijum et al., 2009). A ferramenta utilizada para tal tarefa, MAST (Bailey e Gribskov, 1998), associa a cada hit um p-valor. Para filtrar possíveis hits não funcionais e tornar a análise mais robusta definimos um p-valor de corte nos baseando na premissa de que a maioria dos sítios de ligação de fatores transcicionais estão localizados em regiões não codificantes (inter-TUs). Por isso, as regiões codificantes de proteínas, excluindo-se aquelas anotadas como hipotéticas, também foram varridas em busca de instâncias adicionais. As frações de hits obtidos nas regiões inter-TUs e nas regiões codificantes estão graficamente representadas na figura 14, para diferentes p-valores.

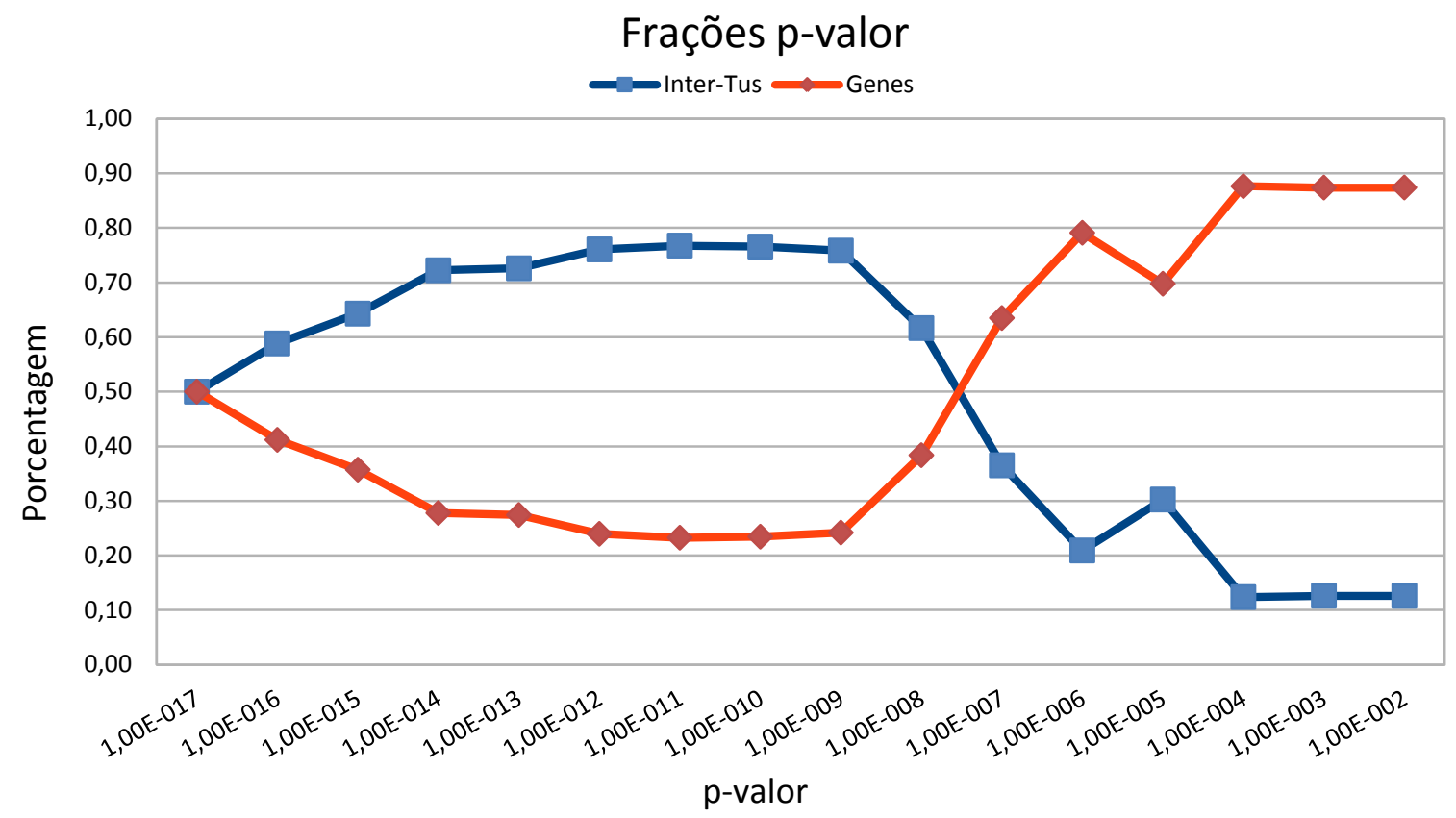

Figura 14: Fração de hits (instâncias) localizados nas regiões inter-TUs (linha azul) e nas regiões codificantes de proteínas (linha laranja). As matrizes correspondentes aos motivos preditos foram utilizadas como input da ferramenta MAST para identificação de de instâncias adicionais destes motivos, tanto em regiões inter-TUs como em regiões codificantes, excluindo-se os genes anotados como hipotéticos. As frações de hits obtidas com cada p-valor estão representadas.

A partir dos resultados dessa análise definimos um valor de corte que beneficiaria a identificação de instâncias nas regiões inter-TUs em detrimento às regiões codificantes e que ao mesmo tempo preservasse ao máximo o número de hits das regiões inter-TUs. O valor escolhido foi $1,00 \mathrm{E}^{-08}$ para o qual as proporções de hits em regiões codificantes e inter-TUs foram, $38 \%$ e $62 \%$ respectivamente (figura 14 ).

O número de pares de bases das regiões codificantes utilizado para esta etapa se mostrou muito maior que o número de pares de bases das regiões inter-TUs e por isso a expectativa de hits ao acaso em regiões codificantes é naturalmente maior, tornando a 
comparação direta das proporções de hits em cada conjunto de dados desleal. Ao normalizarmos os resultados pelo número total de hits obtidos em cada conjunto de sequências (codificante e inter-TUs), notamos que o valor de corte estabelecido identifica aproximadamente 11 instâncias em região inter-TUs para cada instância identificada em região codificante (figura 15). Vale mencionar que se um valor de corte mais restritivo (menor p-valor) fosse utilizado somente as instâncias mais conservadas seriam consideradas para as etapas seguintes e, consequentemente, aquelas com maior grau de degeneração, mas nem por isso sem funcionalidade biológica, seriam descartadas. A degeneração aparenta ser uma característica predominante de motivos cis-regulatórios e pode, inclusive, ter um papel fundamental para o controle racional da expressão de diferentes unidades transcricionais moduladas por um mesmo fator transcricional (Stormo, 2000; van Hijum et al., 2009), justificando o critério de corte estabelecido pelo presente trabalho.

\section{Relação de predição (Inter-TUs/Genes)}

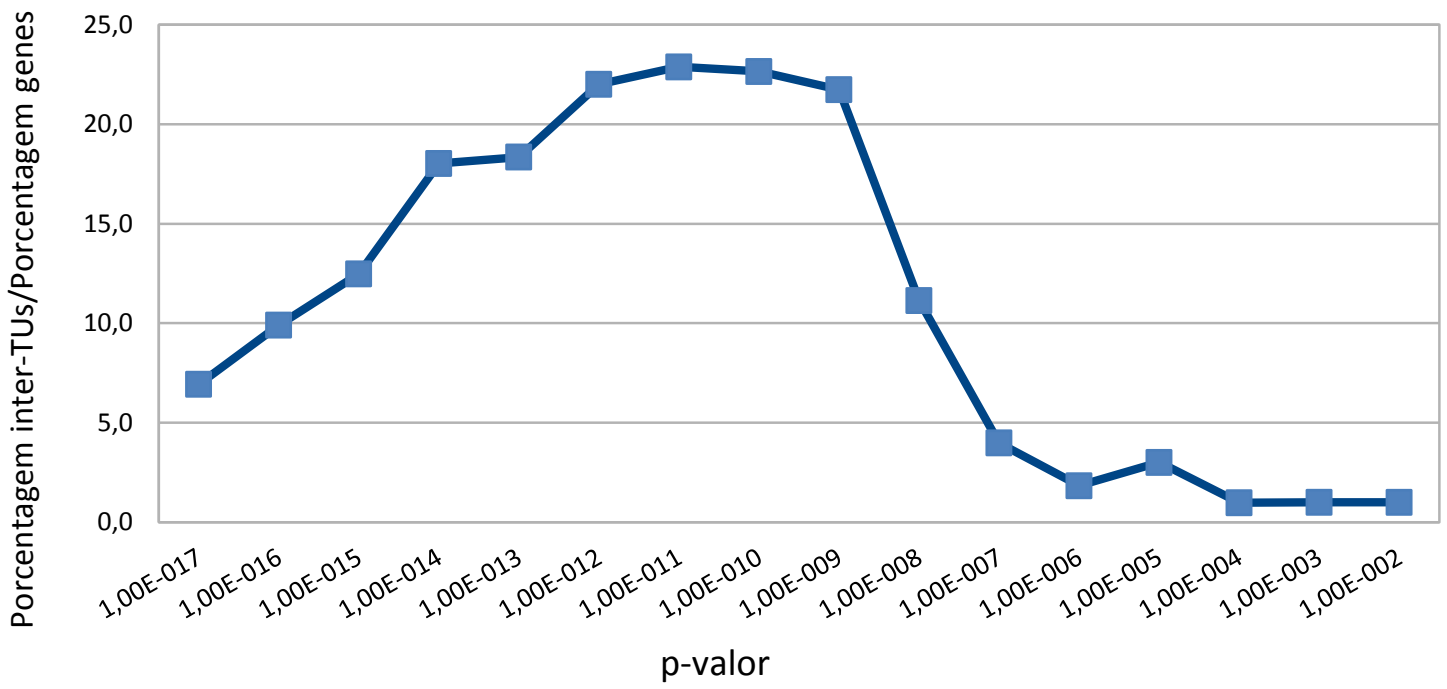

Figura 15: Relação do número normalizado de hits em regiões inter-TUs pelo número normalizado de hits em regiões codificantes. As matrizes correspondentes aos motivos preditos foram utilizadas como input da ferramenta MAST para identificação de instâncias adicionais destes motivos, tanto em regiões inter-TUs como em regiões codificantes (sem hipotéticos). As frações normalizadas de hits obtidas com cada p-valor estão representadas.

As instâncias das regiões inter-TUs de um mesmo motivo que satisfizeram o valor de corte estabelecido foram capturadas e alinhadas para dar origem às matrizes Xylella específicas, com a condição de que cada matriz deva ser composta por, no mínimo, 4 instâncias (hits). O número total de matrizes Xylella específicas geradas foi 80. Uma queda tão grande, de 829 para 80 , se deve ao fato de que muitos dos motivos não apresentaram o número mínimo de hits (4 hits) que satisfizessem o valor de corte. 
As matrizes Xylella específicas foram então utilizadas para varrer novamente as regiões inter-TUs e, com base nos hits obtidos, definimos o conjunto de TUs que compõe o regulon de cada um dos 80 motivos. Foi possível identificar ao menos um elemento cisregulatório (instância) em 56.2\% das TUs (991 de 1763) sendo que $24.2 \%$ (427 TUs) apresentam instâncias para dois ou mais motivos em seus promotores, ou seja, são putativamente reguladas por mais de um fator trans-atuante, valor próximo dos $31 \%$ observado em $E$. coli a partir de interações regulatórias experimentalmente validadas (van Hijum et al., 2009). A distribuição do número de diferentes motivos que co-ocorrem em uma mesma TU está representada na figura 17.

A partir da figura 16 observamos que a distribuição do número de TUs por regulon, isto é, a distribuição dos tamanhos dos regulons preditos, se aproxima de uma normal com a cauda direita alongada (skew 1.26). O valor mínimo, máximo e a mediana para o tamanho dos regulons são 3, 134 e 33.5, respectivamente. Exemplos de TFs que modulam a expressão de diversas TUs são conhecidos. Em E. coli, por exemplo, o maior regulon que se tem conhecimento é o de CRP, responsável por modular a expressão de pelo menos 230 TUs (Zhang et al., 2012). No total foram inferidas 2990 interações regulatórias que equivalem à somatória do número de TUs presentes no regulon de cada um dos 80 motivos preditos, das quais $10 \%$ dos motivos (8) são responsáveis por aproximadamente $25 \%$ do total de interações inferidas (743).

Com base nos resultados apresentados e tendo em vista o critério estabelecido para definição dos regulons (no mínimo 4 instâncias regulatórias) sugerimos, portanto, que a maioria dos TFs em $X$. fastidiosa atua em escala local, sendo responsável por regular a expressão de um conjunto limitado de genes que geralmente estão dispostos no cromossomo em proximidade ao gene do TF regulador (vizinhos próximos). Enquanto isso, poucos TFs atuam de forma global, responsáveis pela maioria das interações regulatórias ao afetar a expressão de diversos genes dispersos no cromossomo (vizinhos distantes). Estas observações estão em conformidade com as propriedades das redes regulatórias de bactérias modelo tais como E. coli (Martinez-Antonio e Collado-Vides, 2003; Yu e Gerstein, 2006; Karp et al., 2007) e B. subtilis (Fadda et al., 2009). 
Tamanho dos Regulons

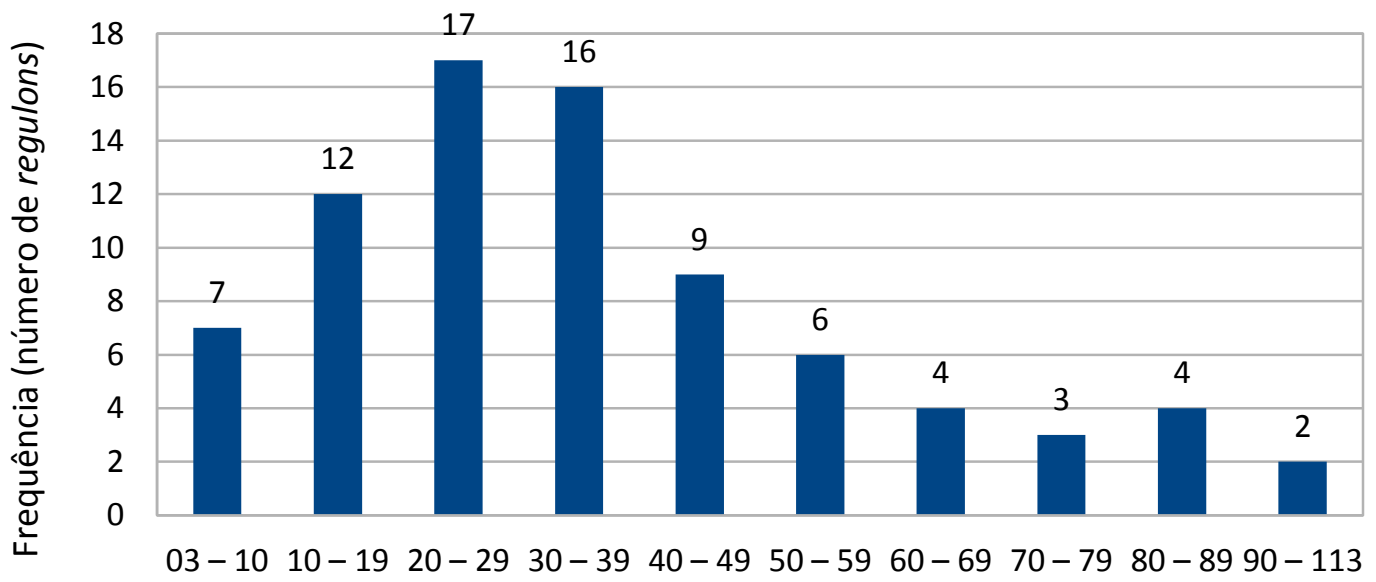

Número de TUs

Figura 16: Distribuição do número de TUs presentes nos regulons preditos. Eixo das abscissas (x): Intervalo (classe) do número de TUs presentes em um mesmo regulon. Eixo das ordenadas (y): Número de regulons que contêm um dado número de TUs.

Distribuição motivos/TU

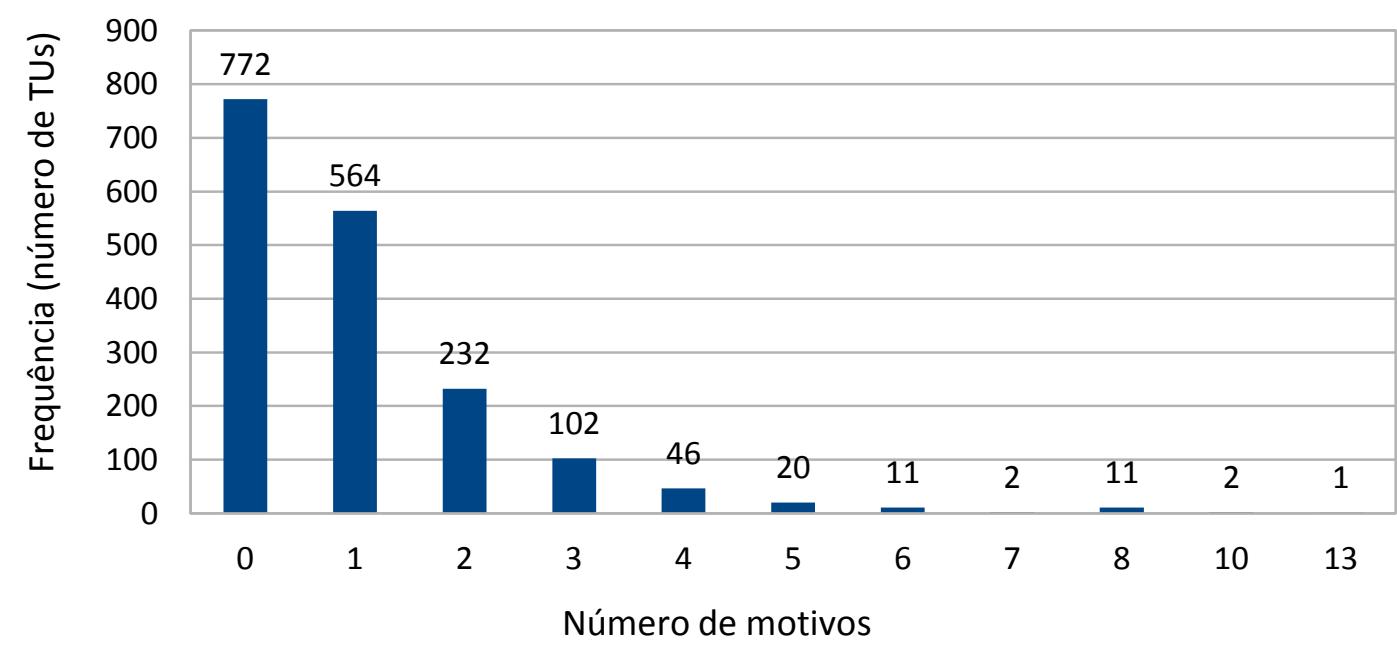

Figura 17: Distribuição do número de motivos que co-ocorrem em uma mesma TU. Eixo das abscissas (x): Número de motivos que co-ocorrem em um mesmo promotor, isto é, número de TFs que putativamente regulam uma mesma TU. Eixo das ordenadas $(y)$ : Número de TUs reguladas por um dado número de TFs.

Ao aplicarmos uma metodologia ab initio para predição de motivos regulatórios em um genoma de interesse nos deparamos com uma restrição inerente à metodologia onde 
diversos motivos são identificados, mas não sabemos a principio os fatores transcricionais responsáveis por reconhecê-los. Apesar de se tratar de um problema ainda sem uma solução computacional universal, a atribuição do par TF/motivo pode ser feita por pelo menos duas estratégias. A primeira, e talvez mais simples, consiste em comparar os novos motivos identificados com motivos previamente caracterizados, ou seja, motivos para os quais já se sabe os TFs reguladores (Wels et al., 2006; Liu et al., 2008; Fadda et al., 2009). A segunda estratégia se baseia na observação de que genes reguladores e genes regulados tendem a estar localizados no cromossomo próximos uns aos outros (Tan et al., 2005) (Fadda et al., 2009). (Tan et al., 2005) observou que em E. coli de fato existe uma restrição na distância entre o gene regulador e o sítio de ligação mais próximo a ele, isto é, pares cognatos de TFs e motivos estão significativamente mais próximos entre si quando comparados a pares não cognatos. Isto significa que perto de um dado TF provavelmente exista um sítio de ligação reconhecido pelo mesmo, uma afirmação que está de acordo com o fato de que os TFs geralmente exercem autorregulação de seus genes (Rodionov, 2007). Em E. coli, por exemplo, constatou-se que $71 \%$ de todos os TFs conhecidos são autorregulados (Zhang et al., 2012).

No presente trabalho aplicamos as duas abordagens mencionadas para arrecadar evidências a respeito de potenciais fatores transcricionais. Na primeira, os motivos preditos foram comparados com os motivos de E. coli, contidos no banco de dados RegulonDB. Na segunda, estimamos a distância mínima entre TFs e motivos que maximizasse a recuperação e precisão da inferência de verdadeiros pares cognatos, utilizando os regulons preditos a partir dos dados de E. coli como conjunto de dados para a calibragem (Tabela 2, tópico 4.1).

O valor máximo, mínimo e a mediana das distâncias mínimas entre verdadeiros pares de TFs e motivos são, respectivamente, 323785, 449 e 82057 pares de bases. O menor valor de distância mínima que rendeu a melhor combinação de precisão e recuperação para as inferências de TFs foi 1600 pares de bases como é possível notar na figura 18 e tabela 5, indicando que este seria o valor ideal para elencar os potenciais TFs cognatos aos motivos preditos pela abordagem ab initio. Desta forma, os pares de TFs e motivos que apresentaram distância mínima menor ou igual 1600 pares de bases foram considerados potenciais pares cognatos. 


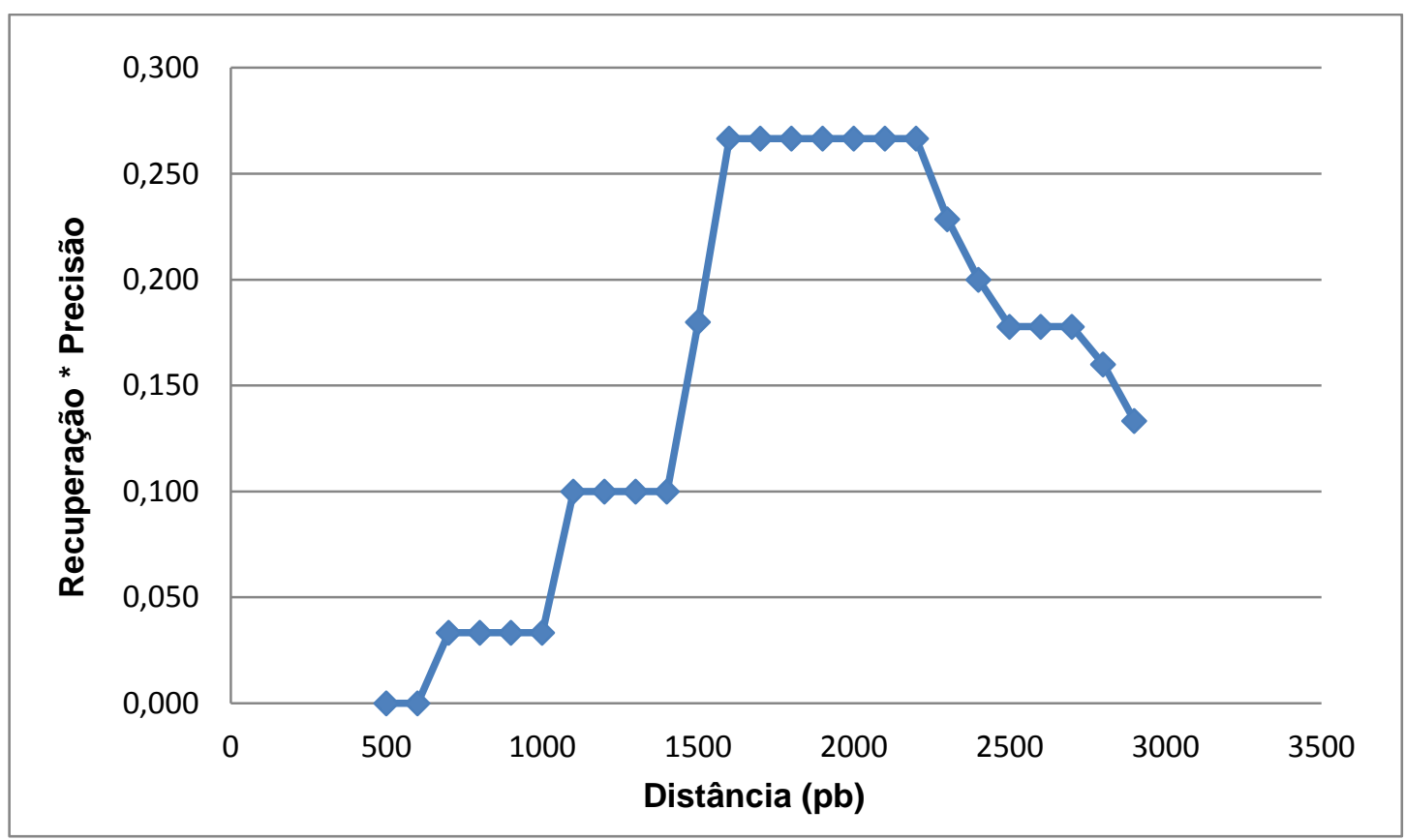

Figura 18: Distâncias mínimas para identificação de verdadeiros pares de TFs e motivos regulatórios. As distâncias mínimas (em pares de bases) entre TFs e seus respectivos motivos foram calculadas, tendo como referência os regulons inferidos a partir dos dados regulatórios de $E$. coli. Da mesma forma, as distâncias mínimas entre TFs e motivos não cognatos foram calculadas. A recuperação vezes a precisão (eixo y) está graficamente representada para diferentes distâncias de corte (eixo x), que foram variadas de 500 a 3000, em janelas de 100 .

Tabela 5: Valores de recuperação e pecisão obtidos com diferentes valores de corte

$\begin{array}{cccc}\begin{array}{c}\text { Corte } \\ \text { (distância) }\end{array} & \text { Recuperação } & \text { Precisão } & \text { Recuperação * } \\ 500 & 0,0000 & 0,000000000 & 0,000 \\ 600 & 0,0000 & 0,000000000 & 0,000 \\ 700 & 0,1000 & 0,333333333 & 0,033 \\ 800 & 0,1000 & 0,333333333 & 0,033 \\ 900 & 0,1000 & 0,333333333 & 0,033 \\ 1000 & 0,1000 & 0,333333333 & 0,033 \\ 1100 & 0,2000 & 0,500000000 & 0,100 \\ 1200 & 0,2000 & 0,500000000 & 0,100 \\ 1300 & 0,2000 & 0,500000000 & 0,100 \\ 1400 & 0,2000 & 0,500000000 & 0,100 \\ 1500 & 0,3000 & 0,600000000 & 0,180 \\ \underline{\mathbf{1 6 0 0}} & \underline{\mathbf{0 , 4 0 0 0}} & \underline{\mathbf{0 , 6 6 6 6 6 6 6 6 7}} & \underline{\mathbf{0 , 2 6 7}} \\ \underline{\mathbf{1 7 0 0}} & \underline{\mathbf{0 , 4 0 0 0}} & \underline{\mathbf{0 , 6 6 6 6 6 6 6 6 7}} & \underline{\mathbf{0 , 2 6 7}}\end{array}$




$\begin{array}{llll}\underline{\mathbf{1 8 0 0}} & \underline{\mathbf{0 , 4 0 0 0}} & \underline{\mathbf{0 , 6 6 6 6 6 6 6 6 7}} & \underline{\mathbf{0 , 2 6 7}} \\ \underline{\mathbf{1 9 0 0}} & \underline{\mathbf{0 , 4 0 0 0}} & \underline{\mathbf{0 , 6 6 6 6 6 6 6 6 7}} & \underline{\mathbf{0 , 2 6 7}} \\ \underline{\mathbf{2 0 0 0}} & \underline{\mathbf{0 , 4 0 0 0}} & \underline{\mathbf{0 , 6 6 6 6 6 6 6 6 7}} & \underline{\mathbf{0 , 2 6 7}} \\ \underline{\mathbf{2 1 0 0}} & \underline{\mathbf{0 , 4 0 0 0}} & \underline{\mathbf{0 , 6 6 6 6 6 6 6 6 7}} & \underline{\mathbf{0 , 2 6 7}} \\ \underline{\mathbf{2 2 0 0}} & \underline{\mathbf{0 , 4 0 0 0}} & \underline{\mathbf{0 , 6 6 6 6 6 6 6 6 7}} & \underline{\mathbf{0 , 2 6 7}} \\ 2300 & 0,4000 & 0,571428571 & 0,229 \\ 2400 & 0,4000 & 0,5000000000 & 0,200 \\ 2500 & 0,4000 & 0,4444444444 & 0,178 \\ 2600 & 0,4000 & 0,444444444 & 0,178 \\ 2700 & 0,4000 & 0,444444444 & 0,178 \\ 2800 & 0,4000 & 0,4000000000 & 0,160 \\ 2900 & 0,4000 & 0,333333333 & 0,133\end{array}$

Para acessar a consistência dos regulons preditos calculamos a correlação de expressão média dos respectivos genes, tendo como base valores de expressão gênica global compilados de 32 experimentos independentes de microarranjos de DNA (da Silva, 2010), e verificamos a existência ou não de categorias funcionais COG super-representadas. Os resultados completos das análises de consistência, os genes presentes nos respectivos regulons, os TFs candidatos e as matrizes Xylella-específicas (arquivos texto individuais cujo formato é compatível com a ferramenta MAST) são apresentados como material suplementar contido em CD-ROM.

Os resultados obtidos com esta abordagem correspondem, dentro do que é de nosso conhecimento até então, ao estudo mais compreensivo visando à identificação de elementos cis-regulatórios em $X$. fastidiosa, os quais aguardam ainda validação experimental. Esperamos que os resultados disponibilizados sirvam de suporte para estudos futuros visando à elucidação de rotas metabólicas, anotação de genes, análises de regulação transcricional, análises de evolução de redes regulatórias e elementos cis-regulatórios, entre outros.

\subsection{Análises comparativas entre cepas de Xylella fastidiosa}

\subsubsection{Promotores críticos}

\subsubsection{Xylella fastidiosa 9a5c - Xylella fastidiosa Temecula1}


Para detectar diferenças significativas entre promotores das cepas 9a5c, um isolado obtido de laranjeira doce (Citrus sinensis) do município de Macaubal no estado de São Paulo (Li et al., 1999), e Temecula1, um isolado virulento de videira obtido na Califórnia (EUA) (Van Sluys et al., 2003), os promotores de TUs com sintenia ou contexto genômico dos promotores conservados foram alinhados. Para cada par de promotores comparados foi gerado um score normalizado pelo comprimento do alinhamento e a frequência absoluta obtida para cada score está representada na figura 19, sendo 5 o máximo score possível após normalização. A média e o desvio-padrão obtidos foram 4.483 e 0.312 , respectivamente, do total de 765 comparações realizadas. 104 pares de promotores (aproximadamente 13,6\%) tiveram score abaixo de um desvio-padrão em relação à média, os quais foram considerados pares de promotores críticos, isto é, com diferenças possivelmente significativas em termos regulatórios. A lista de promotores críticos é apresentada em anexo (anexo 1).

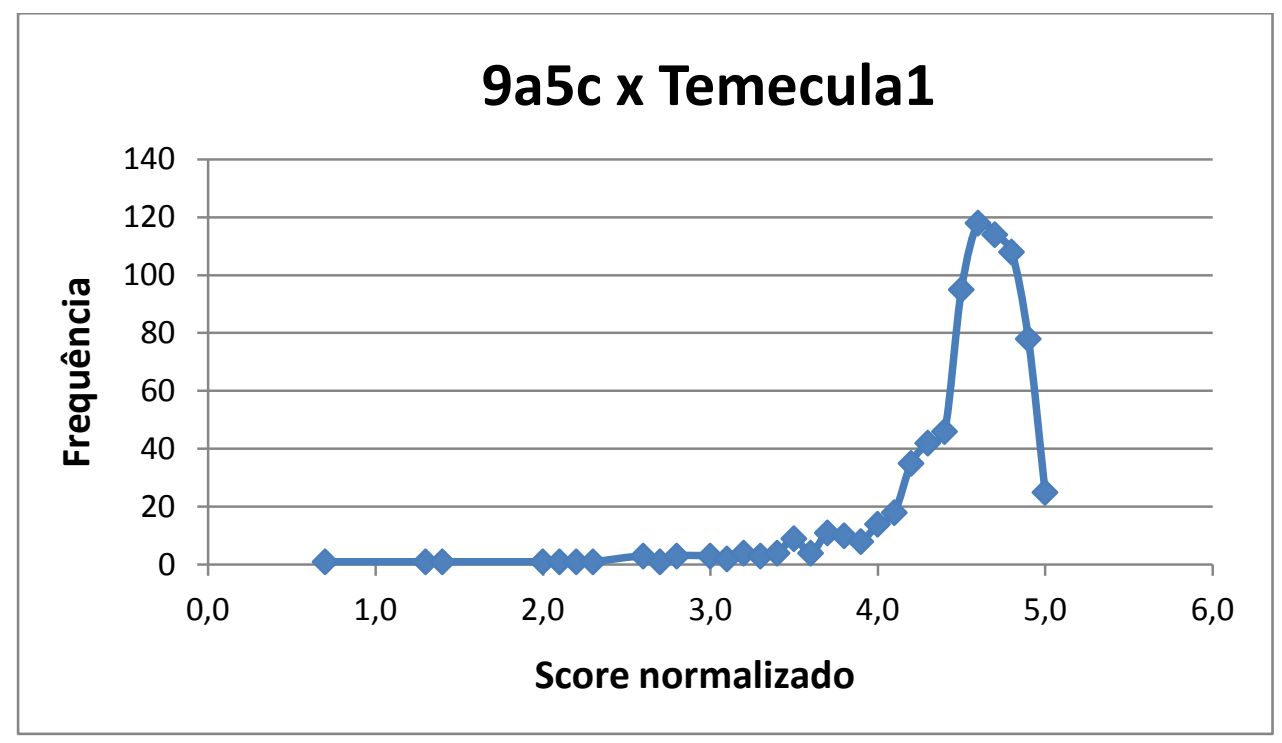

Figura 19: Frequência de scores normalizados na comparação de promotores entre as cepas 9a5c e Temecula1.

Apenas 17 dos 104 pares de promotores considerados críticos, aproximadamente $16.3 \%$, contêm em pelo menos uma das TUs correspondentes um ou mais genes sem evidência sobre suas funções. Em parte isto se deve ao critério conservador da metodologia empregada, que compara apenas pares de promotores cujas TUs apresentam contexto do promotor ou sintenia conservada. Mesmo assim trata-se de uma constatação interessante já que aproximadamente $31 \%$ dos genes de $9 a 5 c$ e $32 \%$ em Temecula1 não apresentam funções definidas (dados obtidos diretamente da plataforma IMG-ER do DOE JGI).

O resultado desta análise inclui genes envolvidos em funções celulares básicas (anexo 1) tais como genes codificadores de proteínas ribossomais, relacionadas à síntese e modificação de RNAs transportadores, envolvidas em vias respiratórias, transcrição e 
replicação. Não descartamos a hipótese de eventuais discrepâncias na determinação dos sítios de início de tradução dos genes terem contribuído para resultados espúrios, mesmo que ambos os genomas tenham sido submetidos ao mesmo pipeline de anotação. No entanto, diante desta eventual possibilidade, o algoritmo de alinhamento local utilizado para as comparações deve ser suficiente para contornar o problema na maioria dos casos, pois aborta a extensão do alinhamento nas extremidades das sequências caso esta se torne custosa demais (i.e., resulte em demasiada penalização para o score do alinhamento). Portanto, as diferenças capturadas nesta análise estão em sua maioria relacionadas ao interior das sequências promotoras e não a suas extremidades $3^{\prime}$ e $5^{\prime}$.

Interessantemente, genes outrora identificados como altamente divergentes entre 9a5c e Temecula1, cujas sequências de aminoácidos apresentam de $20 \%$ a $80 \%$ de identidade, desempenham funções correspondentes aos genes com promotores críticos como é o caso daqueles envolvidos em sistemas de restrição (exonuclease e endonuclease), codificadores de toxinas (lisozimas) e relacionados à motilidade e adesão (adesinas) (Van Sluys et al., 2003). Porém, o que mais chama a atenção de nossa lista é o claro enriquecimento com genes codificadores de proteínas relacionadas ao transporte de carbohidratos, cofatores, drogas e aminoácidos; envolvidas na seletividade de íons ou moléculas; componentes de sistemas de secreção (geral e do tipo IV) e envolvidas na síntese da parede celular. As funções dessas estruturas, em conjunto, permitem o fluxo adequado da informação que parte do meio externo e é transmitida ao interior celular para que haja uma resposta adequada do sistema biológico. Na prática propiciam a secreção de efetores tais como enzimas responsáveis pela degradação de nutrientes e toxinas que contribuem para a competição e sobrevivência celular; permitem o intercâmbio de moléculas responsáveis pela captura de cofatores; são responsáveis pela aquisição de nutrientes e moléculas sinalizadoras; e funcionam como barreira para substâncias prejudiciais (Koebnik et al., 2000; Camilli e Bassler, 2006; Tseng et al., 2009).

Nossos resultados sugerem que genes envolvidos na comunicação com o meio externo estão sob diferentes mecanismos de controle transcricional nestas duas cepas e, portanto, devem responder diferencialmente a estímulos ambientais. Genes codificadores de enzimas envolvidas na síntese de moléculas sinalizadoras, reguladores transcricionais e proteínas sensores de sistemas de dois componentes também estão presentes na lista e reforçam a hipótese de que a modulação diferencial da expressão de genes responsáveis por "sentir", "transmitir" e "responder" a estímulos deve contribuir para características ecológicas e fenotípicas particulares de cada cepa, talvez até mesmo para a natureza mais agressiva de Temecula1 em relação à 9a5c (Almeida et al., 2001). Essas diferenças são provavelmente uma consequência de milhares de anos de adaptação a hospedeiros vegetais específicos.

Para verificar se as diferenças detectadas podem de fato corresponder a potenciais elementos cis-regulatórios os pares de promotores críticos foram inspecionados a procura de instâncias semelhantes a cada um dos 10 motivos inferidos a partir das informações regulatórias de $E$. coli. Os resultados discrepantes obtidos foram manualmente curados e aqueles considerados relevantes estão destacados em negrito em anexo 1 e serão discutidos a seguir. 
Um motivo para Fis foi identificado no promotor de um gene codificador para uma succinyl-diaminopimelate desuccinylase em Temecula1 e se mostrou ausente no promotor do ortólogo em 9a5c. A instância de Fis se situa em uma região do promotor comum a somente três cepas de $X$. fastidiosa, dentre as 12 utilizadas no presente estudo (ver metodologia), todas obtidas na América do Norte : M23, isolada de amendoeira(Chen et al., 2010); GB514, isolada de videira (Schreiber, 2010); e Temecula1, também isolada de videira. Este segmento único às três cepas estende-se da região -106 até -36 em relação ao sítio de início de tradução dos respectivos genes. O segmento, junto com a instância de Fis, está completamente conservado nas três cepas que o contém (figura 20) e apresenta baixo conteúdo GC, apenas 32\%. A região gênica em Temecula1 (promotor + região codificante) apresenta $54 \%$ de conteúdo GC, a região promotora $44 \%$ e $48 \%$, com e sem o segmento extra respectivamente. Uma busca no genoma de 9a5c (BLAST) não detectou qualquer correspondência a este segmento extra de Temecula1. Estas observações em conjunto sugerem enfaticamente uma origem xenóloga, em decorrência de um evento recente de transferência lateral. Se comprovada a funcionalidade deste sítio putativo de Fis, este seria um possível exemplo de ganho de elemento cis-regulatório mediado por transferência lateral, um fenômeno ainda não registrado em bactérias para nosso conhecimento.

A enzima succinyl-diaminopimelate desuccinylase é responsável pela síntese de lisina e D,L-diaminopimelic acid (meso-DAP), ambos constituintes da camada de peptideoglicano presente na parede celular bacteriana (Born e Blanchard, 1999). Portanto, a regulação diferenciada deste gene pode estar relacionada a diferenças fenotípicas. Em Salmonella enterica notou-se que Fis é responsável pela modulação de genes envolvidos na síntese de aminoácidos, ácidos graxos e, inclusive, de genes localizados em ilhas de patogenicidade (Kelly et al., 2004).

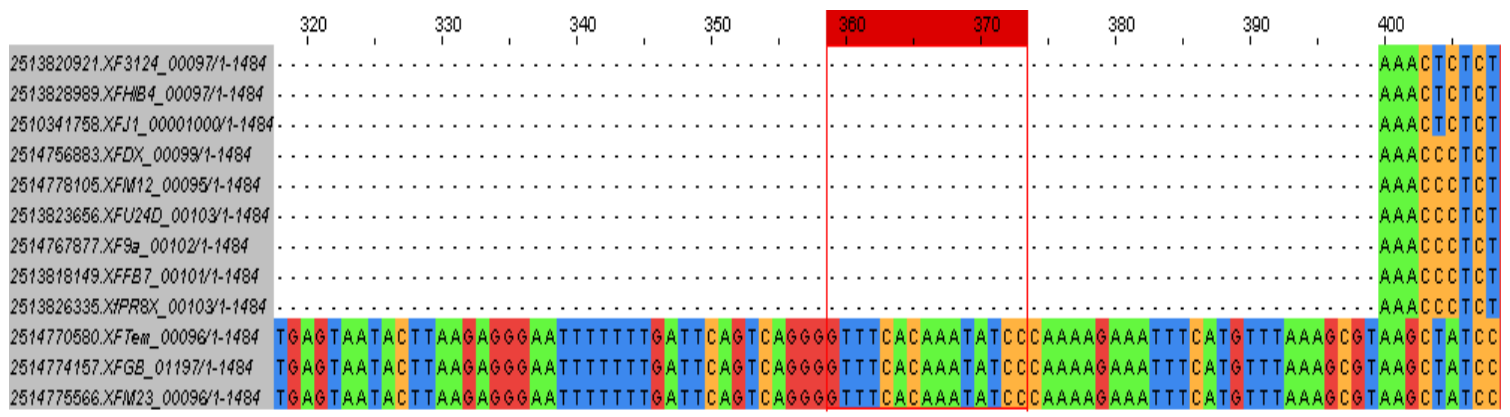

Figura 20: Alinhamento da porção genômica referente ao promotor do gene codificador de succinyl-diaminopimelate desuccinylase. Figura extraída da plataforma IMG-ER do DOE JGI, utilizada para anotação dos genomas. Sítio de Fis está destacado em vermelho, comum a três cepas de X. fastidiosa: Temecula1 (décima linha), M23 (décima segunda linha) e GB514 (décima primeira linha).

Ainda em relação à Fis, uma instância identificada em Temecula1 no promotor da TU que contém os genes de acetyl-CoA carboxylase e fosfoglucosamine mutase, enzimas 
também envolvidas na síntese de peptideoglicano (Jolly et al., 1999), se mostrou ausente em 9a5c. O hit se localiza em um segmento ausente em 5 cepas sul americanas: U24d, Fb7 e 9a5c isolados de citros, $\operatorname{Pr} 8 x$ isolado de ameixeira e 3124 isolado de café. O segmento adicional extende-se da porção -285 a -317 em relação ao sítio de início de tradução do gene acetyl-coA-carboxylase em Temecula1 (figura 21) e apresenta conteúdo GC de 42\%. A região gênica (promotor + região codificante) apresenta $52 \%$ de conteúdo GC, a região promotora $49 \%$ e $50 \%$, com e sem o segmento adicional respectivamente.

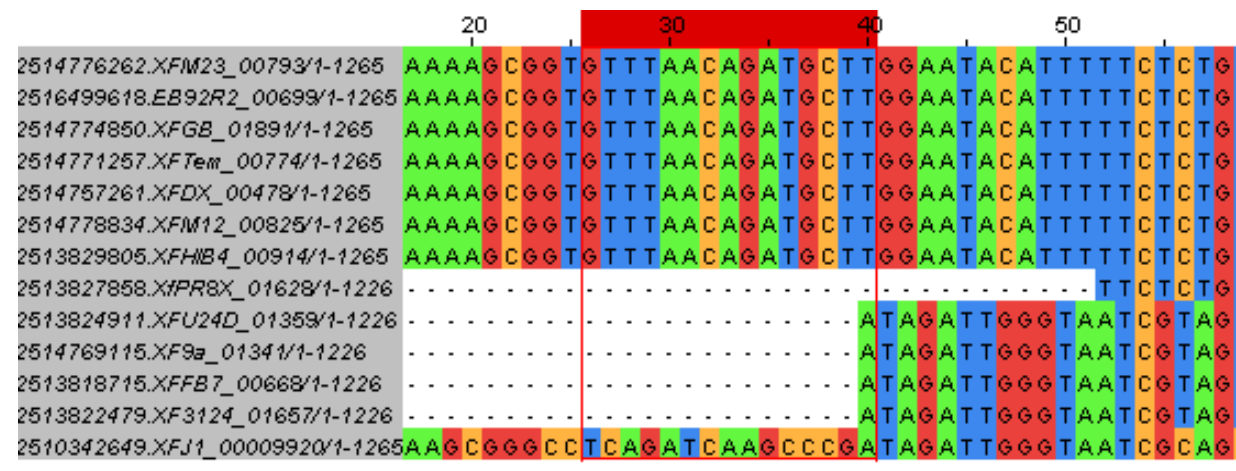

Figura 21: Alinhamento da porção genômica referente ao promotor da TU que contém uma acetyl-CoA carboxylase e fosfoglucosamine mutase. Figura extraída da plataforma IMG-ER do DOE JGI, utilizada para anotação dos genomas. Região correspondente ao sítio de Fis identificado em Temecula1 (quarta linha) está destacada em vermelho e se encontra corrompido nas cepas 9a5c, U24d, 3124, Pr8x e Fb7 (décima, nona, décima segunda, oitava, décima primeira linha, respectivamente).

Foi constatado um sítio de Fur em Temecula1 na região promotora de um operon conservado contendo uma proteína da superfamília das fosfatases ácidas e uma hidrolase metal dependente associada à membrana (figura 22). Esta instância de Fur está ausente em todas as cepas sul americanas em decorrência de um inserto extra de 9 pares de base que mapeia no interior do sítio de Fur nas cepas norte americanas. Porém, como se trata de uma região homopolimérica essas diferenças podem ser reflexos de artefatos de sequenciamento (Huse et al., 2007).

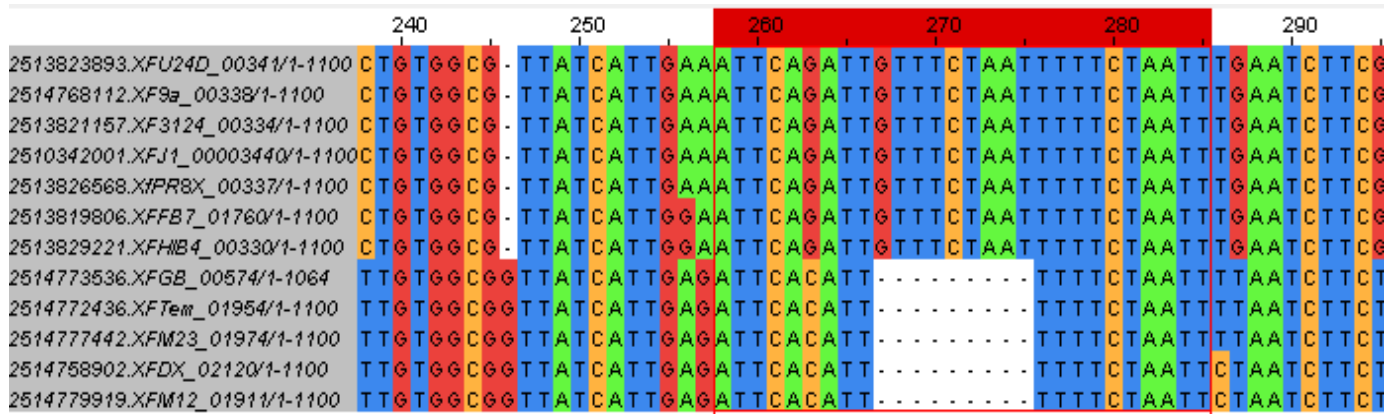

Figura 22: Alinhamento da porção genômica referente ao promotor da TU que contém uma proteína da superfamília das fosfatases ácidas e uma hidrolase metal dependente associada à membrana. Figura extraída da plataforma IMG-ER do DOE JGI, utilizada para anotação dos genomas. Região correspondente ao sítio de Fur identificado em Temecula1 (nona linha) está destacada em vermelho e se encontra corrompido em 9a5c (segunda linha). 
Por fim, sítios de CRP presentes nos promotores dos genes codificadores para uma proteína de membrana relacionada ao transporte de ferro e uma multi-cobre oxidase foram detectados em 9a5c, mas não o foram em Temecula1.

As possíveis diferenças cis-regulatórias constatadas são, em sua maioria, relacionadas a enzimas responsáveis pela síntese de componentes de parede celular ou proteínas de membrana e, portanto, reforçam nossa hipótese de modulação diferencial de genes relacionados à comunicação com o meio externo, o que deve contribuir para as particularidades fenotípicas e ecológicas de cada uma.

\subsubsection{Xylella fastidiosa 9a5c - Xylella fastidiosa J1a12}

Para detectar diferenças significativas entre promotores das cepas 9a5c e J1a12, um isolado não virulento de Citrus sinensis (Monteiro et al., 2001; Koide et al., 2004), alinhamos os promotores de TUs com sintenia ou contexto genômico dos promotores conservados. Para cada par de promotores comparados foi gerado um score normalizado pelo comprimento do alinhamento e a frequência absoluta obtida para cada score está representada na figura 23, sendo 5 o máximo score possível após normalização. A média e o desvio-padrão obtidos foram 4.935 e 0.105 , respectivamente, do total de 964 comparações realizadas. 98 pares de promotores, aproximadamente $10 \%$, tiveram score abaixo de um desvio-padrão em relação à média, os quais foram considerados pares de promotores críticos, isto é, com diferenças significativas. A lista de promotores críticos é apresentada em anexo 2.

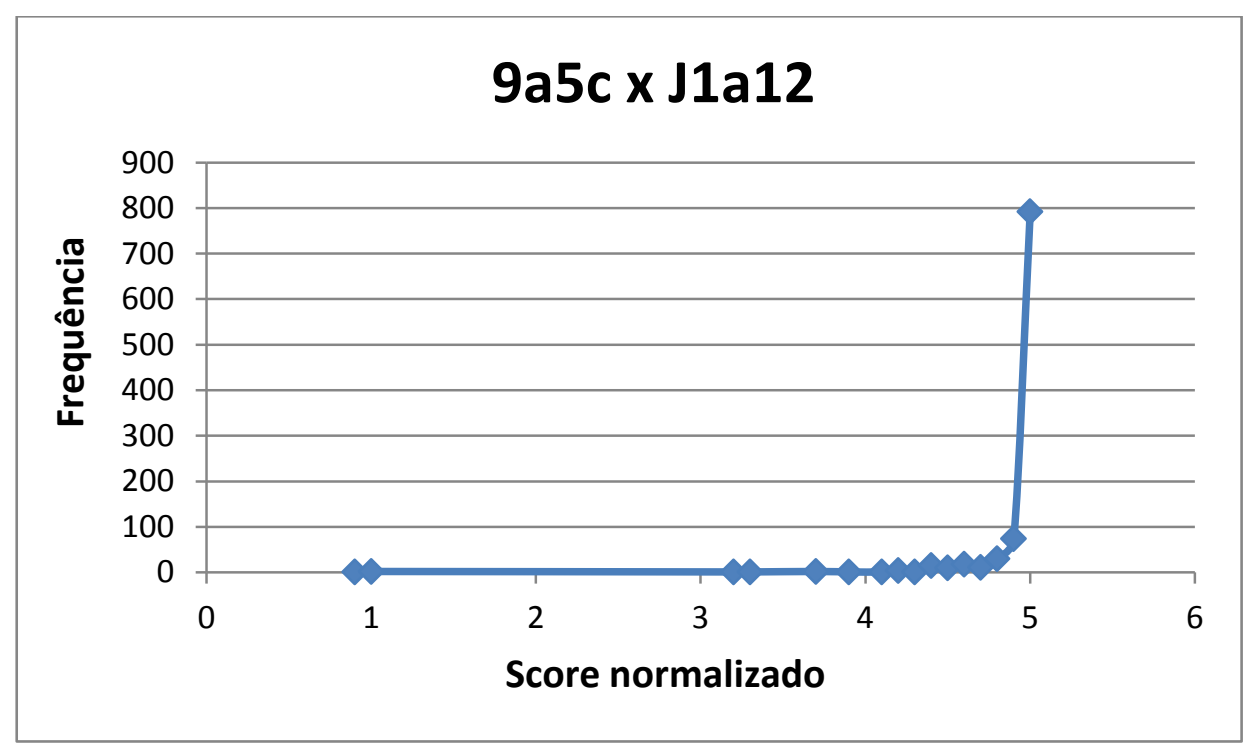

Figura 23: Frequência de scores normalizados na comparação de promotores entre as cepas 9a5c e J1a12. 
Nota-se que a proporção de promotores com score máximo para este par de cepas é muito maior do que o obtido para o par 9a5c e Temecula1, 83\% e 3\% respectivamente. Esta tendência já era esperada, já que a análise filogenética destas cepas sugere uma relação mais próxima entre 9a5c e J1a12 (Pierry, 2012).

Diferentemente da comparação com Temecula1, a lista de promotores críticos de $9 a 5 c$ e J1a12 apresenta diversas TUs cujos genes estão relacionados a pró-fagos, o que deve ter contribuído para um aumento na proporção de TUs com ao menos um gene sem evidência sobre sua função $(24.5 \%)$. As funções dos genes presentes na lista de promotores críticos condizem com as funções dos genes divergentes, vislumbrados no trabalho de Mestrado responsável pelo sequenciamento do genoma da cepa J1a12 (Pierry, 2012). Entre eles destacam-se genes envolvidos na biogênese do pilus do tipo IV, na recombinação de DNA, na produção de toxinas e componentes do sistema de restrição do tipo I. Contudo, o que mais chama nossa atenção é quantidade de genes cujas funções remetem a divisão celular, reparo de DNA e regulação transcricional (TFs), o que pode significar que a replicação celular em 9a5c e J1a12 responda diferencialmente a estímulos externos tornando-as significativamente diferentes em termos fisiológicos.

Diferenças relacionadas a elementos cis-regulatórios foram constatadas, entre elas um sítio de Fur identificado no promotor de uma bacteriocina em J1a12, mas ausente no promotor do ortólogo em $9 \mathrm{a} 5 \mathrm{c}$ devido a 5 polimorfismos na região correspondente ao sítio (figura 24). Em 9a5c, o gene codificador da bacteriocina (lócus XF1693 na anotação original) foi super-expresso em baixa concentração de ferro, mas não foi diferencialmente expresso em excesso de ferro (Zaini et al., 2008) como seria esperado de uma regulação canônica por Fur. Esta observação suporta a hipótese da ausência do sítio de Fur no promotor do gene em $9 a 5 c$.

Um estudo com Salmonella typhimurium aponta a contribuição do ganho de elemento cis-regulatório para sua adaptação patogênica no hospedeiro animal (Osborne et al., 2009). Talvez a ausência do sítio ou a baixa afinidade de Fur pelo promotor bacteriocina permita a expressão quasi-constitutiva de seu produto gênico e contribua para a natureza virulenta de $9 a 5 c$, uma vez que a ação das bacteriocinas está diretamente relacionada à competição e sobrevivência celular (Riley e Wertz, 2002).

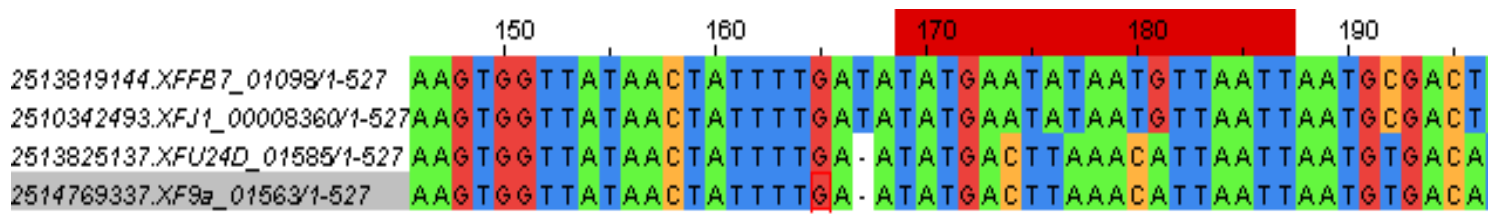

Figura 24: Alinhamento da porção genômica referente ao promotor do gene codificador de uma bacteriocina Figura extraída da plataforma IMG-ER do DOE JGI, utilizada para anotação dos genomas. Região correspondente ao sítio de Fur identificado em J1a12 (segunda linha) está destacada em vermelho e se encontra corrompido em 9a5c (quarta linha). 
Outra diferença foi constatada em um repressor transcricional relacionado a bacteriófagos, que apresenta um sítio de CRP e um sítio de Fur nos promotores de duas das três cópias presentes no cromossomo de J1a12 e nenhum sítio, tanto de Fur como de CRP, nos promotores das duas cópias presentes em 9a5c. A figura 25 mostra o alinhamento entre o promotor de umas das cópias de J1a12 com o promotor do gene correspondente em 9a5c e destaca o sítio de CRP em vermelho. A figura 26 mostra o mesmo alinhamento, mas com o sítio de Fur destacado. É interessante notar que os sítios de Fur e CRP estão parcialmente sobrepostos no promotor de J1a12.

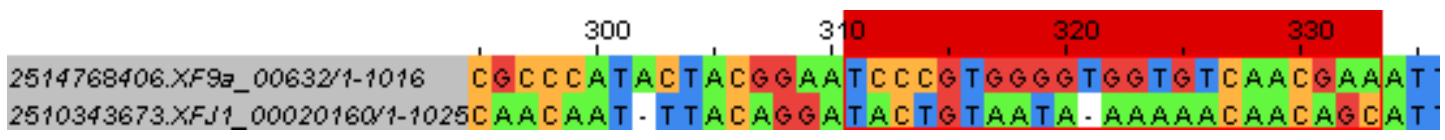

Figura 25: Alinhamento da porção genômica referente ao promotor do gene codificador de um repressor transcricional relacionado à bacteriófago. Figura extraída da plataforma IMG-ER do DOE JGI, utilizada para anotação dos genomas. Região correspondente ao sítio de CRP identificado em J1a12 (segunda linha) está destacada em vermelho e se encontra corrompido em 9a5c (primeira linha).

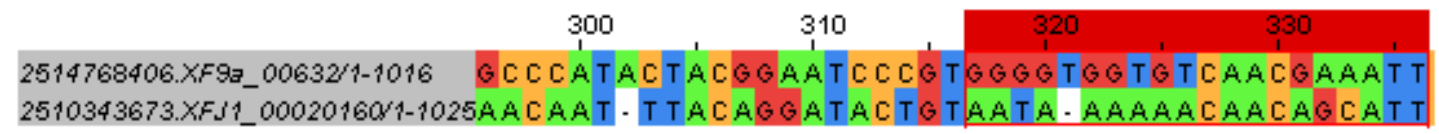

Figura 26: Alinhamento da porção genômica referente ao promotor do gene codificador de um repressor transcricional relacionado à bacteriófago. Figura extraída da plataforma IMG-ER do DOE JGI, utilizada para anotação dos genomas. Região correspondente ao sítio de Fur identificado em J1a12 (segunda linha) está destacada em vermelho e se encontra corrompido em 9a5c (primeira linha).

Uma busca realizada contra proteínas de E. coli, contidas no banco de dados do NCBI, constatou que a sequência de aminoácidos do repressor transcricional relacionado a bacteriófagos de J1a12 (XFJ1_00020160) apresenta 34\% de identidade, 95\% de cobertura (query coverage) e e-valor na ordem de $10^{-30}$ com a sequência do gene putativo a cI presente em E. coli ED1a (Touchon et al., 2009). Esse valor relativamente baixo de identidade deve ser interpretado com cautela, já que genes de pró-fagos tendem a estar submetidos a altas taxas de mutação (Canchaya et al., 2003; Casjens, 2003). Dentre todas as sequências proteicas de E. coli ED1a, a sequência de cI é a que mais se assemelha a XFJ1_00020160 e vice-versa (melhor BLAST bidirecional). Portanto, XFJ1_00020160 e cI foram considerados ortólogos putativos.

A proteína cI de E. coli, codificada dentro de uma região de pró-fago e que contém em sua composição motivos de peptidase e hélice-volta-hélice, é conhecida por reprimir 
genes estruturais do bacteriófago do tipo lambda, que permanece em estado de dormência dentro do hospedeiro enquanto cI é expresso (ciclo lisogênico). No entanto, assim que esse repressor transcricional para de atuar os genes estruturais do bacteriófago são ativados ocorrendo a mudança do ciclo lisogênico para o ciclo lítico no qual a célula hospedeira é rompida por partículas virais, fenômeno conhecido como lise celular (Herskowitz, 1973). Um estudo conduzido com $E$. coli comprovou que a proteína cI é também responsável pela repressão do gene bacteriano $p c k A$, que auxilia no crescimento celular em ausência de glicose. Células de $E$. coli contendo o gene cI cresciam normalmente em meio rico em glicose, porém apresentavam crescimento lento em meio sem glicose suplementado com fontes alternativas de carbono, quando comparado ao crescimento de células sem o mesmo gene (Chen et al., 2005).

Em J1a12 as sequências de aminoácidos de dois dos genes putativamente ortólogos a cI são 100\% idênticos entre si (os que contêm os sítios de CRP e Fur), os quais apresentam um motivo hélice-volta-hélice (típico em TFs), responsável pela ligação a moléculas de DNA, e um motivo de peptidase. Já a terceira cópia, que contém apenas o motivo de peptidase, apresenta $56 \%$ de identidade com qualquer um dos dois outros genes. Em 9a5c, as sequências de aminoácido das duas cópias apresentam 44\% de identidade entre si, sendo que uma delas contém tanto o motivo hélice-volta-hélice como o motivo de peptidase, enquanto a outra contém apenas o motivo de peptidase.

Não é possível ter certeza, a princípio, se a ausência dos motivos hélice-volta-hélice tornam esses TFs inativos e tampouco sabemos se os sítios de CRP e Fur são de fato funcionais em J1a12. Contudo, é plausível que as diferenças apontadas possam estar relacionadas a particularidades fisiológicas de cada cepa como, por exemplo, a taxa diferenciada de crescimento em fontes de carbono distintas, seja pelo número de cópias ativas do repressor, que pode ser responsável pela modulação de genes do metabolismo bacteriano (como ocorre em $E$. coli), seja pelo estímulo ambiental a que respondem esses reguladores devido à presença dos sítios de CRP e Fur em J1a12. Além da proteína cI em $E$. coli, a proteína RepR em Clostridium difficile, um repressor putativo de genes do bacteriófago $\Phi C D 119$, mostrou-se responsável pela repressão de genes bacterianos relacionados a patogenicidade e foi postulado que o mesmo pode ter papel na modulação dos genes codificadores das toxinas $A$ e $B$, fundamentais para a agressividade deste patógeno (Govind et al., 2009). Adicionalmente, linhagens de Vibrio harveyi e Listonella pelagia infectadas por bacteriófagos lisogênicos mostraram alteração fenotípicas relacionadas à assimilação diferencial de substratos em relação a linhagens não infectadas (Vidgen et al., 2006; Paul, 2008). Estes estudos reforçam nossa hipótese de que a atuação de repressores de bacteriófagos em $X$. fastidiosa podem de fato contribuir para as particularidades fenotípicas de 9a5c, J1a12 e até mesmo outras cepas. Em Temecula1, por exemplo, a única cópia putativa de cI não contém o motivo hélice-volta-hélice em sua sequência o que sugere que seu produto não seja ativo como regulador transcricional de genes desta cepa, conhecida por causar sintomas no hospedeiro vegetal considerados mais agressivos que aqueles causados por 9a5c (Almeida et al., 2001). Uma lista da distribuição de cópias putativas de cI nos cromossomos de diferentes cepas de $X$. fastidiosa é apresentado em anexo 3. 
Os genes putativamente correspondentes a cI em 9a5c, loci XF0696 e XF1658 na anotação original, não apresentaram expressão diferencial em experimentos de microarranjo realizados em diferentes concentrações de glicose, como poderíamos esperar caso fossem regulados por CRP (da Silva, 2010). Em carência de ferro XF1658 foi super-expresso, mas não foi modulado em excesso de ferro (Zaini et al., 2008) como ocorre na regulação tradicional por Fur (repressão em presença de ferro). Estas observações em conjunto suportam a ausência de sítios de CRP e Fur nos promotores dos genes em 9a5c. O comportamento transcricional desses genes em J1a12 é ainda uma incógnita e, devido às possíveis implicações na fisiologia celular, merecem investigação experimental.

Por fim, ressaltamos que a ausência de outras discrepâncias consideradas relevantes não necessariamente significa que os mecanismos de regulação transcricional nestas cepas estejam altamente conservados. Esta constatação, porém, tange à dificuldade de se estabelecer critérios objetivos para identificação in silico de diferenças significativas em elementos cis-regulatórios, isto é, que provavelmente resultam em diferenças no balanço transcricional, quando se trata de dois genomas tão semelhantes como neste caso. Um complicador adicional é a falta de conhecimento (se é que existente) de um vocabulário ou código universal subjacente às interações entre TFs e TFBSs, como aquele disponível para a correspondência entre transcritos de RNA e proteínas. Em uma situação ideal este código deveria levar em consideração não apenas a composição de elementos cis-regulatórios, mas também fatores epigenéticos como, por exemplo, o padrão de metilação do DNA nas regiões promotoras; a compactação do cromossomo e torções mediadas por proteínas específicas (nucleoid-associated proteins); e a cooperação sinergica entre módulos de TFs e a RNA polimerase (Browning e Busby, 2004; Casadesus e Low, 2006; van Hijum et al., 2009; Browning et al., 2010; Dillon e Dorman, 2010).

\subsubsection{Distribuição de motivos regulatórios em diferentes genomas de Xylella fastidiosa - matrizes cepa-específicas}

Os 829 motivos preditos pela estratégia de phylogenetic footprinting (ab initio) foram utilizados para varrer as sequências promotoras de 12 cepas de $X$. fastidiosa, para as quais as sequências genômicas estavam adequadamente disponíveis. Para cada cepa, foram geradas matrizes cepa-específicas correspondentes aos motivos que apresentaram 4 instâncias (hits) ou mais no genoma. Motivos com menos de 4 instâncias em um dado genoma foram considerados ausentes. Os números de motivos totais, exclusivos e regiãoexclusivos, isto é, motivos presentes somente em cepas isoladas na mesma região geográfica do globo terrestre (hemisfério norte ou sul), foram computados para cada uma das 12 cepas. Os valores obtidos são apresentados na tabela 6 . 
Tabela 6: Distribuição de motivos nos genomas de 12 cepas de $X$. fastidiosa.

\begin{tabular}{|c|c|c|c|c|}
\hline Cepas & $\begin{array}{c}\text { Número de } \\
\text { motivos } \\
\text { exclusivo }\end{array}$ & $\begin{array}{c}\text { Número de } \\
\text { motivos } \\
\text { região-exclusivo }\end{array}$ & $\begin{array}{c}\text { Número } \\
\text { total de } \\
\text { motivos }\end{array}$ & $\begin{array}{c}\text { Região de } \\
\text { isolamento } \\
\text { (norte ou sul) }\end{array}$ \\
\hline M23 & 1 & 0 & 42 & Norte \\
\hline Fb7 & 5 & 27 & 70 & Sul \\
\hline Hib4 & 6 & 17 & 62 & Sul \\
\hline GB514 & 0 & 0 & 42 & Norte \\
\hline U24d & 0 & 20 & 80 & Sul \\
\hline Dixon & 5 & 0 & 40 & Norte \\
\hline M12 & 1 & 0 & 37 & Norte \\
\hline 3124 & 2 & 23 & 61 & Sul \\
\hline J1a12 & 6 & 21 & 63 & Sul \\
\hline Temecula1 & 0 & 0 & 41 & Norte \\
\hline Pr8x & 1 & 21 & 60 & Sul \\
\hline 9a5c & 0 & 20 & 80 & Sul \\
\hline
\end{tabular}

Nota-se que o número de motivos tende a ser maior em cepas isoladas no hemisfério sul em relação ao número de motivos das cepas isoladas no norte (tabela 6 e figura 27). Isto provavelmente ocorre porque são as cepas do sul as mais próximas em termos evolutivos à cepa 9a5c (Pierry, 2012), cujo genoma foi utilizado como referência para predição dos motivos. Os números totais de motivos exclusivos e região-exclusivos são 20 e 54 para cepas do sul e 7 e 16 para cepas do norte, respectivamente.

Um teste ANOVA foi realizado para avaliar se as distribuições de motivos entre cepas do norte e cepas do sul são estatisticamente diferentes a $1 \%$ de significância $(p<0.01)$. Com o resultado obtido $\left(p=8 \times 10^{-06}\right)$ rejeitamos a hipótese de nulidade e concluímos que a diferença na distribuição de motivos entre as amostras (norte e sul) é significativa. Um teste de Levene também foi realizado, a $1 \%$ de significância estatística $(p<0.01)$, para avaliar se as variâncias das amostras (norte e sul) são homogêneas, uma premissa do teste ANOVA. Com o resultado obtido ( $p=0.2231)$ não rejeitamos a hipótese de nulidade, ou seja, as variâncias das amostras não apresentam diferenças significativas sendo, portanto, homogêneas.

O número de motivos comuns a todas as cepas do hemisfério norte e o número de motivos comuns a todas as cepas do hemisfério sul são, respectivamente, 21 e 39 . 0 número de motivos comuns às 12 cepas é 21 . 


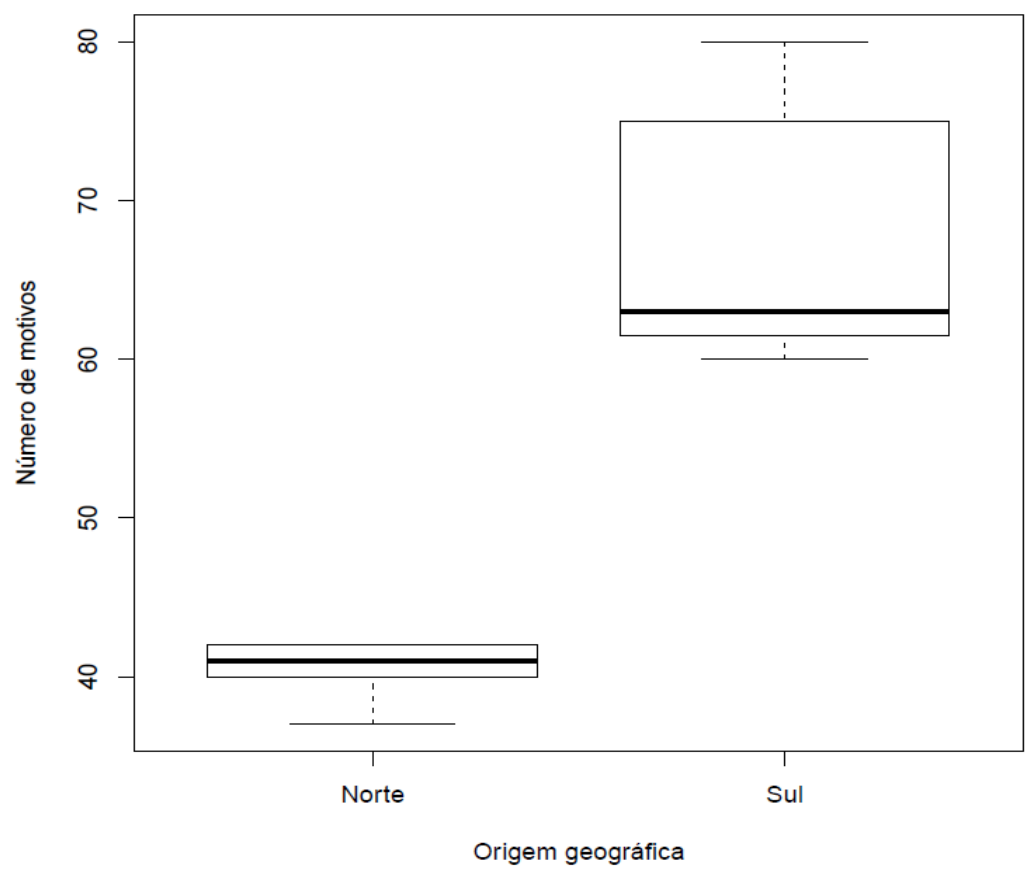

Figura 27: Boxplot da distribuição de motivos totais identificados nas cepas de origens geográficas distintas (norte e sul).

\subsubsection{Análises filogenéticas baseadas em motivos regulatórios}

As matrizes cepa-específicas identificados na etapa anterior foram utilizadas para análises filogenéticas das 12 cepas de $X$. fastidiosa, utilizando-se o genoma de Xanthomonas albilineans GPE PC73 como grupo externo. Nossos objetivos com essas análises são: acessar a variabilidade de motivos cis-regulatórios em $X$. fastidiosa e, portanto, a plasticidade da rede regulatória transcricional subjacente à espécie assim como apresentar uma abordagem alternativa para inferência de sua história evolutiva.

As análises foram realizadas em três contextos distintos. No primeiro contexto, a similaridade entre genomas é calculada a partir da proporção de motivos compartilhados (padrão de presença e ausência), ou seja, pares de genomas que compartilham uma grande proporção de motivos são considerados altamente similares e são agrupados em proximidade na árvore. Um motivo é considerado presente se apresentar no mínimo 4 instâncias em um dado genoma e ausente caso contrário. Esta abordagem acessa especialmente a evolução de regulons locais, isto é, que afetam um pequeno número de TUs, pois captura eventos de expansão e retração do número de TUs contidas em regulons próximos do limiar de corte. Apesar de não ter sido contemplado no presente trabalho, a variação do critério de corte (número mínimo de instâncias) proporcionaria o estudo da evolução dos regulons em diferentes perspectivas. No segundo contexto, levamos em consideração apenas os 15 motivos comuns a $X$. albilineans e todas as 12 cepas de $X$. fastidiosa. Neste caso a similaridade entre pares de genomas reflete a similaridade entre 
motivos correspondentes e, portanto, pares de genomas que apresentam uma grande proporção de motivos altamente similares são agrupados em proximidade na árvore. Esta abordagem tem como objetivo acessar o grau de conservação das sequências de motivos correspondentes, comuns aos 13 genomas. No terceiro contexto, mesclamos o padrão de presença e ausência com os valores de similaridade entre motivos correspondentes para inferência da árvore. Neste caso, tanto a proporção de motivos compartilhados como a proporção de motivos correspondentes altamente similares contribuem para o agrupamento de pares de genomas.

A árvore obtida com o padrão de presença e ausência de motivos apresenta dois grupos bem definidos que separam as cepas de origens geográficas distintas (norte e sul), como mostra a figura 28 , um resultado já esperado tendo em vista a diferença significativa na distribuição de motivos em cepas destes dois grupos (teste ANOVA). A maioria dos nós da árvore, 7 de 11 , apresenta $70 \%$ ou mais de suporte de bootstrap sendo os nós internos aqueles com menores valores, ou seja, com alto grau de indefinição. A separação de cepas de $X$. fastidiosa de acordo com a origem geográfica de isolamento já foi observada em outras análises (Schuenzel et al., 2005; Montero-Astua et al., 2007). Adicionalmente, a falta de suporte em nós internos em inferências filogenéticas desta espécie é recorrente e apresentase como um obstáculo para a definição da história evolutiva (diversificação) de cepas altamente relacionadas (Mehta et al., 2001; Mehta e Rosato, 2001; Qin et al., 2001). O decaimento dos valores de bootstrap em nós internos indica que a presença e ausência de motivos regulatórios não segue um padrão bem definido entre cepas mais aparentadas, principalmente nas cepas sul americanas como fica evidente no clado da figura 28 que contém: Pr8x, 3124, Fb7, J1a12, 9a5c e U24d. Acreditamos que os baixos valores de bootstrap em alguns nós seja decorrente das taxas diferenciadas de recombinação existente entre cepas (Almeida et al., 2008; Nunney et al., 2013), provavelmente favorecidas pela interação preferencial com hospedeiros vegetais específicos. A ocorrência de uma série de mutações independentes nos genomas deve também contribuir para o fenômeno observado, mas parece improvável que seja suficiente para explicá-lo.

Estudos de infeç̧ão cruzada suportam a hipótese de especificidade entre cepas e hospedeiros e indicam que a proximidade filogenética inferida entre cepas não necessariamente implica na capacidade de colonizar as mesmas espécies vegetais. Por exemplo, apesar de cepas de oleandro e videiras formarem um grupo monofilético (Schuenzel et al., 2005), nenhuma delas causa sintomas em experimentos de infecção com os hospedeiros trocados (Purcell et al., 1999). Já amendoeiras se mostraram susceptíveis a cepas obtidas de videiras, porém as videiras não apresentaram sintomas típicos quando inoculadas com cepas obtidas de amendoeiras (Almeida e Purcell, 2003). Analogamente, cepas isoladas de cafeeiros sintomáticos não foram capazes de colonizar plantas de citros, no entanto cepas obtidas deste último se mostraram capazes, mesmo que de forma limitada, a colonizar plantas de café (Almeida et al., 2008).

As taxas diferenciadas de recombinação existente entre cepas e/ou conjunto de cepas devem contribuir, pelo menos em parte, para a evolução convergente entre linhagens menos aparentadas e para a evolução divergente entre linhagens mais aparentadas, dando origem a genomas em forma de mosaico onde cada porção é oriunda de um genoma 
ancestral distinto (Almeida et al., 2008; Nunney et al., 2013). Sendo assim, a recombinação em $X$. fastidiosa representa um importante obstáculo em análises filogenéticas bifurcadas baseadas em sequências biológicas (Schierup e Hein, 2000; Posada e Crandall, 2002) e nossos resultados indicam que a plasticidade de regulons locais também é afetada pela recombinação, notadamente mais acentuada em cepas sul americanas.

A árvore obtida a partir dos valores de similaridade entre motivos correspondentes apresenta valores de suporte em seus nós ainda menores com apenas dois nós com mais de 70\% de bootstrap (figura 29), um deles separando três cepas norte americanas (GB514, Temecula1 e M23) do restante. Este resultado indica que a similaridade entre motivos correspondentes é altamente variável entre cepas e não obedece a um padrão congruente com a história filogenética inferida para a espécie (Schuenzel et al., 2005; Montero-Astua et al., 2007; Randall et al., 2009; Pierry, 2012). Pares de cepas com motivos altamente similares entre si também compartilham motivos altamente divergentes, aparentemente sem nenhuma ou muito pouca restrição em relação ao grau de parentesco existente entre elas. É possível de fato notar este fenômeno na árvore da figura 29, cujo baixo suporte de bootstrap para a maioria dos nós indica que a distribuição de similaridade entre motivos correspondentes é quase aleatória entre as cepas. Para explicar este resultado, sugerimos a existência de uma alta taxa de reciclagem de instâncias regulatórias em regiões não codificantes, isto é, rápido surgimento e desaparecimento de instâncias, seja por transferência lateral seja por mutações, que deve favorecer o estabelecimento da espécie em nichos ecológicos diversificados. Contudo, estudos mais direcionados são ainda necessários para corroborar esta hipótese.

A árvore obtida com os padrões de presença e ausência e similaridade entre motivos correspondentes é mostrada na figura 30. Ela apresenta dois grupos, que separam as cepas do norte das do sul, e 7 de seus nós apresentam $70 \%$ ou mais de suporte de bootstrap, assim como a árvore gerada apenas pelo padrão presença e ausência de motivos. Nenhuma diferença topológica significativa (em nós com $70 \%$ ou mais de suporte de bootstrap) é notada quando comparada à árvore de presença e ausência de motivos. Isto porque o número de motivos comuns aos 13 genomas é muito baixo, apenas 15 . Portanto, a contribuição dos valores de similaridade entre motivos correspondentes fica diluída pela contribuição do padrão de presença e ausência de motivos, já que a média o valor mínimo e o valor máximo de motivos por genoma de $X$. fastidiosa são 56.5, 37 e 80, respectivamente .

$\mathrm{Em}$ conjunto, os resultados das análises filogenéticas aqui apresentados sugerem uma considerável variabilidade de elementos cis-regulatórios em $X$. fastidiosa explicada, pelo menos em parte, pelas taxas diferenciadas de recombinação existentes entre cepas e/ou grupos de cepas (Almeida et al., 2008; Nunney et al., 2013). Esta variabilidade deve contribuir para a otimização dos níveis de expressão gênica e está potencialmente relacionada a particularidades fenotípicas como já discutido em tópicos anteriores deste trabalho (mutações em elementos cis-regulatórios com consequências fenotípicas em eucariotos são revisadas em (Wray, 2007)). 


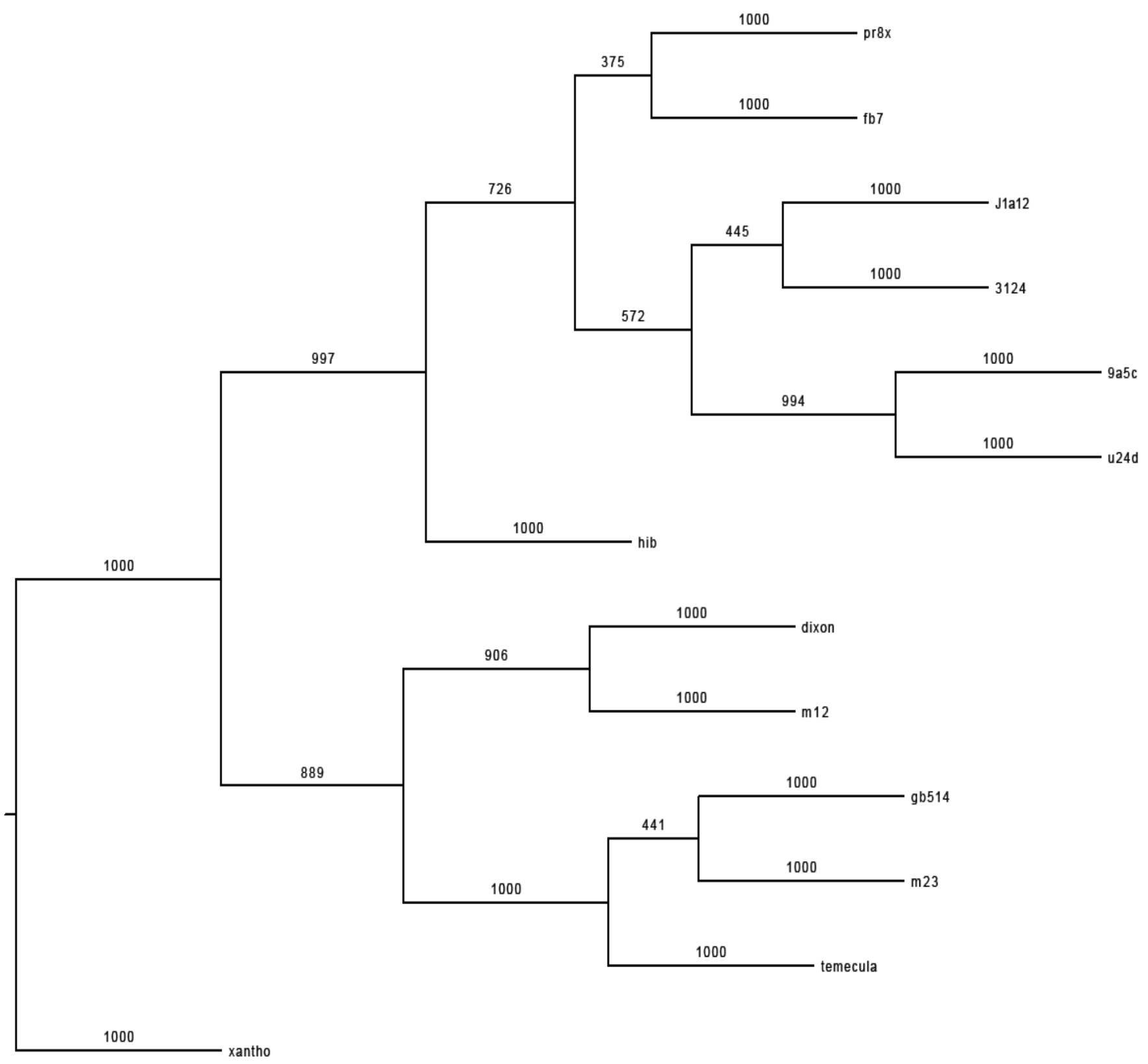

Figura 28: Árvore filogenética inferida a partir do padrão de presença e ausência de motivos regulatórios nos 12 genomas de $X$. fastidiosa e $X$. albilineans (grupo externo). A inferência foi realizada utilizando-se o método de neighbor-joining com 1000 pseudo-réplicas de bootstrap cujos valores são mostrados na árvore. 


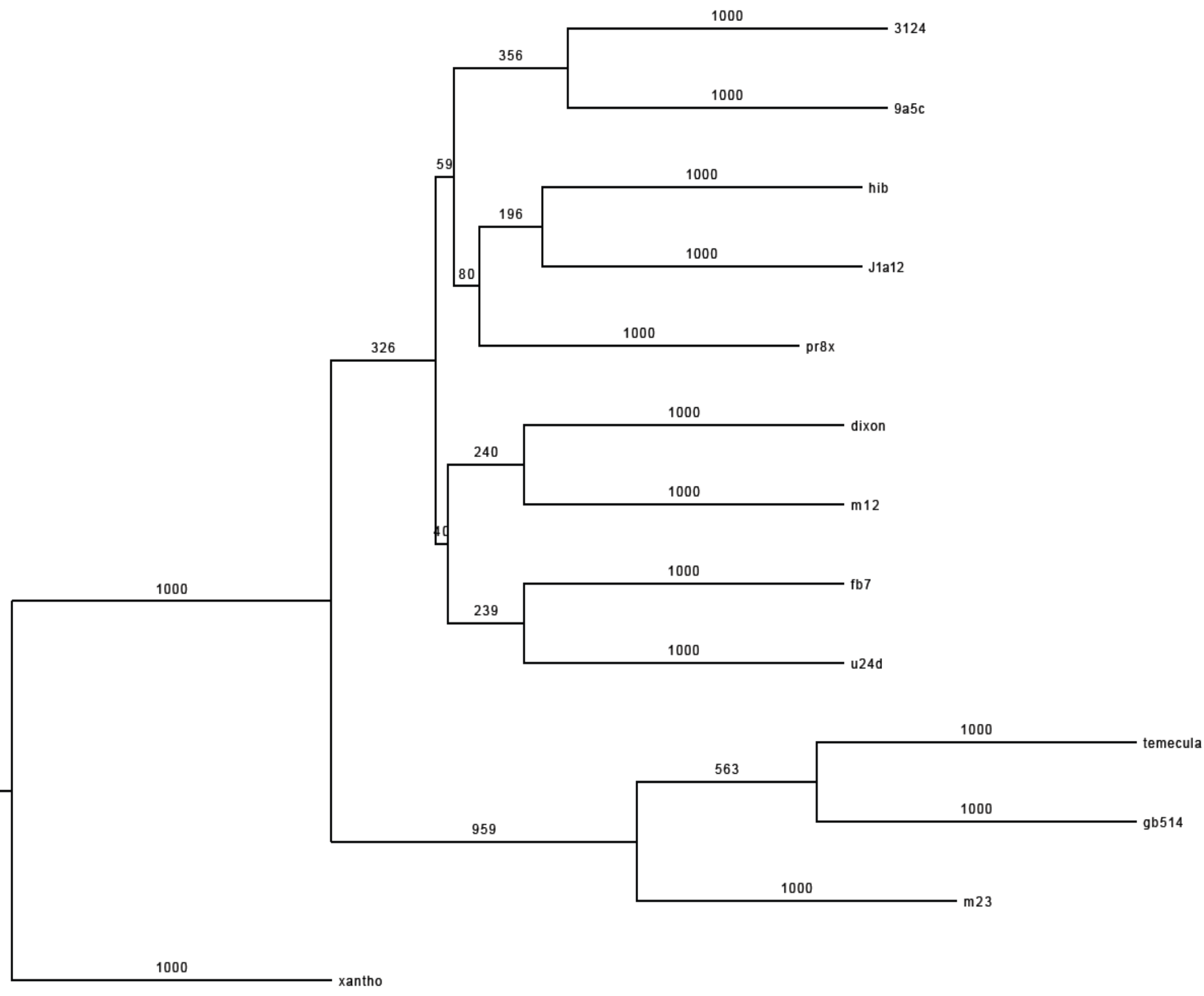

Figura 29: Árvore filogenética inferida a partir dos valores de similaridade entre motivos correspondentes, comuns aos 12 genomas de $X$. fastidiosa e $X$. albilineans (grupo externo). A inferência foi realizada utilizando-se o método de neighbor-joining com 1000 pseudo-réplicas de bootstrap cujos valores são mostrados na árvore. 


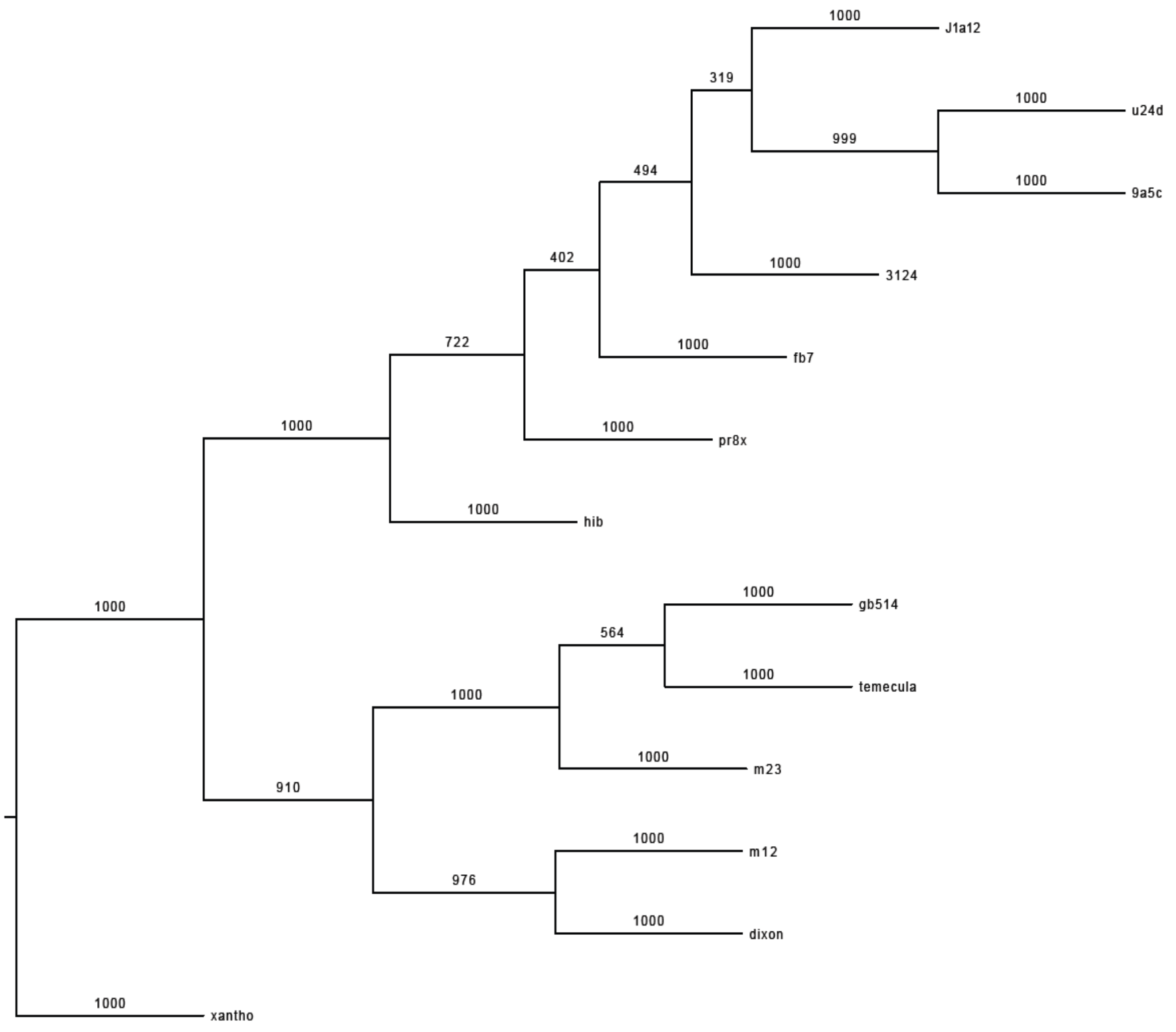

Figura 30: Árvore filogenética inferida a partir dos padrões de presença e ausência de motivos regulatórios e valores de similaridade entre motivos correspondentes, comuns aos 12 genomas de $\boldsymbol{X}$. fastidiosa e $\boldsymbol{X}$. albilineans (grupo externo). A inferência foi realizada utilizando-se o método de neighbor-joining com 1000 pseudo-réplicas de bootstrap cujos valores são mostrados na árvore. 


\section{Conclusões}

Com o intuito de caracterizar as sequências promotoras e arrecadar evidências para o melhor entendimento da dinâmica de regulação transcricional em $X$. fastidiosa duas estratégias para predição de elementos cis-regulatórios e duas estratégias de análise comparativa evolvendo cepas da espécie foram aplicadas no presente trabalho.

A transferência de informações regulatórias de E. coli para $X$. fastidiosa 9a5c permitiu a identificação de elementos cis-regulatórios em diversas regiões promotoras dos genes deste fitopatógeno, dos quais 4 já haviam sido anteriormente descritos. Em especial, ressaltamos a identificação de um sítio de Fur no promotor do gene codificador para um receptor de sideróforo, experimentalmente validado em outro estudo (Zaini et al., 2008). Como consequência, o conhecimento de 10 regulons foi expandido, cada qual enriquecido com funções gênicas em conformidade com a atuação dos respectivos reguladores transcricionais em outras bactérias. Interessantemente o regulon de Fur apresentou três genes que haviam sido reprimidos em condições experimentais com excesso de ferro, como esperado de uma regulação canônica por este TF, e 5 que haviam sido super-expressos na mesma condição, o que sugere que Fur também possa atuar como ativador em $X$. fastidiosa. Esta hipótese é suportada por estudos que observaram modulações análogas em um gene ortólogo (envolvido na síntese Fe-S cluster) e dois com funções relacionadas, em outras bactérias. Se comprovado, estas serão as primeiras descrições de ativação por Fur em $X$. fastidiosa e em fitopatógenos de modo geral.

Adicionalmente, destacamos o regulon de CRP enriquecido com genes relacionados à invasão e colonização do hospedeiro vegetal, entre eles diversos genes fimbriais responsáveis pela motilidade celular. Dessa forma, ressaltamos a importância de CRP não apenas como um regulador global, mas também regulador de genes efetores de patogenicidade. Devido à notória presença de genes envolvidos na biogênese do pilus longo do tipo IV e nenhum (identificado) relacionado à formação do pilus curto do tipo I, postulamos que o estresse decorrente da carência de fontes de carbono é um fator preponderante para a modulação da dispersão celular.

Os resultados obtidos com a predição $a b$ initio de elementos cis-regulatórios nos permitiu acessar a rede regulatória transcricional de $X$. fastidiosa de uma forma compreensiva (global). Foram estabelecidas 2990 interações regulatórias envolvendo 80 motivos regulatórios e $56.8 \%$ das TUs de $X$. fastidiosa 9a5c. Os resultados sugerem a existência de poucos TFs globais, responsáveis pela maioria das interações regulatórias, e diversos TFs locais, cada qual afetando um número limitado de TUs, como já notado em redes regulatórias de bactérias modelo como B. subtillis e E. coli. Além disso, com esta abordagem disponibilizamos informações a respeito de 80 regulons para os quais foram identificados putativos TFs cognatos, através de duas metodologias complementares, e categorias funcionais COG super-representadas (informações contidas em CD-ROM, distribuído como material suplementar). Esperamos que estes resultados sirvam de suporte para estudos futuros visando à elucidação de rotas metabólicas, anotação de genes, análises 
regulatórias, análise evolutivas de redes regulatórias transcricionais e motivos cisregulatórios, entre outros.

Os resultados da análise comparativa entre promotores das cepas 9a5c, um isolado virulento de citros, e Temecula1, um isolado virulento de videira, sugerem que genes envolvidos na comunicação com o meio externo estão sob diferentes mecanismos de controle transcricional nestas duas cepas e, portanto, devem responder diferencialmente a estímulos ambientais. Entre eles encontram-se diversos genes relacionados ao transporte de nutrientes, seletividade de moléculas, sistemas de secreção e biogênese da parede celular. Em especial, diferenças referentes a elementos cis-regulatórios foram detectadas em regiões promotoras de três enzimas envolvidas na síntese da camada de peptideoglicano, componente da parede celular bacteriana: succinyl-diaminopimelate desuccinylase, acetylCoA carboxylase e fosfoglucosamine mutase. As regiões promotoras das TUs codificadoras destas enzimas apresentaram sítios de Fis em Temecula1 que não foram detectados nas regiões promotoras correspondentes em 9a5c. Estes resultados suportam nossa hipótese de modulação diferenciada de genes envolvidos na comunicação com o meio externo nestas duas cepas.

Com a análise comparativa entre $9 \mathrm{a} 5 \mathrm{c}$ e $\mathrm{J1} 1 \mathrm{a} 12$, um isolado não virulento de citros, constatamos diferenças referentes a elementos cis-regulatórios em promotores de dois genes: um codificador putativo de bacteriocina, para o qual um sítio de Fur foi detectado no promotor em J1a12, mas não em 9a5c; e um repressor putativo de genes estruturais de bacteriófagos do tipo lambda, para o qual um sítio de Fur e um sítio de CRP parcialmente sobrepostos foram detectados em J1a12, mas não o foram em 9a5c. Interessantemente, notamos também uma diferença do número de cópias deste repressor putativo nos dois genomas: três cópias em J1a12 e duas cópias em 9a5c. Em E. coli esse repressor se mostrou responsável pela repressão do gene bacteriano $p c k A$ e está diretamente relacionado ao decaimento da taxa de crescimento celular em fontes de carbono alternativas à glicose. Sugerimos, desta forma, que o número de cópias funcionais e o controle transcricional diferenciado deste gene devem contribuir para diferenças fisiológicas entre $11 a 12,9 a 5 c$ e, possivelmente, outras cepas.

Por fim, os resultados de análises filogenéticas realizadas com motivos regulatórios em diferentes contextos sugerem uma considerável plasticidade dos mecanismos de regulação transcricional em $X$. fastidiosa explicada, pelo menos em parte, pelas taxas diferenciadas de recombinação existentes entre cepas e/ou grupos de cepas. Uma grande variabilidade foi detectada inclusive em motivos conservados, comuns aos 12 genomas de $X$. fastidiosa e ao genoma de Xanthomonas albilineans, utilizado como grupo externo. Além disso, o padrão de similaridade entre motivos correspondentes parece ser (quase) independente da história evolutiva subjacente às cepas utilizadas na análise, provavelmente devido à alta taxa de reciclagem (surgimento e desaparecimento) de instâncias regulatórias em regiões não codificantes. Acreditamos que tamanha plasticidade da rede regulatória transcricional seja ao mesmo tempo causa e consequência dos diferentes nichos ocupados pela espécie, contribuindo para a otimização dos níveis de expressão gênica requisitados em hospedeiros distintos e, consequentemente, para variabilidade fenotípica existente entre cepas. 


\section{Referências Bibliográficas}

1. Alamuri, P., Mehta, N., Burk, A. e Maier, R. J. 2006. Regulation of the Helicobacter pylori Fe-S cluster synthesis protein NifS by iron, oxidative stress conditions, and fur. J Bacteriol 188:5325-30.

2. Almeida, R. P., Nascimento, F. E., Chau, J., Prado, S. S., Tsai, C. W., Lopes, S. A. e Lopes, J. R. 2008. Genetic structure and biology of Xylella fastidiosa strains causing disease in citrus and coffee in Brazil. Appl Environ Microbiol 74:3690-701.

3. Almeida, R. P. e Purcell, A. H. 2003. Biological traits of Xylella fastidiosa strains from grapes and almonds. Appl Environ Microbiol 69:7447-52.

4. Almeida, R. P. P., Blua, M. J., Lopes, J. R. S. e Purcell, A. H. 2005. Vector transmission of Xylella fastidiosa: Applying fundamental knowledge to generate disease management strategies. Annals of the Entomological Society of America 98:775-786.

5. Almeida, R. P. P., Pereira, E. F., Purcell, A. H. e Lopes, J. R. S. 2001. Multiplication and movement of a citrus strain of Xylella fastidiosa within sweet orange. Plant Disease 85:382-386.

6. Alves, E., Kitajima, E. W. e Leite, B. 2003. Interaction of Xylella fastidiosa with different cultivars of Nicotiana tabacum: a comparison of colonization patterns. Journal of Phytopathology-Phytopathologische Zeitschrift 151:500-506.

7. Bagg, A. e Neilands, J. B. 1987. Ferric uptake regulation protein acts as a repressor, employing iron (II) as a cofactor to bind the operator of an iron transport operon in Escherichia coli. Biochemistry 26:5471-7.

8. Bailey, T. L., Boden, M., Buske, F. A., Frith, M., Grant, C. E., Clementi, L., Ren, J., Li, W. W. e Noble, W. S. 2009. MEME SUITE: tools for motif discovery and searching. Nucleic Acids Res 37:W202-8.

9. Bailey, T. L. e Gribskov, M. 1998. Combining evidence using p-values: application to sequence homology searches. Bioinformatics 14:48-54.

10. Bailey, T. L. a. E., C. . 1994. Fitting a mixture model by expectation maximization to discover motifs in biopolymers.

11. Balleza, E., Lopez-Bojorquez, L. N., Martinez-Antonio, A., Resendis-Antonio, O., Lozada-Chavez, I., Balderas-Martinez, Y. I., Encarnacion, S. e ColladoVides, J. 2009. Regulation by transcription factors in bacteria: beyond description. FEMS Microbiol Rev 33:133-51.

12. Barbosa, R. L. e Benedetti, C. E. 2007. BigR, a Transcriptional Repressor from Plant-Associated Bacteria, Regulates an Operon Implicated in Biofilm Growth. J Bacteriol.

13. Belda, E., Moya, A. e Silva, F. J. 2005. Genome rearrangement distances and gene order phylogeny in gamma-Proteobacteria. Mol Biol Evol 22:1456-67.

14. Benson, D. A., Karsch-Mizrachi, I., Clark, K., Lipman, D. J., Ostell, J. e Sayers, E. W. 2012. GenBank. Nucleic Acids Res 40:D48-53.

15. Bhattacharyya, A., Stilwagen, S., Ivanova, N., D'Souza, M., Bernal, A. et al. 2002a. Whole-genome comparative analysis of three phytopathogenic Xylella fastidiosa strains. Proc Natl Acad Sci U S A 99:12403-8.

16. Bhattacharyya, A., Stilwagen, S., Reznik, G., Feil, H., Feil, W. S. et al. 2002 b. Draft sequencing and comparative genomics of Xylella fastidiosa strains reveal novel biological insights. Genome Res 12:1556-63.

17. Born, T. L. e Blanchard, J. S. 1999. Structure/function studies on enzymes in the diaminopimelate pathway of bacterial cell wall biosynthesis. Curr Opin Chem Biol 3:607-13.

18. Bradley, M. D., Beach, M. B., de Koning, A. P., Pratt, T. S. e Osuna, R. 2007. Effects of Fis on Escherichia coli gene expression during different growth stages. Microbiology 153:2922-40.

19. Brazma, A., Jonassen, I., Eidhammer, I. e Gilbert, D. 1998. Approaches to the automatic discovery of patterns in biosequences. J Comput Biol 5:279-305.

20. Brouwer, R. W., Kuipers, O. P. e van Hijum, S. A. 2008. The relative value of operon predictions. Brief Bioinform 9:367-75.

21. Browning, D. F. e Busby, S. J. 2004. The regulation of bacterial transcription initiation. Nat Rev Microbiol 2:57-65. 
22. Browning, D. F., Grainger, D. C. e Busby, S. J. 2010. Effects of nucleoidassociated proteins on bacterial chromosome structure and gene expression. Curr Opin Microbiol 13:773-80.

23. Buck, M., Gallegos, M. T., Studholme, D. J., Guo, Y. e Gralla, J. D. 2000. The bacterial enhancer-dependent sigma(54) (sigma(N)) transcription factor. J Bacteriol 182:4129-36.

24. Bulyk, M. L. 2003. Computational prediction of transcription-factor binding site locations. Genome Biol 5:201.

25. Camilli, A. e Bassler, B. L. 2006. Bacterial small-molecule signaling pathways. Science 311:1113-6.

26. Campoy, S., Mazon, G., Fernandez de Henestrosa, A. R., Llagostera, M., Monteiro, P. B. e Barbe, J. 2002. A new regulatory DNA motif of the gamma subclass Proteobacteria: identification of the LexA protein binding site of the plant pathogen Xylella fastidiosa. Microbiology 148:3583-97.

27. Canchaya, C., Proux, C., Fournous, G., Bruttin, A. e Brussow, H. 2003. Prophage genomics. Microbiol Mol Biol Rev 67:238-76, table of contents.

28. Carpenter, B. M., Whitmire, J. M. e Merrell, D. S. 2009. This is not your mother's repressor: the complex role of fur in pathogenesis. Infect Immun 77:2590-601.

29. Casadesus, J. e Low, D. 2006. Epigenetic gene regulation in the bacterial world. Microbiol Mol Biol Rev 70:830-56.

30. Casjens, S. 2003. Prophages and bacterial genomics: what have we learned so far? Mol Microbiol 49:277-300.

31. Chatterjee, S., Almeida, R. P. e Lindow, S. 2008. Living in two worlds: the plant and insect lifestyles of Xylella fastidiosa. Annu Rev Phytopathol 46:243-71.

32. Chen, J., Xie, G., Han, S., Chertkov, O., Sims, D. e Civerolo, E. L. 2010. Whole genome sequences of two Xylella fastidiosa strains (M12 and M23) causing almond leaf scorch disease in California. J Bacteriol 192:4534.

33. Chen, Y., Golding, I., Sawai, S., Guo, L. e Cox, E. C. 2005. Population fitness and the regulation of Escherichia coli genes by bacterial viruses. PLoS Biol 3:e229.

34. Cho, B. K., Federowicz, S. A., Embree, M., Park, Y. S., Kim, D. e Palsson, B. 0. 2011. The PurR regulon in Escherichia coli K-12 MG1655. Nucleic Acids Res 39:645664.

35. Christman, M. F., Storz, G. e Ames, B. N. 1989. OxyR, a positive regulator of hydrogen peroxide-inducible genes in Escherichia coli and Salmonella typhimurium, is homologous to a family of bacterial regulatory proteins. Proc Natl Acad Sci U S A 86:3484-8.

36. Claeys, M., Storms, V., Sun, H., Michoel, T. e Marchal, K. 2012. MotifSuite: workflow for probabilistic motif detection and assessment. Bioinformatics 28:1931-2.

37. da Silva Neto, J. F., Koide, T., Abe, C. M., Gomes, S. L. e Marques, M. V. 2008. Role of sigma54 in the regulation of genes involved in type I and type IV pili biogenesis in Xylella fastidiosa. Arch Microbiol 189:249-61.

38. da Silva Neto, J. F., Koide, T., Gomes, S. L. e Marques, M. V. 2007. The single extracytoplasmic-function sigma factor of Xylella fastidiosa is involved in the heat shock response and presents an unusual regulatory mechanism. J Bacteriol 189:55160.

39. da Silva Neto, J. F., Koide, T., Gomes, S. L. e Marques, M. V. 2010. Global gene expression under nitrogen starvation in Xylella fastidiosa: contribution of the sigma54 regulon. BMC Microbiol 10:231.

40. da Silva, P. I. P. 2010. Identificação de genes com expressão modulada por estreptomicina e de genes associados à virulência e patogenicidade em Xylella fastidiosa. Tese de Doutorado. Departamento de Bioquímica, Instituto de Química, Universidade de São Paulo, São Paulo. 138.

41. Dam, P., Olman, V., Harris, K., Su, Z. e Xu, Y. 2007. Operon prediction using both genome-specific and general genomic information. Nucleic Acids Res 35:288-98.

42. De La Fuente, L., Burr, T. J. e Hoch, H. C. 2007a. Mutations in type I and type IV pilus biosynthetic genes affect twitching motility rates in Xylella fastidiosa. J Bacteriol 189:7507-10.

43. De La Fuente, L., Montanes, E., Meng, Y., Li, Y., Burr, T. J., Hoch, H. C. e Wu, M. 2007b. Assessing adhesion forces of type I and type IV pili of Xylella fastidiosa bacteria by use of a microfluidic flow chamber. Appl Environ Microbiol 73:2690-6.

44. de Mello Varani, A., de Lima, W. C., Moreira, L. M., Oliveira, M., Souza, R. C., Civerolo, E., Vasconcelos, A. T. R. e Van Sluys, M. A. 2009. Common Genes and Genomic Breaks: A Detailed Case Study of the Xylella fastidiosa Genome Backbone 
and Evolutionary Insights, p. 330. In R. W. Jackson (ed.), Plant Pathogenic Bacteria: Genomics and Molecular Biology. Caister Academic Press, Norwich.

45. de Mello Varani, A., Souza, R. C., Nakaya, H. I., de Lima, W. C., Paula de Almeida, L. G., Kitajima, E. W., Chen, J., Civerolo, E., Vasconcelos, A. T. e Van Sluys, M. A. 2008. Origins of the Xylella fastidiosa prophage-like regions and their impact in genome differentiation. PLoS ONE 3:e4059.

46. Delany, I., Rappuoli, R. e Scarlato, V. 2004. Fur functions as an activator and as a repressor of putative virulence genes in Neisseria meningitidis. Mol Microbiol 52:1081-90.

47. Dillon, S. C. e Dorman, C. J. 2010. Bacterial nucleoid-associated proteins, nucleoid structure and gene expression. Nat Rev Microbiol 8:185-95.

48. Djordjevic, M., Sengupta, A. M. e Shraiman, B. I. 2003. A biophysical approach to transcription factor binding site discovery. Genome Res 13:2381-90.

49. Dow, J. M. e Daniels, M. J. 2000. Xylella genomics and bacterial pathogenicity to plants. Yeast 17:263-71.

50. Espinosa, V., Gonzalez, A. D., Vasconcelos, A. T., Huerta, A. M. e ColladoVides, J. 2005. Comparative studies of transcriptional regulation mechanisms in a group of eight gamma-proteobacterial genomes. J Mol Biol 354:184-99.

51. Fadda, A., Fierro, A. C., Lemmens, K., Monsieurs, P., Engelen, K. e Marchal, K. 2009. Inferring the transcriptional network of Bacillus subtilis. Mol Biosyst 5:184052.

52. Fernandez De Henestrosa, A. R., Ogi, T., Aoyagi, S., Chafin, D., Hayes, J. J., Ohmori, H. e Woodgate, R. 2000. Identification of additional genes belonging to the LexA regulon in Escherichia coli. Mol Microbiol 35:1560-72.

53. Filenko, N., Spiro, S., Browning, D. F., Squire, D., Overton, T. W., Cole, J. e Constantinidou, C. 2007. The NsrR regulon of Escherichia coli K-12 includes genes encoding the hybrid cluster protein and the periplasmic, respiratory nitrite reductase. J Bacteriol 189:4410-7.

54. Galvani, C. D., Li, Y., Burr, T. J. e Hoch, H. C. 2007. Twitching motility among pathogenic Xylella fastidiosa isolates and the influence of bovine serum albumin on twitching-dependent colony fringe morphology. FEMS Microbiol Lett 268:202-8.

55. Gama-Castro, S., Jimenez-Jacinto, V., Peralta-Gil, M., Santos-Zavaleta, A., Penaloza-Spinola, M. I., Contreras-Moreira, B., Segura-Salazar, J., MunizRascado, L., Martinez-Flores, I., Salgado, H., Bonavides-Martinez, C., AbreuGoodger, C., Rodriguez-Penagos, C., Miranda-Rios, J., Morett, E., Merino, E., Huerta, A. M., Trevino-Quintanilla, L. e Collado-Vides, J. 2008. RegulonDB (version 6.0): gene regulation model of Escherichia coli $\mathrm{K}-12$ beyond transcription, active (experimental) annotated promoters and Textpresso navigation. Nucleic Acids Res 36:D120-4.

56. Gama-Castro, S., Salgado, H., Peralta-Gil, M., Santos-Zavaleta, A., MunizRascado, L. et al. 2011. RegulonDB version 7.0: transcriptional regulation of Escherichia coli K-12 integrated within genetic sensory response units (Gensor Units). Nucleic Acids Res 39:D98-105.

57. Gambetta, G. A., Fei, J., Rost, T. L. e Matthews, M. A. 2007. Leaf scorch symptoms are not correlated with bacterial populations during Pierce's disease. J Exp Bot 58:4037-46.

58. Georgopoulos, C. 1989. The E. coli dnaA initiation protein: a protein for all seasons. Trends Genet 5:319-21.

59. Gonzalez, A. D., Espinosa, V., Vasconcelos, A. T., Perez-Rueda, E. e ColladoVides, J. 2005. TRACTOR_DB: a database of regulatory networks in gammaproteobacterial genomes. Nucleic Acids Res 33:D98-102.

60. Gottig, N., Garavaglia, B. S., Garofalo, C. G., Orellano, E. G. e Ottado, J. 2009. A filamentous hemagglutinin-like protein of Xanthomonas axonopodis pv. citri, the phytopathogen responsible for citrus canker, is involved in bacterial virulence. PLoS One 4:e4358.

61. Govind, R., Vediyappan, G., Rolfe, R. D., Dupuy, B. e Fralick, J. A. 2009. Bacteriophage-mediated toxin gene regulation in Clostridium difficile. J Virol 83:12037-45.

62. Grainger, D. C., Hurd, D., Harrison, M., Holdstock, J. e Busby, S. J. 2005. Studies of the distribution of Escherichia coli cAMP-receptor protein and RNA polymerase along the E. coli chromosome. Proc Natl Acad Sci U S A 102:17693-8.

63. Gruber, T. M. e Gross, C. A. 2003. Multiple sigma subunits and the partitioning of bacterial transcription space. Annu Rev Microbiol 57:441-66. 
64. GuhaThakurta, D. 2006. Computational identification of transcriptional regulatory elements in DNA sequence. Nucleic Acids Res 34:3585-98.

65. Hall-Stoodley, L. e Stoodley, P. 2005. Biofilm formation and dispersal and the transmission of human pathogens. Trends Microbiol 13:7-10.

66. Helmann, J. D. 2002. The extracytoplasmic function (ECF) sigma factors. Adv Microb Physiol 46:47-110.

67. Herskowitz, I. 1973. Control of gene expression in bacteriophage lambda. Annu Rev Genet 7:289-324.

68. Hopkins, D. L. e Purcell, A. H. 2002. Xylella fastidiosa: Cause of Pierce's disease of grapevine and other emergent diseases. Plant Disease 86:1056-1066.

69. Hu, J., Li, B. e Kihara, D. 2005. Limitations and potentials of current motif discovery algorithms. Nucleic Acids Res 33:4899-913.

70. Hughes, J. D., Estep, P. W., Tavazoie, S. e Church, G. M. 2000. Computational identification of cis-regulatory elements associated with groups of functionally related genes in Saccharomyces cerevisiae. J Mol Biol 296:1205-14.

71. Huse, S. M., Huber, J. A., Morrison, H. G., Sogin, M. L. e Welch, D. M. 2007. Accuracy and quality of massively parallel DNA pyrosequencing. Genome Biol 8:R143.

72. Itoh, T., Takemoto, K., Mori, H. e Gojobori, T. 1999. Evolutionary instability of operon structures disclosed by sequence comparisons of complete microbial genomes. Mol Biol Evol 16:332-46.

73. Janky, R., Helden, J. e Babu, M. M. 2009. Investigating transcriptional regulation: from analysis of complex networks to discovery of cis-regulatory elements. Methods 48:277-86.

74. Jolly, L., Ferrari, P., Blanot, D., Van Heijenoort, J., Fassy, F. e MenginLecreulx, D. 1999. Reaction mechanism of phosphoglucosamine mutase from Escherichia coli. Eur J Biochem 262:202-10.

75. Jones, J. D. e Dangl, J. L. 2006. The plant immune system. Nature 444:323-9.

76. Karp, P. D., Keseler, I. M., Shearer, A., Latendresse, M., Krummenacker, M., Paley, S. M., Paulsen, I., Collado-Vides, J., Gama-Castro, S., Peralta-Gil, M., Santos-Zavaleta, A., Penaloza-Spinola, M. I., Bonavides-Martinez, C. e Ingraham, J. 2007. Multidimensional annotation of the Escherichia coli K-12 genome. Nucleic Acids Res 35:7577-90.

77. Kazakov, A. E., Cipriano, M. J., Novichkov, P. S., Minovitsky, S., Vinogradov, D. V., Arkin, A., Mironov, A. A., Gelfand, M. S. e Dubchak, I. 2007. RegTransBase - a database of regulatory sequences and interactions in a wide range of prokaryotic genomes. Nucleic Acids Research 35:D407-D412.

78. Kelly, A., Goldberg, M. D., Carroll, R. K., Danino, V., Hinton, J. C. e Dorman, C. J. 2004. A global role for Fis in the transcriptional control of metabolism and type III secretion in Salmonella enterica serovar Typhimurium. Microbiology 150:2037-53.

79. Killiny, N. e Almeida, R. P. 2009. Host structural carbohydrate induces vector transmission of a bacterial plant pathogen. Proc Natl Acad Sci U S A 106:22416-20.

80. Koebnik, R., Locher, K. P. e Van Gelder, P. 2000. Structure and function of bacterial outer membrane proteins: barrels in a nutshell. Mol Microbiol 37:239-53.

81. Koide, T., Vencio, R. Z. e Gomes, S. L. 2006. Global gene expression analysis of the heat shock response in the phytopathogen Xylella fastidiosa. J Bacteriol 188:5821-30.

82. Koide, T., Zaini, P. A., Moreira, L. M., Vencio, R. Z., Matsukuma, A. Y., Durham, A. M., Teixeira, D. C., El-Dorry, H., Monteiro, P. B., da Silva, A. C., Verjovski-Almeida, S., da Silva, A. M. e Gomes, S. L. 2004. DNA microarraybased genome comparison of a pathogenic and a nonpathogenic strain of Xylella fastidiosa delineates genes important for bacterial virulence. J Bacteriol 186:5442-9.

83. Lambais, M. R., Goldman, M. H., Camargo, L. E. e Goldman, G. H. 2000. A genomic approach to the understanding of Xylella fastidiosa pathogenicity. Curr Opin Microbiol 3:459-62.

84. Lathe, W. C., 3rd, Snel, B. e Bork, P. 2000. Gene context conservation of a higher order than operons. Trends Biochem Sci 25:474-9.

85. Lawson, C. L., Swigon, D., Murakami, K. S., Darst, S. A., Berman, H. M. e Ebright, R. H. 2004. Catabolite activator protein: DNA binding and transcription activation. Curr Opin Struct Biol 14:10-20.

86. Lerat, E., Daubin, V., Ochman, H. e Moran, N. A. 2005. Evolutionary origins of genomic repertoires in bacteria. PLoS Biol 3:e130.

87. Li, G., Liu, B. e Xu, Y. 2010. Accurate recognition of cis-regulatory motifs with the correct lengths in prokaryotic genomes. Nucleic Acids Res 38:e12. 
88. Li, N. e Tompa, M. 2006. Analysis of computational approaches for motif discovery. Algorithms Mol Biol 1:8.

89. Li, W. B., Zreik, L., Fernandes, N. G., Miranda, V. S., Teixeira, D. C., Ayres, A. J., Garnier, M. e Bov, J. M. 1999. A triply cloned strain of Xylella fastidiosa multiplies and induces symptoms of citrus variegated chlorosis in sweet orange. Curr Microbiol 39:106-8.

90. Li, Y., Hao, G., Galvani, C. D., Meng, Y., De La Fuente, L., Hoch, H. C. e Burr, T. J. 2007. Type I and type IV pili of Xylella fastidiosa affect twitching motility, biofilm formation and cell-cell aggregation. Microbiology 153:719-26.

91. Lin, H., Doddapaneni, H., Takahashi, Y. e Walker, M. A. 2007. Comparative analysis of ESTs involved in grape responses to Xylella fastidiosa infection. BMC Plant Biol 7:8.

92. Liu, J., Xu, X. e Stormo, G. D. 2008. The cis-regulatory map of Shewanella genomes. Nucleic Acids Res 36:5376-90.

93. Liu, X., Brutlag, D. L. e Liu, J. S. 2001. BioProspector: discovering conserved DNA motifs in upstream regulatory regions of co-expressed genes. Pac Symp Biocomput:127-38.

94. Lory, S. 1986. Effect of iron on accumulation of exotoxin A-specific mRNA in Pseudomonas aeruginosa. J Bacteriol 168:1451-6.

95. Luke, N. R., Howlett, A. J., Shao, J. e Campagnari, A. A. 2004. Expression of type IV pili by Moraxella catarrhalis is essential for natural competence and is affected by iron limitation. Infect Immun 72:6262-70.

96. Maamar, H., Raj, A. e Dubnau, D. 2007. Noise in gene expression determines cell fate in Bacillus subtilis. Science 317:526-9.

97. MacIsaac, K. D. e Fraenkel, E. 2006. Practical strategies for discovering regulatory DNA sequence motifs. PLoS Comput Biol 2:e36.

98. Markowitz, V. M., Chen, I. M., Palaniappan, K., Chu, K., Szeto, E., Grechkin, Y., Ratner, A., Jacob, B., Huang, J., Williams, P., Huntemann, M., Anderson, I., Mavromatis, K., Ivanova, N. N. e Kyrpides, N. C. 2012. IMG: the Integrated Microbial Genomes database and comparative analysis system. Nucleic Acids Res 40:D115-22.

99. Martinez-Antonio, A. e Collado-Vides, J. 2003. Identifying global regulators in transcriptional regulatory networks in bacteria. Curr Opin Microbiol 6:482-9.

100. Masse, E. e Gottesman, S. 2002. A small RNA regulates the expression of genes involved in iron metabolism in Escherichia coli. Proc Natl Acad Sci U S A 99:4620-5.

101. McCue, L., Thompson, W., Carmack, C., Ryan, M. P., Liu, J. S., Derbyshire, V. e Lawrence, C. E. 2001. Phylogenetic footprinting of transcription factor binding sites in proteobacterial genomes. Nucleic Acids Res 29:774-82.

102. McCue, L. A., Thompson, W., Carmack, C. S. e Lawrence, C. E. 2002. Factors influencing the identification of transcription factor binding sites by cross-species comparison. Genome Res 12:1523-32.

103. McGuire, A. M., Hughes, J. D. e Church, G. M. 2000. Conservation of DNA regulatory motifs and discovery of new motifs in microbial genomes. Genome Res 10:744-57.

104. Mehta, A., Leite, R. P., Jr. e Rosato, Y. B. 2001. Assessment of the genetic diversity of Xylella fastidiosa isolated from citrus in Brazil by PCR-RFLP of the 16S rDNA and 16S-23S intergenic spacer and rep-PCR fingerprinting. Antonie Van Leeuwenhoek 79:53-9.

105. Mehta, A. e Rosato, Y. B. 2001. Phylogenetic relationships of Xylella fastidiosa strains from different hosts, based on 16S rDNA and 16S-23S intergenic spacer sequences. Int J Syst Evol Microbiol 51:311-8.

106. Meng, Y., Li, Y., Galvani, C. D., Hao, G., Turner, J. N., Burr, T. J. e Hoch, H. C. 2005. Upstream migration of Xylella fastidiosa via pilus-driven twitching motility. J Bacteriol 187:5560-7.

107. Miyashiro, T. e Goulian, M. 2007. Stimulus-dependent differential regulation in the Escherichia coli PhoQ PhoP system. Proc Natl Acad Sci U S A 104:16305-10.

108. Mole, B. M., Baltrus, D. A., Dangl, J. L. e Grant, S. R. 2007. Global virulence regulation networks in phytopathogenic bacteria. Trends Microbiol 15:363-71.

109. Monsieurs, P., De Keersmaecker, S., Navarre, W. W., Bader, M. W., De Smet, F., McClelland, M., Fang, F. C., De Moor, B., Vanderleyden, J. e Marchal, K. 2005. Comparison of the PhoPQ regulon in Escherichia coli and Salmonella typhimurium. J Mol Evol 60:462-74. 
110. Monteiro, P. B., Teixeira, D. C., Palma, R. R., Garnier, M., Bove, J. M. e Renaudin, J. 2001. Stable transformation of the Xylella fastidiosa citrus variegated chlorosis strain with oriC plasmids. Appl Environ Microbiol 67:2263-9.

111. Montero-Astua, M., Hartung, J. S., Aguilar, E., Chacon, C., Li, W., Albertazzi, F. J. e Rivera, C. 2007. Genetic Diversity of Xylella fastidiosa Strains from Costa Rica, Sao Paulo, Brazil, and United States. Phytopathology 97:1338-47.

112. Munch, R., Hiller, K., Barg, H., Heldt, D., Linz, S., Wingender, E. e Jahn, D. 2003. PRODORIC: prokaryotic database of gene regulation. Nucleic Acids Res $31: 266-9$.

113. Newman, K. L., Almeida, R. P., Purcell, A. H. e Lindow, S. E. 2003. Use of a green fluorescent strain for analysis of Xylella fastidiosa colonization of Vitis vinifera. Appl Environ Microbiol 69:7319-27.

114. Novichkov, P. S., Laikova, O. N., Novichkova, E. S., Gelfand, M. S., Arkin, A. P., Dubchak, I. e Rodionov, D. A. 2010a. RegPrecise: a database of curated genomic inferences of transcriptional regulatory interactions in prokaryotes. Nucleic Acids Res 38:D111-8.

115. Novichkov, P. S., Rodionov, D. A., Stavrovskaya, E. D., Novichkova, E. S., Kazakov, A. E., Gelfand, M. S., Arkin, A. P., Mironov, A. A. e Dubchak, I. 2010b. RegPredict: an integrated system for regulon inference in prokaryotes by comparative genomics approach. Nucleic Acids Res 38:W299-307.

116. Nunney, L., Vickerman, D. B., Bromley, R. E., Russell, S. A., Hartman, J. R., Morano, L. D. e Stouthamer, R. 2013. Recent Evolutionary Radiation and Host Plant Specialization in the Xylella fastidiosa Subspecies Native to the United States. Appl Environ Microbiol 79:2189-200.

117. Osborne, S. E., Walthers, D., Tomljenovic, A. M., Mulder, D. T., Silphaduang, U., Duong, N., Lowden, M. J., Wickham, M. E., Waller, R. F., Kenney, L. J. e Coombes, B. K. 2009. Pathogenic adaptation of intracellular bacteria by rewiring a cis-regulatory input function. Proc Natl Acad Sci U S A 106:3982-7.

118. Pashalidis, S., Moreira, L. M., Zaini, P. A., Campanharo, J. C., Alves, L. M., Ciapina, L. P., Vencio, R. Z., Lemos, E. G., Da Silva, A. M. e Da Silva, A. C. 2005. Whole-genome expression profiling of Xylella fastidiosa in response to growth on glucose. Omics 9:77-90.

119. Paul, J. H. 2008. Prophages in marine bacteria: dangerous molecular time bombs or the key to survival in the seas? ISME J 2:579-89.

120. Pavesi, G., Mauri, G. e Pesole, G. 2004. In silico representation and discovery of transcription factor binding sites. Brief Bioinform 5:217-36.

121. Perez-Donoso, A. G., Sun, Q., Roper, M. C., Greve, L. C., Kirkpatrick, B. e Labavitch, J. M. 2010. Cell wall-degrading enzymes enlarge the pore size of intervessel pit membranes in healthy and Xylella fastidiosa-infected grapevines. Plant Physiol 152:1748-59.

122. Perez, A. G., Angarica, V. E., Vasconcelos, A. T. e Collado-Vides, J. 2007. Tractor_DB (version 2.0): a database of regulatory interactions in gammaproteobacterial genomes. Nucleic Acids Res 35:D132-6.

123. Pieretti, I., Royer, M., Barbe, V., Carrere, S., Koebnik, R., Cociancich, S., Couloux, A., Darrasse, A., Gouzy, J., Jacques, M. A., Lauber, E., Manceau, C., Mangenot, S., Poussier, S., Segurens, B., Szurek, B., Verdier, V., Arlat, M. e Rott, P. 2009. The complete genome sequence of Xanthomonas albilineans provides new insights into the reductive genome evolution of the xylem-limited Xanthomonadaceae. BMC Genomics 10:616.

124. Pierry, P. M. 2012. Pirossequenciamento e análise comparativa de genomas do fitopatógeno Xylella fastidiosa. Dissertação de Mestrado. Departamento de Bioquímica, USP, São Paulo. 144.

125. Pizarro-Cerda, J., Moreno, E., Sanguedolce, V., Mege, J. L. e Gorvel, J. P. 1998. Virulent Brucella abortus prevents lysosome fusion and is distributed within autophagosome-like compartments. Infect Immun 66:2387-92.

126. Posada, D. e Crandall, K. A. 2002. The effect of recombination on the accuracy of phylogeny estimation. J Mol Evol 54:396-402.

127. Price, M. N., Arkin, A. P. e Alm, E. J. 2006. The life-cycle of operons. PLoS Genet 2:e96.

128. Purcell, A. H. e Hopkins, D. L. 1996. Fastidious xylem-limited bacterial plant pathogens. Annual Review of Phytopathology 34:131-151.

129. Purcell, A. H. e Saunders, S. R. 1999. Fate of Pierce's disease strains of Xylella fastidiosa in common riparian plants in California. Plant Disease 83:825-830. 
130. Purcell, A. H., Saunders, S. R., Hendson, M., Grebus, M. E. e Henry, M. J. 1999. Causal role of Xylella fastidiosa in oleander leaf scorch disease. Phytopathology 89:53-58.

131. Purcino, R. P., Medina, C. L., Martins de Souza, D., Winck, F. V., Machado, E. C., Novello, J. C., Machado, M. A. e Mazzafera, P. 2007. Xylella fastidiosa disturbs nitrogen metabolism and causes a stress response in sweet orange Citrus sinensis cv. Pera. J Exp Bot 58:2733-44.

132. Qin, X. T., Miranda, V. S., Machado, M. A., Lemos, E. G. M. e Hartung, J. S. 2001. An evaluation of the genetic diversity of Xylella fastidiosa isolated from diseased citrus and coffee in Sao Paulo, Brazil. Phytopathology 91:599-605.

133. Ramey, B. E., Koutsoudis, M., von Bodman, S. B. e Fuqua, C. 2004. Biofilm formation in plant-microbe associations. Curr Opin Microbiol 7:602-9.

134. Randall, J. J., Goldberg, N. P., Kemp, J. D., Radionenko, M., French, J. M., Olsen, M. W. e Hanson, S. F. 2009. Genetic analysis of a novel Xylella fastidiosa subspecies found in the southwestern United States. Appl Environ Microbiol 75:56318.

135. Ratledge, C. e Dover, L. G. 2000. Iron metabolism in pathogenic bacteria. Annu Rev Microbiol 54:881-941.

136. Ravcheev, D. A., Best, A. A., Tintle, N., Dejongh, M., Osterman, A. L., Novichkov, P. S. e Rodionov, D. A. 2011. Inference of the transcriptional regulatory network in Staphylococcus aureus by integration of experimental and genomics-based evidence. J Bacteriol 193:3228-40.

137. Redak, R. A., Purcell, A. H., Lopes, J. R., Blua, M. J., Mizell, R. F. e Andersen, P. C. 2004. The biology of xylem fluid-feeding insect vectors of Xylella fastidiosa and their relation to disease epidemiology. Annu Rev Entomol 49:243-70.

138. Remm, M., Storm, C. E. V. e Sonnhammer, E. L. L. 2001. Automatic clustering of orthologs and in-paralogs from pairwise species comparisons. Journal of Molecular Biology 314:1041-1052.

139. Rice, P., Longden, I. e Bleasby, A. 2000. EMBOSS: the European Molecular Biology Open Software Suite. Trends Genet 16:276-7.

140. Riley, M. A. e Wertz, J. E. 2002. Bacteriocins: evolution, ecology, and application. Annu Rev Microbiol 56:117-37.

141. Rodionov, D. A. 2007. Comparative genomic reconstruction of transcriptional regulatory networks in bacteria. Chem Rev 107:3467-97.

142. Rodionov, D. A., Novichkov, P. S., Stavrovskaya, E. D., Rodionova, I. A., Li, X., Kazanov, M. D., Ravcheev, D. A., Gerasimova, A. V., Kazakov, A. E., Kovaleva, G. Y., Permina, E. A., Laikova, O. N., Overbeek, R., Romine, M. F., Fredrickson, J. K., Arkin, A. P., Dubchak, I., Osterman, A. L. e Gelfand, M. S. 2011. Comparative genomic reconstruction of transcriptional networks controlling central metabolism in the Shewanella genus. BMC Genomics 12 Suppl 1:S3.

143. Rodrigues, J. L., Silva-Stenico, M. E., Gomes, J. E., Lopes, J. R. e Tsai, S. M. 2003. Detection and diversity assessment of Xylella fastidiosa in field-collected plant and insect samples by using $16 \mathrm{~S}$ rRNA and gyrB sequences. Appl Environ Microbiol 69:4249-55.

144. Rogozin, I. B., Makarova, K. S., Wolf, Y. I. e Koonin, E. V. 2004. Computational approaches for the analysis of gene neighbourhoods in prokaryotic genomes. Brief Bioinform 5:131-49.

145. Ross, W., Thompson, J. F., Newlands, J. T. e Gourse, R. L. 1990. E.coli Fis protein activates ribosomal RNA transcription in vitro and in vivo. EMBO J 9:3733-42.

146. Saitou, N. e Nei, M. 1987. The neighbor-joining method: a new method for reconstructing phylogenetic trees. Mol Biol Evol 4:406-25.

147. Sandve, G. K. e Drablos, F. 2006. A survey of motif discovery methods in an integrated framework. Biol Direct 1:11.

148. Santana, W. 2013. Genômica Comparativa de Xylella fastidiosa: Diversidade do Pangenoma e Análise de Genes de Patogenicidade. Tese de Doutorado. Departamento de Bioquímica, USP, São Paulo. 155.

149. Schaad, N. W., Postnikova, E., Lacy, G., Fatmi, M. e Chang, C. J. 2004. Xylella fastidiosa subspecies: $X$. fastidiosa subsp piercei, subsp. nov., $X$. fastidiosa subsp. multiplex subsp. nov., and $X$. fastidiosa subsp. pauca subsp. nov. Syst Appl Microbiol 27:290-300.

150. Schierup, M. H. e Hein, J. 2000. Consequences of recombination on traditional phylogenetic analysis. Genetics 156:879-91. 
151. Schreiber, H. L. I., Koirala, M., Lara, A., Ojeda, M., Dowd, S. E., Bextine, B. e Morano, L. 2010. Unraveling the first Xylella fastidiosa subsp. fastidiosa genome from Texas. Southwestern Entomologist 35:479-483.

152. Schuenzel, E. L., Scally, M., Stouthamer, R. e Nunney, L. 2005. A multigene phylogenetic study of clonal diversity and divergence in North American strains of the plant pathogen Xylella fastidiosa. Appl Environ Microbiol 71:3832-9.

153. Shavkunov, K. S., Masulis, I. S., Tutukina, M. N., Deev, A. A. e Ozoline, O. N. 2009. Gains and unexpected lessons from genome-scale promoter mapping. Nucleic Acids Res 37:4919-31.

154. Shi, X. Y., Dumenyo, C. K., Hernandez-Martinez, R., Azad, H. e Cooksey, D. A. 2007. Characterization of regulatory pathways in Xylella fastidiosa: genes and phenotypes controlled by algU. Appl Environ Microbiol 73:6748-56.

155. Shi, X. Y., Dumenyo, C. K., Hernandez-Martinez, R., Azad, H. e Cooksey, D. A. 2009. Characterization of regulatory pathways in Xylella fastidiosa: genes and phenotypes controlled by gacA. Appl Environ Microbiol 75:2275-83.

156. Siddharthan, R., Siggia, E. D. e van Nimwegen, E. 2005. PhyloGibbs: a Gibbs sampling motif finder that incorporates phylogeny. PLoS Comput Biol 1:e67.

157. Sierro, N., Makita, Y., de Hoon, M. e Nakai, K. 2008. DBTBS: a database of transcriptional regulation in Bacillus subtilis containing upstream intergenic conservation information. Nucleic Acids Res 36:D93-6.

158. Silander, O. K., Nikolic, N., Zaslaver, A., Bren, A., Kikoin, I., Alon, U. e Ackermann, M. 2012. A genome-wide analysis of promoter-mediated phenotypic noise in Escherichia coli. PLoS Genet 8:e1002443.

159. Silva-Stenico, M. E., Pacheco, F. T. H., Pereira, E. R., Rodrigues, J. L. M., Souza, A. N., Etchegaray, A., Gomes, J. E. e Tsai, S. M. 2009. Nutritional deficiency in citrus with symptoms of citrus variegated chlorosis disease. Brazilian Journal of Biology 69:861-866.

160. Simpson, A. J., Reinach, F. C., Arruda, P., Abreu, F. A., Acencio, M. et al. 2000. The genome sequence of the plant pathogen Xylella fastidiosa. Nature 406:151-7.

161. Smith, T. F. e Waterman, M. S. 1981. Identification of common molecular subsequences. J Mol Biol 147:195-7.

162. Stormo, G. D. 2000. DNA binding sites: representation and discovery. Bioinformatics 16:16-23.

163. Tamames, J. 2001. Evolution of gene order conservation in prokaryotes. Genome Biol 2:RESEARCH0020.

164. Tan, K., McCue, L. A. e Stormo, G. D. 2005. Making connections between novel transcription factors and their DNA motifs. Genome Res 15:312-20.

165. Tan, K., Moreno-Hagelsieb, G., Collado-Vides, J. e Stormo, G. D. 2001. A comparative genomics approach to prediction of new members of regulons. Genome Res 11:566-84.

166. Thijs, G., Marchal, K., Lescot, M., Rombauts, S., De Moor, B., Rouze, P. e Moreau, Y. 2002. A Gibbs sampling method to detect overrepresented motifs in the upstream regions of coexpressed genes. J Comput Biol 9:447-64.

167. Tompa, M., Li, N., Bailey, T. L., Church, G. M., De Moor, B. et al. 2005. Assessing computational tools for the discovery of transcription factor binding sites. Nat Biotechnol 23:137-44.

168. Touchon, M., Hoede, C., Tenaillon, O., Barbe, V., Baeriswyl, S. et al. 2009. Organised genome dynamics in the Escherichia coli species results in highly diverse adaptive paths. PLoS Genet 5:e1000344.

169. Tseng, T. T., Tyler, B. M. e Setubal, J. C. 2009. Protein secretion systems in bacterial-host associations, and their description in the Gene Ontology. BMC Microbiol 9 Suppl 1:S2.

170. van Hijum, S. A., Medema, M. H. e Kuipers, O. P. 2009. Mechanisms and evolution of control logic in prokaryotic transcriptional regulation. Microbiol Mol Biol Rev 73:481-509, Table of Contents.

171. Van Sluys, M. A., de Oliveira, M. C., Monteiro-Vitorello, C. B., Miyaki, C. Y., Furlan, L. R. et al. 2003. Comparative analyses of the complete genome sequences of Pierce's disease and citrus variegated chlorosis strains of Xylella fastidiosa. J Bacteriol 185:1018-26.

172. Van Sluys, M. A., Monteiro-Vitorello, C. B., Camargo, L. E., Menck, C. F., Da Silva, A. C., Ferro, J. A., Oliveira, M. C., Setubal, J. C., Kitajima, J. P. e Simpson, A. J. 2002. Comparative genomic analysis of plant-associated bacteria. Annu Rev Phytopathol 40:169-89. 
173. Vidgen, M., Carson, J., Higgins, M. e Owens, L. 2006. Changes to the phenotypic profile of Vibrio harveyi when infected with the Vibrio harveyi myovirus-like (VHML) bacteriophage. J Appl Microbiol 100:481-7.

174. Vuong, C., Kocianova, S., Voyich, J. M., Yao, Y., Fischer, E. R., DeLeo, F. R. e Otto, M. 2004. A crucial role for exopolysaccharide modification in bacterial biofilm formation, immune evasion, and virulence. J Biol Chem 279:54881-6.

175. Wasserman, W. W. e Sandelin, A. 2004. Applied bioinformatics for the identification of regulatory elements. Nat Rev Genet 5:276-87.

176. Wee, S., Neilands, J. B., Bittner, M. L., Hemming, B. C., Haymore, B. L. e Seetharam, R. 1988. Expression, isolation and properties of Fur (ferric uptake regulation) protein of Escherichia coli K 12. Biol Met 1:62-8.

177. Wels, M., Francke, C., Kerkhoven, R., Kleerebezem, M. e Siezen, R. J. 2006. Predicting cis-acting elements of Lactobacillus plantarum by comparative genomics with different taxonomic subgroups. Nucleic Acids Res 34:1947-58.

178. Wilderman, P. J., Sowa, N. A., FitzGerald, D. J., FitzGerald, P. C., Gottesman, S., Ochsner, U. A. e Vasil, M. L. 2004. Identification of tandem duplicate regulatory small RNAs in Pseudomonas aeruginosa involved in iron homeostasis. Proc Natl Acad Sci U S A 101:9792-7.

179. Wilson, D., Charoensawan, V., Kummerfeld, S. K. e Teichmann, S. A. 2008. DBD--taxonomically broad transcription factor predictions: new content and functionality. Nucleic Acids Res 36:D88-92.

180. Woese, C. R. 1987. Bacterial evolution. Microbiol Rev 51:221-71.

181. Wray, G. A. 2007. The evolutionary significance of cis-regulatory mutations. Nat Rev Genet 8:206-16.

182. Yamada, M., Makino, K., Amemura, M., Shinagawa, H. e Nakata, A. 1989. Regulation of the phosphate regulon of Escherichia coli: analysis of mutant phoB and phoR genes causing different phenotypes. J Bacteriol 171:5601-6.

183. Yu, H. e Gerstein, M. 2006. Genomic analysis of the hierarchical structure of regulatory networks. Proc Natl Acad Sci U S A 103:14724-31.

184. Yu, J., Penaloza-Vazquez, A., Chakrabarty, A. M. e Bender, C. L. 1999. Involvement of the exopolysaccharide alginate in the virulence and epiphytic fitness of Pseudomonas syringae pv. syringae. Mol Microbiol 33:712-20.

185. Zaini, P. A., Fogaca, A. C., Lupo, F. G., Nakaya, H. I., Vencio, R. Z. e da Silva, A. M. 2008. The iron stimulon of Xylella fastidiosa includes genes for type IV pilus and colicin V-like bacteriocins. J Bacteriol 190:2368-78.

186. Zhang, H., Yin, Y., Olman, V. e Xu, Y. 2012. Genomic arrangement of regulons in bacterial genomes. PLoS One 7:e29496.

187. Zhang, S., Flores-Cruz, Z., Kumar, D., Chakrabarty, P., Hopkins, D. L. e Gabriel, D. W. 2011. The Xylella fastidiosa biocontrol strain EB92-1 genome is very similar and syntenic to Pierce's disease strains. J Bacteriol 193:5576-7.

188. Zhang, S., Xu, M., Li, S. e Su, Z. 2009. Genome-wide de novo prediction of cisregulatory binding sites in prokaryotes. Nucleic Acids Res 37:e72. 


\section{Anexos}

Anexo 1. Promotores entre as cepas $9 a 5 \mathrm{c}$ e Temecula 1 com diferenças significativas (críticos). Genes com asteriscos (*) indicam genes compartilhados pelas TUs cujos promotores foram comparados. Os genes são descritos por suas funções seguidas pelos seus identificadores entre chaves. As informações foram extraídas da plataforma IMG-ER do JGI, utilizada para padronizar a anotação dos genomas. TUs em negrito (duas primeiras colunas) indicam promotores para os quais foram detectadas diferenças consideradas relevantes, relacionadas a elementos cis-regulatórios.

\begin{tabular}{|c|c|c|c|c|}
\hline $\begin{array}{l}\text { Gene de Temecula1 vizinho ao } \\
\text { promotor (extremidade 5' da } \\
\text { TU) }\end{array}$ & $\begin{array}{l}\text { Gene de 9a5c vizinho ao promotor } \\
\text { (extremidade } 5^{\prime} \text { da TU) }\end{array}$ & $\begin{array}{l}\text { Score normalizado do } \\
\text { alinhamento }\end{array}$ & Genes contidos na TU de Temecula1 & Genes contidos na TU de 9a5c \\
\hline $\begin{array}{l}\text { Probable taurine catabolism } \\
\text { dioxygenase [2514771303] }\end{array}$ & hypothetical protein [2514769159] & 0.7 & $\begin{array}{c}\text { Probable taurine catabolism dioxygenase } \\
\text { [2514771303]* Predicted permeases } \\
\text { [2514771304]* }\end{array}$ & $\begin{array}{c}\text { hypothetical protein }[2514769159]^{*} \text { Predicted } \\
\text { permeases }[2514769160]^{*} \text { hypothetical protein } \\
{[2514769161]}\end{array}$ \\
\hline $\begin{array}{l}\text { protein-(glutamine-N5) } \\
\text { methyltransferase, release factor- } \\
\text { specific [2514771302] }\end{array}$ & $\begin{array}{l}\text { protein-(glutamine-N5) } \\
\text { methyltransferase, release factor- } \\
\text { specific [2514769158] }\end{array}$ & 1.3 & $\begin{array}{l}\text { protein-(glutamine-N5) methyltransferase, release } \\
\text { factor-specific [2514771302]* }\end{array}$ & $\begin{array}{l}\text { protein-(glutamine-N5) methyltransferase, release } \\
\text { factor-specific [2514769158]* }\end{array}$ \\
\hline $\begin{array}{c}\text { succinyl-diaminopimelate } \\
\text { desuccinylase, proteobacterial } \\
\text { clade }[2514770580]\end{array}$ & $\begin{array}{c}\text { succinyl-diaminopimelate } \\
\text { desuccinylase, proteobacterial } \\
\text { clade }[2514767877]\end{array}$ & 1.4 & $\begin{array}{l}\text { succinyl-diaminopimelate desuccinylase, } \\
\text { proteobacterial clade [2514770580]* }\end{array}$ & $\begin{array}{l}\text { succinyl-diaminopimelate desuccinylase, proteobacterial } \\
\text { clade [2514767877]* }\end{array}$ \\
\hline $\begin{array}{l}\text { Multidrug resistance efflux pump } \\
\text { [2514771040] }\end{array}$ & $\begin{array}{l}\text { Multidrug resistance efflux pump } \\
\text { [2514768894] }\end{array}$ & 2.0 & Multidrug resistance efflux pump [2514771040]* & Multidrug resistance efflux pump [2514768894]* \\
\hline $\begin{array}{l}\text { ATPases involved in chromosome } \\
\text { partitioning }[2514772038]\end{array}$ & $\begin{array}{l}\text { ATPases involved in chromosome } \\
\text { partitioning [2514769955] }\end{array}$ & 2.1 & $\begin{array}{l}\text { ATPases involved in chromosome partitioning } \\
\qquad[2514772038]^{*}\end{array}$ & $\begin{array}{l}\text { ATPases involved in chromosome partitioning } \\
\text { [2514769955]* }\end{array}$ \\
\hline acetate--CoA ligase [2514771994] & acetate--CoA ligase [2514769916] & 2.2 & 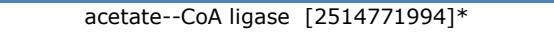 & acetate--CoA ligase [2514769916]* \\
\hline $\begin{array}{l}\text { Predicted membrane protein } \\
\text { [2514771993] }\end{array}$ & $\begin{array}{l}\text { Predicted membrane protein } \\
\text { [2514769915] }\end{array}$ & 2.3 & $\begin{array}{l}\text { Predicted membrane protein [2514771993]* } \\
\text { transporter, SSS family [2514771992]* }\end{array}$ & $\begin{array}{l}\text { Predicted membrane protein [2514769915]* } \\
\text { transporter, SSS family [2514769914]* }\end{array}$ \\
\hline $\begin{array}{l}\text { acetyl-CoA carboxylase, } \\
\text { carboxyl transferase, beta } \\
\text { subunit }[2514771257]\end{array}$ & $\begin{array}{l}\text { acetyl-CoA carboxylase, carboxyl } \\
\text { transferase, beta subunit } \\
{[2514769115]}\end{array}$ & 2.6 & $\begin{array}{c}\text { acetyl-CoA carboxylase, carboxyl transferase, beta } \\
\text { subunit }[2514771257]^{*} \text { phosphoglucosamine } \\
\text { mutase }[2514771258]^{*}\end{array}$ & $\begin{array}{c}\text { acetyl-CoA carboxylase, carboxyl transferase, beta } \\
\text { subunit }[2514769115]^{*} \text { phosphoglucosamine mutase } \\
{[2514769116]^{*}}\end{array}$ \\
\hline $\begin{array}{l}\text { tol-pal system beta propeller } \\
\text { repeat protein TolB [2514771500] }\end{array}$ & $\begin{array}{l}\text { tol-pal system beta propeller repeat } \\
\text { protein TolB }[2514769560]\end{array}$ & 2.6 & $\begin{array}{l}\text { tol-pal system beta propeller repeat protein TolB } \\
\qquad[2514771500]^{*}\end{array}$ & $\begin{array}{l}\text { tol-pal system beta propeller repeat protein TolB } \\
\qquad[2514769560]^{*}\end{array}$ \\
\hline $\begin{array}{l}\text { Predicted dithiol-disulfide } \\
\text { isomerase involved in polyketide } \\
\text { biosynthesis [2514771871] }\end{array}$ & $\begin{array}{l}\text { Predicted dithiol-disulfide isomerase } \\
\text { involved in polyketide biosynthesis } \\
\text { [2514769796] }\end{array}$ & 2.6 & $\begin{array}{l}\text { Predicted dithiol-disulfide isomerase involved in } \\
\text { polyketide biosynthesis [2514771871]* }\end{array}$ & $\begin{array}{l}\text { Predicted dithiol-disulfide isomerase involved in } \\
\text { polyketide biosynthesis [2514769796]* }\end{array}$ \\
\hline
\end{tabular}




\begin{tabular}{|c|c|c|c|c|}
\hline $\begin{array}{l}\text { pheromone shutdown-related } \\
\text { protein TraB [2514772175] }\end{array}$ & $\begin{array}{c}\text { pheromone shutdown-related protein } \\
\text { TraB [2514770079] }\end{array}$ & 2.7 & $\begin{array}{l}\text { pheromone shutdown-related protein TraB } \\
\text { [2514772175]* }\end{array}$ & $\begin{array}{l}\text { pheromone shutdown-related protein TraB } \\
\text { [2514770079]* }\end{array}$ \\
\hline $\begin{array}{l}\text { yjeF C-terminal region, } \\
\text { hydroxyethylthiazole kinase- } \\
\text { related/yjeF N-terminal region } \\
{[2514772688]}\end{array}$ & $\begin{array}{c}\text { yjeF C-terminal region, } \\
\text { hydroxyethylthiazole kinase- } \\
\text { related/yjeF N-terminal region } \\
{[2514768463]}\end{array}$ & 2.8 & $\begin{array}{l}\text { yjef C-terminal region, hydroxyethylthiazole kinase- } \\
\text { related/yjeF N-terminal region [2514772688]* } \\
\text { ATPase, YjeE family [2514772687]* }\end{array}$ & $\begin{array}{c}\text { yjeF C-terminal region, hydroxyethylthiazole kinase- } \\
\text { related/yjeF N-terminal region [2514768463** ATPase, } \\
\text { YjeE family [2514768464]* }\end{array}$ \\
\hline $\begin{array}{l}\text { exodeoxyribonuclease VII, large } \\
\text { subunit [2514772689] }\end{array}$ & $\begin{array}{l}\text { exodeoxyribonuclease VII, large } \\
\text { subunit [2514768462] }\end{array}$ & 2.8 & $\begin{array}{l}\text { exodeoxyribonuclease VII, large subunit } \\
\text { [2514772689]* }\end{array}$ & exodeoxyribonuclease VII, large subunit [2514768462]* \\
\hline $\begin{array}{l}\text { Uncharacterized protein conserved } \\
\text { in bacteria [2514770695] }\end{array}$ & $\begin{array}{l}\text { Uncharacterized protein conserved in } \\
\text { bacteria [2514767989] }\end{array}$ & 2.8 & $\begin{array}{l}\text { Uncharacterized protein conserved in bacteria } \\
\text { [2514770695]* transcription termination factor } \\
\text { NusA/transcription termination factor NusA, C- } \\
\text { terminal duplication [2514770696]* }\end{array}$ & $\begin{array}{l}\text { Uncharacterized protein conserved in bacteria } \\
\text { [2514767989 }]^{*} \text { transcription termination factor } \\
\text { NusA/transcription termination factor NusA, C-terminal } \\
\text { duplication [2514767990]* }\end{array}$ \\
\hline $\begin{array}{c}\text { Outer membrane receptor } \\
\text { proteins, mostly Fe transport } \\
{[2514771872]}\end{array}$ & $\begin{array}{c}\text { Outer membrane receptor } \\
\text { proteins, mostly Fe transport } \\
{[2514769797]}\end{array}$ & 3.0 & $\begin{array}{l}\text { Outer membrane receptor proteins, mostly Fe } \\
\text { transport [2514771872]* }\end{array}$ & $\begin{array}{l}\text { Outer membrane receptor proteins, mostly Fe transport } \\
\qquad[2514769797]^{*}\end{array}$ \\
\hline $\begin{array}{l}\text { N-acetyl-beta-hexosaminidase } \\
{[2514772604]}\end{array}$ & $\begin{array}{l}\mathrm{N} \text {-acetyl-beta-hexosaminidase } \\
{[2514768543]}\end{array}$ & 3.0 & N-acetyl-beta-hexosaminidase [2514772604]* & $\begin{array}{l}\text { N-acetyl-beta-hexosaminidase [2514768543]* Beta- } \\
\text { galactosidase/beta-glucuronidase [2514768542] }\end{array}$ \\
\hline $\begin{array}{l}\text { polyphosphate kinase } 1 \\
\text { [2514772766] }\end{array}$ & $\begin{array}{l}\text { polyphosphate kinase } 1 \\
\text { [2514770223] }\end{array}$ & 3.0 & polyphosphate kinase 1 [2514772766]* & polyphosphate kinase 1 [2514770223]* \\
\hline $\begin{array}{l}\text { hypothetical protein } \\
\text { [2514771768] }\end{array}$ & hypothetical protein [2514770139] & 3.1 & $\begin{array}{l}\text { hypothetical protein [2514771768]* Phage-related } \\
\text { lysozyme (muraminidase) [2514771767]* }\end{array}$ & $\begin{array}{l}\text { hypothetical protein [2514770139]* Phage-related } \\
\text { lysozyme (muraminidase) [2514770138]* }\end{array}$ \\
\hline $\begin{array}{l}\text { Type IV secretory pathway, Vir] } \\
\text { component [2514772690] }\end{array}$ & $\begin{array}{l}\text { Type IV secretory pathway, Vir] } \\
\text { component }[2514768461]\end{array}$ & 3.1 & $\begin{array}{l}\text { Type IV secretory pathway, Vir] component } \\
\text { [2514772690]* }\end{array}$ & $\begin{array}{l}\text { Type IV secretory pathway, Vir] component } \\
\text { [2514768461]* }\end{array}$ \\
\hline $\begin{array}{l}\text { Phosphopantetheinyl transferase } \\
\text { [2514771462] }\end{array}$ & $\begin{array}{l}\text { Phosphopantetheinyl transferase } \\
\text { [2514769599] }\end{array}$ & 3.2 & Phosphopantetheinyl transferase [2514771462]* & Phosphopantetheinyl transferase [2514769599]* \\
\hline $\begin{array}{l}\text { aspartate-semialdehyde } \\
\text { dehydrogenase (peptidoglycan } \\
\text { organisms) [2514771172] }\end{array}$ & $\begin{array}{l}\text { aspartate-semialdehyde } \\
\text { dehydrogenase (peptidoglycan } \\
\text { organisms) [2514769027] }\end{array}$ & 3.2 & $\begin{array}{c}\text { aspartate-semialdehyde dehydrogenase } \\
\text { (peptidoglycan organisms) [2514771172]* FimV N- } \\
\text { terminal domain [2514771173]* pseudouridylate } \\
\text { synthase I }[2514771174]^{*} \\
\text { Phosphoribosylanthranilate isomerase } \\
\text { [2514771175]* hypothetical protein }[2514771176]\end{array}$ & $\begin{array}{c}\text { aspartate-semialdehyde dehydrogenase (peptidoglycan } \\
\text { organisms) [2514769027]* FimV N-terminal domain } \\
{[2514769028]^{*} \text { pseudouridylate synthase I }} \\
\text { [2514769029]* Phosphoribosylanthranilate isomerase } \\
\text { [2514769030]* }\end{array}$ \\
\hline $\begin{array}{l}\text { Fructose-2,6-bisphosphatase } \\
\text { [2514771511] }\end{array}$ & $\begin{array}{l}\text { Fructose-2,6-bisphosphatase } \\
\text { [2514769549] }\end{array}$ & 3.2 & Fructose-2,6-bisphosphatase [2514771511]* & Fructose-2,6-bisphosphatase [2514769549]* \\
\hline $\begin{array}{l}\text { FOG: CheY-like receiver } \\
\text { [2514772787] }\end{array}$ & $\begin{array}{l}\text { FOG: CheY-like receiver } \\
\text { [2514770245] }\end{array}$ & 3.2 & FOG: CheY-like receiver [2514772787]* & FOG: CheY-like receiver [2514770245]* \\
\hline $\begin{array}{l}\text { phosphoribosylamine--glycine } \\
\text { ligase [2514771424] }\end{array}$ & $\begin{array}{l}\text { phosphoribosylamine--glycine ligase } \\
\text { [2514769638] }\end{array}$ & 3.3 & $\begin{array}{c}\text { phosphoribosylamine--glycine ligase } \\
{[2514771424]^{*} \text { hypothetical protein }[2514771423]}\end{array}$ & $\begin{array}{c}\text { phosphoribosylamine--glycine ligase [2514769638]* } \\
\text { hypothetical protein [2514769639]hypothetical }\end{array}$ \\
\hline
\end{tabular}




\begin{tabular}{|c|c|c|c|c|}
\hline & & & & membrane protein, TIGR01666 [2514769640] \\
\hline $\begin{array}{l}\text { ATPase related to the helicase } \\
\text { subunit of the Holliday junction } \\
\text { resolvase }[2514771244]\end{array}$ & $\begin{array}{l}\text { ATPase related to the helicase subunit } \\
\text { of the Holliday junction resolvase } \\
\text { [2514769101] }\end{array}$ & 3.3 & $\begin{array}{l}\text { ATPase related to the helicase subunit of the } \\
\text { Holliday junction resolvase [2514771244]* }\end{array}$ & $\begin{array}{l}\text { ATPase related to the helicase subunit of the Holliday } \\
\text { junction resolvase [2514769101]* }\end{array}$ \\
\hline PAS domain S-box [2514772599] & PAS domain S-box [2514768548] & 3.3 & PAS domain S-box [2514772599]* & PAS domain S-box [2514768548]* \\
\hline $\begin{array}{l}\text { dimethyladenosine transferase } \\
\text { [2514771881] }\end{array}$ & $\begin{array}{l}\text { dimethyladenosine transferase } \\
\text { [2514769806] }\end{array}$ & 3.4 & $\begin{array}{l}\text { dimethyladenosine transferase }[2514771881]^{*} \\
\text { Uncharacterized protein affecting Mg2+/Co2+ } \\
\text { transport [2514771882]* bis(5"-nucleosyl)- } \\
\text { tetraphosphatase (symmetrical) [2514771883] }\end{array}$ & $\begin{array}{l}\text { dimethyladenosine transferase }[2514769806]^{*} \\
\text { Uncharacterized protein affecting Mg2+/Co2+ transport } \\
{[2514769807]^{*} \text { bis(5"-nucleosyl)-tetraphosphatase }} \\
\text { (symmetrical) }[2514769808]\end{array}$ \\
\hline $\begin{array}{c}\text { Phosphate starvation-inducible } \\
\text { protein PhoH, predicted ATPase } \\
\text { [2514772539] }\end{array}$ & $\begin{array}{c}\text { Phosphate starvation-inducible protein } \\
\text { PhoH, predicted ATPase } \\
\text { [2514768612] }\end{array}$ & 3.4 & $\begin{array}{l}\text { Phosphate starvation-inducible protein } \mathrm{PhoH}, \\
\text { predicted ATPase [2514772539]* }\end{array}$ & $\begin{array}{l}\text { Phosphate starvation-inducible protein PhoH, predicted } \\
\text { ATPase }[2514768612]^{*}\end{array}$ \\
\hline Protease II [2514771268] & Protease II [2514769126] & 3.4 & $\begin{array}{c}\text { Protease II }[2514771268]^{*} \text { hypothetical protein } \\
{[2514771269]^{*} \text { diaminopimelate epimerase }} \\
{[2514771270]^{*} \text { Uncharacterized protein conserved }} \\
\text { in bacteria }[2514771271]^{*} \text { tyrosine recombinase } \\
\text { XerC }[2514771272]^{*}\end{array}$ & $\begin{array}{c}\text { Protease II }[2514769126]^{*} \text { hypothetical protein } \\
{[2514769127]^{*} \text { diaminopimelate epimerase }} \\
{[2514769128]^{*} \text { Uncharacterized protein conserved in }} \\
\text { bacteria }[2514769129]^{*} \text { tyrosine recombinase XerC } \\
{[2514769130]^{*}}\end{array}$ \\
\hline $\begin{array}{l}\text { acyl-CoA thioesterase II } \\
{[2514770835]}\end{array}$ & $\begin{array}{l}\text { acyl-CoA thioesterase II } \\
{[2514768718]}\end{array}$ & 3.4 & $\begin{array}{l}\text { acyl-CoA thioesterase II }[2514770835]^{*} \\
\text { hypothetical protein [2514770834]* }\end{array}$ & $\begin{array}{l}\text { acyl-CoA thioesterase II }[2514768718]^{*} \text { hypothetical } \\
\text { protein }[2514768717]^{*}\end{array}$ \\
\hline peroxiredoxin [2514771319] & peroxiredoxin [2514769176] & 3.5 & peroxiredoxin [2514771319]* & peroxiredoxin [2514769176]* \\
\hline $\begin{array}{l}\text { Predicted hydrolase of the } \\
\text { alpha/beta superfamily } \\
\text { [2514771689] }\end{array}$ & $\begin{array}{l}\text { Predicted hydrolase of the alpha/beta } \\
\text { superfamily [2514769488] }\end{array}$ & 3.5 & $\begin{array}{l}\text { Predicted hydrolase of the alpha/beta superfamily } \\
\text { [2514771689]* Predicted ATPase [2514771690]* }\end{array}$ & $\begin{array}{l}\text { Predicted hydrolase of the alpha/beta superfamily } \\
\text { [2514769488]* Predicted ATPase [2514769487]* }\end{array}$ \\
\hline $\begin{array}{l}\text { Lyzozyme M1 (1,4-beta- } \mathrm{N}- \\
\text { acetylmuramidase) [2514772115] }\end{array}$ & $\begin{array}{l}\text { Lyzozyme M1 (1,4-beta-N- } \\
\text { acetylmuramidase) [2514770031] }\end{array}$ & 3.5 & $\begin{array}{l}\text { Lyzozyme M1 (1,4-beta-N-acetylmuramidase) } \\
\text { [2514772115]* }\end{array}$ & $\begin{array}{l}\text { Lyzozyme M1 (1,4-beta-N-acetylmuramidase) } \\
{[2514770031]^{*}}\end{array}$ \\
\hline $\begin{array}{l}\text { ribosomal protein L11 } \\
\text { methyltransferase [2514771944] }\end{array}$ & $\begin{array}{l}\text { ribosomal protein L11 } \\
\text { methyltransferase }[2514769870]\end{array}$ & 3.5 & $\begin{array}{l}\text { ribosomal protein L11 methyltransferase } \\
\text { [2514771944]* }\end{array}$ & $\begin{array}{l}\text { ribosomal protein L11 methyltransferase } \\
\qquad[2514769870]^{*}\end{array}$ \\
\hline $\begin{array}{c}\text { branched-chain amino acid } \\
\text { aminotransferase, group II } \\
{[2514771401]}\end{array}$ & $\begin{array}{c}\text { branched-chain amino acid } \\
\text { aminotransferase, group II } \\
{[2514769658]}\end{array}$ & 3.5 & $\begin{array}{l}\text { branched-chain amino acid aminotransferase, group } \\
\text { II [2514771401]* }\end{array}$ & $\begin{array}{l}\text { branched-chain amino acid aminotransferase, group II } \\
\text { [2514769658]* }\end{array}$ \\
\hline $\begin{array}{l}\text { Predicted Rossmann fold } \\
\text { nucleotide-binding protein } \\
\text { [2514772351] }\end{array}$ & $\begin{array}{l}\text { Predicted Rossmann fold nucleotide- } \\
\text { binding protein [2514768198] }\end{array}$ & 3.5 & $\begin{array}{l}\text { Predicted Rossmann fold nucleotide-binding protein } \\
\text { [2514772351]* }\end{array}$ & $\begin{array}{l}\text { Predicted Rossmann fold nucleotide-binding protein } \\
\text { [2514768198]* }\end{array}$ \\
\hline $\begin{array}{l}\text { Entner-Doudoroff aldolase } \\
\qquad[2514770870]\end{array}$ & $\begin{array}{l}\text { Entner-Doudoroff aldolase } \\
\qquad \text { [2514768755] }\end{array}$ & 3.5 & Entner-Doudoroff aldolase [2514770870]* & Entner-Doudoroff aldolase [2514768755]* \\
\hline
\end{tabular}




\begin{tabular}{|c|c|c|c|c|}
\hline $\begin{array}{l}\text { hydro-lyases, Fe-S type, } \\
\text { tartrate/fumarate subfamily, alpha } \\
\text { region/hydro-lyases, Fe-S type, } \\
\text { tartrate/fumarate subfamily, beta } \\
\text { region [2514771563] }\end{array}$ & $\begin{array}{l}\text { hydro-lyases, Fe-S type, } \\
\text { tartrate/fumarate subfamily, alpha } \\
\text { region/hydro-lyases, Fe-S type, } \\
\text { tartrate/fumarate subfamily, beta } \\
\text { region [2514769513] }\end{array}$ & 3.5 & $\begin{array}{c}\text { hydro-lyases, Fe-S type, tartrate/fumarate } \\
\text { subfamily, alpha region/hydro-lyases, Fe-S type, } \\
\text { tartrate/fumarate subfamily, beta region } \\
{[2514771563]^{*}}\end{array}$ & $\begin{array}{l}\text { hydro-lyases, Fe-S type, tartrate/fumarate subfamily, } \\
\text { alpha region/hydro-lyases, } \mathrm{Fe}-\mathrm{S} \text { type, tartrate/fumarate } \\
\text { subfamily, beta region }[2514769513]^{*} \text { hypothetical } \\
\text { protein [2514769514] }\end{array}$ \\
\hline $\begin{array}{l}\text { methionine-S-sulfoxide reductase } \\
\text { [2514771458] }\end{array}$ & $\begin{array}{l}\text { methionine-S-sulfoxide reductase } \\
\text { [2514769604] }\end{array}$ & 3.5 & methionine-S-sulfoxide reductase [2514771458]* & methionine-S-sulfoxide reductase [2514769604]* \\
\hline $\begin{array}{l}\text { tRNA(Ile)-lysidine synthetase, } \mathrm{N}- \\
\text { terminal domain/tRNA(Ile)-lysidine } \\
\text { synthetase, C-terminal domain } \\
{[2514772234]}\end{array}$ & $\begin{array}{l}\text { tRNA(Ile)-lysidine synthetase, } \mathrm{N} \text { - } \\
\text { terminal domain/tRNA(Ile)-lysidine } \\
\text { synthetase, C-terminal domain } \\
\text { [2514768367] }\end{array}$ & 3.6 & $\begin{array}{c}\text { tRNA(Ile)-lysidine synthetase, } \mathrm{N} \text {-terminal } \\
\text { domain/tRNA(Ile)-lysidine synthetase, C-terminal } \\
\text { domain }[2514772234]^{*} \text { exodeoxyribonuclease VII, } \\
\text { small subunit }[2514772233]^{*}\end{array}$ & $\begin{array}{c}\text { tRNA(Ile)-lysidine synthetase, } \mathrm{N} \text {-terminal } \\
\text { domain/tRNA(Ile)-lysidine synthetase, C-terminal } \\
\text { domain }[2514768367]^{*} \text { exodeoxyribonuclease VII, } \\
\text { small subunit }[2514768368]^{*} \text { Geranylgeranyl } \\
\text { pyrophosphate synthase }[2514768369]\end{array}$ \\
\hline $\begin{array}{l}\text { Predicted acyltransferases } \\
\text { [2514770605] }\end{array}$ & $\begin{array}{l}\text { Predicted acyltransferases } \\
{[2514767900]}\end{array}$ & 3.6 & Predicted acyltransferases [2514770605]* & Predicted acyltransferases [2514767900]* \\
\hline $\begin{array}{l}\text { 30S ribosomal protein S13 } \\
\text { [2514770995] }\end{array}$ & $\begin{array}{l}\text { 30S ribosomal protein S13 } \\
\text { [2514768855] }\end{array}$ & 3.6 & $\begin{array}{c}\text { 30S ribosomal protein S13 [2514770995]* 30S } \\
\text { ribosomal protein S11 [2514770996]* ribosomal } \\
\text { protein S4, bacterial/organelle type }[2514770997]^{*}\end{array}$ & $\begin{array}{c}\text { 30S ribosomal protein S13 [2514768855]* 30S } \\
\text { ribosomal protein S11 [2514768856]* ribosomal protein } \\
\text { S4, bacterial/organelle type [2514768857]* }\end{array}$ \\
\hline $\begin{array}{l}\text { Putative multicopper oxidases } \\
\text { [2514772847] }\end{array}$ & $\begin{array}{l}\text { Putative multicopper oxidases } \\
\qquad[2514770300]\end{array}$ & 3.6 & Putative multicopper oxidases [2514772847]* & Putative multicopper oxidases [2514770300]* \\
\hline $\begin{array}{l}\text { Tfp pilus assembly protein, tip- } \\
\text { associated adhesin PilY1 } \\
\text { [2514771048] }\end{array}$ & $\begin{array}{l}\text { Tfp pilus assembly protein, tip- } \\
\text { associated adhesin PilY1 } \\
\text { [2514768903] }\end{array}$ & 3.7 & $\begin{array}{l}\text { Tfp pilus assembly protein, tip-associated adhesin } \\
\text { PilY1 [2514771048]* }\end{array}$ & $\begin{array}{l}\text { Tfp pilus assembly protein, tip-associated adhesin PilY1 } \\
\text { [2514768903]* }\end{array}$ \\
\hline $\begin{array}{l}\text { ribosome-binding factor A } \\
\text { [2514770698] }\end{array}$ & $\begin{array}{l}\text { ribosome-binding factor A } \\
\text { [2514767992] }\end{array}$ & 3.7 & ribosome-binding factor A [2514770698]* & ribosome-binding factor A [2514767992]* \\
\hline $\begin{array}{l}\text { Endoglucanase C-terminal } \\
\text { domain/subunit and related } \\
\text { proteins }[2514772643]\end{array}$ & $\begin{array}{c}\text { Endoglucanase C-terminal } \\
\text { domain/subunit and related proteins } \\
{[2514768512]}\end{array}$ & 3.7 & $\begin{array}{l}\text { Endoglucanase C-terminal domain/subunit and } \\
\text { related proteins [2514772643]* }\end{array}$ & $\begin{array}{l}\text { Endoglucanase C-terminal domain/subunit and related } \\
\text { proteins }[2514768512]^{*}\end{array}$ \\
\hline $\begin{array}{l}\text { Predicted metal-binding, possibly } \\
\text { nucleic acid-binding protein } \\
\text { [2514771701] }\end{array}$ & $\begin{array}{l}\text { Predicted metal-binding, possibly } \\
\text { nucleic acid-binding protein } \\
\text { [2514769476] }\end{array}$ & 3.7 & $\begin{array}{l}\text { Predicted metal-binding, possibly nucleic acid- } \\
\text { binding protein [2514771701]* }\end{array}$ & $\begin{array}{l}\text { Predicted metal-binding, possibly nucleic acid-binding } \\
\text { protein [2514769476]* }\end{array}$ \\
\hline $\begin{array}{l}\text { Flavodoxin reductases (ferredoxin- } \\
\text { NADPH reductases) family } 1 \\
\text { [2514771508] }\end{array}$ & $\begin{array}{l}\text { Flavodoxin reductases (ferredoxin- } \\
\text { NADPH reductases) family } 1 \\
\text { [2514769552] }\end{array}$ & 3.7 & $\begin{array}{l}\text { Flavodoxin reductases (ferredoxin-NADPH } \\
\text { reductases) family } 1 \text { [2514771508]* }\end{array}$ & $\begin{array}{l}\text { Flavodoxin reductases (ferredoxin-NADPH reductases) } \\
\text { family } 1 \text { [2514769552]* }\end{array}$ \\
\hline $\begin{array}{c}\text { mannose-1-phosphate } \\
\text { guanylyltransferase/mannose-6- } \\
\text { phosphate isomerase } \\
{[2514770719]}\end{array}$ & $\begin{array}{c}\text { mannose-1-phosphate } \\
\text { guanylyltransferase/mannose-6- } \\
\text { phosphate isomerase [2514768012] }\end{array}$ & 3.7 & $\begin{array}{c}\text { mannose-1-phosphate } \\
\text { guanylyltransferase/mannose-6-phosphate } \\
\text { isomerase }[2514770719]^{*}\end{array}$ & $\begin{array}{l}\text { mannose-1-phosphate guanyly|transferase/mannose-6- } \\
\text { phosphate isomerase }[2514768012]^{*}\end{array}$ \\
\hline
\end{tabular}




\begin{tabular}{|c|c|c|c|c|}
\hline $\begin{array}{l}\text { PAP2 (acid phosphatase) } \\
\text { superfamily protein } \\
\text { [2514772436] }\end{array}$ & $\begin{array}{l}\text { PAP2 (acid phosphatase) } \\
\text { superfamily protein } \\
\text { [2514768112] }\end{array}$ & 3.7 & $\begin{array}{l}\text { PAP2 (acid phosphatase) superfamily protein } \\
\text { [2514772436]* Predicted membrane-associated, } \\
\text { metal-dependent hydrolase [2514772435]* }\end{array}$ & $\begin{array}{c}\text { PAP2 (acid phosphatase) superfamily protein } \\
\text { [2514768112]* Predicted membrane-associated, metal- } \\
\text { dependent hydrolase }[2514768113]^{*}\end{array}$ \\
\hline glutamate 5-kinase [2514770817] & glutamate 5-kinase [2514768700] & 3.7 & glutamate 5-kinase [2514770817]* & glutamate 5-kinase [2514768700]* \\
\hline $\begin{array}{l}\text { DNA repair protein RecO } \\
\text { [2514771988] }\end{array}$ & $\begin{array}{l}\text { DNA repair protein RecO } \\
\text { [2514769912] }\end{array}$ & 3.7 & DNA repair protein RecO [2514771988]* & DNA repair protein RecO [2514769912]* \\
\hline $\begin{array}{l}\text { adenylosuccinate synthase } \\
{[2514772364]}\end{array}$ & $\begin{array}{c}\text { adenylosuccinate synthase } \\
{[2514768185]}\end{array}$ & 3.7 & adenylosuccinate synthase [2514772364]* & adenylosuccinate synthase $[2514768185]^{*}$ \\
\hline $\begin{array}{l}\text { Integral membrane protein } \\
\text { possibly involved in chromosome } \\
\text { condensation [2514771245] }\end{array}$ & $\begin{array}{l}\text { Integral membrane protein possibly } \\
\text { involved in chromosome condensation } \\
\text { [2514769102] }\end{array}$ & 3.7 & $\begin{array}{l}\text { Integral membrane protein possibly involved in } \\
\text { chromosome condensation [2514771245]* }\end{array}$ & $\begin{array}{l}\text { Integral membrane protein possibly involved in } \\
\text { chromosome condensation [2514769102]* hypothetical } \\
\text { protein [2514769103] }\end{array}$ \\
\hline $\begin{array}{l}\text { Amino acid transporters } \\
\text { [2514771950] }\end{array}$ & $\begin{array}{l}\text { Amino acid transporters } \\
\text { [2514769876] }\end{array}$ & 3.8 & $\begin{array}{l}\text { Amino acid transporters }[2514771950]^{*} \\
\text { methylthioribulose-1-phosphate dehydratase } \\
\text { [2514771951]* Uncharacterized conserved protein, } \\
\text { contains double-stranded beta-helix domain } \\
\text { [2514771952 }]^{*} \text { 2,3-diketo-5-methylthio-1- } \\
\text { phosphopentane phosphatase }[2514771953]^{*}\end{array}$ & $\begin{array}{c}\text { Amino acid transporters }[2514769876]^{*} \\
\text { methylthioribulose-1-phosphate dehydratase } \\
\text { [2514769877]* Uncharacterized conserved protein, } \\
\text { contains double-stranded beta-helix domain } \\
\text { [2514769878]* 2,3-diketo-5-methylthio-1- } \\
\text { phosphopentane phosphatase }[2514769879]^{*}\end{array}$ \\
\hline $\begin{array}{l}\text { NTP pyrophosphohydrolases } \\
\text { including oxidative damage repair } \\
\text { enzymes [2514771392] }\end{array}$ & $\begin{array}{l}\text { NTP pyrophosphohydrolases including } \\
\text { oxidative damage repair enzymes } \\
\text { [2514769667] }\end{array}$ & 3.8 & $\begin{array}{l}\text { NTP pyrophosphohydrolases including oxidative } \\
\text { damage repair enzymes [2514771392]* }\end{array}$ & $\begin{array}{l}\text { NTP pyrophosphohydrolases including oxidative damage } \\
\text { repair enzymes [2514769667]* }\end{array}$ \\
\hline $\begin{array}{l}\text { Response regulators consisting of a } \\
\text { CheY-like receiver domain and a } \\
\text { winged-helix DNA-binding domain } \\
\text { [2514772369] }\end{array}$ & $\begin{array}{l}\text { Response regulators consisting of a } \\
\text { CheY-like receiver domain and a } \\
\text { winged-helix DNA-binding domain } \\
\text { [2514768180] }\end{array}$ & 3.8 & $\begin{array}{l}\text { Response regulators consisting of a CheY-like } \\
\text { receiver domain and a winged-helix DNA-binding } \\
\text { domain [2514772369]* }\end{array}$ & $\begin{array}{l}\text { Response regulators consisting of a CheY-like receiver } \\
\text { domain and a winged-helix DNA-binding domain } \\
\text { [2514768180]* }\end{array}$ \\
\hline $\begin{array}{l}\text { dihydroorotate dehydrogenase, } \\
\text { subfamily } 2 \text { [2514772748] }\end{array}$ & $\begin{array}{l}\text { dihydroorotate dehydrogenase, } \\
\text { subfamily } 2 \text { [2514770206] }\end{array}$ & 3.8 & $\begin{array}{c}\text { dihydroorotate dehydrogenase, subfamily } 2 \\
\text { [2514772748]* UDP-N- } \\
\text { acetylenolpyruvoylglucosamine reductase } \\
\text { [2514772749]* Permeases of the drug/metabolite } \\
\text { transporter (DMT) superfamily [2514772750]* }\end{array}$ & $\begin{array}{c}\text { dihydroorotate dehydrogenase, subfamily } 2 \\
\text { [2514770206]* UDP-N-acetylenolpyruvoylglucosamine } \\
\text { reductase }[2514770207]^{*} \text { Permeases of the } \\
\text { drug/metabolite transporter (DMT) superfamily } \\
{[2514770208]^{*}}\end{array}$ \\
\hline $\begin{array}{l}\text { Raf kinase inhibitor-like protein, } \\
\text { YbhB/YbcL family [2514771900] }\end{array}$ & $\begin{array}{l}\text { Raf kinase inhibitor-like protein, } \\
\text { YbhB/YbcL family [2514769825] }\end{array}$ & 3.8 & $\begin{array}{c}\text { Raf kinase inhibitor-like protein, YbhB/YbcL family } \\
\text { [2514771900]* }\end{array}$ & $\begin{array}{l}\text { Raf kinase inhibitor-like protein, YbhB/YbcL family } \\
\text { [2514769825]* }\end{array}$ \\
\hline $\begin{array}{c}\text { glutaminyl-tRNA synthetase } \\
\text { [2514771145] }\end{array}$ & $\begin{array}{c}\text { glutaminyl-tRNA synthetase } \\
\text { [2514768999] }\end{array}$ & 3.8 & glutaminyl-tRNA synthetase [2514771145]* & glutaminyl-tRNA synthetase [2514768999]* \\
\hline $\begin{array}{l}\text { phenylalanyl-tRNA synthetase, } \\
\text { alpha subunit [2514772701] }\end{array}$ & $\begin{array}{l}\text { phenylalanyl-tRNA synthetase, alpha } \\
\text { subunit [2514768451] }\end{array}$ & 3.8 & $\begin{array}{l}\text { phenylalanyl-tRNA synthetase, alpha subunit } \\
\text { [2514772701]* }\end{array}$ & $\begin{array}{l}\text { phenylalanyl-tRNA synthetase, alpha subunit } \\
\text { [2514768451]* }\end{array}$ \\
\hline $\begin{array}{c}\text { peptidyl-tRNA hydrolase } \\
\text { [2514772819] }\end{array}$ & $\begin{array}{l}\text { peptidyl-tRNA hydrolase } \\
{[2514770275]}\end{array}$ & 3.8 & $\begin{array}{c}\text { peptidyl-tRNA hydrolase [2514772819]* GTP- } \\
\text { binding protein YChF [2514772818]* hypothetical }\end{array}$ & $\begin{array}{l}\text { peptidyl-tRNA hydrolase }[2514770275]^{*} \text { GTP-binding } \\
\text { protein YchF }[2514770274]^{*} \text { hypothetical protein }\end{array}$ \\
\hline
\end{tabular}




\begin{tabular}{|c|c|c|c|c|}
\hline & & & protein [2514772817]* & [2514770273]* \\
\hline $\begin{array}{l}\text { Protein-disulfide isomerase } \\
\text { [2514771230] }\end{array}$ & $\begin{array}{l}\text { Protein-disulfide isomerase } \\
\text { [2514769087] }\end{array}$ & 3.8 & $\begin{array}{c}\text { Protein-disulfide isomerase [2514771230]* Metal- } \\
\text { dependent hydrolase [2514771231]* }\end{array}$ & $\begin{array}{c}\text { Protein-disulfide isomerase [2514769087]* Metal- } \\
\text { dependent hydrolase [2514769088]* }\end{array}$ \\
\hline $\begin{array}{c}\text { DNA primase, catalytic core } \\
\text { [2514772387] }\end{array}$ & $\begin{array}{l}\text { DNA primase, catalytic core } \\
\text { [2514768162] }\end{array}$ & 3.8 & DNA primase, catalytic core $[2514772387]^{*}$ & DNA primase, catalytic core $[2514768162]^{*}$ \\
\hline $\begin{array}{c}\text { Restriction endonuclease } \\
{[2514771485]}\end{array}$ & $\begin{array}{c}\text { Restriction endonuclease } \\
{[2514769575]}\end{array}$ & 3.9 & Restriction endonuclease [2514771485]* & Restriction endonuclease [2514769575]* \\
\hline $\begin{array}{c}\text { lipoprotein signal peptidase } \\
\text { [2514772149] }\end{array}$ & $\begin{array}{c}\text { lipoprotein signal peptidase } \\
\text { [2514770053] }\end{array}$ & 3.9 & lipoprotein signal peptidase [2514772149]* & lipoprotein signal peptidase [2514770053]* \\
\hline $\begin{array}{l}\text { Zn-dependent protease with } \\
\text { chaperone function [2514772798] }\end{array}$ & $\begin{array}{l}\text { Zn-dependent protease with } \\
\text { chaperone function [2514770254] }\end{array}$ & 3.9 & $\begin{array}{l}\text { Zn-dependent protease with chaperone function } \\
\text { [2514772798]* }\end{array}$ & $\begin{array}{l}\text { Zn-dependent protease with chaperone function } \\
\text { [2514770254]* }\end{array}$ \\
\hline $\begin{array}{l}\text { Multiple antibiotic transporter } \\
\text { [2514772839] }\end{array}$ & $\begin{array}{l}\text { Multiple antibiotic transporter } \\
\text { [2514770294] }\end{array}$ & 3.9 & Multiple antibiotic transporter [2514772839]* & Multiple antibiotic transporter [2514770294]* \\
\hline K+ transporter $[2514771494]$ & K+ transporter $[2514769566]$ & 3.9 & K+ transporter [2514771494]* & K+ transporter $[2514769566]^{*}$ \\
\hline $\begin{array}{l}\text { Parvulin-like peptidyl-prolyl } \\
\text { isomerase [2514771021] }\end{array}$ & $\begin{array}{l}\text { Parvulin-like peptidyl-prolyl isomerase } \\
\text { [2514768876] }\end{array}$ & 3.9 & $\begin{array}{l}\text { Parvulin-like peptidyl-prolyl isomerase } \\
\text { [2514771021]* }\end{array}$ & Parvulin-like peptidyl-prolyl isomerase [2514768876 $]^{*}$ \\
\hline $\begin{array}{l}\text { Uncharacterized protein conserved } \\
\text { in bacteria [2514771000] }\end{array}$ & $\begin{array}{l}\text { Uncharacterized protein conserved in } \\
\text { bacteria }[2514768860]\end{array}$ & 3.9 & $\begin{array}{l}\text { Uncharacterized protein conserved in bacteria } \\
{[2514771000]^{*} \text { Mg chelatase-related protein }} \\
{[2514771001]^{*} \text { hypothetical protein }[2514771002]}\end{array}$ & $\begin{array}{l}\text { Uncharacterized protein conserved in bacteria } \\
{[2514768860]^{*} \text { Mg chelatase-related protein }} \\
\text { [2514768861]* }\end{array}$ \\
\hline $\begin{array}{l}\text { 3-deoxy-D-manno-octulosonate } \\
\text { cytidylyltransferase [2514772039] }\end{array}$ & $\begin{array}{l}\text { 3-deoxy-D-manno-octulosonate } \\
\text { cytidylyltransferase [2514769954] }\end{array}$ & 3.9 & $\begin{array}{c}\text { 3-deoxy-D-manno-octulosonate cytidylyltransferase } \\
\text { [2514772039]* Protein-tyrosine-phosphatase } \\
\text { [2514772040]* }\end{array}$ & $\begin{array}{c}\text { 3-deoxy-D-manno-octulosonate cytidylyltransferase } \\
\text { [2514769954]* Protein-tyrosine-phosphatase } \\
\text { [2514769953]* }\end{array}$ \\
\hline $\begin{array}{l}\text { c-type cytochrome biogenesis } \\
\text { protein CcmF [2514772197] }\end{array}$ & $\begin{array}{l}\text { c-type cytochrome biogenesis protein } \\
\text { CcmF [2514770095] }\end{array}$ & 4.0 & $\begin{array}{c}\text { c-type cytochrome biogenesis protein CcmF } \\
\text { [2514772197]* periplasmic protein thiol:disulfide } \\
\text { oxidoreductases, DsbE subfamily [2514772198]* } \\
\text { Uncharacterized protein involved in biosynthesis of } \\
\text { c-type cytochromes [2514772199]* Cytochrome c } \\
\text { biogenesis factor [2514772200]* }\end{array}$ & $\begin{array}{c}\text { c-type cytochrome biogenesis protein CcmF } \\
\text { [2514770095]* periplasmic protein thiol:disulfide } \\
\text { oxidoreductases, DsbE subfamily [2514770096]* } \\
\text { Uncharacterized protein involved in biosynthesis of c- } \\
\text { type cytochromes [2514770097]* Cytochrome c } \\
\text { biogenesis factor [2514770098]* }\end{array}$ \\
\hline $\begin{array}{c}\text { ribosomal protein S5, } \\
\text { bacterial/organelle type } \\
{[2514770991]}\end{array}$ & $\begin{array}{c}\text { ribosomal protein S5, } \\
\text { bacterial/organelle type } \\
{[2514768851]}\end{array}$ & 4.0 & $\begin{array}{c}\text { ribosomal protein S5, bacterial/organelle type } \\
{[2514770991]^{*} \text { ribosomal protein L30, }} \\
\text { bacterial/organelle [2514770992]* ribosomal } \\
\text { protein L15, bacterial/organelle [2514770993]* } \\
\text { preprotein translocase, SecY subunit } \\
\text { [2514770994]* }\end{array}$ & $\begin{array}{l}\text { ribosomal protein S5, bacterial/organelle type } \\
{[2514768851]^{*} \text { ribosomal protein L30, }} \\
\text { bacterial/organelle [2514768852]* ribosomal protein } \\
\text { L15, bacterial/organelle [2514768853]* preprotein } \\
\text { translocase, SecY subunit [2514768854]* }\end{array}$ \\
\hline $\begin{array}{l}\text { Phosphate-selective porin } \\
\text { [2514770789] }\end{array}$ & $\begin{array}{l}\text { Phosphate-selective porin } \\
\text { [2514768674] }\end{array}$ & 4.0 & Phosphate-selective porin [2514770789]* & Phosphate-selective porin [2514768674]* \\
\hline
\end{tabular}




\begin{tabular}{|c|c|c|c|c|}
\hline $\begin{array}{c}\text { citrate transporter, CitMHS family } \\
{[2514770780]}\end{array}$ & $\begin{array}{l}\text { citrate transporter, CitMHS family } \\
\text { [2514768072] }\end{array}$ & 4.0 & citrate transporter, CitMHS family [2514770780]* & citrate transporter, CitMHS family [2514768072]* \\
\hline $\begin{array}{l}\text { TrpR-related protein YerC/YecD } \\
\text { [2514771962] }\end{array}$ & $\begin{array}{l}\text { TrpR-related protein YerC/YecD } \\
\text { [2514769888] }\end{array}$ & 4.0 & $\begin{array}{l}\text { TrpR-related protein YerC/YecD [2514771962]* } \\
\text { ATP phosphoribosyltransferase [2514771961]* } \\
\text { histidinol dehydrogenase [2514771960]* histidinol- } \\
\text { phosphate aminotransferase [2514771959]* } \\
\text { histidinol-phosphatase [2514771958]* imidazole } \\
\text { glycerol phosphate synthase, glutamine } \\
\text { amidotransferase subunit [2514771957]* } \\
\text { phosphoribosylformimino-5-aminoimidazole } \\
\text { carboxamide ribotide isomerase [2514771956]* }\end{array}$ & $\begin{array}{c}\text { TrpR-related protein YerC/YecD [2514769888 * ATP } \\
\text { phosphoribosyltransferase [2514769887]* histidinol } \\
\text { dehydrogenase [2514769886]* histidinol-phosphate } \\
\text { aminotransferase [2514769885]* histidinol- } \\
\text { phosphatase }[2514769884]^{*} \text { imidazole glycerol } \\
\text { phosphate synthase, glutamine amidotransferase } \\
\text { subunit }[2514769883]^{*} \text { phosphoribosylformimino-5- } \\
\text { aminoimidazole carboxamide ribotide isomerase } \\
{[2514769882]^{*}}\end{array}$ \\
\hline $\begin{array}{l}\text { Amino acid transporters } \\
\text { [2514771949] }\end{array}$ & $\begin{array}{l}\text { Amino acid transporters } \\
\text { [2514769875] }\end{array}$ & 4.0 & Amino acid transporters [2514771949]* & Amino acid transporters [2514769875]* \\
\hline $\begin{array}{l}\text { thiamine biosynthesis protein ThiC } \\
\text { [2514771509] }\end{array}$ & $\begin{array}{l}\text { thiamine biosynthesis protein ThiC } \\
\text { [2514769551] }\end{array}$ & 4.0 & thiamine biosynthesis protein ThiC [2514771509]* & thiamine biosynthesis protein ThiC $[2514769551]^{*}$ \\
\hline $\begin{array}{c}\mathrm{Na}+/ \mathrm{H}+\text {-dicarboxylate symporters } \\
{[2514770790]}\end{array}$ & $\begin{array}{c}\mathrm{Na}+/ \mathrm{H}+\text {-dicarboxylate symporters } \\
{[2514768675]}\end{array}$ & 4.0 & $\mathrm{Na}+/ \mathrm{H}+$-dicarboxylate symporters [2514770790]* & $\mathrm{Na}+/ \mathrm{H}+$-dicarboxylate symporters $[2514768675]^{*}$ \\
\hline $\begin{array}{l}\text { 3-oxoacyl-(acyl-carrier-protein) } \\
\text { reductase }[2514772221]\end{array}$ & $\begin{array}{l}\text { 3-oxoacyl-(acyl-carrier-protein) } \\
\text { reductase }[2514768380]\end{array}$ & 4.0 & $\begin{array}{c}\text { 3-oxoacyl-(acyl-carrier-protein) reductase } \\
\text { [2514772221] }\end{array}$ & $\begin{array}{c}\text { 3-oxoacyl-(acyl-carrier-protein) reductase } \\
\text { [2514768380]* }\end{array}$ \\
\hline $\begin{array}{l}\text { Uncharacterized enzymes related } \\
\text { to aldose } 1 \text {-epimerase } \\
\text { [2514772005] }\end{array}$ & $\begin{array}{l}\text { Uncharacterized enzymes related to } \\
\text { aldose 1-epimerase [2514769929] }\end{array}$ & 4.0 & $\begin{array}{l}\text { Uncharacterized enzymes related to aldose } 1- \\
\text { epimerase [2514772005]* }\end{array}$ & $\begin{array}{l}\text { Uncharacterized enzymes related to aldose 1-epimerase } \\
\text { [2514769929]* }\end{array}$ \\
\hline $\begin{array}{l}\text { hypothetical protein } \\
\text { [2514771317] }\end{array}$ & hypothetical protein [2514769174] & 4.0 & $\begin{array}{l}\text { hypothetical protein [2514771317]* } \\
\text { Autotransporter adhesin [2514771318]* }\end{array}$ & $\begin{array}{l}\text { hypothetical protein [2514769174]* Autotransporter } \\
\text { adhesin [2514769175]* }\end{array}$ \\
\hline $\begin{array}{c}\text { Zn-dependent alcohol } \\
\text { dehydrogenases [2514770960] }\end{array}$ & $\begin{array}{c}\text { Zn-dependent alcohol } \\
\text { dehydrogenases [2514768820] }\end{array}$ & 4.0 & $\begin{array}{l}\text { Zn-dependent alcohol dehydrogenases } \\
\text { [2514770960]* Putative intracellular } \\
\text { protease/amidase [2514770961]* }\end{array}$ & $\begin{array}{l}\text { Zn-dependent alcohol dehydrogenases }[2514768820]^{*} \\
\text { Putative intracellular protease/amidase }[2514768821]^{*}\end{array}$ \\
\hline Glycosyltransferase [2514772097] & Glycosyltransferase [2514770011] & 4.0 & Glycosyltransferase [2514772097]* & $\begin{array}{c}\text { Glycosyltransferase }[2514770011]^{*} \text { hypothetical protein } \\
\text { [2514770010] Membrane protein involved in the export } \\
\text { of O-antigen and teichoic acid [2514770009] }\end{array}$ \\
\hline $\begin{array}{c}\text { Dipeptidyl } \\
\text { aminopeptidases/acylaminoacyl- } \\
\text { peptidases [2514772730] }\end{array}$ & $\begin{array}{c}\text { Dipeptidyl } \\
\text { aminopeptidases/acylaminoacyl- } \\
\text { peptidases [2514770188] }\end{array}$ & 4.0 & $\begin{array}{l}\text { Dipeptidyl aminopeptidases/acylaminoacyl- } \\
\text { peptidases [2514772730]* }\end{array}$ & $\begin{array}{l}\text { Dipeptidyl aminopeptidases/acylaminoacyl-peptidases } \\
\qquad[2514770188]^{*}\end{array}$ \\
\hline $\begin{array}{l}\text { Predicted nucleoside-diphosphate- } \\
\text { sugar epimerase [2514771679] }\end{array}$ & $\begin{array}{l}\text { Predicted nucleoside-diphosphate- } \\
\text { sugar epimerase }\end{array}$ & 4.1 & $\begin{array}{l}\text { Predicted nucleoside-diphosphate-sugar epimerase } \\
\text { [2514771679]* }\end{array}$ & $\begin{array}{c}\text { Predicted nucleoside-diphosphate-sugar epimerase } \\
\text { [2514769498]* Uncharacterized protein conserved in } \\
\text { bacteria }[2514769497] \text { hypothetical protein } \\
{[2514769496]}\end{array}$ \\
\hline
\end{tabular}




\begin{tabular}{|c|c|c|c|c|}
\hline $\begin{array}{l}\text { Short-chain alcohol dehydrogenase } \\
\text { of unknown specificity } \\
\text { [2514770608] }\end{array}$ & $\begin{array}{l}\text { Short-chain alcohol dehydrogenase of } \\
\text { unknown specificity [2514767903] }\end{array}$ & 4.1 & $\begin{array}{l}\text { Short-chain alcohol dehydrogenase of unknown } \\
\text { specificity [2514770608]* }\end{array}$ & $\begin{array}{l}\text { Short-chain alcohol dehydrogenase of unknown } \\
\text { specificity [2514767903]* }\end{array}$ \\
\hline $\begin{array}{l}\text { Pterin-4a-carbinolamine } \\
\text { dehydratase }[2514772780]\end{array}$ & $\begin{array}{l}\text { Pterin-4a-carbinolamine dehydratase } \\
\text { [2514770238] }\end{array}$ & 4.1 & $\begin{array}{c}\text { Pterin-4a-carbinolamine dehydratase } \\
{[2514772780]^{*} \text { TonB family C-terminal domain }} \\
{[2514772781]^{*}}\end{array}$ & $\begin{array}{l}\text { Pterin-4a-carbinolamine dehydratase }[2514770238]^{*} \\
\text { TonB family C-terminal domain }[2514770239]^{*}\end{array}$ \\
\hline $\begin{array}{l}\text { ribosome small subunit-dependent } \\
\text { GTPase A [2514772310] }\end{array}$ & $\begin{array}{l}\text { ribosome small subunit-dependent } \\
\text { GTPase A [2514768280] }\end{array}$ & 4.1 & $\begin{array}{l}\text { ribosome small subunit-dependent GTPase A } \\
\text { [2514772310]* }\end{array}$ & $\begin{array}{l}\text { ribosome small subunit-dependent GTPase A } \\
{[2514768280]^{*}}\end{array}$ \\
\hline $\begin{array}{l}\text { glucose/galactose transporter } \\
\qquad[2514771253]\end{array}$ & $\begin{array}{l}\text { glucose/galactose transporter } \\
\qquad[2514769111]\end{array}$ & 4.1 & $\begin{array}{c}\text { glucose/galactose transporter [2514771253]* } \\
\text { Transcriptional regulators }[2514771254]^{*} \text { Predicted } \\
\text { phosphosugar isomerases [2514771255]* N- } \\
\text { acetylglucosamine-6-phosphate deacetylase } \\
\text { [2514771256]* }\end{array}$ & $\begin{array}{c}\text { glucose/galactose transporter [2514769111]* } \\
\text { Transcriptional regulators }[2514769112]^{*} \text { Predicted } \\
\text { phosphosugar isomerases }[2514769113]^{*} \mathrm{~N}- \\
\text { acetylglucosamine-6-phosphate deacetylase } \\
\text { [2514769114]* }\end{array}$ \\
\hline $\begin{array}{c}\text { methionyl-tRNA } \\
\text { synthetase/methionyl-tRNA } \\
\text { synthetase C-terminal region/beta } \\
\text { chain }[2514772315]\end{array}$ & $\begin{array}{c}\text { methionyl-tRNA } \\
\text { synthetase/methionyl-tRNA } \\
\text { synthetase C-terminal region/beta } \\
\text { chain }[2514768275]\end{array}$ & 4.1 & $\begin{array}{l}\text { methionyl-tRNA synthetase/methionyl-tRNA } \\
\text { synthetase C-terminal region/beta chain } \\
\text { [2514772315]* }\end{array}$ & $\begin{array}{l}\text { methionyl-tRNA synthetase/methionyl-tRNA synthetase } \\
\text { C-terminal region/beta chain }[2514768275]^{*}\end{array}$ \\
\hline $\begin{array}{l}\text { 5,10-methenyltetrahydrofolate } \\
\text { synthetase [2514771386] }\end{array}$ & $\begin{array}{l}\text { 5,10-methenyltetrahydrofolate } \\
\text { synthetase [2514769673] }\end{array}$ & 4.1 & $\begin{array}{c}\text { 5,10-methenyltetrahydrofolate synthetase } \\
{[2514771386]^{*} \text { Uncharacterized conserved protein }} \\
{[2514771385]^{*} \text { ribose 5-phosphate isomerase }} \\
{[2514771384]}\end{array}$ & $\begin{array}{c}\text { 5,10-methenyltetrahydrofolate synthetase } \\
\text { [2514769673]* Uncharacterized conserved protein } \\
\text { [2514769674]* }\end{array}$ \\
\hline $\begin{array}{c}\text { glucose-1-phosphate } \\
\text { thymidylyltransferase, short form } \\
{[2514770716]}\end{array}$ & $\begin{array}{c}\text { glucose-1-phosphate } \\
\text { thymidylyltransferase, short form } \\
\text { [2514768009] }\end{array}$ & 4.1 & $\begin{array}{l}\text { glucose-1-phosphate thymidylyltransferase, short } \\
\text { form [2514770716]* dTDP-4-dehydrorhamnose } \\
\text { 3,5-epimerase [2514770717]* dTDP-4- } \\
\text { dehydrorhamnose reductase [2514770718]* }\end{array}$ & $\begin{array}{c}\text { glucose-1-phosphate thymidylyltransferase, short form } \\
\text { [2514768009]* dTDP-4-dehydrorhamnose } 3,5 \text { - } \\
\text { epimerase }[2514768010]^{*} \text { dTDP-4-dehydrorhamnose } \\
\text { reductase }[2514768011]^{*}\end{array}$ \\
\hline Exonuclease I [2514771377] & Exonuclease I [2514769680] & 4.1 & $\begin{array}{l}\text { Exonuclease I }[2514771377]^{*} \text { TIGR02453 family } \\
\text { protein }[2514771376]^{*}\end{array}$ & $\begin{array}{l}\text { Exonuclease I }[2514769680]^{*} \text { TIGR02453 family } \\
\text { protein }[2514769681]^{*}\end{array}$ \\
\hline $\begin{array}{l}\text { periplasmic chaperone LolA } \\
\qquad[2514771243]\end{array}$ & $\begin{array}{l}\text { Outer membrane lipoprotein-sorting } \\
\text { protein [2514769100] }\end{array}$ & 4.1 & periplasmic chaperone LolA [2514771243]* & $\begin{array}{l}\text { Outer membrane lipoprotein-sorting protein } \\
\qquad[2514769100]^{*}\end{array}$ \\
\hline $\begin{array}{l}\text { uroporphyrinogen decarboxylase } \\
{[2514771141]}\end{array}$ & $\begin{array}{l}\text { uroporphyrinogen decarboxylase } \\
\text { [2514768995] }\end{array}$ & 4.1 & uroporphyrinogen decarboxylase [2514771141]* & uroporphyrinogen decarboxylase [2514768995]* \\
\hline $\begin{array}{l}\text { hypothetical protein } \\
\text { [2514772506] }\end{array}$ & hypothetical protein [2514768650] & 4.1 & $\begin{array}{l}\text { hypothetical protein [2514772506]* transcriptional } \\
\text { regulator NrdR [2514772505]* }\end{array}$ & $\begin{array}{l}\text { hypothetical protein }[2514768650]^{*} \text { transcriptional } \\
\text { regulator NrdR [2514768651]* }\end{array}$ \\
\hline $\begin{array}{c}\text { Acetylornithine } \\
\text { deacetylase/Succinyl- } \\
\text { diaminopimelate desuccinylase and } \\
\text { related deacylases [2514770813] }\end{array}$ & $\begin{array}{l}\text { Acetylornithine deacetylase/Succinyl- } \\
\text { diaminopimelate desuccinylase and } \\
\text { related deacylases [2514768696] }\end{array}$ & 4.1 & $\begin{array}{l}\text { Acetylornithine deacetylase/Succinyl- } \\
\text { diaminopimelate desuccinylase and related } \\
\text { deacylases [2514770813]* }\end{array}$ & $\begin{array}{l}\text { Acetylornithine deacetylase/Succinyl-diaminopimelate } \\
\text { desuccinylase and related deacylases [2514768696]* }\end{array}$ \\
\hline
\end{tabular}




\begin{tabular}{|c|c|c|c|c|}
\hline $\begin{array}{l}\text { general secretion pathway protein } \\
\text { G [2514771308] }\end{array}$ & $\begin{array}{l}\text { general secretion pathway protein } \mathrm{G} \\
{[2514769165]}\end{array}$ & 4.1 & 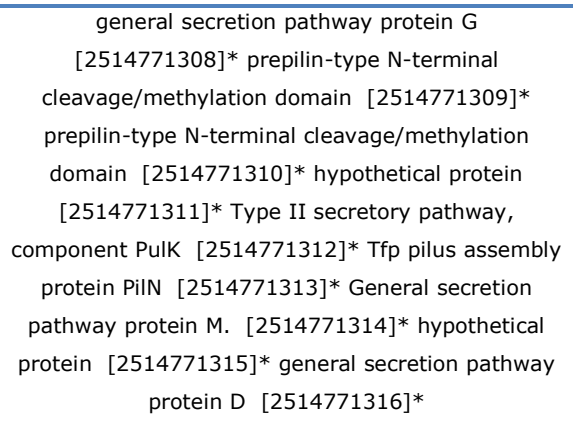 & $\begin{array}{c}\text { general secretion pathway protein G }[2514769165]^{*} \\
\text { prepilin-type N-terminal cleavage/methylation domain } \\
\text { [2514769166]* prepilin-type N-terminal } \\
\text { cleavage/methylation domain [2514769167]* } \\
\text { hypothetical protein [2514769168]* Type II secretory } \\
\text { pathway, component PulK [2514769169]* Tfp pilus } \\
\text { assembly protein PilN [2514769170]* General secretion } \\
\text { pathway protein M. [2514769171]* hypothetical protein } \\
{[2514769172]^{*} \text { general secretion pathway protein D }} \\
\text { [2514769173]* }\end{array}$ \\
\hline $\begin{array}{l}\text { Phage baseplate assembly protein } \\
\qquad \text { W [2514770896] }\end{array}$ & $\begin{array}{l}\text { Phage baseplate assembly protein W } \\
\text { [2514768434] }\end{array}$ & 4.1 & $\begin{array}{l}\text { Phage baseplate assembly protein } \mathrm{W} \text { [2514770896] } \\
\text { * Phage-related baseplate assembly protein } \\
\text { [2514770895]* phage tail protein, P2 protein I } \\
\text { family [2514770894] * hypothetical protein } \\
\text { [2514770893]Phage protein D [2514770892] }\end{array}$ & $\begin{array}{c}\text { Phage baseplate assembly protein W }[2514768434] * \\
\text { Phage-related baseplate assembly protein } \\
\text { [2514768435] * phage tail protein, P2 protein I family } \\
\text { [2514768436] * hypothetical protein } \\
\text { [2514768437]hypothetical protein [2514768438] }\end{array}$ \\
\hline $\begin{array}{l}\text { Arabinose efflux permease } \\
\text { [2514770728] }\end{array}$ & $\begin{array}{c}\text { Arabinose efflux permease } \\
{[2514768020]}\end{array}$ & 4.1 & Arabinose efflux permease $[2514770728]^{*}$ & Arabinose efflux permease [2514768020]* \\
\hline $\begin{array}{c}\text { FeS assembly ATPase SufC } \\
{[2514771264]}\end{array}$ & $\begin{array}{c}\text { FeS assembly ATPase SufC } \\
\text { [2514769122] }\end{array}$ & 4.1 & $\begin{array}{c}\text { FeS assembly ATPase SufC }[2514771264]^{*} \text { FeS } \\
\text { assembly protein SufD }[2514771263]^{*} \text { cysteine } \\
\text { desulfurases, SufSfamily }[2514771262]^{*}\end{array}$ & $\begin{array}{l}\text { FeS assembly ATPase SufC [2514769122]* FeS } \\
\text { assembly protein SufD [2514769121]* cysteine } \\
\text { desulfurases, SufSfamily [2514769120]* }\end{array}$ \\
\hline $\begin{array}{l}\text { Dehydrogenases with different } \\
\text { specificities (related to short-chain } \\
\text { alcohol dehydrogenases) } \\
\text { [2514772004] }\end{array}$ & $\begin{array}{l}\text { Dehydrogenases with different } \\
\text { specificities (related to short-chain } \\
\text { alcohol dehydrogenases) } \\
\text { [2514769928] }\end{array}$ & 4.1 & $\begin{array}{l}\text { Dehydrogenases with different specificities (related } \\
\text { to short-chain alcohol dehydrogenases) } \\
\text { [2514772004]* }\end{array}$ & $\begin{array}{l}\text { Dehydrogenases with different specificities (related to } \\
\text { short-chain alcohol dehydrogenases) [2514769928]* }\end{array}$ \\
\hline
\end{tabular}


Anexo 2. Promotores entre as cepas $9 a 5 \mathrm{c}$ e J1a12 com diferenças significativas (críticos). Genes com asteriscos (*) indicam genes compartilhados pelas TUs cujos promotores foram comparados. Os genes são descritos por suas funções seguidas pelos seus identificadores entre chaves. As informações foram extraídas da plataforma IMG-ER do JGI, utilizada para padronizar a anotação dos genomas. TUs em negrito (duas primeiras colunas) indicam promotores para os quais foram detectadas diferenças consideradas relevantes, relacionadas a elementos cis-regulatórios.

\begin{tabular}{|c|c|c|c|c|}
\hline $\begin{array}{c}\text { Gene de J1a12 vizinho ao } \\
\text { promotor (extremidade } 5^{\prime} \text { da } \\
\text { TU) }\end{array}$ & $\begin{array}{l}\text { Gene de 9a5c vizinho ao promotor } \\
\text { (extremidade 5' da TU) }\end{array}$ & $\begin{array}{l}\text { Score normalizado do } \\
\text { alinhamento }\end{array}$ & Genes contidos na TU de J1a12 & Genes contidos na TU de 9a5c \\
\hline $\begin{array}{l}\text { Predicted membrane } \\
\text { protein/domain [2510341779] }\end{array}$ & $\begin{array}{l}\text { Predicted membrane protein/domain } \\
{[2514767898]}\end{array}$ & 0.9 & $\begin{array}{l}\text { Predicted membrane protein/domain } \\
{[2510341779]^{*}}\end{array}$ & Predicted membrane protein/domain [2514767898]* \\
\hline $\begin{array}{l}\text { Predicted transcriptional } \\
\text { regulator [2510343673] }\end{array}$ & $\begin{array}{l}\text { Predicted transcriptional } \\
\text { regulator }[2514768406]\end{array}$ & 1.0 & Predicted transcriptional regulator [2510343673]* & Predicted transcriptional regulator [2514768406]* \\
\hline $\begin{array}{l}\text { Predicted transcriptional regulator } \\
{[2510342119]}\end{array}$ & $\begin{array}{l}\text { Predicted transcriptional regulator } \\
{[2514768406]}\end{array}$ & 1.0 & Predicted transcriptional regulator [2510342119]* & Predicted transcriptional regulator $[2514768406]^{*}$ \\
\hline $\begin{array}{c}\text { tRNA } \\
\text { nucleotidyltransferase/poly(A) } \\
\text { polymerase [2510342749] }\end{array}$ & $\begin{array}{l}\text { tRNA nucleotidyltransferase/poly(A) } \\
\text { polymerase }[2514769018]\end{array}$ & 3.2 & $\begin{array}{l}\text { tRNA nucleotidyltransferase/poly(A) polymerase } \\
{[2510342749]^{*}}\end{array}$ & $\begin{array}{l}\text { tRNA nucleotidyltransferase/poly(A) polymerase } \\
{[2514769018]^{*}}\end{array}$ \\
\hline $\begin{array}{l}\text { adenylosuccinate lyase } \\
{[2510343359]}\end{array}$ & $\begin{array}{l}\text { adenylosuccinate lyase } \\
{[2514769196]}\end{array}$ & 3.3 & adenylosuccinate lyase [2510343359]* & adenylosuccinate lyase [2514769196]* \\
\hline $\begin{array}{l}\text { acetoacetyl-CoA reductase } \\
{[2510341960]}\end{array}$ & $\begin{array}{l}\text { acetoacetyl-CoA reductase } \\
{[2514768071]}\end{array}$ & 3.7 & acetoacetyl-CoA reductase $[2510341960]^{*}$ & acetoacetyl-CoA reductase $[2514768071]^{*}$ \\
\hline $\begin{array}{l}\text { Dehydrogenases with different } \\
\text { specificities (related to short-chain } \\
\text { alcohol dehydrogenases) } \\
{[2510344426]}\end{array}$ & $\begin{array}{l}\text { Dehydrogenases with different } \\
\text { specificities (related to short-chain } \\
\text { alcohol dehydrogenases) } \\
\text { [2514770334] }\end{array}$ & 3.7 & $\begin{array}{l}\text { Dehydrogenases with different specificities (related } \\
\text { to short-chain alcohol dehydrogenases) } \\
\text { [2510344426]* }\end{array}$ & $\begin{array}{l}\text { Dehydrogenases with different specificities (related to } \\
\text { short-chain alcohol dehydrogenases) [2514770334]* }\end{array}$ \\
\hline $\begin{array}{l}\text { Prophage antirepressor } \\
\text { [2510344249] }\end{array}$ & $\begin{array}{l}\text { Prophage antirepressor } \\
{[2514768394]}\end{array}$ & 3.9 & $\begin{array}{c}\text { Prophage antirepressor [2510344249]* } \\
\text { hypothetical protein [2510344250]VRR-NUC } \\
\text { domain. }[2510344251] *\end{array}$ & $\begin{array}{c}\text { Prophage antirepressor [25147683944* DNA } \\
\text { polymerase I - } 3^{\prime \prime-5 " ~ e x o n u c l e a s e ~ a n d ~ p o l y m e r a s e ~} \\
\text { domains [2514768393]VRR-NUC domain. } \\
\text { [2514768392] * }\end{array}$ \\
\hline $\begin{array}{l}\text { Phosphatidylserine/phosphatidylgly } \\
\text { cerophosphate/cardiolipin } \\
\text { synthases and related enzymes } \\
\text { [2510342895] }\end{array}$ & $\begin{array}{l}\text { Phosphatidylserine/phosphatidylglycer } \\
\text { ophosphate/cardiolipin synthases and } \\
\text { related enzymes [2514768888] }\end{array}$ & 4.1 & $\begin{array}{l}\text { Phosphatidylserine/phosphatidylglycerophosphate/c } \\
\text { ardiolipin synthases and related enzymes } \\
\text { [2510342895]* }\end{array}$ & $\begin{array}{l}\text { Phosphatidylserine/phosphatidylglycerophosphate/cardi } \\
\text { olipin synthases and related enzymes [2514768888]* }\end{array}$ \\
\hline $\begin{array}{l}\text { Predicted GTPase } \\
{[2510342493]}\end{array}$ & $\begin{array}{c}\text { Bacteriocin class II with double- } \\
\text { glycine leader peptide. } \\
\text { [2514769337] }\end{array}$ & 4.2 & $\begin{array}{c}\text { Predicted GTPase [2510342493]* hypothetical } \\
\text { protein [2510342494]* }\end{array}$ & $\begin{array}{l}\text { Bacteriocin class II with double-glycine leader peptide. } \\
\text { [2514769337]* hypothetical protein [2514769338]* }\end{array}$ \\
\hline $\begin{array}{l}\text { hypothetical protein } \\
{[2510342584]}\end{array}$ & hypothetical protein [2514769295] & 4.2 & $\begin{array}{l}\text { hypothetical protein [2510342584]* Protein } \\
\text { involved in cell division [2510342585]* }\end{array}$ & $\begin{array}{l}\text { hypothetical protein [2514769295]* Protein involved in } \\
\text { cell division [2514769296]* }\end{array}$ \\
\hline $\begin{array}{l}\text { hypothetical protein } \\
{[2510342583]}\end{array}$ & hypothetical protein [2514769294] & 4.2 & $\begin{array}{c}\text { hypothetical protein }[2510342583]^{*} \text { hypothetical } \\
\text { protein }[2510342582]^{*} \text { hypothetical protein } \\
{[2510342581]^{*} \text { hypothetical protein }} \\
{[2510342580] \text { hypothetical protein }} \\
{[2510342579] \text { hypothetical protein }[2510342578]^{*}} \\
\text { Uncharacterized conserved protein }[2510342577] * \\
\text { phage recombination protein Bet }[2510342576]^{*} \\
\text { putative phage-type endonuclease }[2510342575]^{*} \\
\text { Prophage antirepressor }[2510342574]\end{array}$ & $\begin{array}{c}\text { hypothetical protein [2514769294]* hypothetical } \\
\text { protein [2514769293]* hypothetical protein } \\
{[2514769292]^{*} \text { hypothetical protein }[2514769291]} \\
\text { hypothetical protein [251476920]hypothetical protein } \\
{[2514769289]^{*} \text { Uncharacterized conserved protein }} \\
{[2514769288]^{*} \text { phage recombination protein Bet }} \\
{[2514769287]^{*} \text { putative phage-type endonuclease }} \\
{[2514769286]^{*} \text { UDP-3-O-[3-hydroxymyristoyl] }} \\
\text { glucosamine } \mathrm{N} \text {-acyltransferase }[2514769285]\end{array}$ \\
\hline $\begin{array}{l}\text { Predicted transcriptional regulator } \\
{[2510342586]}\end{array}$ & $\begin{array}{l}\text { Predicted transcriptional regulator } \\
{[2514769297]}\end{array}$ & 4.2 & Predicted transcriptional regulator $[2510342586]^{*}$ & Predicted transcriptional regulator [2514769297]* \\
\hline Protease II [2510342636] & Protease II [2514769126] & 4.3 & Protease II [2510342636]* & $\begin{array}{c}\text { Protease II [2514769126]* hypothetical protein } \\
{[2514769127] \text { diaminopimelate epimerase }} \\
{[2514769128] \text { Uncharacterized protein conserved in }} \\
\text { bacteria [2514769129] tyrosine recombinase XerC }\end{array}$ \\
\hline
\end{tabular}




\begin{tabular}{|c|c|c|c|c|}
\hline & & & & [2514769130] \\
\hline $\begin{array}{l}\text { Bacteriophage tail assembly } \\
\text { protein }[2510342131]\end{array}$ & $\begin{array}{l}\text { Bacteriophage tail assembly protein } \\
\text { [2514768238] }\end{array}$ & 4.4 & $\begin{array}{c}\text { Bacteriophage tail assembly protein } \\
\text { [2510342131]* hypothetical protein [2510342132] } \\
\text { phage portal protein, lambda family } \\
\text { [2510342133]* Protease subunit of ATP-dependent } \\
\text { Clp proteases [2510342134]* }\end{array}$ & $\begin{array}{c}\text { Bacteriophage tail assembly protein [2514768238] * } \\
\text { hypothetical protein [2514768239]phage portal } \\
\text { protein, lambda family [2514768240] * Protease } \\
\text { subunit of ATP-dependent Clp proteases [2514768241] } \\
*\end{array}$ \\
\hline $\begin{array}{c}\text { Nitrogen regulatory protein PII } \\
{[2510343588]}\end{array}$ & $\begin{array}{c}\text { Nitrogen regulatory protein PII } \\
{[2514769502]}\end{array}$ & 4.4 & $\begin{array}{c}\text { Nitrogen regulatory protein PII [2510343588 } \\
\text { ammonium transporter [2510343589]* }\end{array}$ & $\begin{array}{l}\text { Nitrogen regulatory protein PII [2514769502]* } \\
\text { ammonium transporter [2514769503]* }\end{array}$ \\
\hline $\begin{array}{l}\text { Bacteriophage tail assembly } \\
\text { protein }[2510343685]\end{array}$ & $\begin{array}{l}\text { Bacteriophage tail assembly protein } \\
\text { [2514768238] }\end{array}$ & 4.4 & $\begin{array}{c}\text { Bacteriophage tail assembly protein } \\
\text { [2510343685]* hypothetical protein [2510343686] } \\
\text { phage portal protein, lambda family } \\
\text { [2510343687]* Protease subunit of ATP-dependent } \\
\text { Clp proteases [2510343688]* }\end{array}$ & $\begin{array}{c}\text { Bacteriophage tail assembly protein [2514768238]* } \\
\text { hypothetical protein [2514768239]phage portal } \\
\text { protein, lambda family [2514768240]* Protease } \\
\text { subunit of ATP-dependent Clp proteases } \\
{[2514768241]^{*}}\end{array}$ \\
\hline $\begin{array}{l}\text { Uncharacterized conserved protein } \\
{[2510343018]}\end{array}$ & $\begin{array}{l}\text { Uncharacterized conserved protein } \\
{[2514768767]}\end{array}$ & 4.4 & $\begin{array}{l}\text { Uncharacterized conserved protein [2510343018]* } \\
\text { hypothetical protein [2510343017]* lipoprotein } \\
\text { releasing system, transmembrane protein, LolC/E } \\
\text { family [2510343016]* lipoprotein releasing } \\
\text { system, ATP-binding protein [2510343015] }\end{array}$ & $\begin{array}{c}\text { Uncharacterized conserved protein [2514768767]* } \\
\text { hypothetical protein [2514768768]* lipoprotein } \\
\text { releasing system, transmembrane protein, LolC/E } \\
\text { family [2514768769]* lipoprotein releasing system, } \\
\text { ATP-binding protein [2514768770] }\end{array}$ \\
\hline $\begin{array}{c}\text { UDP-3-O-[3-hydroxymyristoyl] } \\
\text { glucosamine N-acyltransferase } \\
{[2510342693]}\end{array}$ & $\begin{array}{c}\text { UDP-3-O-[3-hydroxymyristoyl] } \\
\text { glucosamine N-acyltransferase } \\
{[2514769072]}\end{array}$ & 4.4 & $\begin{array}{l}\text { UDP-3-O-[3-hydroxymyristoyl] glucosamine N- } \\
\text { acyltransferase [2510342693* hypothetical } \\
\text { protein }[2510342692]\end{array}$ & $\begin{array}{l}\text { UDP-3-O-[3-hydroxymyristoyl] glucosamine N- } \\
\text { acyltransferase [2514769072** hypothetical protein } \\
{[2514769073] \text { hypothetical protein }[2514769074]}\end{array}$ \\
\hline $\begin{array}{l}\text { succinyl-COA synthetase, beta } \\
\text { subunit }[2510344273]\end{array}$ & $\begin{array}{c}\text { succinyl-CoA synthetase, beta subunit } \\
{[2514770184]}\end{array}$ & 4.4 & $\begin{array}{c}\text { succinyl-CoA synthetase, beta subunit } \\
{[2510344273]^{*} \text { succinyl-CoA synthetase, alpha }} \\
\text { subunit }[2510344274]^{*}\end{array}$ & $\begin{array}{l}\text { succinyl-CoA synthetase, beta subunit }[2514770184]^{*} \\
\text { succinyl-CoA synthetase, alpha subunit }[2514770185]^{*}\end{array}$ \\
\hline $\begin{array}{l}\text { putative hydrolase, CocE/NonD } \\
\text { family [2510343059] }\end{array}$ & $\begin{array}{l}\text { putative hydrolase, CocE/NonD family } \\
{[2514768725]}\end{array}$ & 4.4 & $\begin{array}{c}\text { putative hydrolase, CocE/NonD family } \\
{[2510343059]^{*}}\end{array}$ & putative hydrolase, CocE/NonD family [2514768725]* \\
\hline $\begin{array}{c}\text { mannose-1-phosphate } \\
\text { guanylyltransferase/mannose-6- } \\
\text { phosphate isomerase } \\
{[2510341896]}\end{array}$ & $\begin{array}{c}\text { mannose-1-phosphate } \\
\text { guanylyltransferase/mannose-6- } \\
\text { phosphate isomerase [2514768012] }\end{array}$ & 4.4 & $\begin{array}{c}\text { mannose-1-phosphate } \\
\text { guanylyltransferase/mannose-6-phosphate } \\
\text { isomerase }[2510341896]^{*}\end{array}$ & $\begin{array}{c}\text { mannose-1-phosphate guanylyltransferase/mannose-6- } \\
\text { phosphate isomerase }[2514768012]^{*}\end{array}$ \\
\hline $\begin{array}{c}\text { Dipeptidyl } \\
\text { aminopeptidases/acylaminoacyl- } \\
\text { peptidases [2510344277] }\end{array}$ & $\begin{array}{c}\text { Dipeptidyl } \\
\text { aminopeptidases/acylaminoacyl- } \\
\text { peptidases [2514770188] }\end{array}$ & 4.4 & $\begin{array}{l}\text { Dipeptidyl aminopeptidases/acylaminoacyl- } \\
\text { peptidases [2510344277]* }\end{array}$ & $\begin{array}{c}\text { Dipeptidyl aminopeptidases/acylaminoacyl-peptidases } \\
{[2514770188]^{*}}\end{array}$ \\
\hline $\begin{array}{l}\text { DNA mismatch repair protein MutL } \\
{[2510344175]}\end{array}$ & $\begin{array}{l}\text { DNA mismatch repair protein MutL } \\
{[2514768466]}\end{array}$ & 4.4 & $\begin{array}{l}\text { DNA mismatch repair protein MutL }[2510344175]^{*} \\
\text { Uncharacterized conserved protein }[2510344174]^{*}\end{array}$ & $\begin{array}{l}\text { DNA mismatch repair protein MutL [2514768466]* } \\
\text { Uncharacterized conserved protein [2514768467]* } \\
\text { hypothetical protein [2514768468]hypothetical protein } \\
{[2514768469]}\end{array}$ \\
\hline $\begin{array}{l}\text { ribosomal protein L28 } \\
{[2510342897]}\end{array}$ & ribosomal protein L28 [2514768886] & 4.4 & $\begin{array}{l}\text { ribosomal protein L28 [25103428977* ribosomal } \\
\text { protein L33, bacterial type [2510342896]* }\end{array}$ & $\begin{array}{l}\text { ribosomal protein L28 [2514768886]* ribosomal } \\
\text { protein L33, bacterial type [2514768887]* }\end{array}$ \\
\hline $\begin{array}{c}\text { phosphoribosylglycinamide } \\
\text { formyltransferase, } \\
\text { formyltetrahydrofolate-dependent } \\
{[2510342197]}\end{array}$ & $\begin{array}{c}\text { phosphoribosylglycinamide } \\
\text { formyltransferase, } \\
\text { formyltetrahydrofolate-dependent } \\
\text { [2514768304] }\end{array}$ & 4.4 & $\begin{array}{l}\text { phosphoribosylglycinamide formyltransferase, } \\
\text { formyltetrahydrofolate-dependent [2510342197]* }\end{array}$ & $\begin{array}{l}\text { phosphoribosylglycinamide formyltransferase, } \\
\text { formyltetrahydrofolate-dependent [2514768304]* }\end{array}$ \\
\hline $\begin{array}{l}\text { Bacteriophage tail assembly } \\
\text { protein [2510343979] }\end{array}$ & $\begin{array}{l}\text { Bacteriophage tail assembly protein } \\
\text { [2514768238] }\end{array}$ & 4.4 & $\begin{array}{c}\text { Bacteriophage tail assembly protein } \\
\text { [2510343979]* hypothetical protein [2510343978] } \\
\text { phage portal protein, lambda family } \\
\text { [2510343977]* Protease subunit of ATP-dependent } \\
\text { Clp proteases [2510343976]* }\end{array}$ & $\begin{array}{c}\text { Bacteriophage tail assembly protein [2514768238]* } \\
\text { hypothetical protein [2514768239]phage portal } \\
\text { protein, lambda family }[2514768240] * \text { Protease } \\
\text { subunit of ATP-dependent Clp proteases [2514768241] } \\
*\end{array}$ \\
\hline $\begin{array}{c}\text { acetyl-CoA carboxylase, carboxyl } \\
\text { transferase, beta subunit } \\
{[2510342649]}\end{array}$ & $\begin{array}{c}\text { acetyl-CoA carboxylase, carboxyl } \\
\text { transferase, beta subunit } \\
{[2514769115]}\end{array}$ & 4.4 & $\begin{array}{c}\text { acetyl-CoA carboxylase, carboxyl transferase, beta } \\
\text { subunit }[2510342649]^{*} \text { phosphoglucosamine } \\
\text { mutase }[2510342648]^{*}\end{array}$ & $\begin{array}{c}\text { acetyl-CoA carboxylase, carboxyl transferase, beta } \\
\text { subunit [2514769115]* phosphoglucosamine mutase } \\
{[2514769116]^{*}}\end{array}$ \\
\hline $\begin{array}{l}\text { Single-stranded DNA-binding } \\
\text { protein }[2510343364]\end{array}$ & $\begin{array}{l}\text { Single-stranded DNA-binding protein } \\
{[2514769202]}\end{array}$ & 4.4 & $\begin{array}{c}\text { Single-stranded DNA-binding protein } \\
{[2510343364]^{*} \text { hypothetical protein }} \\
{[2510343363]^{*} \text { Site-specific recombinase XerD }}\end{array}$ & $\begin{array}{l}\text { Single-stranded DNA-binding protein [2514769202]* } \\
\text { hypothetical protein [2514769201]* hypothetical } \\
\text { protein }[2514769200] \text { Site-specific recombinase XerD }\end{array}$ \\
\hline
\end{tabular}




\begin{tabular}{|c|c|c|c|c|}
\hline & & & [2510343362] & [2514769199] \\
\hline $\begin{array}{c}\text { ribosomal protein S1 } \\
{[2510342323]}\end{array}$ & ribosomal protein S1 [2514770073] & 4.5 & ribosomal protein S1 [2510342323]* & ribosomal protein S1 [2514770073]* \\
\hline $\begin{array}{l}\text { Restriction endonuclease S } \\
\text { subunits }[2510344435]\end{array}$ & $\begin{array}{l}\text { Restriction endonuclease S subunits } \\
{[2514770344]}\end{array}$ & 4.5 & $\begin{array}{c}\text { Restriction endonuclease S subunits } \\
{[2510344435]^{*} \text { type I site-specific }} \\
\text { deoxyribonuclease, HsdR family }[2510344434]^{*}\end{array}$ & $\begin{array}{l}\text { Restriction endonuclease } S \text { subunits [2514770344]* } \\
\text { type I site-specific deoxyribonuclease, HsdR family } \\
\text { [2514770343]* Protein of unknown function } \\
\text { (DUF1524). [2514770342] Type I restriction- } \\
\text { modification system methyltransferase subunit } \\
\text { [2514770341]Type I restriction-modification system } \\
\text { methyltransferase subunit [2514770340] Restriction } \\
\text { endonuclease } S \text { subunits [2514770339] Type I site- } \\
\text { specific restriction-modification system, R (restriction) } \\
\text { subunit and related helicases [2514770338] }\end{array}$ \\
\hline $\begin{array}{l}\text { Phosphomannomutase } \\
{[2510341897]}\end{array}$ & Phosphomannomutase [2514768013] & 4.5 & Phosphomannomutase [2510341897]* & Phosphomannomutase [2514768013]* \\
\hline $\begin{array}{l}\text { Nucleoside-diphosphate-sugar } \\
\text { epimerases [2510342219] }\end{array}$ & $\begin{array}{l}\text { Nucleoside-diphosphate-sugar } \\
\text { epimerases [2514768326] }\end{array}$ & 4.5 & $\begin{array}{c}\text { Nucleoside-diphosphate-sugar epimerases } \\
\text { [2510342219]* Glycosyltransferases involved in cell } \\
\text { wall biogenesis }[2510342220]^{*} \text { Predicted } \\
\text { membrane protein }[2510342221]^{*} \text { hypothetical } \\
\text { protein }[2510342222]^{*} \text { hypothetical protein } \\
{[2510342223]^{*}}\end{array}$ & $\begin{array}{c}\text { Nucleoside-diphosphate-sugar epimerases } \\
\text { [2514768326]* Glycosyltransferases involved in cell } \\
\text { wall biogenesis [2514768327]* Predicted membrane } \\
\text { protein [2514768328]* hypothetical protein } \\
{[2514768329]^{*} \text { hypothetical protein [2514768330]* }}\end{array}$ \\
\hline $\begin{array}{l}\text { Adenine specific DNA methylase } \\
\text { Mod [2510343851] }\end{array}$ & $\begin{array}{l}\text { Adenine specific DNA methylase Mod } \\
{[2514769632]}\end{array}$ & 4.5 & $\begin{array}{c}\text { Adenine specific DNA methylase Mod } \\
{[2510343851]^{*} \text { hypothetical protein }} \\
\text { [2510343852]* DNA or RNA helicases of } \\
\text { superfamily II [2510343853]* Predicted hydrolases } \\
\text { or acyltransferases (alpha/beta hydrolase } \\
\text { superfamily) [2510343854]* }\end{array}$ & $\begin{array}{c}\text { Adenine specific DNA methylase Mod [2514769632]* } \\
\text { hypothetical protein [2514769631]* DNA or RNA } \\
\text { helicases of superfamily II [2514769630]* Predicted } \\
\text { hydrolases or acyltransferases (alpha/beta hydrolase } \\
\text { superfamily) [2514769629]* }\end{array}$ \\
\hline $\begin{array}{l}\text { putative addiction module killer } \\
\text { protein [2510342503] }\end{array}$ & $\begin{array}{l}\text { putative addiction module killer } \\
\text { protein [2514769348] }\end{array}$ & 4.5 & $\begin{array}{c}\text { putative addiction module killer protein } \\
\text { [2510342503* probable addiction module antidote } \\
\text { protein [2510342502]* }\end{array}$ & $\begin{array}{l}\text { putative addiction module killer protein [2514769348 }]^{*} \\
\text { probable addiction module antidote protein } \\
{[2514769347]^{*}}\end{array}$ \\
\hline $\begin{array}{c}\text { Succinyl-diaminopimelate } \\
\text { desuccinylase, proteobacterial } \\
\text { clade }[2510341758]\end{array}$ & $\begin{array}{c}\text { succinyl-diaminopimelate } \\
\text { desuccinylase, proteobacterial clade } \\
{[2514767877]}\end{array}$ & 4.5 & $\begin{array}{l}\text { succinyl-diaminopimelate desuccinylase, } \\
\text { proteobacterial clade }[2510341758]^{*}\end{array}$ & $\begin{array}{l}\text { succinyl-diaminopimelate desuccinylase, proteobacterial } \\
\text { clade [2514767877]* }\end{array}$ \\
\hline $\begin{array}{l}\text { Parvulin-like peptidyl-prolyl } \\
\text { isomerase [2510342907] }\end{array}$ & $\begin{array}{c}\text { Parvulin-like peptidyl-prolyl isomerase } \\
{[2514768876]}\end{array}$ & 4.5 & $\begin{array}{l}\text { Parvulin-like peptidyl-prolyl isomerase } \\
{[2510342907]^{*}}\end{array}$ & Parvulin-like peptidyl-prolyl isomerase [2514768876]* \\
\hline tmRNA [2510344423] & tmRNA [2514770331] & 4.5 & $\begin{array}{c}\text { tmRNA }[2510344423]^{*} \text { hypothetical protein } \\
{[2510344422]^{*}}\end{array}$ & $\begin{array}{c}\text { tmRNA }[2514770331]^{*} \text { hypothetical protein } \\
{[2514770330]^{*}}\end{array}$ \\
\hline Beta-galactosidase [2510344105] & Beta-galactosidase [2514768537] & 4.5 & $\begin{array}{l}\text { Beta-galactosidase [2510344105]* hypothetical } \\
\text { protein [2510344106]* }\end{array}$ & $\begin{array}{c}\text { Beta-galactosidase [2514768537]* hypothetical } \\
\text { protein [2514768536]* }\end{array}$ \\
\hline $\begin{array}{l}\text { phage putative head } \\
\text { morphogenesis protein, SPP1 gp7 } \\
\text { family [2510342479] }\end{array}$ & $\begin{array}{l}\text { phage putative head morphogenesis } \\
\text { protein, SPP1 gp7 family } \\
\text { [2514769220] }\end{array}$ & 4.6 & $\begin{array}{c}\text { phage putative head morphogenesis protein, SPP1 } \\
\text { gp7 family [2510342479] * Uncharacterized } \\
\text { protein conserved in bacteria [2510342480] } \\
\text { hypothetical protein [2510342481]* } \\
\text { Uncharacterized protein conserved in bacteria } \\
\text { [2510342482]* }\end{array}$ & $\begin{array}{l}\text { phage putative head morphogenesis protein, SPP1 gp7 } \\
\text { family [2514769220]* Uncharacterized protein } \\
\text { conserved in bacteria [2514769221]* hypothetical } \\
\text { protein [2514769222] * Uncharacterized protein } \\
\text { conserved in bacteria [2514769223] * }\end{array}$ \\
\hline $\begin{array}{l}\text { RND family efflux transporter, MFP } \\
\text { subunit }[2510342371]\end{array}$ & $\begin{array}{l}\text { RND family efflux transporter, MFP } \\
\text { subunit [2514770025] }\end{array}$ & 4.6 & $\begin{array}{l}\text { RND family efflux transporter, MFP subunit } \\
{[2510342371]^{*}}\end{array}$ & $\begin{array}{l}\text { RND family efflux transporter, MFP subunit } \\
{[2514770025]^{*}}\end{array}$ \\
\hline $\begin{array}{l}\text { ATPases involved in chromosome } \\
\text { partitioning [2510343283] }\end{array}$ & $\begin{array}{l}\text { ATPases involved in chromosome } \\
\text { partitioning [2514769940] }\end{array}$ & 4.6 & $\begin{array}{c}\text { ATPases involved in chromosome partitioning } \\
\text { [2510343283]* ParB-like partition proteins } \\
\text { [2510343282]* }\end{array}$ & $\begin{array}{c}\text { ATPases involved in chromosome partitioning } \\
\text { [2514769940]* ParB-like partition proteins } \\
{[2514769939]^{*}}\end{array}$ \\
\hline $\begin{array}{c}\text { glucosamine--fructose-6-phosphate } \\
\text { aminotransferase (isomerizing) } \\
{[2510341780]}\end{array}$ & $\begin{array}{c}\text { glucosamine--fructose-6-phosphate } \\
\text { aminotransferase (isomerizing) } \\
\text { [2514767899] }\end{array}$ & 4.6 & $\begin{array}{l}\text { glucosamine--fructose-6-phosphate } \\
\text { aminotransferase (isomerizing) [2510341780]* }\end{array}$ & $\begin{array}{l}\text { glucosamine--fructose-6-phosphate aminotransferase } \\
\text { (isomerizing) [2514767899]* }\end{array}$ \\
\hline
\end{tabular}




\begin{tabular}{|c|c|c|c|c|}
\hline $\begin{array}{l}\text { phosphoribosylaminoimidazole } \\
\text { synthetase [2510342198] }\end{array}$ & $\begin{array}{l}\text { phosphoribosylaminoimidazole } \\
\text { synthetase [2514768305] }\end{array}$ & 4.6 & $\begin{array}{l}\text { phosphoribosylaminoimidazole synthetase } \\
{[2510342198]^{*}}\end{array}$ & $\begin{array}{l}\text { phosphoribosylaminoimidazole synthetase } \\
{[2514768305]^{*}}\end{array}$ \\
\hline $\begin{array}{l}\text { phage putative head } \\
\text { morphogenesis protein, SPP1 } \mathrm{gp7} \\
\text { family [25103433381] }\end{array}$ & $\begin{array}{l}\text { phage putative head morphogenesis } \\
\text { protein, SPP1 gp7 family } \\
{[2514769220]}\end{array}$ & 4.6 & $\begin{array}{c}\text { phage putative head morphogenesis protein, SPP1 } \\
\text { gp7 family [2510343381]* Uncharacterized } \\
\text { protein conserved in bacteria [2510343382] } \\
\text { hypothetical protein }[2510343383] * \\
\text { Uncharacterized protein conserved in bacteria } \\
{[2510343384] *}\end{array}$ & $\begin{array}{c}\text { phage putative head morphogenesis protein, SPP1 gp } \\
\text { family }[2514769220]^{*} \text { Uncharacterized protein } \\
\text { conserved in bacteria [2514769221]* hypothetical } \\
\text { protein [2514769222]* Uncharacterized protein } \\
\text { conserved in bacteria [2514769223]* }\end{array}$ \\
\hline $\begin{array}{c}\text { Predicted amidohydrolase } \\
{[2510342319]}\end{array}$ & $\begin{array}{c}\text { Predicted amidohydrolase } \\
{[2514770078]}\end{array}$ & 4.6 & Predicted amidohydrolase [2510342319]* & Predicted amidohydrolase [2514770078]* \\
\hline $\begin{array}{l}\text { Protein involved in catabolism of } \\
\text { external DNA [2510341696] }\end{array}$ & $\begin{array}{l}\text { Protein involved in catabolism of } \\
\text { external DNA [2514767811] }\end{array}$ & 4.6 & $\begin{array}{c}\text { Protein involved in catabolism of external DNA } \\
{[2510341696]^{*}}\end{array}$ & $\begin{array}{c}\text { Protein involved in catabolism of external DNA } \\
\text { [2514767811]* }\end{array}$ \\
\hline $\begin{array}{c}\text { GDP-mannose 4,6-dehydratase } \\
{[2510342217]}\end{array}$ & $\begin{array}{c}\text { GDP-mannose 4,6-dehydratase } \\
{[2514768324]}\end{array}$ & 4.6 & $\begin{array}{c}\text { GDP-mannose 4,6-dehydratase [2510342217]* } \\
\text { Nucleoside-diphosphate-sugar epimerases } \\
{[2510342218]^{*}}\end{array}$ & $\begin{array}{c}\text { GDP-mannose 4,6-dehydratase [2514768324]* } \\
\text { Nucleoside-diphosphate-sugar epimerases } \\
\text { [2514768325]* }\end{array}$ \\
\hline Glucokinase [2510342655] & Glucokinase [2514769109] & 4.6 & Glucokinase [2510342655]* & Glucokinase [2514769109]* \\
\hline $\begin{array}{l}\text { Predicted } \mathrm{Zn} \text {-dependent hydrolases } \\
\text { of the beta-lactamase fold } \\
\text { [2510343802] }\end{array}$ & $\begin{array}{c}\text { Predicted Zn-dependent hydrolases of } \\
\text { the beta-lactamase fold } \\
{[2514769682]}\end{array}$ & 4.6 & $\begin{array}{l}\text { Predicted } \mathrm{Zn-dependent} \mathrm{hydrolases} \mathrm{of} \mathrm{the} \mathrm{beta-} \\
\text { lactamase fold [2510343802]* }\end{array}$ & $\begin{array}{l}\text { Predicted } \mathrm{Zn} \text {-dependent hydrolases of the beta- } \\
\text { lactamase fold [2514769682]* }\end{array}$ \\
\hline $\begin{array}{l}\text { Predicted Zn-dependent peptidases } \\
{[2510344126]}\end{array}$ & $\begin{array}{l}\text { Predicted Zn-dependent peptidases } \\
{[2514768516]}\end{array}$ & 4.6 & Predicted $\mathrm{Zn}$-dependent peptidases [2510344126]* & Predicted Zn-dependent peptidases [2514768516]* \\
\hline $\begin{array}{l}\text { tyrosyl-tRNA synthetase } \\
{[2510341805]}\end{array}$ & $\begin{array}{l}\text { tyrosyl-tRNA synthetase } \\
{[2514767924]}\end{array}$ & 4.6 & tyrosyl-tRNA synthetase [2510341805]* & tyrosyl-tRNA synthetase [2514767924]* \\
\hline $\begin{array}{l}\text { phage putative head } \\
\text { morphogenesis protein, SPP1 gp7 } \\
\text { family [2510343381] }\end{array}$ & $\begin{array}{l}\text { phage putative head morphogenesis } \\
\text { protein, SPP1 gp7 family } \\
\text { [2514769323] }\end{array}$ & 4.6 & $\begin{array}{c}\text { phage putative head morphogenesis protein, SPP1 } \\
\text { gp7 family [2510343381]* Uncharacterized } \\
\text { protein conserved in bacteria [2510343382]* } \\
\text { hypothetical protein [2510343383]* } \\
\text { Uncharacterized protein conserved in bacteria } \\
{[2510343384]^{*}} \\
\end{array}$ & $\begin{array}{c}\text { phage putative head morphogenesis protein, SPP1 gp } \\
\text { family [2514769323]* Uncharacterized protein } \\
\text { conserved in bacteria [2514769324]* hypothetical } \\
\text { proten [2514769325** Uncharacterized protein } \\
\text { conserved in bacteria }[2514769326]^{*}\end{array}$ \\
\hline $\begin{array}{l}\text { phage putative head } \\
\text { morphogenesis protein, SPP1 } \mathrm{gp} 7 \\
\text { family [2510342479] }\end{array}$ & $\begin{array}{l}\text { phage putative head morphogenesis } \\
\text { protein, SPP1 } 1 \text { gp7 family } \\
{[2514769323]}\end{array}$ & 4.6 & $\begin{array}{c}\text { phage putative head morphogenesis protein, SPP1 } \\
\text { gp7 family [2510342477]* Uncharacterized } \\
\text { protein conserved in bacteria [2510342480]* } \\
\text { hypothetical protein [2510342481]* } \\
\text { Uncharacterized protein conserved in bacteria } \\
{[2510342482]^{*}}\end{array}$ & $\begin{array}{l}\text { phage putative head morphogenesis protein, SPP1 gp } \\
\text { family }[2514769323] * \text { Uncharacterized protein } \\
\text { conserved in bacteria [2514769324]* hypothetical } \\
\text { protein [2514769325]* Uncharacterized protein } \\
\text { conserved in bacteria [2514769326] }\end{array}$ \\
\hline $\begin{array}{l}\text { Membrane proteins related to } \\
\text { metalloendopeptidases } \\
{[2510341804]}\end{array}$ & $\begin{array}{l}\text { Membrane proteins related to } \\
\text { metalloendopeptidases } \\
{[2514767923]}\end{array}$ & 4.6 & $\begin{array}{c}\text { Membrane proteins related to } \\
\text { metalloendopeptidases [2510341804]* }\end{array}$ & $\begin{array}{l}\text { Membrane proteins related to metalloendopeptidases } \\
{[2514767923]^{*}}\end{array}$ \\
\hline $\begin{array}{l}\text { Predicted esterase of the alpha- } \\
\text { beta hydrolase superfamily } \\
{[2510341710]}\end{array}$ & $\begin{array}{l}\text { Predicted esterase of the alpha-beta } \\
\text { hydrolase superfamily [2514767827] }\end{array}$ & 4.6 & $\begin{array}{c}\text { Predicted esterase of the alpha-beta hydrolase } \\
\text { superfamily [2510341710 }]^{*}\end{array}$ & $\begin{array}{c}\text { Predicted esterase of the alpha-beta hydrolase } \\
\text { superfamily [2514767827]* }\end{array}$ \\
\hline $\begin{array}{l}\text { 7-cyano-7-deazaguanine reductase } \\
{[2510342372]}\end{array}$ & $\begin{array}{c}\text { 7-cyano-7-deazaguanine reductase } \\
{[2514770024]}\end{array}$ & 4.6 & 7-cyano-7-deazaguanine reductase [2510342372]* & 7-cyano-7-deazaguanine reductase $[2514770024] *$ \\
\hline $\begin{array}{l}\text { 6-phosphogluconate dehydratase } \\
{[2510343029]}\end{array}$ & $\begin{array}{l}\text { 6-phosphogluconate dehydratase } \\
{[2514768756]}\end{array}$ & 4.7 & 6-phosphogluconate dehydratase [2510343029]* & 6-phosphogluconate dehydratase [2514768756]* \\
\hline protein RecA [2510341764] & protein RecA [2514767883] & 4.7 & protein RecA [2510341764]* & protein RecA [2514767883]* \\
\hline $\begin{array}{c}\text { phosphomethylpyrimidine kinase } \\
{[2510342229]}\end{array}$ & $\begin{array}{c}\text { phosphomethylpyrimidine kinase } \\
{[2514768335]}\end{array}$ & 4.7 & phosphomethylpyrimidine kinase [2510342229]* & phosphomethylpyrimidine kinase [2514768335]* \\
\hline $\begin{array}{l}\text { type I restriction system adenine } \\
\text { methylase (hsdM) [2510344437] }\end{array}$ & $\begin{array}{l}\text { type I restriction system adenine } \\
\text { methylase }(\mathrm{hsdM})[2514770346]\end{array}$ & 4.7 & $\begin{array}{c}\text { type I restriction system adenine methylase (hsdM) } \\
\text { [2510344437]* hypothetical protein } \\
{[2510344436]^{*}}\end{array}$ & $\begin{array}{l}\text { type I restriction system adenine methylase (hsdM) } \\
\text { [2514770346]* hypothetical protein [2514770345]* }\end{array}$ \\
\hline
\end{tabular}




\begin{tabular}{|c|c|c|c|c|}
\hline $\begin{array}{c}\text { His Kinase A (phosphoacceptor) } \\
\text { domain./Histidine kinase-, DNA } \\
\text { gyrase B-, and HSP90-like ATPase. } \\
\text { [2510344272] }\end{array}$ & $\begin{array}{c}\text { His Kinase A (phosphoacceptor) } \\
\text { domain./Histidine kinase-, DNA } \\
\text { gyrase B-, and HSP90-like ATPase. } \\
\text { [2514770183] }\end{array}$ & 4.7 & $\begin{array}{c}\text { His Kinase A (phosphoacceptor) domain./Histidine } \\
\text { kinase-, DNA gyrase B-, and HSP90-like ATPase. } \\
\text { [2510344272] }\end{array}$ & $\begin{array}{c}\text { His Kinase A (phosphoacceptor) domain./Histidine } \\
\text { kinase-, DNA gyrase B-, and HSP90-like ATPase. } \\
\text { [2514770183]* }\end{array}$ \\
\hline $\begin{array}{l}\text { Type II secretory pathway, } \\
\text { component PulF [2510344264] }\end{array}$ & $\begin{array}{l}\text { Type II secretory pathway, } \\
\text { component PulF [2514770175] }\end{array}$ & 4.7 & $\begin{array}{c}\text { Type II secretory pathway, component PulF } \\
\text { [2510344264]* Type II secretory pathway, prepilin } \\
\text { signal peptidase PulO and related peptidases } \\
{[2510344263]^{*} \text { dephospho-CoA kinase }} \\
\text { [2510344262]* }\end{array}$ & $\begin{array}{c}\text { Type II secretory pathway, component PulF } \\
\text { [2514770175]* Type II secretory pathway, prepilin } \\
\text { signal peptidase PulO and related peptidases } \\
\text { [2514770174]* dephospho-CoA kinase [2514770173]* }\end{array}$ \\
\hline $\begin{array}{l}\text { type IV-A pilus assembly ATPase } \\
\text { PilB [2510344270] }\end{array}$ & $\begin{array}{l}\text { type IV-A pilus assembly ATPase PilB } \\
{[2514770181]}\end{array}$ & 4.7 & $\begin{array}{l}\text { type IV-A pilus assembly ATPase PilB } \\
{[2510344270]^{*}}\end{array}$ & type IV-A pilus assembly ATPase PilB [2514770181]* \\
\hline $\begin{array}{c}\text { prepilin-type N-terminal } \\
\text { cleavage/methylation domain } \\
{[2510344265]}\end{array}$ & $\begin{array}{c}\text { prepilin-type } \mathrm{N} \text {-terminal } \\
\text { cleavage/methylation domain } \\
{[2514770176]}\end{array}$ & 4.7 & $\begin{array}{l}\text { prepilin-type N-terminal cleavage/methylation } \\
\text { domain }[2510344265]^{*}\end{array}$ & $\begin{array}{c}\text { prepilin-type N-terminal cleavage/methylation domain } \\
{[2514770176]^{*}}\end{array}$ \\
\hline $\begin{array}{l}\text { Uncharacterized protein conserved } \\
\text { in bacteria [2510342199] }\end{array}$ & $\begin{array}{l}\text { Uncharacterized protein conserved in } \\
\text { bacteria }[2514768306]\end{array}$ & 4.7 & $\begin{array}{c}\text { Uncharacterized protein conserved in bacteria } \\
{[2510342199]^{*} \text { Predicted permease }} \\
\text { [2510342200]* DnaA regulatory inactivator Hda } \\
{[2510342201]^{*}} \\
\end{array}$ & $\begin{array}{l}\text { Uncharacterized protein conserved in bacteria } \\
\text { [2514768306]* Predicted permease [2514768307]* } \\
\text { DnaA regulatory inactivator Hda [2514768308]* }\end{array}$ \\
\hline $\begin{array}{l}\text { methionyl-tRNA synthetase } \\
{[2510342168]}\end{array}$ & $\begin{array}{c}\text { methionyl-tRNA } \\
\text { synthetase/methionyl-tRNA } \\
\text { synthetase C-terminal region/beta } \\
\text { chain [2514768275] }\end{array}$ & 4.7 & $\begin{array}{c}\text { methionyl-tRNA synthetase }[2510342168]^{*} \\
\text { methionyl-tRNA synthetase C-terminal region/beta } \\
\text { chain }[2510342167]\end{array}$ & $\begin{array}{l}\text { methionyl-tRNA synthetase/methionyl-tRNA synthetase } \\
\text { C-terminal region/beta chain }[2514768275]^{*}\end{array}$ \\
\hline $\begin{array}{l}\text { Uncharacterized protein conserved } \\
\text { in bacteria [2510344473] }\end{array}$ & $\begin{array}{l}\text { Uncharacterized protein conserved in } \\
\text { bacteria }[2514770384]\end{array}$ & 4.7 & $\begin{array}{c}\text { Uncharacterized protein conserved in bacteria } \\
\text { [2510344473]* probable addiction module antidote } \\
\text { protein [2510344472]* }\end{array}$ & $\begin{array}{c}\text { Uncharacterized protein conserved in bacteria } \\
\text { [2514770384]* probable addiction module antidote } \\
\text { protein [2514770383]* }\end{array}$ \\
\hline $\begin{array}{l}\text { alpha-1,2-mannosidase, putative } \\
{[2510344104]}\end{array}$ & $\begin{array}{c}\text { alpha-1,2-mannosidase, putative } \\
{[2514768538]}\end{array}$ & 4.8 & alpha-1,2-mannosidase, putative [2510344104]* & alpha-1,2-mannosidase, putative [2514768538]* \\
\hline $\begin{array}{c}\text { Cation/multidrug efflux pump } \\
{[2510342369]}\end{array}$ & $\begin{array}{c}\text { Cation/multidrug efflux pump } \\
{[2514770027]}\end{array}$ & 4.8 & Cation/multidrug efflux pump [2510342369]* & Cation/multidrug efflux pump [2514770027]* \\
\hline $\begin{array}{l}\text { 3-deoxy-8-phosphooctulonate } \\
\text { synthase [2510342819] }\end{array}$ & $\begin{array}{l}\text { 3-deoxy-8-phosphooctulonate } \\
\text { synthase [2514768953] }\end{array}$ & 4.8 & $\begin{array}{l}\text { 3-deoxy-8-phosphooctulonate synthase } \\
{[2510342819]^{*}}\end{array}$ & $\begin{array}{l}\text { 3-deoxy-8-phosphooctulonate synthase } \\
{[2514768953]^{*}}\end{array}$ \\
\hline $\begin{array}{l}\text { Bacteriophage terminase large } \\
\text { (ATPase) subunit and inactivated } \\
\text { derivatives [2510342854] }\end{array}$ & $\begin{array}{l}\text { Bacteriophage terminase large } \\
\text { (ATPase) subunit and inactivated } \\
\text { derivatives [2514768915] }\end{array}$ & 4.8 & $\begin{array}{l}\text { Bacteriophage terminase large (ATPase) subunit } \\
\text { and inactivated derivatives [2510342854]* }\end{array}$ & $\begin{array}{c}\text { Bacteriophage terminase large (ATPase) subunit and } \\
\text { inactivated derivatives [2514768915]* }\end{array}$ \\
\hline $\begin{array}{l}\text { Entner-Doudoroff aldolase } \\
\text { [2510343030] }\end{array}$ & $\begin{array}{c}\text { Entner-Doudoroff aldolase } \\
{[2514768755]}\end{array}$ & 4.8 & Entner-Doudoroff aldolase [2510343030]* & Entner-Doudoroff aldolase [2514768755]* \\
\hline $\begin{array}{l}\text { S-methyl-5-thioribose-1-phosphate } \\
\text { isomerase [2510344279] }\end{array}$ & $\begin{array}{l}\text { S-methyl-5-thioribose-1-phosphate } \\
\text { isomerase [2514770190] }\end{array}$ & 4.8 & $\begin{array}{c}\text { S-methyl-5-thioribose-1-phosphate isomerase } \\
{[2510344279]^{*}}\end{array}$ & $\begin{array}{c}\text { S-methyl-5-thioribose-1-phosphate isomerase } \\
{[2514770190]^{*}}\end{array}$ \\
\hline $\begin{array}{l}\text { glycyl-tRNA synthetase, tetrameric } \\
\text { type, alpha subunit [2510343857] }\end{array}$ & $\begin{array}{l}\text { glycyl-tRNA synthetase, tetrameric } \\
\text { type, alpha subunit }[2514769625]\end{array}$ & 4.8 & $\begin{array}{c}\text { glycyl-tRNA synthetase, tetrameric type, alpha } \\
\text { subunit [2510343857]* }\end{array}$ & $\begin{array}{l}\text { glycyl-tRNA synthetase, tetrameric type, alpha subunit } \\
{[2514769625]^{*}}\end{array}$ \\
\hline $\begin{array}{l}\text { Predicted periplasmic ligand- } \\
\text { binding sensor domain } \\
{[2510342775]}\end{array}$ & $\begin{array}{l}\text { Predicted periplasmic ligand-binding } \\
\text { sensor domain [2514768993] }\end{array}$ & 4.8 & $\begin{array}{l}\text { Predicted periplasmic ligand-binding sensor domain } \\
{[2510342775]^{*}}\end{array}$ & $\begin{array}{l}\text { Predicted periplasmic ligand-binding sensor domain } \\
{[2514768993]^{*}}\end{array}$ \\
\hline $\begin{array}{l}\text { asparagine synthase (glutamine- } \\
\text { hydrolyzing) [2510341759] }\end{array}$ & $\begin{array}{l}\text { asparagine synthase (glutamine- } \\
\text { hydrolyzing) [2514767878] }\end{array}$ & 4.8 & $\begin{array}{l}\text { asparagine synthase (glutamine-hydrolyzing) } \\
{[2510341759]^{*}}\end{array}$ & $\begin{array}{l}\text { asparagine synthase (glutamine-hydrolyzing) } \\
{[2514767878]^{*}}\end{array}$ \\
\hline $\begin{array}{l}\text { Phage-related protein } \\
\text { [2510342478] }\end{array}$ & Phage-related protein [2514769322] & 4.8 & $\begin{array}{l}\text { Phage-related protein [2510342478]* } \\
\text { Uncharacterized conserved small protein } \\
{[2510342477]^{*}}\end{array}$ & $\begin{array}{l}\text { Phage-related protein }[2514769322] * \text { Uncharacterized } \\
\text { conserved small protein }[2514769321] *\end{array}$ \\
\hline $\begin{array}{l}\text { succinate dehydrogenase, } \\
\text { cytochrome b556 subunit } \\
{[2510343022]}\end{array}$ & $\begin{array}{l}\text { succinate dehydrogenase, cytochrome } \\
\text { b556 subunit [2514768763] }\end{array}$ & 4.8 & $\begin{array}{l}\text { succinate dehydrogenase, cytochrome b556 subunit } \\
\text { [2510343022] succinate dehydrogenase, } \\
\text { hydrophobic membrane anchor protein } \\
\text { [2510343021]* succinate dehydrogenase, } \\
\text { flavoprotein subunit, E. coli//mitochondrial subgroup } \\
\text { [2510343020]* succinate dehydrogenase and } \\
\text { fumarate reductase iron-sulfur protein }\end{array}$ & $\begin{array}{c}\text { succinate dehydrogenase, cytochrome b556 subunit } \\
\text { [2514768763]* succinate dehydrogenase, hydrophobic } \\
\text { membrane anchor protein [25147668764]* succinate } \\
\text { dehydrogenase, flavoprotein subunit, E. } \\
\text { coli/mitochondrial subgroup [2514768765]* succinate } \\
\text { dehydrogenase and fumarate reductase iron-sulfur } \\
\text { protein }[2514768766]^{*}\end{array}$ \\
\hline
\end{tabular}




\begin{tabular}{|c|c|c|c|c|}
\hline & & & [2510343019]* & \\
\hline $\begin{array}{l}\text { glucose/galactose transporter } \\
\text { [2510343412] }\end{array}$ & $\begin{array}{c}\text { L-fucose: } \mathrm{H}+\text { symporter permease } \\
{[2514769254]}\end{array}$ & 4.8 & $\begin{array}{c}\text { glucose/galactose transporter [2510343412]* } \\
\text { Sugar kinases, ribokinase family [2510343413]* } \mathrm{N} \text { - } \\
\text { acyl-D-glucosamine 2-epimerase [2510343414]* }\end{array}$ & $\begin{array}{l}\text { L-fucose: } \mathrm{H}+\text { symporter permease }[2514769254]^{*} \\
\text { Sugar kinases, ribokinase family }[2514769255]]^{*} \mathrm{~N} \text { - } \\
\text { acyl-D-glucosamine 2-epimerase }[2514769256]]^{*}\end{array}$ \\
\hline $\begin{array}{l}\text { Acyl-CoA synthetases (AMP- } \\
\text { forming)//MP-acid ligases II } \\
\text { [2510343277] }\end{array}$ & $\begin{array}{c}\text { Acyl-CoA synthetases (AMP- } \\
\text { forming)/AMP-acid ligases II } \\
{[2514769934]}\end{array}$ & 4.8 & $\begin{array}{l}\text { Acyl-CoA synthetases (AMP-forming)/AMP-acid } \\
\text { ligases II [2510343277]* }\end{array}$ & $\begin{array}{l}\text { Acyl-CoA synthetases (AMP-forming)/AMP-acid ligases } \\
\text { II [2514769934]* }\end{array}$ \\
\hline $\begin{array}{l}\text { Phage-related protein } \\
\text { [2510343380] }\end{array}$ & Phage-related protein [2514769322] & 4.8 & $\begin{array}{l}\text { Phage-related protein }[2510343380]^{*} \\
\text { Uncharacterized conserved small protein } \\
{[2510343379]^{*}}\end{array}$ & $\begin{array}{c}\text { Phage-related protein [2514769322]* Uncharacterized } \\
\text { conserved small protein [2514769321]* }\end{array}$ \\
\hline $\begin{array}{c}\text { Site-specific DNA methylase } \\
{[2510343547]}\end{array}$ & $\begin{array}{c}\text { Site-specific DNA methylase } \\
{[2514769462]}\end{array}$ & 4.8 & Site-specific DNA methylase [2510343547]* & Site-specific DNA methylase [2514769462]* \\
\hline $\begin{array}{c}\text { glutaminyl-tRNA synthetase } \\
{[2510342770]}\end{array}$ & $\begin{array}{c}\text { glutaminyl-tRNA synthetase } \\
{[2514768999]}\end{array}$ & 4.8 & glutaminyl-tRNA synthetase [2510342770]* & glutaminyl-tRNA synthetase [2514768999]* \\
\hline $\begin{array}{l}\text { Response regulator containing } \\
\text { CheY-like receiver, AAA-type } \\
\text { ATPase, and DNA-binding domains } \\
{[2510344271]}\end{array}$ & $\begin{array}{l}\text { Response regulator containing CheY- } \\
\text { like receiver, AAA-type ATPase, and } \\
\text { DNA-binding domains [2514770182] }\end{array}$ & 4.8 & $\begin{array}{l}\text { Response regulator containing CheY-like receiver, } \\
\text { AAA-type ATPase, and DNA-binding domains } \\
\text { [2510344271]* }\end{array}$ & $\begin{array}{l}\text { Response regulator containing CheY-like receiver, AAA- } \\
\text { type ATPase, and DNA-binding domains } \\
\text { [2514770182]* }\end{array}$ \\
\hline $\begin{array}{l}\text { DNA polymerase III, beta subunit } \\
{[2510341661]}\end{array}$ & $\begin{array}{l}\text { DNA polymerase III, beta subunit } \\
{[2514767778]}\end{array}$ & 4.8 & DNA polymerase III, beta subunit [2510341661]* & DNA polymerase III, beta subunit [2514767778]* \\
\hline $\begin{array}{c}\mathrm{N} \text {-acetyl-beta-hexosaminidase } \\
{[2510344099]}\end{array}$ & $\begin{array}{l}\mathrm{N} \text {-acetyl-beta-hexosaminidase } \\
{[2514768543]}\end{array}$ & 4.8 & $\begin{array}{c}\mathrm{N} \text {-acetyl-beta-hexosaminidase [2510344099]* } \\
\text { Beta-galactosidase/beta-glucuronidase } \\
{[2510344100]^{*}}\end{array}$ & $\begin{array}{l}\text { N-acetyl-beta-hexosaminidase [25147685433* Beta- } \\
\text { galactosidase/beta-glucuronidase [2514768542]* }\end{array}$ \\
\hline $\begin{array}{l}\text { Phage-related protein } \\
{[2510342478]}\end{array}$ & Phage-related protein [2514769219] & 4.8 & $\begin{array}{c}\text { Phage-related protein [2510342478]* } \\
\text { Uncharacterized conserved small protein } \\
{[2510342477] *}\end{array}$ & $\begin{array}{c}\text { Phage-related protein }[2514769219] * \text { Uncharacterized } \\
\text { conserved small protein [2514769218] * }\end{array}$ \\
\hline $\begin{array}{l}\text { Prophage antirepressor } \\
{[2510342466]}\end{array}$ & $\begin{array}{l}\text { Prophage antirepressor } \\
{[2514770141]}\end{array}$ & 4.8 & Prophage antirepressor [2510342466]* & Prophage antirepressor [2514770141]* \\
\hline glycerol kinase [2510343269] & glycerol kinase [2514769927] & 4.8 & glycerol kinase [2510343269]* & glycerol kinase [2514769927]* \\
\hline $\begin{array}{l}\text { Undecaprenyl-phosphate glucose } \\
\text { phosphotransferase [2510342381] }\end{array}$ & $\begin{array}{l}\text { Undecaprenyl-phosphate glucose } \\
\text { phosphotransferase [2514770014] }\end{array}$ & 4.8 & $\begin{array}{c}\text { Undecaprenyl-phosphate glucose } \\
\text { phosphotransferase }[2510342381]^{*} \text { hypothetical } \\
\text { protein }[2510342382]^{*} \text { Fucose } 4 \text {-O-acetylase and } \\
\text { related acetyltransferases [2510342383]* }\end{array}$ & $\begin{array}{c}\text { Undecaprenyl-phosphate glucose phosphotransferase } \\
{[2514770014]^{*} \text { hypothetical protein }[2514770013]^{*}} \\
\text { Fucose 4-0-acetylase and related acetyltransferases } \\
{[2514770012]^{*}}\end{array}$ \\
\hline $\begin{array}{l}\text { Phage-related protein } \\
{[2510343380]}\end{array}$ & Phage-related protein [2514769219] & 4.8 & $\begin{array}{c}\text { Phage-related protein }[2510343380]^{*} \\
\text { Uncharacterized conserved small protein } \\
{[2510343379] *}\end{array}$ & $\begin{array}{c}\text { Phage-related protein [2514769219]* Uncharacterized } \\
\text { conserved small protein [2514769218]* }\end{array}$ \\
\hline $\begin{array}{l}\text { ATPase related to the helicase } \\
\text { subunit of the Holliday junction } \\
\text { resolvase [2510342663] }\end{array}$ & $\begin{array}{l}\text { ATPase related to the helicase subunit } \\
\text { of the Holliday junction resolvase } \\
{[2514769101]}\end{array}$ & 4.8 & $\begin{array}{l}\text { ATPase related to the helicase subunit of the } \\
\text { Holliday junction resolvase }[2510342663]^{*}\end{array}$ & $\begin{array}{l}\text { ATPase related to the helicase subunit of the Holliday } \\
\text { junction resolvase }[2514769101]^{*}\end{array}$ \\
\hline $\begin{array}{l}\text { UDP-N-acetylmuramate:L-alanyl- } \\
\text { gamma-D-glutamyl-meso- } \\
\text { diaminopimelate ligase } \\
\text { [2510341909] }\end{array}$ & $\begin{array}{l}\text { UDP-N-acetylmuramate:L-alanyl- } \\
\text { gamma-D-glutamyl-meso- } \\
\text { diaminopimelate ligase } \\
\text { [2514768024] }\end{array}$ & 4.8 & $\begin{array}{l}\text { UDP-N-acetylmuramate:L-alanyl-gamma-D- } \\
\text { glutamyl-meso-diaminopimelate ligase } \\
\text { [2510341909]* }\end{array}$ & $\begin{array}{l}\text { UDP-N-acetylmuramate:L-alanyl-gamma-D-glutamyl- } \\
\text { meso-diaminopimelate ligase }[2514768024]^{*}\end{array}$ \\
\hline $\begin{array}{l}\text { Putative threonine efflux protein } \\
{[2510344439]}\end{array}$ & $\begin{array}{l}\text { Putative threonine efflux protein } \\
{[2514770348]}\end{array}$ & 4.8 & Putative threonine efflux protein [2510344439]* & Putative threonine efflux protein [2514770348]* \\
\hline $\begin{array}{l}\text { histidyl-tRNA synthetase } \\
{[2510343230]}\end{array}$ & $\begin{array}{l}\text { histidyl-tRNA synthetase } \\
{[2514769889]}\end{array}$ & 4.8 & histidyl-tRNA synthetase $[2510343230]^{*}$ & histidyl-tRNA synthetase [2514769889]* \\
\hline $\begin{array}{l}\text { Integral membrane protein } \\
\text { possibly involved in chromosome } \\
\text { condensation [2510342662] }\end{array}$ & $\begin{array}{l}\text { Integral membrane protein possibly } \\
\text { involved in chromosome condensation } \\
{[2514769102]}\end{array}$ & 4.8 & $\begin{array}{l}\text { Integral membrane protein possibly involved in } \\
\text { chromosome condensation [2510342662]* } \\
\text { hypothetical protein }[2510342661]^{*}\end{array}$ & $\begin{array}{c}\text { Integral membrane protein possibly involved in } \\
\text { chromosome condensation [2514769102]* } \\
\text { hypothetical protein }[2514769103]^{*}\end{array}$ \\
\hline $\begin{array}{l}\text { Plasmid maintenance system killer } \\
\text { protein [2510344208] }\end{array}$ & $\begin{array}{l}\text { Plasmid maintenance system killer } \\
\text { protein [2514768433] }\end{array}$ & 4.8 & $\begin{array}{c}\text { Plasmid maintenance system killer protein } \\
{[2510344208]^{*} \text { addiction module antidote protein, }}\end{array}$ & $\begin{array}{c}\text { Plasmid maintenance system killer protein } \\
\text { [2514768433]* addiction module antidote protein, HigA }\end{array}$ \\
\hline
\end{tabular}




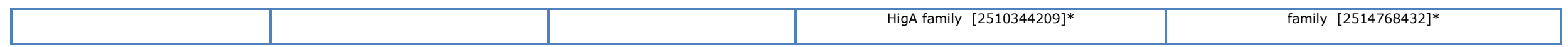

Anexo 3: Distribuição de genes cI nos cromossomos de diferentes cepas de $X$. fastidiosa, cujas sequências estão publicamente disponíveis ou que foram recém sequenciadas pelo grupo da profa. Dra. Aline Maria da Silva (Pierry, 2012: Santana, 2013) (cepas com asteriscos sobrescritos). A identificação de ortólogos foi realizada diretamente na plataforma IMG-ER do DOE JGI, utilizando-se como referência a sequência de aminoácidos do gene XFJ1 00020160 da cepa J1a12, anotado como repressor diretamente na plataforma IMG-ER do DOE JGI, utilizando-se como referência a sequência de aminoácidos do gene XFJ1_00020160 da cepa J1a12, anotado como repressor
transcricional relacionado a bacteriófago. Genes com identidade igual ou superior a $40 \%$ e cujas sequências apresentaram os dois motivos encontrados em cI de $E$. coli transcricional relacionado a bacteriófago. Genes com identidade igual ou superior a $40 \%$ e cujas sequências apresentaram os dois motivos encontrados em cI de $E$. coli
(peptidase e hélice-volta-hélice) foram considerados ortólogos intactos. Genes que satisfizeram todas as condições, mas que não apresentaram nas suas sequências o motivo de hélice-volta-hélice foram considerados ortólogos corrompidos. Genes que satisfizeram todas as condições, mas que não apresentaram nas suas sequências o motivo de peptidase não foram detectados.

\begin{tabular}{|c|c|c|c|}
\hline Cepas & $\begin{array}{c}\text { Hospedeiro de } \\
\text { isolamento }\end{array}$ & $\begin{array}{c}\text { Número de genes cI } \\
\text { intactos }\end{array}$ & $\begin{array}{c}\text { Número de genes } \\
\text { cI corrompidos }\end{array}$ \\
\hline Ann1 & $\begin{array}{c}\text { Espirradeira } \\
\text { (Bhattacharyya et al., } \\
\text { 2002b) }\end{array}$ & 0 & 0 \\
\hline Dixon & $\begin{array}{c}\text { Amendoeira } \\
\text { (Bhattacharyya et al., } \\
2002 b)\end{array}$ & 2 & 1 \\
\hline 9a5c & $\begin{array}{c}\text { Citros (Simpson et al., } \\
2000)\end{array}$ & 1 & 1 \\
\hline U24d* & Citros & 2 & 1 \\
\hline J1a12* & Citros & 0 & 1 \\
\hline Temecula1 & Videira (Van Sluys et & 1 & 1 \\
\hline
\end{tabular}




\begin{tabular}{|c|c|c|c|}
\hline M12 & $\begin{array}{c}\text { Amendoeira (Chen et } \\
\text { al., 2010) }\end{array}$ & 0 & 2 \\
\hline M23 & $\begin{array}{c}\text { Amendoeira(Chen et al., } \\
\text { 2010) }\end{array}$ & 0 & 1 \\
\hline Pr8x* & Ameixeira & 0 & 0 \\
\hline Hib4* & Hibisco & 0 & 1 \\
\hline 3124* & Cafeeiro & 0 & 1 \\
\hline GB514 & Videira (Schreiber, & 0 & 1 \\
\hline Fb7* & Citros & 1 & 1 \\
\hline EB92-1 & Sabugueiro do Canadá \\
& (Zhang et al., 2011) & 0 & 1 \\
\hline
\end{tabular}




\section{Súmula curricular}

\section{Fernando Domingues Kümmel Tria}

Nascimento: 27/04/1987

São Paulo, SP, Brasil

Contato: fernandotria@yahoo.com.br

\section{Formação acadêmica}

$2010-2013$

Mestrado em Bioinformática

2006 - 2009

Bacharelado em

Biotecnologia

\section{Formação complementar}

2012

Palestrante

2009

Estágio
USP - Universidade de São Paulo

Instituto de Matemática e Estatística

Programa de Pós-Graduação Interunidades em Bioinformática

São Paulo, SP, Brasil

Orientação: Dra. Aline Maria da Silva

Bolsista FAPESP

UFSCar - Universidade Federal de São Carlos

Centro de Ciências Agrárias

Araras, SP, Brasil

USP - Universidade de São Paulo

Instituto de Matemática e Estatística

II Workshop of Bioinformatics

São Paulo, SP, Brasil

Palestra intitulada "In silico analysis of promoter sequences in Xylella fastidiosa"

USP - Universidade de São Paulo

Departamento de Engenharia Bioquímica

São Paulo, SP, Brasil

Orientação: Dra. Beatriz Vahan Kilikian

"Fermentação em estado sólido para produção de celulases e xilanases utilizando bagaço de cana-de-açúcar como fonte de carbono" 